$$
\text { DOE/RL-91-50-Rev. } 2
$$

DOE/RL-91-50

Rev. 2

UC-900

\title{
Environmental Monitoring Plan United States Department of Energy Richland Operations Office
}

November 10, 1997

Prepared by personnel from

Pacific Northwest National Laboratory,

Fluor Daniel Hanford, Inc. and its subcontractor

Waste Management Federal Services of

Hanford, Inc., and Bechtel Hanford, Inc., for

the U.S. Department of Energy

under Contract DE-AC06-76RLO 1830

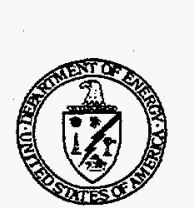

\section{United States}

\section{Department of Energy}

P.O. Box 550

Richland, Washington 99352

Approved for Public Release 


\section{LEGAL DISCLAIMER}

This report was prepared as an account of work sponsored by an agency of the United States Government. Neither the United States. Government nor any agency thereof, nor any of their employees, nor any of their contractors, subcontractors or their employees, makes any warranty, express or implied, or assumes any legal liability or responsibility for the accuracy, completeness, or any third party's use or the results of such use of any information, apparatus, product, or process disclosed, or represents that its use would not infringe privately owned rights. Reference herein to any specific commercial product, process, or service by trade name, trademark, manufacturer, or otherwise, does not necessarily constitute or imply its endorsement, recommendation, or favoring by the United States Government or any agency thereof or its contractors or subcontractors. The views and opinions of authors expressed herein do not necessarily state or reflect those of the United States Government or any agency thereof.

This report has been reproduced from the best available copy. Available in paper copy and microfiche.

Available to the U.S. Department of Energy and its contractors from

Office of Scientific and Technical Information

P.O. Box 62

Oak Ridge, TN 37831

(615) 576-8401

Available to the public from the U.S. Department of Commerce National Technical Information Service

5285 Port Royal Road

Springfield, VA 22161

(703) 487-4650

Printed in the United States of America

DISCLM-1.CHP (1-91) 


\section{DISCLAIMER}

Portions of this document may be illegible electronic image products. Images are produced from the best available original document. 


\section{Preface}

This Environmental Monitoring Plan was prepared for the U.S. Department of Energy's (DOE's) Richland Operations Office (RL) to implement the requirements of DOE Order 5400.1. According to the Order, each DOE site, facility, or activity that uses, generates, releases, or manages significant pollutants or hazardous materials shall prepare a written environmental monitoring plan covering two major activities: 1) effluent monitoring and 2) environmental surveillance. The plan is to contain information discussing the rationale and design criteria for the monitoring programs, sampling locations and schedules, quality assurance requirements, program implementation procedures, analytical procedures, and reporting requirements. The plan's purpose is to assist DOE in the management of environmental activities at the Hanford Site and to help ensure that operations on the site are conducted in an environmentally safe and sound manner.

This plan was prepared by personnel from Pacific Northwest National Laboratory, Fluor Daniel Hanford, Inc. and its subcontractor Waste Management Federal Services of Hanford, Inc., and Bechtel Hanford, Inc. Document production was coordinated for DOE-RL's Environmental Assurance, Permits and Policy Division by the Pacific Northwest National Laboratory's Public Safety and Resource Protection Program. Pacific Northwest National Laboratory is operated for DOE by Battelle.

Both hard-copy and electronic versions of this plan have been produced. The hard-copy version is available for review at the DOE Public Reading Room in Richland, Washington. The electronic version is available on the internet at http://www.hanford.gov/docs/rl-91-50/index.htm. This plan was written to meet the needs of DOE and its contractors and its content, wording, and format are appropriate to those needs. Questions or concerns about this plan should be directed to Mr. D. C. (Dana) Ward, DOE-RL Environmental Assurance, Permits and Policy Division, P. O. Box 550, Richland, Washington 99352 (dana_c_ward@rl.gov). 


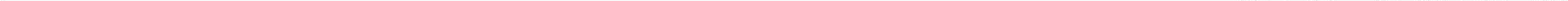




\section{Acronyms/Initialisms}

Each section in this report is considered to be independent from each other with respect to the use of acronyms/initialisms. Any acronym/initialism used in a table or on a figure is provided thereon. For the convenience of the reader, below is a list of all the acronyms/initialisms used in the entire report.

\begin{tabular}{|c|c|}
\hline ALARA & as low as reasonably achievable \\
\hline AP & atmospheric pressure \\
\hline ASME & American Society of Mechanical Engineers \\
\hline BHI & Bechtel Hanford, Inc. \\
\hline $\mathrm{CAD}$ & computer-aided design \\
\hline CERCLA & $\begin{array}{l}\text { Comprehensive Environmental Response, Compensation, and Liability Act of } \\
1980\end{array}$ \\
\hline CFR & Code of Federal Regulations \\
\hline CPP & CERCLA past-practice \\
\hline CVAA & cold vapor atomic absorption \\
\hline CVAF & cold vapor atomic fluorescence \\
\hline DOE & U.S. Department of Energy \\
\hline DP & dew-point temperature \\
\hline Ecology & State of Washington Department of Ecology \\
\hline $\mathrm{EDE}$ & effective dose equivalent \\
\hline EPA & U.S. Environmental Protection Agency \\
\hline ERA & expedited response action \\
\hline ETF & effluent treatment facility \\
\hline FDH & Fluor Daniel Hanford, Inc. \\
\hline FEMP & facility effluent-monitoring plan \\
\hline FFTF & Fast Flux Test Facility \\
\hline $\mathrm{Ge}(\mathrm{Li})$ & lithium-ion drifted germanium (detector) \\
\hline GFAA & graphic furnace atomic absorption \\
\hline GIS & geographic information system \\
\hline HEHF & Hanford Environmental Health Foundation \\
\hline HEIS & Hanford Environmental Information System \\
\hline HMS & Hanford Meteorology Station \\
\hline HPGE & hyperpure germanium (detector) \\
\hline $\mathrm{HQ}$ & Headquarters (DOE) \\
\hline HTO & tritiated water vapor \\
\hline IBM & International Business Machines \\
\hline ICP/MS & inductively coupled plasma/mass spectrometry \\
\hline LEPD & low-energy photon detector \\
\hline LERF & liquid effluent retention facility \\
\hline LLBG & low-level burial ground \\
\hline LLWMA & low-level waste-management area \\
\hline LWDF & liquid waste-disposal facility \\
\hline NPDES & National Pollutant Discharge Elimination System \\
\hline NRDWL & Nonradioactive Dangerous Waste Landfill \\
\hline OU & operable unit \\
\hline $\mathbf{P}$ & precipitation \\
\hline PNNL & Pacific Northwest National Laboratory \\
\hline
\end{tabular}




$\begin{array}{ll}\text { PUREX } & \text { Plutonium-Uranium Extraction Plant } \\ \text { QA } & \text { quality assurance } \\ \text { QC } & \text { quality control } \\ \text { RCRA } & \text { Resource Conservation and Recovery Act of 1976 } \\ \text { REDOX } & \text { Reduction-Oxidation Plant } \\ \text { RL } & \text { Richland Operations Office (DOE) } \\ \text { ROD } & \text { record of decision } \\ \text { RPP } & \text { RCRA past-practice } \\ \text { SARA } & \text { Superfund Amendments and Reauthorization Act of 1986 } \\ \text { SOW } & \text { statement(s) of work } \\ \text { SST } & \text { single-shell tank(s) } \\ \text { SWL } & \text { Solid Waste Landfill } \\ \text { T } & \text { temperature } \\ \text { TD } & \text { temperature difference } \\ \text { TEDF } & \text { treated effluent disposal facility } \\ \text { TLD } & \text { thermoluminescent dosimeter } \\ \text { Tri-Party } & \text { Shortened form for the Hanford Federal Facility Agreement and Consent Order } \\ \text { Agreement } & \text { Between the U.S. Environmental Protection Agency, the U.S. Department of } \\ & \text { Energy; and the State of Washington Department of Ecology, Moy 15, 1989 } \\ \text { TSD } & \text { treatment, storage, or disposal (unit) } \\ \text { UO } & \text { Uranium-Trioxide Plant } \\ \text { WAC } & \text { Washington Administrative Code } \\ \text { WD } & \text { wind direction } \\ \text { WMA } & \text { waste-management area } \\ \text { WRAP } & \text { Waste Receiving and Processing Facility } \\ \text { WS } & \text { wind speed } \\ \text { WSCF } & \text { Waste Sampling and Characterization Facility }\end{array}$




\section{Contents}

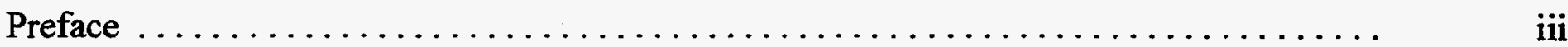

Acronyms/Initialisms $\ldots \ldots \ldots \ldots \ldots \ldots \ldots \ldots \ldots \ldots \ldots \ldots \ldots \ldots \ldots \ldots, \quad \mathbf{v}$

Section I. Introduction

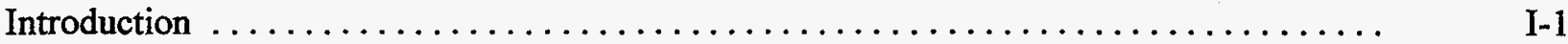

Effluent Monitoring $\ldots \ldots \ldots \ldots \ldots \ldots \ldots \ldots \ldots \ldots \ldots \ldots \ldots \ldots \ldots \ldots \ldots \ldots \ldots \ldots$

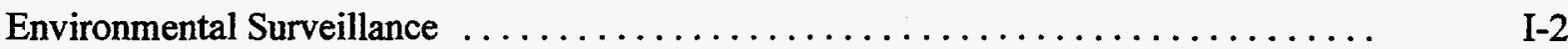

Reporting Requirements $\ldots \ldots \ldots \ldots \ldots \ldots \ldots \ldots \ldots \ldots \ldots \ldots \ldots \ldots \ldots \ldots \ldots \ldots \ldots \ldots$

Independent Data Verification and Oversight Activities $\ldots \ldots \ldots \ldots \ldots \ldots \ldots \ldots$

Overview of the Hanford Site $\ldots \ldots \ldots \ldots \ldots \ldots \ldots \ldots \ldots \ldots \ldots \ldots \ldots \ldots \ldots \ldots \ldots \ldots \ldots$

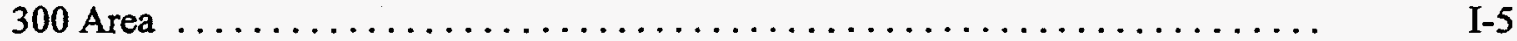

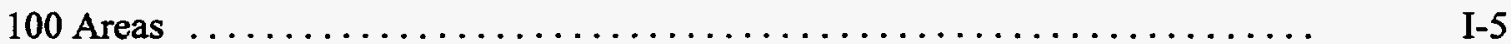

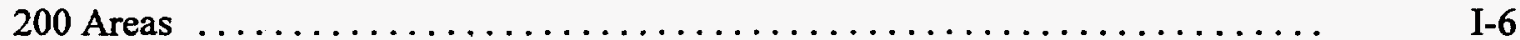

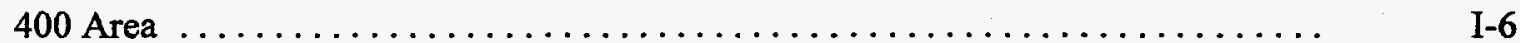

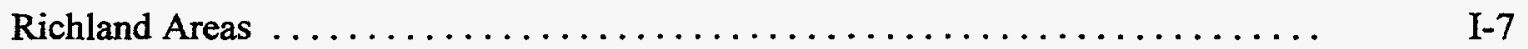

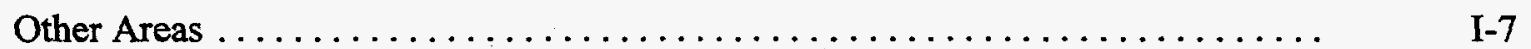

Operations/Conditions Change Notification $\ldots \ldots \ldots \ldots \ldots \ldots \ldots \ldots \ldots \ldots \ldots \ldots \ldots$

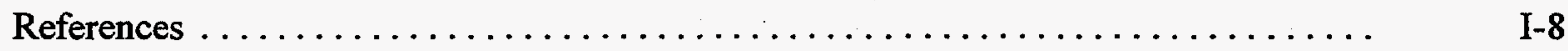

Section II.A. Facility Effluent-Monitoring Plans

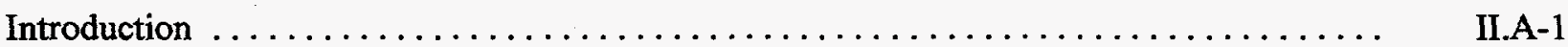

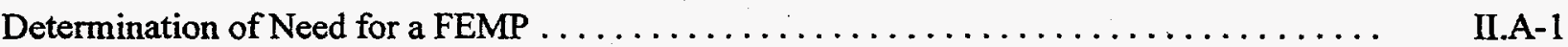

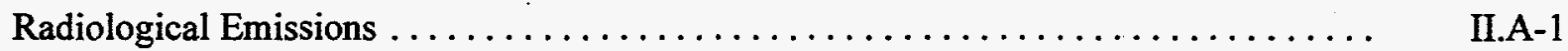

Nonradiological Emissions $\ldots \ldots \ldots \ldots \ldots \ldots \ldots \ldots \ldots \ldots \ldots \ldots \ldots \ldots \ldots \ldots \ldots \ldots \ldots \ldots \ldots \ldots$

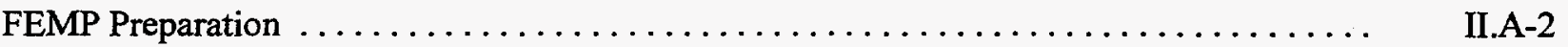

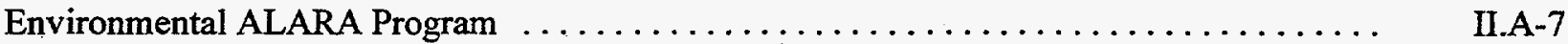

Potential Unmitigated Doses from Hanford Facilities $\ldots \ldots \ldots \ldots \ldots \ldots \ldots \ldots \ldots \ldots$ 


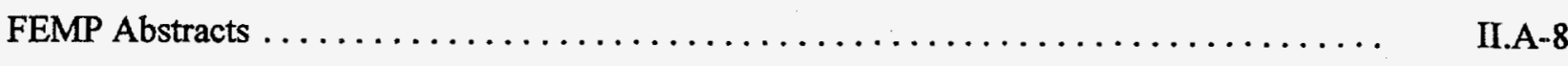

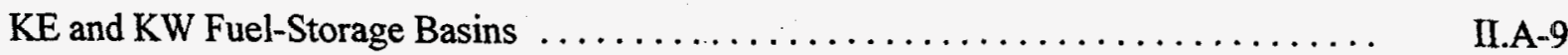

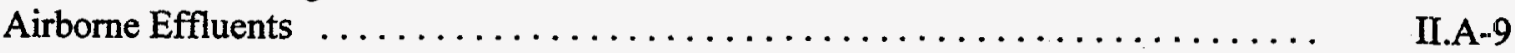

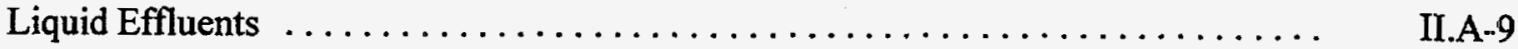

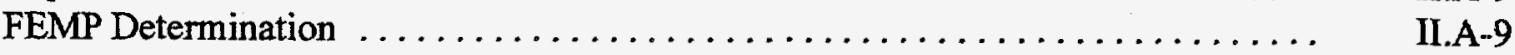

B Plant/Waste Encapsulation and Storage Facility $\ldots \ldots \ldots \ldots \ldots \ldots \ldots \ldots \ldots \ldots \ldots$ II.A-10

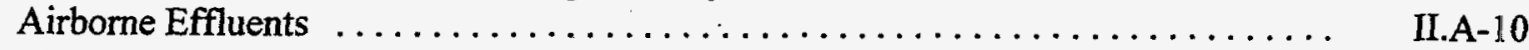

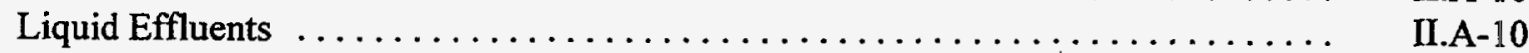

FEMP Determination $\ldots \ldots \ldots \ldots \ldots \ldots \ldots \ldots \ldots \ldots \ldots \ldots \ldots \ldots \ldots \ldots$ II.A-10

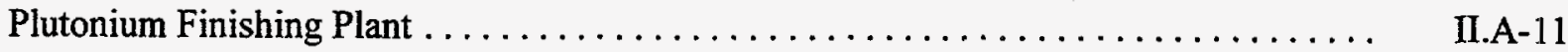

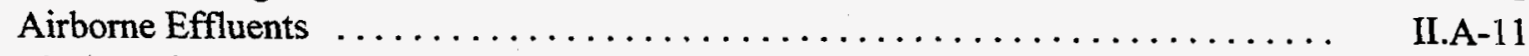

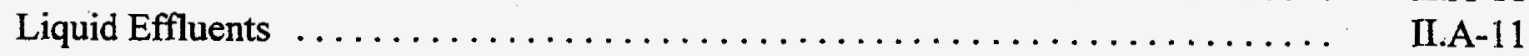

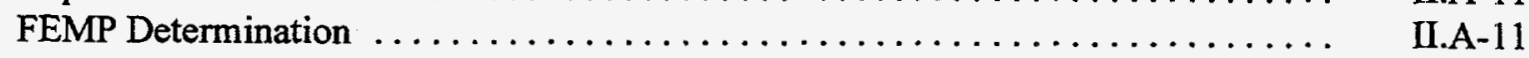

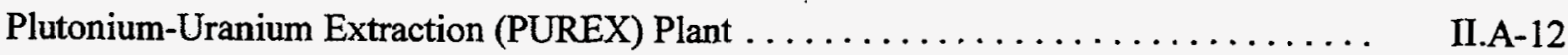

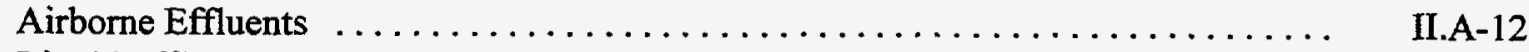

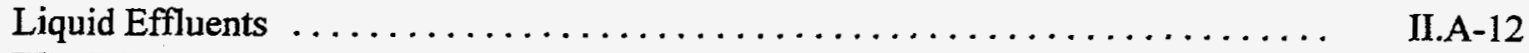

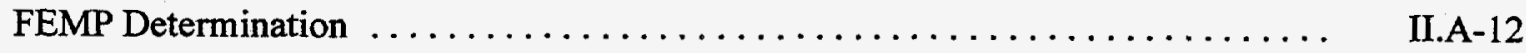

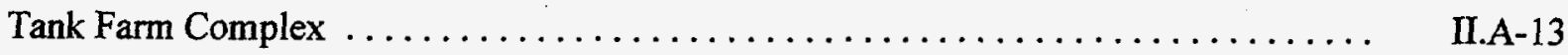

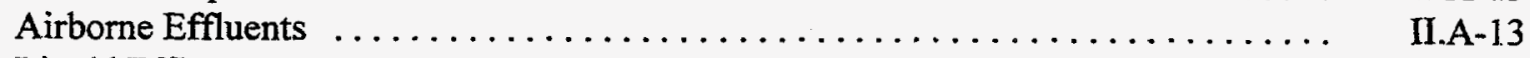

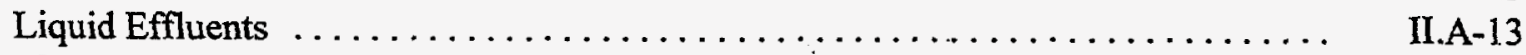

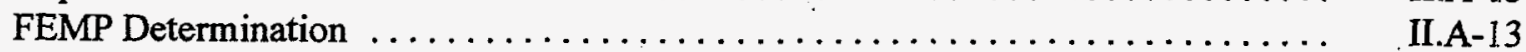

Waste Receiving and Processing Facility (Module 1) $\ldots \ldots \ldots \ldots \ldots \ldots \ldots \ldots \ldots \ldots$ U.A-14

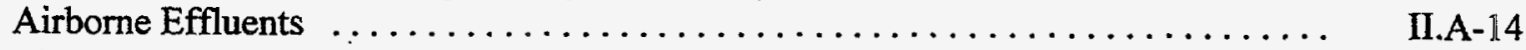

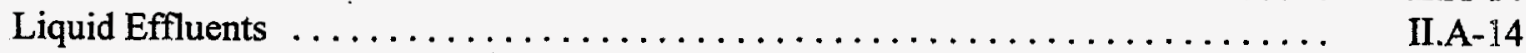

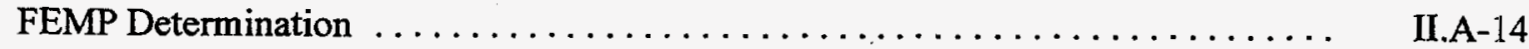

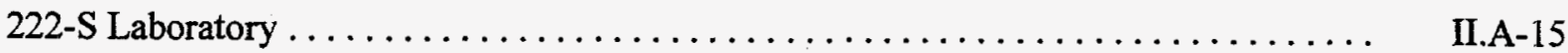

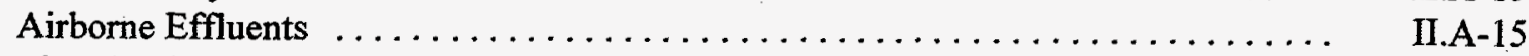

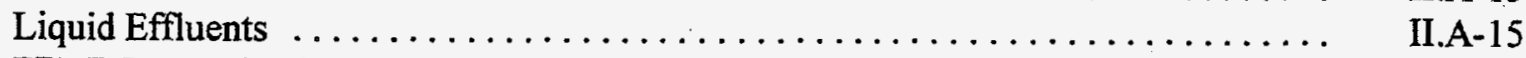

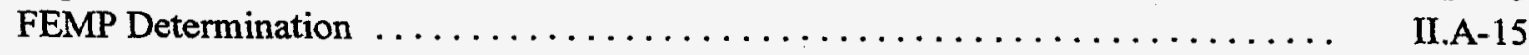

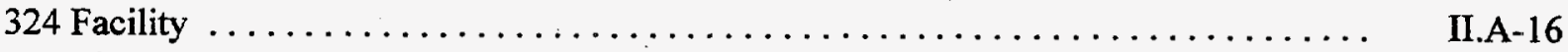

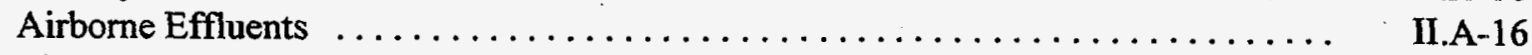

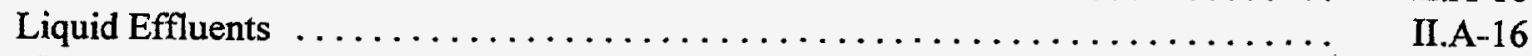

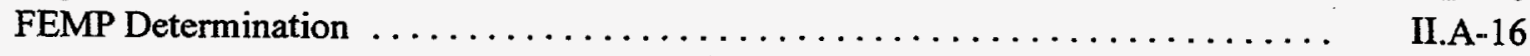

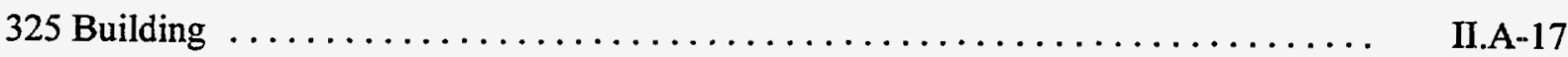

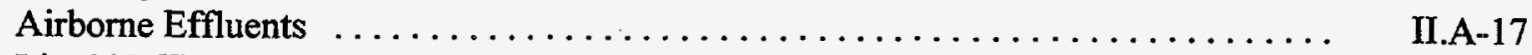

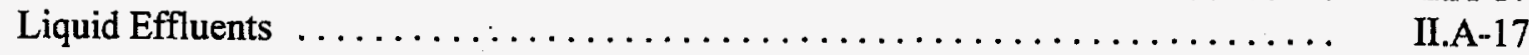

FEMP Determination $\ldots \ldots \ldots \ldots \ldots \ldots \ldots \ldots \ldots \ldots \ldots \ldots \ldots \ldots \ldots \ldots \ldots \ldots \ldots$ II.A -17

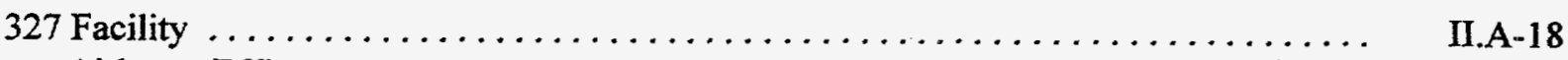

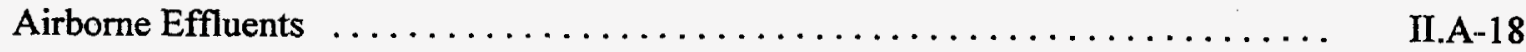




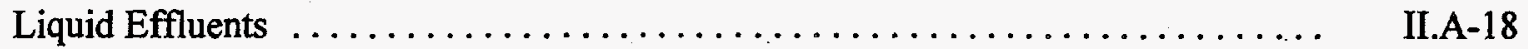

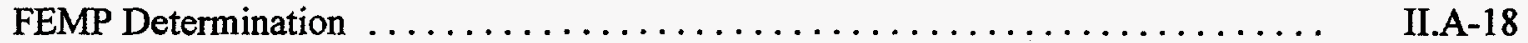

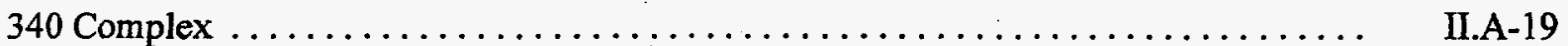

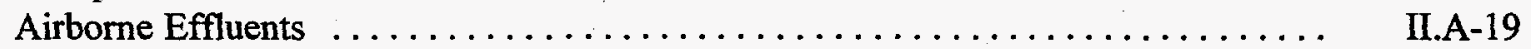

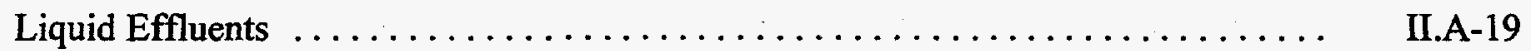

FEMP Determination $\ldots \ldots \ldots \ldots \ldots \ldots \ldots \ldots \ldots \ldots \ldots \ldots \ldots \ldots \ldots \ldots \ldots$ II.A-19

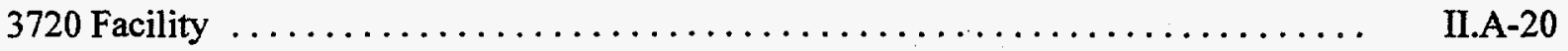

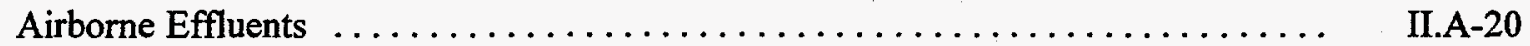

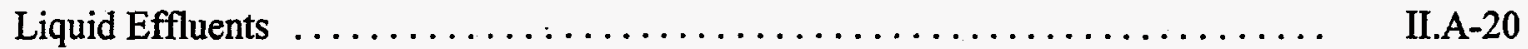

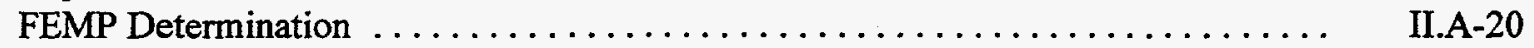

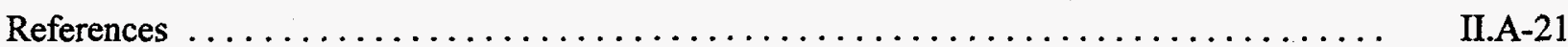

\section{Section II.B. Near-Facility Environmental Monitoring}

Introduction $\ldots \ldots \ldots \ldots \ldots \ldots \ldots \ldots \ldots \ldots \ldots \ldots \ldots \ldots \ldots \ldots \ldots \ldots \ldots \ldots \ldots \ldots \ldots \ldots$

Preoperational Environmental Survey $\ldots \ldots \ldots \ldots \ldots \ldots \ldots \ldots \ldots \ldots \ldots \ldots \ldots \ldots \ldots \ldots \ldots \ldots$ II.B-1

User Identification $\ldots \ldots \ldots \ldots \ldots \ldots \ldots \ldots \ldots \ldots \ldots \ldots \ldots \ldots \ldots \ldots \ldots \ldots \ldots \ldots \ldots$

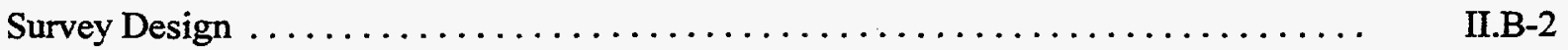

Routine Near-Facility Environmental Monitoring $\ldots \ldots \ldots \ldots \ldots \ldots \ldots \ldots \ldots \ldots \ldots \ldots \ldots$ II.B-2

User Identification $\ldots \ldots \ldots \ldots \ldots \ldots \ldots \ldots \ldots \ldots \ldots \ldots \ldots \ldots \ldots \ldots \ldots \ldots \ldots \ldots \ldots \ldots \ldots$

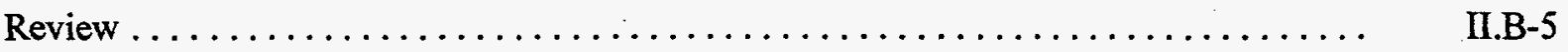

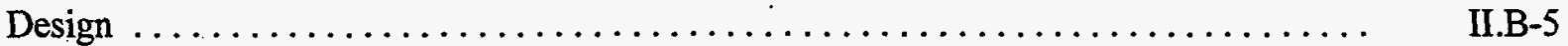

Sampling Locations, Frequency, Media Sampled, and Parameters Monitored . . . . . II.B-5

Monitoring Locations . . . . . . . .

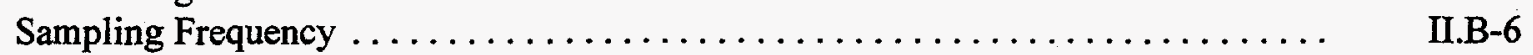

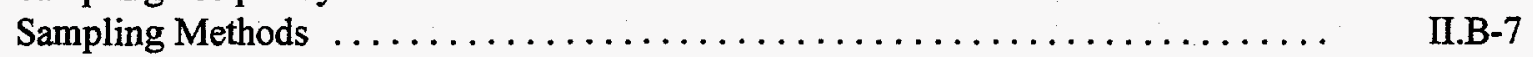

Parameters Monitored $\ldots \ldots \ldots \ldots \ldots \ldots \ldots \ldots \ldots \ldots \ldots \ldots \ldots \ldots \ldots \ldots \ldots \ldots$ II.B-8

References $\ldots \ldots \ldots \ldots \ldots \ldots \ldots \ldots \ldots \ldots \ldots \ldots \ldots \ldots \ldots \ldots \ldots \ldots \ldots \ldots \ldots \ldots$ II.B-9

Section III.A. Surface Environmental Surveillance

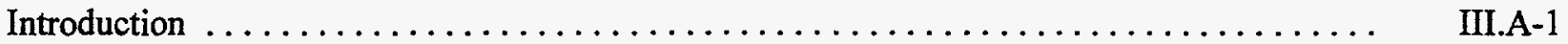

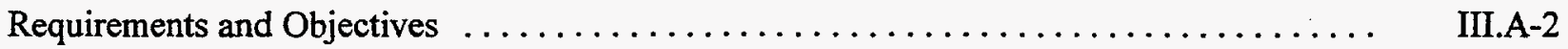

Surface Environmental Surveillance Design $\ldots \ldots \ldots \ldots \ldots \ldots \ldots \ldots \ldots \ldots \ldots \ldots \ldots \ldots \ldots$ III.A-3 


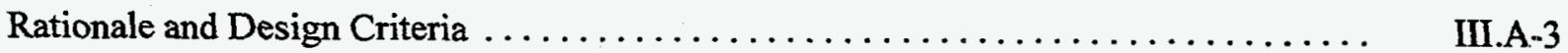

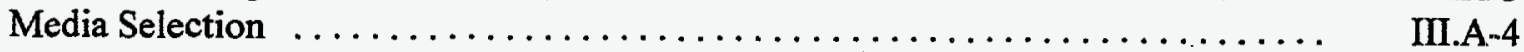

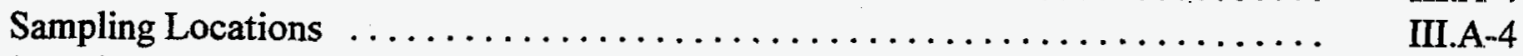

Sampling and Analysis Frequencies $\ldots \ldots \ldots \ldots \ldots \ldots \ldots \ldots \ldots \ldots \ldots \ldots \ldots \ldots \ldots \ldots$ III.A.5

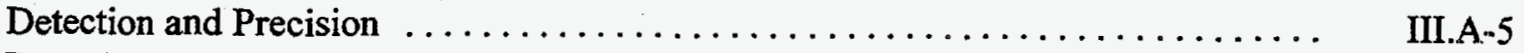

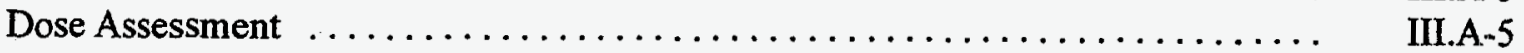

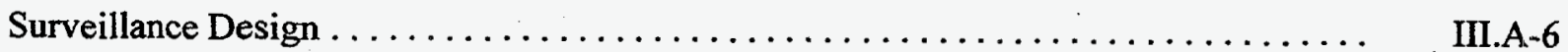

Annual Design-Review Process $\ldots \ldots \ldots \ldots \ldots \ldots \ldots \ldots \ldots \ldots \ldots \ldots \ldots \ldots \ldots \ldots \ldots \ldots \ldots \ldots$

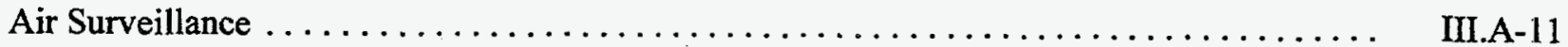

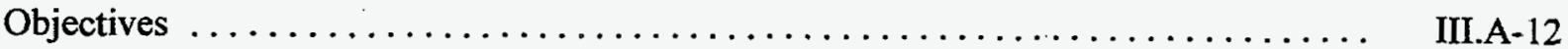

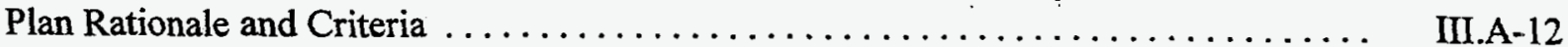

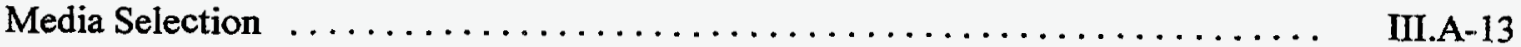

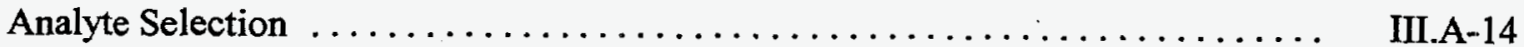

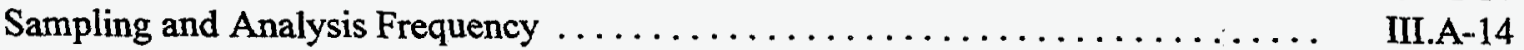

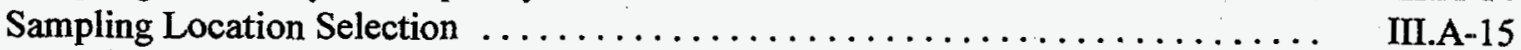

Sampling or Measurement Method Selection $\ldots \ldots \ldots \ldots \ldots \ldots \ldots \ldots$ III.A-16

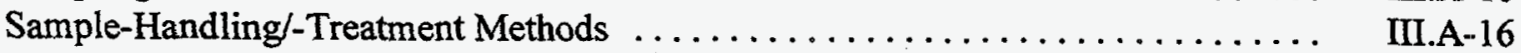

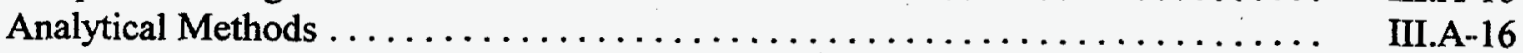

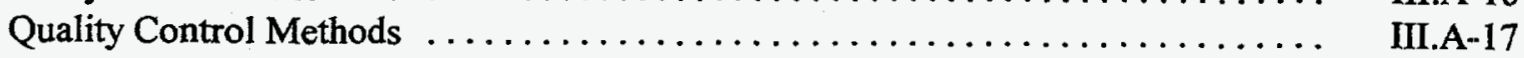

Reporting/Alarm Levels ........................... III

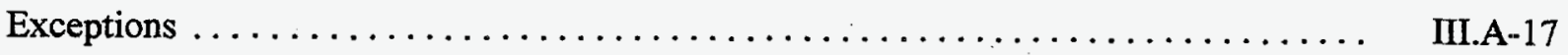

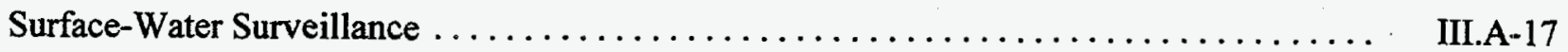

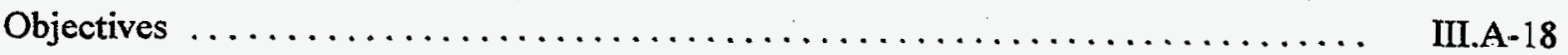

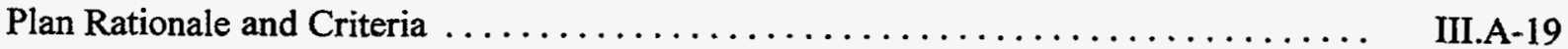

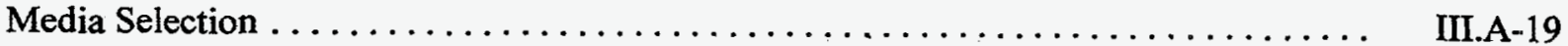

Columbia River .................................... II9

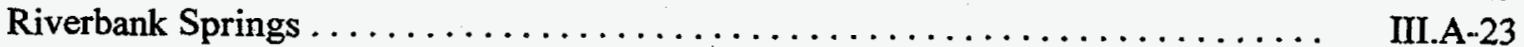

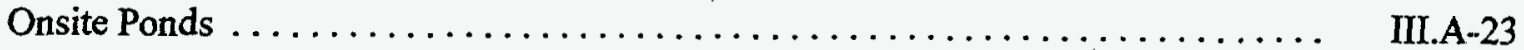

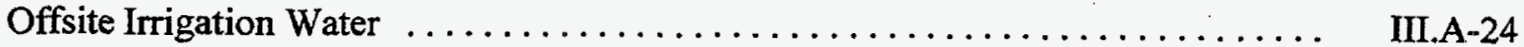

Quality Control Methods . ............................. III.A.

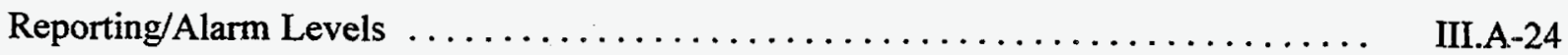

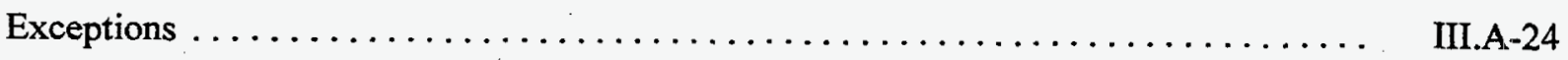

Sediment Surveillance $\ldots \ldots \ldots \ldots \ldots \ldots \ldots \ldots \ldots \ldots \ldots \ldots \ldots \ldots \ldots \ldots \ldots \ldots \ldots \ldots \ldots \ldots \ldots . .24$

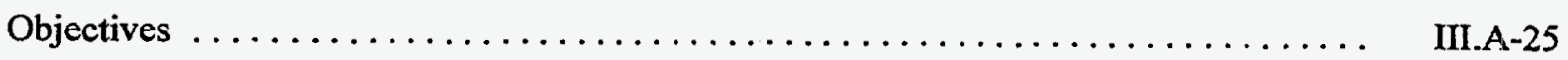




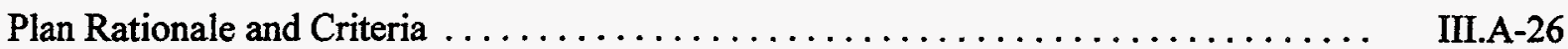

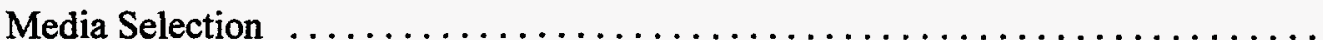

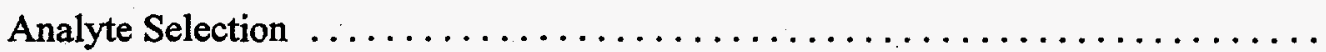

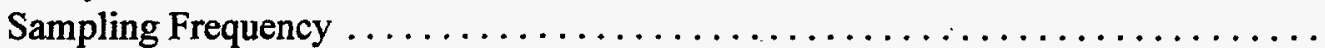

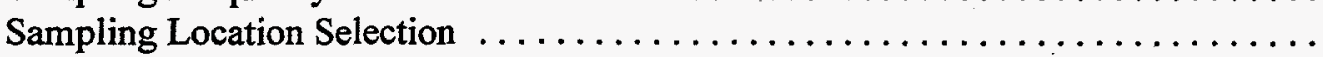

Sample-Collection Methods . . . . . . . . . . . . . . . . . . . . . .

Analytical Methods . . . . . . . . . . . . . . . . . . . . . . . . . . .

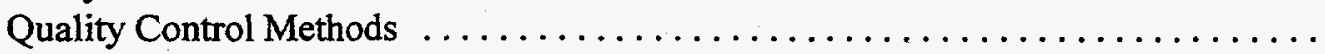

Reporting/Alarm Levels

III.A-26

III.A-26

III.A-26

III.A-27

III.A-28

III.A-28

III.A-28

III.A-28

Exceptions

III.A-28

Biota and Soil Surveillance

III.A-28

Objectives

III.A-30

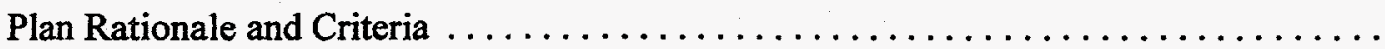

III.A-31

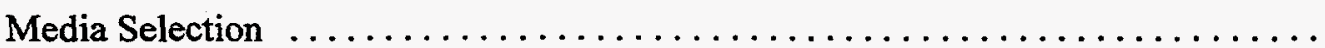

III.A-31

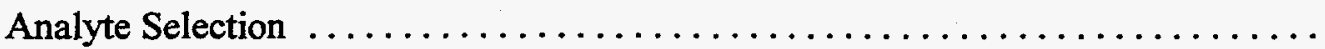

III.A-33

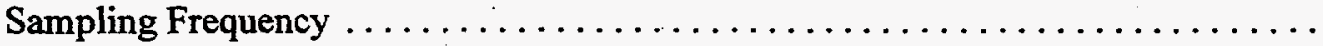

III.A-33

Sampling Location Selection

III.A-34

Sampling or Measurement Methods

III.A-37

Sample-Handling/-Treatment Methods $\ldots \ldots \ldots \ldots \ldots \ldots \ldots \ldots \ldots \ldots \ldots$

Analytical Methods

III.A-37

III.A-37

Quality Control Methods

III.A-38

Reporting/Alarm Levels

III.A-38

Exceptions

III.A-38

External Radiation Surveillance

III.A-38

Objectives

III.A-39

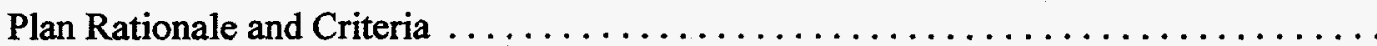

III.A-39

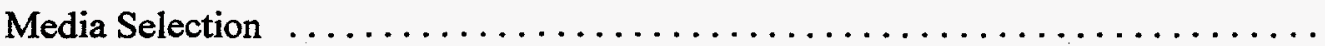

III.A-40

Analyte Selection

III.A-40

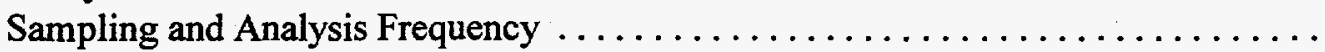

Sampling Location Selection

III.A-40

Sampling or Measurement Methods Selection $\ldots \ldots \ldots \ldots \ldots \ldots \ldots \ldots \ldots$

III.A-41

III.A-42

Sample-Handling/-Treatment Methods

III.A-42

Analytical Methods

III.A-42

Quality Control Methods

III.A-43

Reporting/Alarm Levels

III.A-43

Exceptions

III.A-43

Dose Assessment Methods

III.A-44

Types of Dose Calculations Performed .

III.A-44 


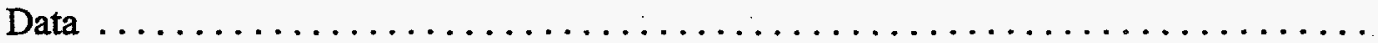

Population Distribution and Atmospheric Dispersion

III.A-46

Terrestrial and Aquatic Pathways

III.A-46

Public Exposure

III.A-46

III.A-47

Dose Calculation Documentation $\ldots \ldots \ldots \ldots \ldots \ldots \ldots \ldots \ldots \ldots \ldots \ldots \ldots \ldots \ldots \ldots \ldots \ldots$ III.A-47

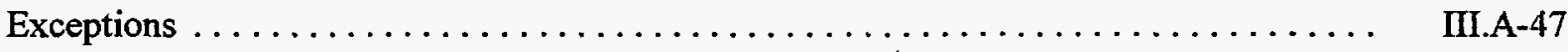

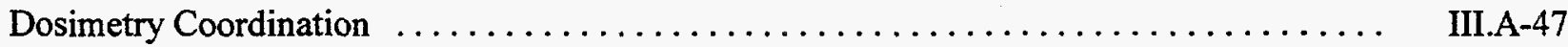

Hanford Environmental Dose Overview Panel $\ldots \ldots \ldots \ldots \ldots \ldots \ldots \ldots \ldots \ldots \ldots$ III.A-47

Support for Software, Databases, and Other Risk-Assessment Methods . . . . . . . III.A-48

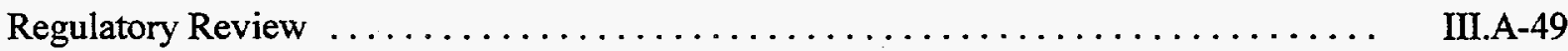

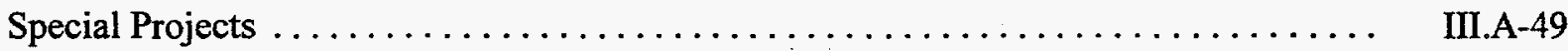

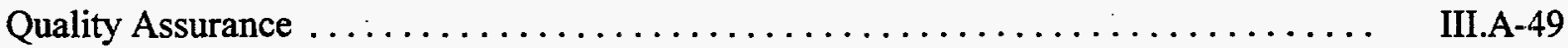

Exceptions $\ldots \ldots \ldots \ldots \ldots \ldots \ldots \ldots \ldots \ldots \ldots \ldots \ldots \ldots \ldots \ldots \ldots \ldots \ldots \ldots \ldots \ldots \ldots \ldots$ III.A -49

Data Management, Analysis, and Statistical Treatment $\ldots \ldots \ldots \ldots \ldots \ldots \ldots \ldots \ldots \ldots \ldots \ldots$

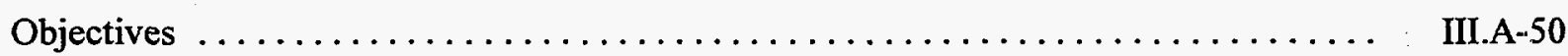

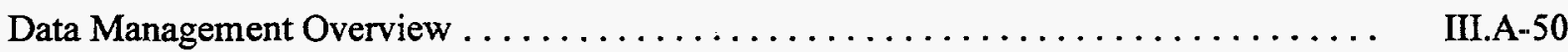

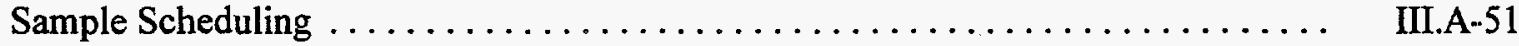

Sample Collection ..................

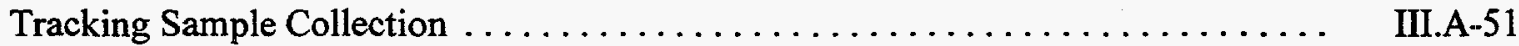

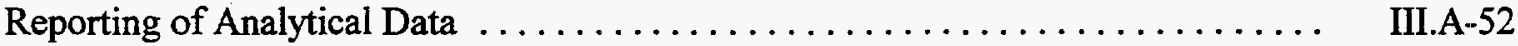

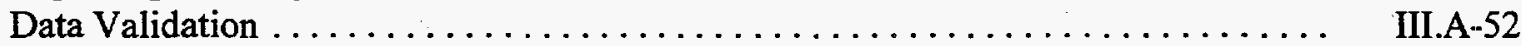

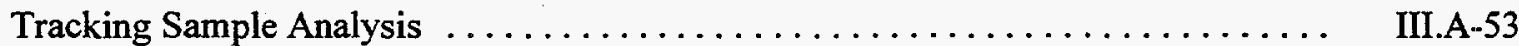

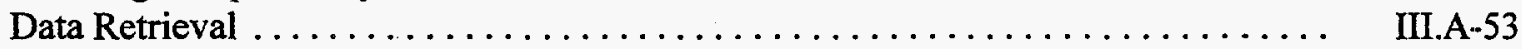

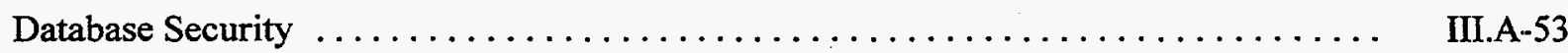

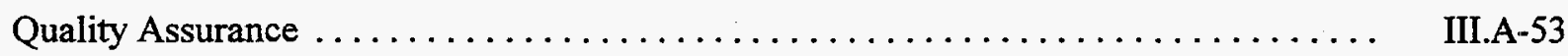

Data Analysis and Statistical Treatment $\ldots \ldots \ldots \ldots \ldots \ldots \ldots \ldots \ldots \ldots \ldots \ldots \ldots \ldots \ldots \ldots \ldots$

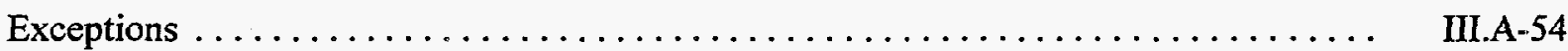

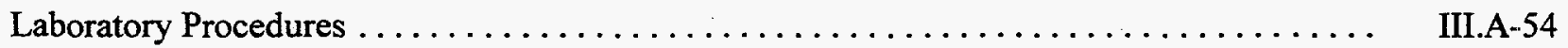

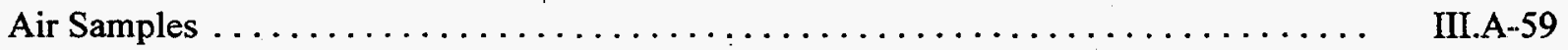

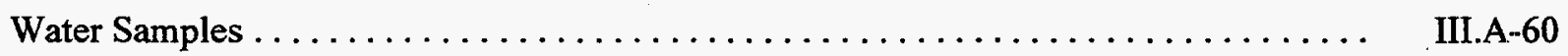


Milk

III.A-62

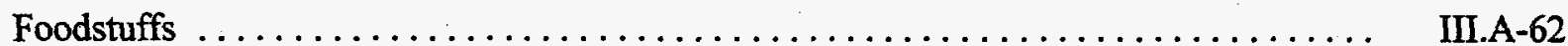

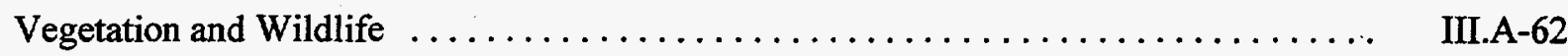

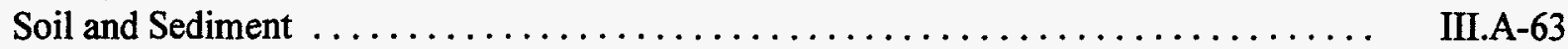

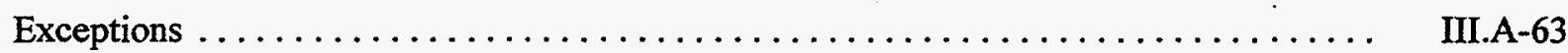

Quality Assurance and Quality Control $\ldots \ldots \ldots \ldots \ldots \ldots \ldots \ldots \ldots \ldots \ldots \ldots \ldots \ldots$ III.A-63

Requirements . .................

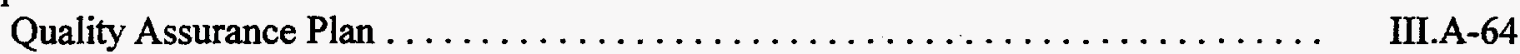

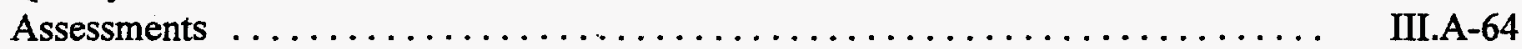

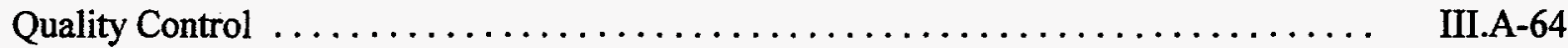

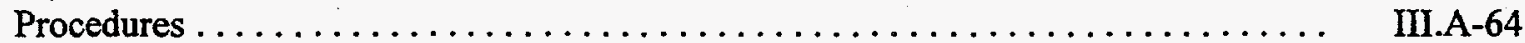

Analytical Quality Control Program ................... III.A 64

Analytical Accuracy and Precision Criteria $\ldots \ldots \ldots \ldots \ldots \ldots \ldots \ldots \ldots \ldots \ldots \ldots$ III.A-66

Field Radiation Survey Instruments $\ldots \ldots \ldots \ldots \ldots \ldots \ldots \ldots \ldots \ldots \ldots \ldots \ldots \ldots$ III.A-67

Exceptions $\ldots \ldots \ldots \ldots \ldots \ldots \ldots \ldots \ldots \ldots \ldots \ldots \ldots \ldots \ldots \ldots \ldots \ldots \ldots \ldots \ldots \ldots \ldots \ldots$ III.A -67

Records Management and Reporting $\ldots \ldots \ldots \ldots \ldots \ldots \ldots \ldots \ldots \ldots \ldots \ldots \ldots \ldots \ldots \ldots \ldots \ldots$

Record Keeping $\ldots \ldots \ldots \ldots \ldots \ldots \ldots \ldots \ldots \ldots \ldots \ldots \ldots \ldots \ldots \ldots \ldots \ldots \ldots \ldots \ldots \ldots$ III.A 67

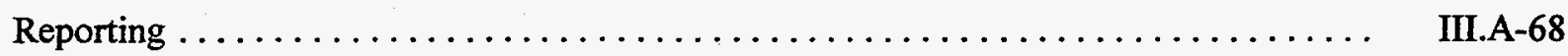

Exceptions $\ldots \ldots \ldots \ldots \ldots \ldots \ldots \ldots \ldots \ldots \ldots \ldots \ldots \ldots \ldots \ldots \ldots \ldots \ldots \ldots \ldots \ldots$ III.A 69

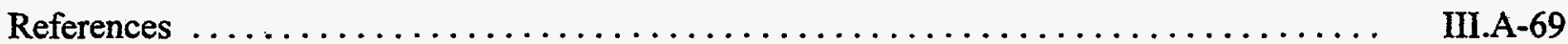

\section{Section III.B. Groundwater Monitoring}

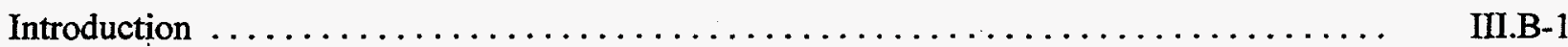

Regulatory Drivers $\ldots \ldots \ldots \ldots \ldots \ldots \ldots \ldots \ldots \ldots \ldots \ldots \ldots \ldots \ldots \ldots \ldots \ldots \ldots \ldots \ldots$ III.B-1

Project Management and Objectives $\ldots \ldots \ldots \ldots \ldots \ldots \ldots \ldots \ldots \ldots \ldots \ldots \ldots \ldots \ldots \ldots \ldots \ldots$ III.B-2

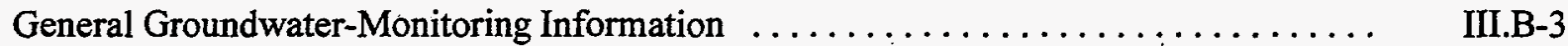

Construction and Maintenance of Wells $\ldots \ldots \ldots \ldots \ldots \ldots \ldots \ldots \ldots \ldots \ldots \ldots$ III.B-3

Hydrologic Characterization and Modeling . . . . . . . . . . . . .

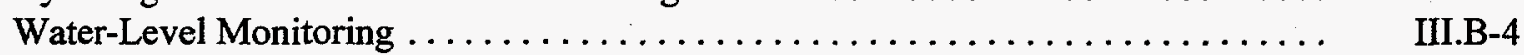

Groundwater Sampling and Analysis $\ldots \ldots \ldots \ldots \ldots \ldots \ldots \ldots \ldots \ldots \ldots \ldots \ldots$ III.B-5 
Data Management and Interpretation $\ldots \ldots \ldots \ldots \ldots \ldots \ldots \ldots \ldots \ldots \ldots \ldots \ldots \ldots \ldots \ldots, \quad$ III.B-8

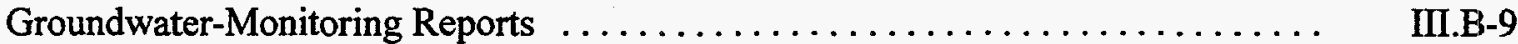

RCRA and Operational Groundwater Monitoring $\ldots \ldots \ldots \ldots \ldots \ldots \ldots \ldots \ldots \ldots \ldots$ III.ES-9

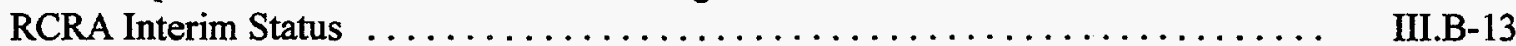

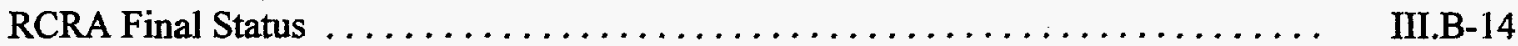

CERCLA Past-Practice/RCRA Corrective Action Groundwater Monitoring . . . . . . III.B-15

Sitewide Environmental Surveillance of Groundwater $\ldots \ldots \ldots \ldots \ldots \ldots \ldots$ III.B-17

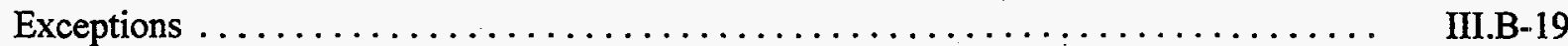

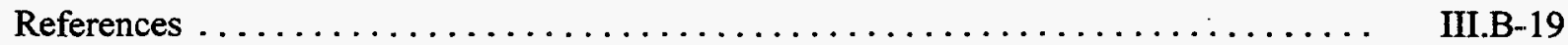

\section{Section III.C. Meteorological Monitoring}

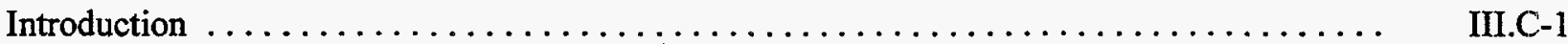

Meteorological and Climatological Services Project $\ldots \ldots \ldots \ldots \ldots \ldots \ldots \ldots \ldots \ldots$ III.C-1

Meteorological Monitoring Network $\ldots \ldots \ldots \ldots \ldots \ldots \ldots \ldots \ldots \ldots \ldots \ldots \ldots \ldots \ldots \ldots \ldots$ III.C-2

Meteorological Instrumentation $\ldots \ldots \ldots \ldots \ldots \ldots \ldots \ldots \ldots \ldots \ldots \ldots \ldots \ldots \ldots \ldots \ldots \ldots$ III.C-2

Instrument Calibration and Maintenance $\ldots \ldots \ldots \ldots \ldots \ldots \ldots \ldots \ldots \ldots \ldots \ldots \ldots \ldots$ III.C-8

Data Acquisition $\ldots \ldots \ldots \ldots \ldots \ldots \ldots \ldots \ldots \ldots \ldots \ldots \ldots \ldots \ldots \ldots \ldots \ldots \ldots \ldots \ldots \ldots$ III.C-8

Atmospheric Transport and Diffusion $\ldots \ldots \ldots \ldots \ldots \ldots \ldots \ldots \ldots \ldots \ldots \ldots \ldots \ldots \ldots \ldots \ldots \ldots$ III.C-8

Quality Assurance $\ldots \ldots \ldots \ldots \ldots \ldots \ldots \ldots \ldots \ldots \ldots \ldots \ldots \ldots \ldots \ldots \ldots \ldots \ldots \ldots \ldots \ldots$

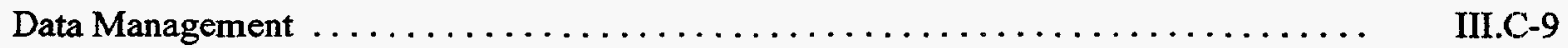

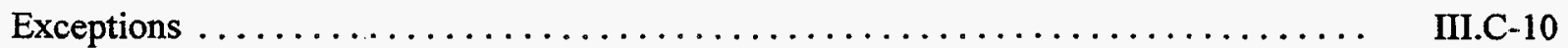

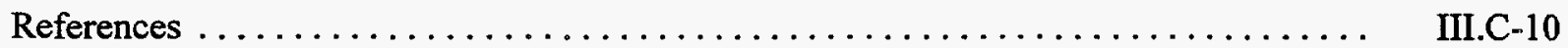




\section{Figures}

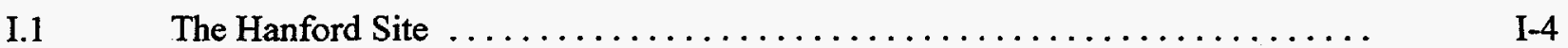

III.A-1 Primary Exposure Pathways to Man $\ldots \ldots \ldots \ldots \ldots \ldots \ldots \ldots \ldots \ldots \ldots \ldots \ldots \ldots$ III.A-7

III.A-2 Radiation and Chemical Exposure Pathways to Biota $\ldots \ldots \ldots \ldots \ldots \ldots \ldots$ III.A-8

III.A-3 Air-Sampling Locations $\ldots \ldots \ldots \ldots \ldots \ldots \ldots \ldots \ldots \ldots \ldots \ldots \ldots \ldots \ldots \ldots \ldots \ldots \ldots$

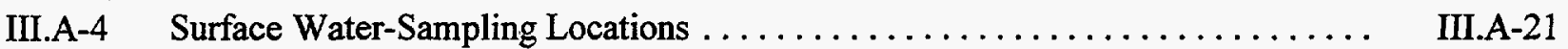

III.A-5 Sediment-Sampling Locations $\ldots \ldots \ldots \ldots \ldots \ldots \ldots \ldots \ldots \ldots \ldots \ldots \ldots \ldots \ldots \ldots \ldots \ldots$

III.A-6 Food- and Farm Product-Sampling Locations $\ldots \ldots \ldots \ldots \ldots \ldots \ldots \ldots \ldots$ III.A-32

III.A-7 Soil- and Vegetation-Sampling Locations $\ldots \ldots \ldots \ldots \ldots \ldots \ldots \ldots \ldots \ldots \ldots \ldots$

III.A-8 Wildlife-Sampling Locations, Excluding Background Area $\ldots \ldots \ldots \ldots \ldots \ldots$ III.A-36

III.B-1 Unconfined Aquifer-Monitoring Wells Sampled in Fiscal Year $1996 \ldots \ldots \ldots \ldots$ III.B-6

III.B-2 Basalt-Confined Aquifer-Monitoring Wells Sampled in Fiscal Year $1996 \ldots \ldots$ III.B-7

III.B-3 Hanford Site RCRA Facilities Requiring Groundwater Monitoring . . . . . . III.B-10

III.B-4 Groundwater Operable Units on the Hanford Site $\ldots \ldots \ldots \ldots \ldots \ldots \ldots \ldots$ III.B-16

III.C-1 Meteorological Monitoring Stations on the Hanford Site and in Surrounding

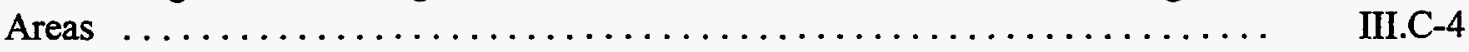




\section{Tables}

II.A-1. Facilities Determination Results $\ldots \ldots \ldots \ldots \ldots \ldots \ldots \ldots \ldots \ldots \ldots \ldots \ldots \ldots \ldots$

II.B-1 Governing Documents $\ldots \ldots \ldots \ldots \ldots \ldots \ldots \ldots \ldots \ldots \ldots \ldots \ldots \ldots \ldots \ldots \ldots \ldots \ldots$

II.B-2 Near-Field Sampling Media, Frequency, Analytes, and Parameters . . . . . . . II.B-6

III.A-1 Radiological Monitoring Sampling Summary $\ldots \ldots \ldots \ldots \ldots \ldots \ldots \ldots \ldots$ III.A-54

III.A-2 Chemical Monitoring Sampling Summary $\ldots \ldots \ldots \ldots \ldots \ldots \ldots \ldots \ldots \ldots$ III.A-58

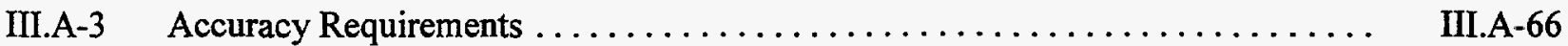

III.A-4 Hanford Site Surface Environmental Surveillance Concentration Reporting Levels . . . . . . . . . . . . . . . .

III.B-1 Hanford Site Interim- and Final-Status Groundwater-Monitoring Projects $\ldots . . \quad$ III.B-11

III.B-2 Groundwater Operable Unit Summary - Environmental Monitoring $\ldots \ldots \ldots \ldots$ III.B-17

III.C-1 Hanford Site Meteorological Monitoring Towers $\ldots \ldots \ldots \ldots \ldots \ldots \ldots \ldots \ldots$ III.C-3 
Hanford Site Environmental Monitoring Plan

Section I. Introduction 


\section{Introduction}

This Environmental Monitoring Plan was prepared pursuant to U.S. Department of Energy (DOE) Order 5400.1 to document the elements of the effluent-monitoring and environmental surveillance programs in use at the Hanford Site. When operations and activities take place on the Hanford Site, it is DOE's policy to ensure that the public and the environment are adequately protected through the prevention, control, and abatement of environmental pollution. To this end, DOE is committed to comply with all pertinent federal, state, and local radiation and pollution-control standards, requirements, and policies. At a minimum, the high-priority program elements identified in the guidance document, Environmental Regulatory Guide for Radiological Effluent Monitoring and Environmental Surveillance (DOE/EH-0173T) are addressed in this plan. The high-priority elements are those that "should*" be performed if the monitoring programs are to be acceptable to DOE.

Initially issued in November 1991, this is the second revision of this plan. Revisions are required by DOE guidance every 3 yr. Differences between this revision and the first (previous) revision are relatively small. However, some text and tables have been deleted and replaced with references to existing documents in an effort to eliminate duplication and decrease the physical bulk of this plan. Section III-B, Groundwater Monitoring, has been expanded to also include the information formerly contained in Section IV.A, Environmental Restoration/Groundwater. As a result, Section IV.A has been deleted from this revision.

The effluent-monitoring and environmental surveillance programs currently in place at the Hanford Site are discussed briefly below. Contractor responsibilities and the State of Washington's role in data verification and oversight activities are discussed. An overview of the Hanford Site and a brief discussion of plan changes and responsibilities are also included.

\section{Effluent Monitoring}

Effluent monitoring at the Hanford Site is divided into two categories: 1) facility effluent monitoring and 2) near-facility environmental monitoring. Facility effluent monitoring is performed at each facility by the operating contractor. Within this plan, a facility is defined as a building, structure, or group of buildings that release radionuclides (DOE/EH-0173T). Evaluations of all Hanford Site facilities having the potential to release gaseous or liquid effluents to the environment were conducted, as required by DOE Order 5400.1 , through a facility effluent-monitoring plan determination process. Plans were prepared for all facilities identified during the determination process as having the potential to discharge contaminants at concentrations exceeding specified exposure levels. Each contains the rationale and design criteria for the effluent-monitoring program at the facility, information on the extent and frequency of monitoring and measurements, procedures for laboratory analyses, quality assurance requirements, and program implementation procedures. There are currently 12 facilities at the Hanford Site requiring such plans; brief abstracts are included in Section II-A. A table identifying the facilities evaluated during the determination process is also provided.

Near-facility environmental monitoring (formerly called operational environmental monitoring) is conducted by Waste Management Federal Services, Inc., Northwest Operations, an enterprise company. Near-facility environmental monitoring is used to evaluate the adequacy of effluent controls or stabilization efforts near specific facilities or waste-disposal sites. The program monitors contamination 
in air, surface water, groundwater, soil, sediment, vegetation, and biota around facilities near and in the $100,200,300,400,600$, and 1100 Areas. Section II.B of this plan discusses these monitoring activities and contains details or specific references to the rationale and design criteria for the extent and frequency of monitoring and measurements, procedures for laboratory analyses, quality assurance requirements, and program implementation procedures.

\section{Environmental Surveillance}

The environmental surveillance program at the Hanford Site addresses 1) surface environment surveillance, 2) groundwater surveillance, and 3) meteorological monitoring. Surface environmental surveillance is a multimedia environmental monitoring effort conducted by the Pacific Northwest National Laboratory on and off the site to evaluate the environmental impacts of Hanford Site operations and to assess offsite human health exposures. Onsite surveillance is conducted independent of facilityrelated environmental monitoring programs to provide an assessment of the effectiveness of effluent controls. Parameters routinely monitored include air, surface water, sediment, agricultural products, vegetation, soil, and wildlife.

Section III.A contains the detailed rationale and design criteria for the site's environmental surveillance program, extent and frequency of monitoring and measurements, procedures for laboratory analyses, quality assurance requirements, and program implementation procedures.

Section III.B describes the site's groundwater-monitoring activities managed by the Pacific Northwest National Laboratory through its Groundwater Monitoring Project. This project is responsible for assessing the distribution and movement of existing groundwater contamination, both radiological and chemical, and identifying potential and emerging groundwater-contamination problems. Monitoring activities are conducted at active waste-disposal facilities to comply with requirements of the Resource Conservation and Recovery Act of 1976 and State of Washington regulations, as well as requirements for operational monitoring around reactor and chemical-processing facilities, and requirements for environmental surveillance. Groundwater monitoring is also carried out during cleanup investigations under the Comprehensive Environmental Response, Compensation, and Liability Act of 1980 . The cleanup monitoring is managed by Bechtel Hanford, Inc., the site's Environmental Restoration Contractor. Groundwater samples are currently collected from approximately 800 wells, both on and off the site. Groundwater information discussed in this plan includes program design, well locations, sampling frequencies, sampling procedures, analyses performed, data reviews, and rationale for the level of effort devoted to each element.

Section III.C describes the rationale and design of the Meteorological and Climatological Services Project, including the number and location of stations, instrumentation, forecasting capability, data management, diffusion modeling, and emergency response capability. This project is managed and conducted by the Pacific Northwest National Laboratory.

\section{Reporting Requirements}

An annual report, describing the environmental status of the Hanford Site and the surrounding area, is prepared and distributed in accordance with DOE Orders 231.1 and 5400.1 and applicable DOEHeadquarters' guidance. The Hanford Site environmental report (e.g., PNNL-1 1472) includes data 
collected during the calendar year to characterize environmental management performance and demonstrate compliance status. The report also highlights significant environmental programs and efforts. The report is prepared for DOE by Pacific Northwest National Laboratory, Bechtel Hanford, Inc., the Project Hanford Management Contract Team, and other site contractors as appropriate. Document production and coordination are managed by the Pacific Northwest National Laboratory.

An annual groundwater-monitoring report is prepared to meet the reporting requirements of the Resource Conservation and Recovery Act of 1976 and various Hanford Site programs. That report (e.g., PNNL-11470) summarizes the site groundwater-monitoring activities and provides a comprehensive interpretation of groundwater conditions on the site and in adjacent areas. The report is prepared for DOE by Pacific Northwest National Laboratory, Bechtel Hanford, Inc., and the Project Hanford Management Contract Team. Document production and coordination are managed by the Pacific Northwest National Laboratory.

A radiological emissions report is prepared for DOE each calendar year in accordance with the Code of Federal Regulations, Title 40, Part 61, Subpart $\mathrm{H}$, and with the requirements of Washington Administrative Code Chapter 246-247. That report (e.g., DOE/RL-97-43) documents annual radionuclide air emissions from the Hanford Site and the resulting effective dose equivalent to a hypothetical maximally exposed member of the public. An environmental releases report is also produced pursuant to the annual environmental release reporting requirements in DOE Orders 5400.1 and 5484.1. That report (e.g., HNF-EP-0527-6) is a supplement to the Hanford Site environmental report and summarizes the environmental releases from Hanford Site facilities. The emissions report is prepared by Waste Management Federal Services of Hanford, Inc. and Pacific Northwest National Laboratory. Document production and coordination are managed by Waste Management Federal Services of Hanford, Inc. The environmental releases report is prepared by Waste Management Federal Services of Hanford, Inc.

In addition, annual reports detailing the results of near-facility environmental monitoring efforts (e.g., HNF-EP-0573-5) and climatological studies (e.g., PNNL-11471) are prepared for DOE by Waste Management Federal Services of Hanford, Inc. and Pacific Northwest National Laboratory, respectively.

\section{Independent Data Verification and Oversight Activities}

The State of Washington Department of Health was awarded a grant from DOE in March 1990 to conduct independent surveillance, oversight, and data verification at the Hanford Site. The grant provides funds for sample collection, analyses, data compilation and interpretation, and report preparation. They publish the results of their independent activities in a report produced through their Environmental Radiation Program (e.g., State of Washington Department of Health 1993).

\section{Overview of the Hanford Site}

The Hanford Site lies within the semiarid Pasco Basin of the Columbia Plateau in southeastern Washington State. The Hanford Site occupies an area of $\sim 1,450 \mathrm{~km}^{2}$ located north of the City of Richland and the confluence of the Yakima River with the Columbia River (Figure I.1). This large area has restricted public access and provides a buffer for the smaller areas onsite that historically were used for producing nuclear materials, waste storage, and waste disposal. Only $\sim 6 \%$ of the land area has been disturbed and is actively used. The Columbia River flows eastward through the northern part of the Hanford Site and then turns south, forming part of the eastern boundary. The Yakima River flows along 


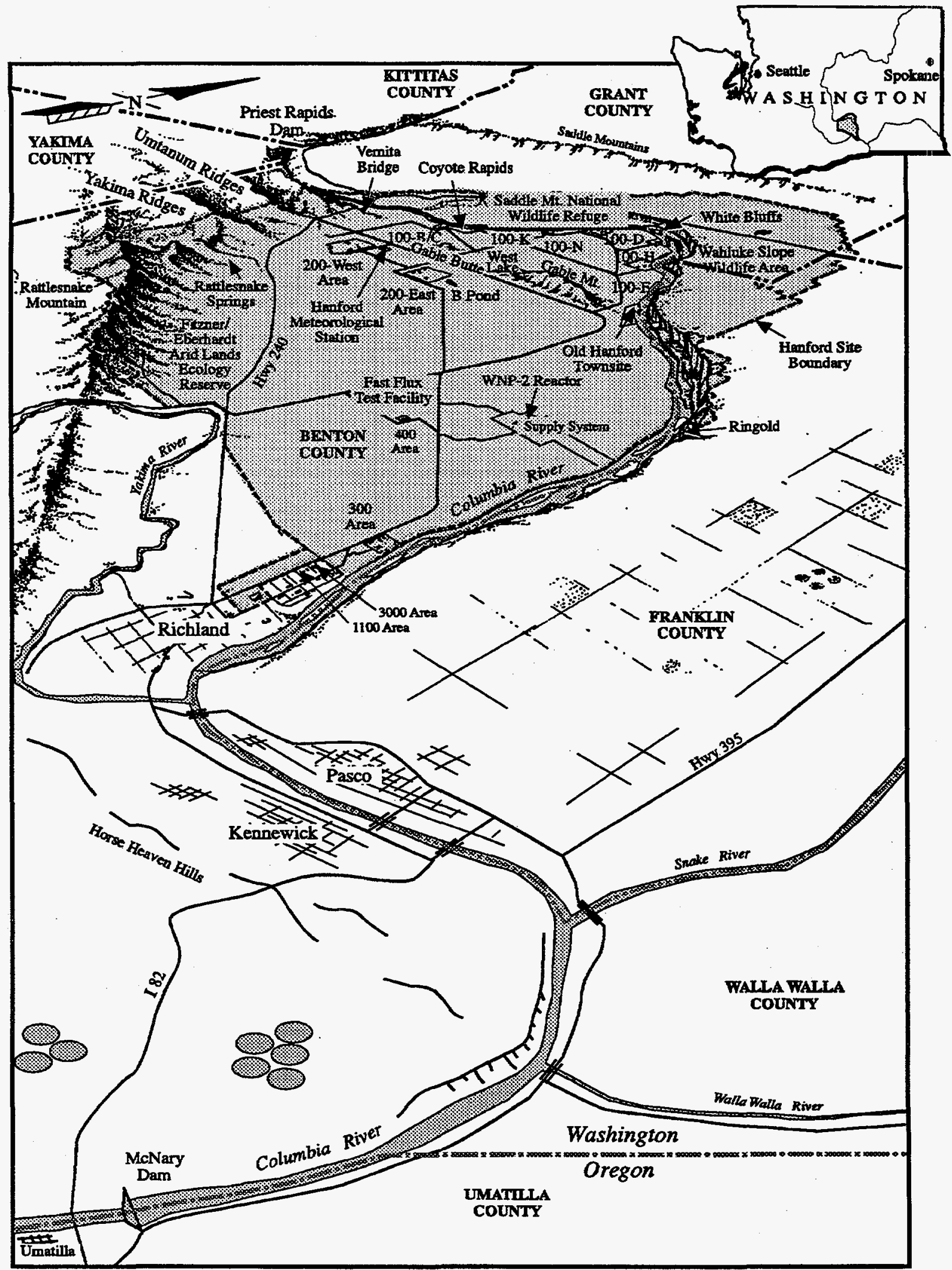

Figure I.1. The Hanford Site

scsercoers 
part of the southern boundary and joins the Columbia River downstream from the City of Richland. Land in the surrounding environs is used for urban and industrial development, irrigated and dry-land farming, and livestock grazing.

The Hanford Site was established in 1943 to produce raw material (plutonium) for nuclear weapons and was the first nuclear production facility in the world. The Hanford Site was selected by the U.S. Army Corps of Engineers because it was remote from major populated areas and had ample electrical power from Grand Coulee Dam, a functional railroad, clean water from the Columbia River, and plenty of onsite sand and gravel for construction. The Hanford Site was divided into a number of operational areas.

Operations at the Hanford Site resulted in the production of liquid, solid, and gaseous wastes. Most wastes resulting from Hanford Site operations have had at least the potential to contain radioactive materials. From an operational standpoint, radioactive liquid wastes were originally categorized as highlevel, intermediate-level, or low-level, depending on the level of radioactivity present. High-level liquid wastes were first stored in large, underground, single-shell tanks. The contents of some of these tanks have since leaked into the soil. In later years, high-level liquid wastes were stored in double-shell tanks, which have not leaked waste into the soil. Intermediate-level liquid waste streams were usually routed to various types of underground structures called cribs. Occasionally, trenches were filled with the liquid waste and then covered with soil after the waste had soaked into the ground. Low-level liquid waste streams were usually routed to surface impoundments (i.e., ditches and ponds). In most cases, intermediateand low-level liquid wastes were allowed to penetrate the soil to the groundwater. Some of the contaminants that reached the groundwater subsequently flowed with the groundwater into the Columbia River.

\section{Area}

From the early 1940 s to the present, most research-and-development activities were carried out in the 300 Area located just north of the City of Richland. The 300 Area was also the location of nuclear fuel fabrication. Nuclear fuel in the form of pipe-like cylinders (i.e., fuel slugs) was fabricated from purified uranium shipped in from offsite production facilities. Metallic uranium was extruded into the proper shape and encapsulated. Copper metal was an important material used in the extrusion process and substantial amounts of copper, uranium, and other heavy metals ended up in 300 Area liquid wastes. Such low-level liquid wastes were routed to ponds located along the shoreline of the Columbia River. In more recent times, the low-level liquid wastes were shipped to a solar evaporation facility in the 100-H Area.

\section{Areas}

The fabricated fuel slugs were shipped by rail from the 300 Area to the 100 Areas. The 100 Areas are located on the shore of the Columbia River, where up to nine nuclear reactors were in operation. The main part of the nuclear reactors consisted of a large stack (i.e., pile) of graphite blocks that had tubes and pipes running through it. The tubes housed the fuel slugs while the pipes carried cooling water that was eventually returned to the Columbia River. The large collection of slightly radioactive uranium in the reactor piles resulted in an extensive radiation field and a radioactive chain reaction that caused some uranium atoms to be converted into plutonium atoms.

The first eight reactors, constructed between 1944 and 1955, used water from the Columbia River for direct cooling. Large quantities of water were pumped through the piles and discharged back into the river. The discharged cooling water contained radioactive materials that escaped from the fuel slugs, tube walls, etc., during the irradiation process. The radiation field in the pile also caused some of the 
impurities in the river water to become radioactive from neutron activation. The ninth reactor, $\mathrm{N}$ Reactor, was completed in 1963 and was of a slightly different design. Purified water was recirculated through the reactor pile in a closed-loop cooling system. Beginning in 1966, heat from the closed-loop system was used to produce steam, which was sold to the Washington Public Power Supply System to generate electricity at the adjacent Hanford Generating Plant. Although N Reactor did not produce heated cooling water that was returned directly to the Columbia River, the reactor did use a large crib near the shoreline for disposing of radioactive water. Drainage from the crib interfaced with the groundwater, and along the shoreline, the drainage created artificial springs containing radioactive materials.

When fresh fuel was pushed into the front of the reactor's graphite pile, irradiated fuel slugs were forced out the rear into a deep pool of water called a fuel-storage basin. After brief storage in the basin and further storage in special freight cars on a railroad siding, the irradiated fuel was transported by rail to the 200 Areas, where the plutonium was recovered. Most of the irradiated fuel produced at N Reactor from the mid-1970s to late 1983 was transported by railcar to the $100-\mathrm{K}$ East and 100-K West fuelstorage basins for temporary storage, where some of it remains today.

\section{Areas}

The 200-East and 200-West Areas are located on a plateau $\sim 11$ and $8 \mathrm{~km}$, respectively, south of the Columbia River. These areas housed facilities called separations plants that received and dissolved irradiated fuel and then separated out the plutonium. The Reduction Oxidation (REDOX) Plant and the Plutonium-Uranium Extraction (PUREX) Plant were the two main separations facilities. These plants produced large quantities of waste nitric acid solutions that contained radioactive materials. High-level wastes were neutralized and stored in large underground tanks. Intermediate-level wastes containing fission products, activation products, and nitrate ion were discharged to cribs. Low-level wastes and cooling water from the plants were distributed by open ditch to surface ponds for evaporation and percolation into the ground.

Because the high-level waste stored in tanks was not acidic, various chemicals and radioactive materials precipitated and settled to the bottom of the tanks. This phenomenon was later used to advantage; the liquid waste was heated in special facilities (e.g., evaporators) to remove excess water and concen-trate the waste into salt cake and sludge, which remained in the tanks. The condensed water contained radioactive tritium and was discharged to cribs.

The REDOX and PUREX Plants produced uranium nitrate for recycle and plutonium nitrate for weapon component production. Uranium oxide was prepared for reuse and packaged for offsite shipment at the Uranium-TriOxide $\left(\mathrm{UO}_{3}\right)$ Plant. The $\mathrm{UO}_{3}$ Plant discharged wastes containing nitrate ion and uranium to cribs and discharged cooling water to a pond. Plutonium nitrate was received for further processing at one of several buildings collectively known as Z Plant (now called the Plutonium Finishing Plant). Processes at this plant used nitric acid, hydrofluoric acid, carbon tetrachloride, and various oils and degreasers. Varying amounts of all these materials ended up in intermediate-level waste streams that were discharged to cribs. Cooling water was sent to a pond by an open ditch.

\section{Area}

In addition to research-and-development activities in the 300 Area, the Hanford Site supported several test facilities. The largest of these was the Fast Flux Test Facility, a special nuclear reactor designed to test various types of nuclear fuel. The facility operated for $\sim 13 \mathrm{yr}$ and has been shut down 
since 1993. The reactor was of a unique design that used liquid metal sodium as the primary coolant. The heated liquid sodium was cooled with atmospheric air in heat exchangers. Generated wastes were transported to the 200 Areas.

\section{Richland Areas}

Areas near the north end of the City of Richland provide Hanford Site support services. The 1100 Area, $\sim 2 \mathrm{~km}$ west of the Columbia River, is the location of general stores and the transportation maintenance facility for the Hanford Site. Operations at the transportation maintenance facility resulted in ground contamination from several chemicals, oils, and greases. No radioactive waste was discharged to the ground in the 1100 Area. The U.S. Army Corps of Engineers completed remedial actions to remove hazardous waste from the 1100 Area in September 1995.

\section{Other Areas}

Several areas, totaling $665 \mathrm{~km}^{2}$, have been set aside for special uses. The Fitzner/Eberhardt Arid Lands Ecology Reserve, used for ecological research, was established in 1967 on land between the southern boundary of the Hanford Site and Highway 240. In 1975, that portion of the Hanford Site located north of the Columbia River was permitted for use by two government agencies. The U.S. Fish and Wildlife Service manages the Saddle Mountain National Wildlife Refuge, and the State of Washington Department of Wildlife manages a game reserve known as the Wahluke Slope Wildlife Recreation Area. Public access to the wildlife refuge is controlled; whereas the recreation area is open to the public during daylight hours for hunting, fishing, and recreation.

Non-DOE nuclear operations and activities include commercial power production by the Washington Public Power Supply System's WNP-2 Reactor (near the 400 Area) and commercial low-level radioactive waste burial at a site leased and licensed by the State of Washington and operated by US Ecology (near the 200 Areas). Near the southern boundary of the Hanford Site, north of Richland, Siemens Power Corporation operates a commercial nuclear fuel fabrication facility, and Allied Technology Group operates a low-level radioactive waste decontamination, super-compaction, and packaging disposal facility.

\section{Operations/Conditions Change Notification}

The potential exists for facility operations and/or environmental conditions to change during the course of the year. These changes may affect the needs for modifications or additions to the existing effluent-monitoring and environmental surveillance programs. To ensure that the need for changes can be evaluated and acted on in a timely manner, bimonthly meetings have been established to exchange information relative to contractor activities and plans for the next 6-mo window. Contractors evaluate these operation/condition changes and document the decisions regarding the need for surveillance changes.

This Environmental Monitoring Plan is controlled and maintained by Pacific Northwest National Laboratory's Public Safety and Resource Protection Program. Modifications to this plan between revisions will be controlled under existing Pacific Northwest National Laboratory project change-control procedures. Substantive deviations from the plan are to be approved by DOE and recorded on the record of changes form. 


\section{References}

40 CFR 61, Code of Federal Regulations, Title 40, Part 61. National Emission Standards for Hazardous Air Pollutants.

Comprehensive Environmental Response, Compensation, and Liability Act of 1980, as amended, Public Law 96-510, 94 Stat. 2767, 42 USC 9601 et seq.

DOE/EH-0173T. 1991. Environmental Regulatory Guide for Radiological Effluent Monitoring and Environmental Surveillance. Assistant Secretary for Environment, Safety and Health, U.S. Department of Energy, Washington, D.C.

DOE Order 231.1. "Environment, Safety, and Health Reporting."

DOE Order 5400.1. "General Environmental Protection Program."

DOE Order 5484.1. "Environmental Protection, Safety, and Health Protection Information Reporting Requirements."

DOE/RL-97-43. 1997. Radionuclide Air Emissions Report for the Hanford Site, Calendar Year 1996. B. P. Gleckler and L. P. Diediker, Waste Management Federal Services of Hanford, Inc., and S. J. Jette, K. Rhoads, and M. J. Sula, Pacific Northwest National Laboratory, Richland, Washington, for the U.S. Department of Energy, Richland Operations Office, Richland, Washington.

HNF-EP-0527-6. 1997. Environmental Releases for Calendar Year 1996. B. P. Gleckler, Waste Management Federal Services, Inc., Northwest Operations, Richland, Washington.

HNF-EP-0573-5. 1997. Hanford Site Near-Facility Environmental Monitoring Annual Report, Calendar Year 1996. C. J. Perkins, A. R. Johnson, B. M. Markes, S. M. McKinney, R. M. Mitchell, and R. K. Price, Fluor Daniel Hanford, Inc., Richland, Washington.

PNNL-1 1470. 1997. Hanford Site Groundwater Monitoring for Fiscal Year 1996. M. J. Hartman and P. E. Dresel (eds.), Pacific Northwest National Laboratory, Richland, Washington.

PNNL-11471. 1997. Hanford Site Climatological Data Summary 1996, With Historical Data. D. J. Hoitink and K. W. Burk, Pacific Northwest National Laboratory, Richland, Washington.

PNNL-11472. 1997. Hanford Site Environmental Report for Calendar Year 1996. R. L. Dirkes and R. W. Hanf (eds.), Pacific Northwest National Laboratory, Richland, Washington.

Resource Conservation and Recovery Act of 1976, as amended, Public Law 94-580, 90 Stat. 2795, 42 USC 6901 et seq.

State of Washington Department of Health. 1993. Environmental Radiation Program 1991 Annual Report, 30th Edition. Division of Radiation Protection, Olympia, Washington.

WAC 246-247, Washington Administrative Code. Radiation Protection - Air Emissions. Olympia, Washington. 


\title{
Hanford Site Environmental Monitoring Plan
}

\author{
Section II.A. Facility Effluent-Monitoring Plans
}

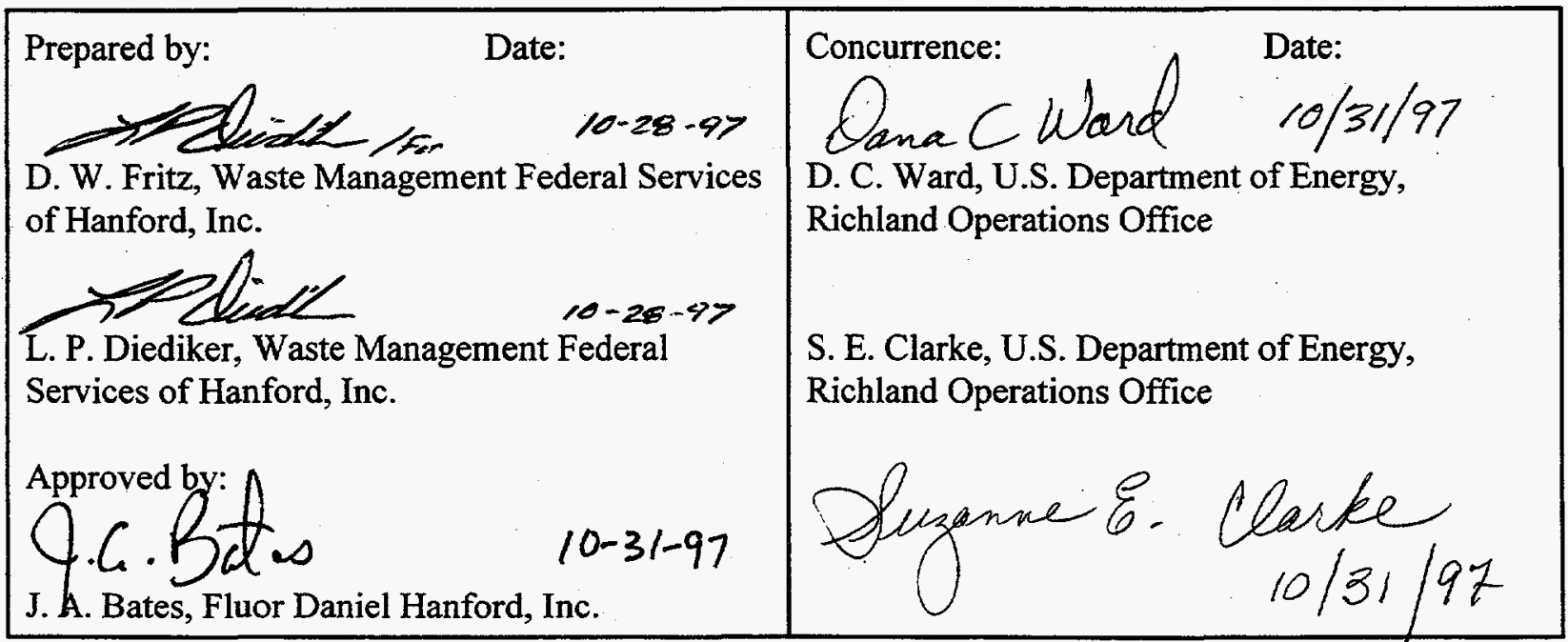




\section{Introduction}

This section addresses facility effluent-monitoring plans (FEMPs) that are completed and implemented to meet the overall radioactive and nonradioactive monitoring requirements of U.S. Department of Energy (DOE) Order 5400.1 and DOE/EH-0173T. New or modified facilities are evaluated to determine if a FEMP is needed; if so, a FEMP will be completed before startup.

Waste Management Federal Services of Hanford, Inc. has been contracted by Fluor Daniel Hanford, Inc. to maintain the FEMP guidance document (WHC-EP-0438-1) for use by Hanford Site contractors in preparing their facility-specific FEMPs. The FEMP management plan (WHC-EP-0491) describes the relationship of the FEMP to this overall Environmental Monitoring Plan and delineates the required contents and DOE and contractor relationships.

The effluent- and emission-monitoring activities for all media, with the exception of groundwater, are addressed by the FEMPs. The monitoring of liquid effluents for nonradioactive hazardous constituents, as defined by the Resource Conservation and Recovery Act of 1976 (RCRA), is covered in the sitespecific sampling analysis plan. Two activities associated with the FEMPs are the determination of the need for a FEMP and the preparation of the FEMP. The FEMP determination consists of an initial evaluation of potential radioactive or hazardous material sources within a facility. If a significant quantity of radioactive or hazardous material is present, then a FEMP is prepared.

\section{Determination of Need for a FEMP}

The FEMP determinations were prepared for the individual Hanford Site facilities. In many cases, facilities were grouped by area and the following information was included in each FEMP determination document: an introduction section that includes the current configuration and status of each facility. (active, inactive, standby, etc.); an information section that includes a brief facility/process description; a discussion section that includes source-term identification and characterization, radiological/hazardous material inventories at risk, fugitive sources (where applicable), identification of release pathway and effluent point of discharge, and identification and characterization of source terms contributing to each effluent stream; a section that describes the potential upset conditions (assuming failure of a single barrier) for each event, along with the type and amount of material involved, the pathway for potential release, and the offsite dose calculations to be evaluated against the Clean Air Act Amendments of 1990, Code of Federal Regulations, Title 40, Part 61 (40 CFR 61), Subpart H, and Washington Administrative Code (WAC) 173-480; a summary section that evaluates the relevant data to determine whether the facility requires a FEMP; and an attachment entitled "Determination of FEMP Requirement" from the guidance document (WHC-EP-0438-1).

\section{Radiological Emissions}

Pursuant to 40 CFR 61 and DOE Order 5400.1, a FEMP was prepared for those facilities having the potential to release quantities of airborne radioactive materials that could cause radiation doses in excess of $0.1 \mathrm{mrem} / \mathrm{yr}$ effective dose equivalent (EDE) to the maximally exposed individual. A FEMP was also 
prepared for any facility discharging a liquid effluent regulated by 40 CFR 122 and containing sufficient radionuclides to cause an EDE greater than $4.0 \mathrm{mrem} / \mathrm{yr}$ in any person exposed to the effluent. The release quantities were evaluated at the point of release, assuming no pollution-control equipment was in place but operations were otherwise normal (including expected upset conditions). In this determination process, over 160 potential sources across the Hanford Site were evaluated (e.g., WHC-EP-0498, PNL-10061).

Dose calculation methods and summaries of the FEMP determinations are given in WHC-EP-0498. The FEMP determinations are grouped by Hanford Site operational area and can be found in the following six documents: WHC-EP-0439, WHC-EP-0440, WHC-EP-0441, WHC-EP-0442, WHC-EP-0443, and PNL-10061.

\section{Nonradiological Emissions}

A FEMP was also prepared for any facility having the potential to release large quantities of nonradioactive hazardous materials (e.g., exceeding the reportable quantities listed in 40 CFR 302.4) and having no pollution-control equipment in place.

In addition to the FEMP, a sampling and analysis plan is required by RCRA for the monitoring of nonradioactive liquid effluent streams. These plans characterize liquid effluent discharges, account for variations in volumes and contaminant concentrations from operational practices, and consider all the parameters known or suspected to be associated with each liquid effluent stream, such as influence of operational practices, raw-water characteristics, and process knowledge. The results of data analysis are compared against the list of hazardous substances in WAC 173-200 to identify any exceedances and to ascertain compliance with regulations. The results are used to assess the potential for contamination in soils and groundwater.

This sampling complements the routine environmental monitoring program at the Hanford Site and allows analysis of the nonradioactive constituents in the liquid waste streams that are not included in other routine environmental monitoring programs.

Results of the sampling efforts are compiled and archived in the Liquid Effluent Monitoring Infor.mation System (LEMIS).

\section{FEMP Preparation}

Waste Management Federal Services of Hanford, Inc. has been contracted to coordinate FEMP activities for the Hanford Site contractors and transmits the results of the FEMP preparations to Fluor Daniel Hanford, Inc. for submittal to DOE Richland Operations Office (RL).

The FEMP determinations and the prepared FEMPs are retained by Waste Management Federal Services of Hanford, Inc. for Fluor Daniel Hanford, Inc. Pacific Northwest National Laboratory (PNNL) performs a similar function for the DOE facilities it manages. DOE-RL is informed in a timely manner of any changes to the FEMPs. 
DOE Order 5400.5 and DOE/EH-0173T require a quality assurance plan, covering all environmental monitoring activities at the Hanford Site, to be prepared consistent with applicable elements of The American Society of Mechanical Engineers (ASME) NQA-1. Further, QAMS-005/80 is applicable, and such quality assurance plan is included or referenced in each individual FEMP.

The quality assurance objectives for the monitoring of liquid effluents and air emissions are discussed in WHC-EP-0446-1. The quality assurance objectives for compiling and reporting air emission monitoring are defined in WHC-EP-0528-1.

The FEMPs are prepared in the format specified in WHC-EP-0438-1. Each FEMP includes the following: an introduction, including purpose, scope, and discussion of constituents and applicable regulations; a description of the facility, process, potential sources, and release pathways; a characterization of effluent discharges (both airborne and liquid) that are monitored and the potential contaminant concentrations; an identification and characterization of the effluent-discharge points (both airborne and liquid) and a discussion of the design criteria and technical specifications pertaining to the effluentmonitoring/-sampling systems; a discussion of monitoring and assessment methods different from those specified by the U.S. Environmental Protection Agency and the 5400-series of DOE Orders; historical monitoring/sampling data (if available) and a comparison of data for normal and upset conditions; information regarding sample analysis, including laboratory procedures; notification and reporting requirements; interface with the Groundwater Monitoring Project (managed by PNNL); a discussion of quality assurance; a discussion of internal and external reviews, approvals of changes, and annual reviews; a discussion of compliance with applicable DOE Orders and U.S. Environmental Protection Agency regulations; conclusions, exceptions or exemptions and justifications, and required system upgrades; and applicable references.

Table II.A-1 provides a listing of facilities on the Hanford Site, the prime contractor responsible for managing the facility, and the determination of a need for a FEMP. Because it is not feasible to include each individual FEMP in this Environmental Monitoring Plan, an abstract from each noted with a "yes" in Table II.A-1 follows.

Table II.A-1. Facilities Determination Results

\begin{tabular}{|c|c|c|}
\hline Facility & \multirow[t]{2}{*}{ Manager } & \multirow[t]{2}{*}{ FEMP Required? } \\
\hline 100 Areas & & \\
\hline KE/KW Fuel Storage Basins and Associated Facilities & FDH & Yes \\
\hline N Electrical Shop & $\mathrm{BHI}$ & no \\
\hline N Reactor & $\mathrm{BHI}$ & no \\
\hline N Paint Shop & $\mathrm{BHI}$ & no \\
\hline Retired Reactors (B, C, D, DR, F, H) & $\mathrm{BHI}$ & no \\
\hline \multicolumn{3}{|c|}{ 200/600 Areas } \\
\hline B Plant/Waste Encapsulation and Storage Facility & FDH & Yes \\
\hline Batch Plant & FDH & No \\
\hline Fabrication Shops & FDH & No \\
\hline General Area Services (200 Areas) & $\mathrm{FDH}$ & No \\
\hline
\end{tabular}


Table II.A-1. (contd)

\begin{tabular}{|c|c|c|c|c|c|c|}
\hline & & Facility & Manager & FE & P Requ & ed? \\
\hline Low-Level ] & ial Groun & & FDH & & No & \\
\hline Plutonium $\mathrm{F}$ & shing Plar & & FDH & & Yes & \\
\hline Plutonium- $\mathrm{C}$ & nium Extr & ction (PUREX) Plant & $\mathrm{FDH}$ & & Yes & \\
\hline PUREX Pip & Iter Shop & & $\mathrm{FDH}$ & & No & \\
\hline Solid Waste & cilities $\mathrm{Cc}$ & npactor & $\mathrm{FDH}$ & & No & \\
\hline T Plant & & & $\mathrm{FDH}$ & & No & \\
\hline Tank Farm & nplex & & & & & \\
\hline Single-S & 1 Tank Far & & & & & \\
\hline 241-A & 241-AX & 241-B & $\mathrm{FDH}$ & No & No & No \\
\hline 241-BX & 241-BY & $241-C$ & $\mathrm{FDH}$ & No & No & Yes \\
\hline $241-S$ & 241-SX & 241-TX & FDH & No & Yes & No \\
\hline 241-TY & $241-\mathrm{U}$ & & $\mathrm{FDH}$ & No & No & \\
\hline Double- & 11 Tank Fa & & & & & \\
\hline 241-AN & 241-AP & 241-AW & FDH & No & Yes & Yes \\
\hline 241-SY & 244-A & 244-TX & $\mathrm{FDH}$ & Yes & Yes & No \\
\hline $244-U$ & $244-S$ & 244-BX & FDH & Yes & Yes & Yes \\
\hline 241-AY & $241-\mathrm{AZ}$ & & $\mathrm{FDH}$ & Yes & Yes & \\
\hline Vaults & & & & & & \\
\hline 204-AR & 244-AR & 244-CR & FDH & No & Yes & Yes \\
\hline Evapora & & & & & & \\
\hline $242-A$ & $242-S$ & $242-\mathrm{T}$ & $\mathrm{FDH}$ & No & No & No \\
\hline U Plant/224 & $\mathrm{UO}_{3}$ & & $\mathrm{BHI}$ & & No & \\
\hline Uranium- $\mathrm{Tr}$ & ide $\left(\mathrm{UO}_{3}\right)$ & lant & FDH & & No & \\
\hline Waste Rece & ng and Pro & essing (WRAP) Facility & FDH & & Yes & \\
\hline Waste Sam & Ig and Che & acterization Facility (WSCF) & FDH & & No & \\
\hline 200 Areas $\mathrm{E}$ & uent Treat & nent Facility (ETF) & FDH & & No & \\
\hline 200 Areas T & ated Efflus & t Disposal Facility (TEDF) & FDH & & No & \\
\hline 200-E Dark & & & FDH & & No & \\
\hline 200-E Elect & al Shop & & $\mathrm{FDH}$ & & No & \\
\hline 200-W Pain & hop & & FDH & & No & \\
\hline 202-S (Red & ion-Oxida & on [REDOX] Plant) & $\mathrm{BHI}$ & & No & \\
\hline $\begin{array}{l}\text { 212-P Nonr } \\
\text { Facility }\end{array}$ & oactive $\mathrm{Pc}$ & ychlorinated Biphenyl Storage & FDH & & No & \\
\hline 222-S Labo & & & FDH & & Yes & \\
\hline 224-T Tran & anic Wast & Storage and Assay Facility & FDH & & No & \\
\hline 233-S Facil & & & $\mathrm{BHI}$ & & No & \\
\hline
\end{tabular}


Table II.A-1. (contd)

\begin{tabular}{|c|c|c|}
\hline Facility & Manager & FEMP Required? \\
\hline 242-B Facility & PNNL & No \\
\hline 284-E and 294-W Powerplants & FDH & No \\
\hline 2703-E Clinical Environmental Laboratory & $\mathrm{FDH}$ & No \\
\hline 2711-E Facility & FDH & No \\
\hline 2718-E Facility & PNNL & No \\
\hline 2911-E Facility & FDH & No \\
\hline Fitzner/Eberhardt Arid Lands Ecology Reserve (6652) & PNNL & No \\
\hline Purge Water Storage and Treatment Facility (600 Area) & FDH & No \\
\hline $213-\mathrm{J}$ and $213-\mathrm{K}$ Storage Vaults (600 Area) & FDH & No \\
\hline 616 Nonradioactive Dangerous Waste Storage Facility & FDH & No \\
\hline $622-D$ Facility & PNNL & No \\
\hline 622-R Facility & PNNL & No \\
\hline 622-S Facility & PNNL & No \\
\hline \multicolumn{3}{|l|}{300 Area } \\
\hline 300 Area Paint Shop & FDH & No \\
\hline 300 Area Treated Effluent Disposal Facility & FDH & No \\
\hline 300-N Facility & PNNL & No \\
\hline 303-A, B, C, E, F, G, K & FDH & No \\
\hline 303-J Facility & PNNL & No \\
\hline 303-M Oxide Facility & FDH & No \\
\hline 305-B Facility & PNNL & No \\
\hline 305 Hot Cell Verification & FDH & No \\
\hline 306-E Fabrication and Testing Laboratory & FDH & No \\
\hline 306-W Facility & PNNL & No \\
\hline 308 Fuels Laboratory & BHI & No \\
\hline 309 SP-100 Facility & FDH & No \\
\hline 313 and 333 Fuels Fabrication Facilities & FDH & No \\
\hline 314 Facility & PNNL & No \\
\hline 318 Trailer 5 & PNNL & No \\
\hline 320 Facility & PNNL & No \\
\hline 321 Facility & FDH & No \\
\hline 323 Facility & PNNL & No \\
\hline 324 Facility & $\mathrm{FDH}$ & Yes \\
\hline 325 Building & PNNL & Yes \\
\hline 326 Facility & PNNL & No \\
\hline
\end{tabular}


Table II.A-1. (contd)

\begin{tabular}{|c|c|c|}
\hline Facility & Manager & FEMP Required? \\
\hline 327 Facility & FDH & Yes \\
\hline 328 Technical Shops & FDH & No \\
\hline 329 Facility & PNNL & No \\
\hline 329 Neutron Multiplier Facility & PNNL & No \\
\hline 331 and 331-A Facility & PNNL & No \\
\hline 331-C Facility & PNNL & No \\
\hline 331-G Facility & PNNL & No \\
\hline 331-H Facility & PNNL & No \\
\hline 334-A Spent Acid Storage & $\mathrm{FDH}$ & No \\
\hline 335/335A Facility & $\mathrm{FDH}$ & No \\
\hline 337 High-Temperature Sodium Facility & $\mathrm{FDH}$ & No \\
\hline 338 Maintenance & $\mathrm{FDH}$ & No \\
\hline 340 Complex & FDH & Yes \\
\hline 377 Facility & $\mathrm{FDH}$ & No \\
\hline 382 Facility & FDH & No \\
\hline 384 Powerhouse & FDH & No \\
\hline 3621B/C/D Facility & FDH & No \\
\hline 3703 Facility & $\mathrm{FDH}$ & No \\
\hline 3704 Facility & FDH & No \\
\hline 3705 Photo Laboratory & FDH & No \\
\hline 3706 Facility & FDH & No \\
\hline 3707 Facility & FDH & No \\
\hline 3708 Facility & PNNL & No \\
\hline 3709 Paint Shop & FDH & No \\
\hline 3717-B Standards Laboratory & FDH & No \\
\hline 3718-F Alkali Metal & FDH & No \\
\hline 3720 Facility (Materials Science Laboratory) & PNNL & Yes \\
\hline 3722 Facility & FDH & No \\
\hline 3730 Facility & PNNL & No \\
\hline 3732 Facility & $\mathrm{FDH}$ & No \\
\hline 3745 Facility & PNNL & No \\
\hline 3765 Facility & FDH & No \\
\hline 3790 Facility & FDH & No \\
\hline
\end{tabular}


site operations that identifies activities responsible for radioactive releases that could cause a radiation exposure to the public and/or environment, and 4) an overall procedure for analyzing existing and proposed operations and activities to ensure ALARA is practiced. Further, the program will be designed to identify general areas to be considered in environmental ALARA decisions (e.g., societal, technological, economic, public policy). A checklist of evaluation factors, staff requirements, and required records, in addition to the programs already in place on the Hanford Site, will be developed. Fluor Daniel Hanford, Inc., Bechtel Hanford, Inc. and PNNL each have the responsibility to prepare an environmental ALARA program plan.

\section{Potential Unmitigated Doses from Hanford Facilities}

Sources of, and potential radiation doses from, airborne releases from Hanford Site facilities are calculated to determine whether a radiation release could result in a dose to the maximally exposed individual of $>0.1 \mathrm{mrem} / \mathrm{yr}$ EDE. A FEMP is needed for any facility that exceeds this dose level. These determinations are documented and updated on a regular basis. PNNL determinations are calculated from a comprehensive inventory of radionuclides (PNL-10061 describes the method used). Fluor Daniel Hanford, Inc. and Bechtel Hanford, Inc. determinations are performed and documented in WHC-EP-0498, which is currently in revision.

\section{FEMP Abstracts}

The FEMPs prepared for the affected facilities given in Table II.A-1 are summarized on the following pages. 


\section{KE and KW Fuel-Storage Basins}

These fuel-storage basins are located in the 100-K Area adjacent to the Columbia River. The $\mathrm{KE}$ and KW Reactors have been shut down, deactivated, and decommissioned. Most of the stored fuel from the $\mathrm{KE}$ and KW Reactors was shipped to the 200-East Area reprocessing facilities. After initial laying away, the fuel-storage basins (located inside the 105-KE and 105-KW Buildings) were cleaned and modified for storing $\mathrm{N}$ Reactor irradiated fuel. The basin-cooling systems were modified to a closed system, and a leak in the KE basin was repaired. Storage of $\mathrm{N}$ Reactor fuel in the basins started in 1975 and continues to the present, but shipments from the reactor ceased in 1989. Monitoring of the groundwater adjacent to the basins for leak-detection purposes is conducted under the Groundwater Monitoring Project managed by PNNL. This FEMP also covers the 1706-KE and 1706-KER Engineering Laboratories, 1908-KE Outfall (i.e., National Pollutant Discharge Elimination System [NPDES] Outfall 004), and 181-KE Filter Screen Backwash Discharge (i.e., NPDES Outfall 003). This last facility does not release hazardous materials in excess of U.S. Environmental Protection Agency standards.

\section{Airborne Effluents}

Airborne effluent streams considered include those from the KE and KW Fuel-Storage Basins, 1706-KE and 1706-KER Engineering Laboratories, and 1706-KER Water Studies Recirculation Building. Radionuclides discharged to the air include ${ }^{60} \mathrm{Co},{ }^{90} \mathrm{Sr},{ }^{134} \mathrm{Cs},{ }^{137} \mathrm{Cs},{ }^{238} \mathrm{Pu},{ }^{239} \mathrm{Pu}$, and ${ }^{240} \mathrm{Pu}$.

\section{Liquid Effluents}

One liquid stream located at the 1908-KE Outfall (i.e., NPDES Outfall 004) and routinely sampled was determined to have a low-to-remote potential to exceed the drinking water standard (40 CFR 141) or contain radionuclide constituents specified in DOE Order 5400.5. Radionuclides in this stream, including tritium, ${ }^{60} \mathrm{Co},{ }^{90} \mathrm{Sr},{ }^{137} \mathrm{Cs},{ }^{239} \mathrm{Pu}$, and ${ }^{240} \mathrm{Pu}$, are discharged to the Columbia River.

\section{FEMP Determination}

A FEMP is required for the KE and KW Fuel-Storage Basins because of the potential for liquid effluents from the 1908-KE Outfall (i.e., NPDES Outfall 004) to contain radionuclide constituents specified in DOE Order 5400.5 or to exceed the 4-mrem/yr drinking water standard. The FEMP (WHC-EP-0497, Rev. 2) was issued in August 1996. 


\section{B Plant/Waste Encapsulation and Storage Facility}

B Plant is located in the 200-East Area. The plant was originally designed to chemically process spent nuclear fuels but was later modified to individually separate strontium and cesium from the plutonium-uranium extraction (PUREX) fission product waste stream. The cesium and strontium were then encapsulated at the Waste Encapsulation and Storage Facility, and the remaining waste was transferred to the tank farms. B Plant is a permitted treatment, storage, and disposal facility currently operating under interim status with an approved Part A permit. Currently, B Plant is a facility being prepared for shutdown. Its sole mission is to support the safe management and storage of its residual radionuclide inventory. There are currently no production activities at B Plant, but there are several operating systems required to accomplish the current mission. B Plant receives and stores various chemicals from commercial suppliers for treatment of low-level waste generated at the Waste Encapsulation and Storage Facility and for conditioning of water used in heating, ventilating, and air conditioning units.

The current Waste Encapsulation and Storage Facility mission is to receive and store the cesium and strontium capsules in a safe manner and in compliance with all applicable rules and regulations. There are currently no production activities at the Waste Encapsulation and Storage Facility, but there are several operating systems required to accomplish the current mission (e.g., receiving and storing various chemicals from commercial suppliers for conditioning of water used in the heating, ventilating, and air conditioning units).

\section{Airborne Effluents}

Airborne effluent streams from B Plant include those from the 291-B-1, 296-B-5 (closed), and 296-B-13 (closed) Stacks; 296-B-21 through -27 Gallery Exhausters; bulk chemical-storage tank vents; and aqueous makeup tank vents. The 291-B-1 Stack has a real-time monitor. Radionuclide constituents of interest include ${ }^{90} \mathrm{Sr}$ and ${ }^{137} \mathrm{Cs}$.

Airborne effluent streams from the Waste Encapsulation and Storage Facility include those from the 296-B-10 Stack, 296-B-12 Emergency Jet (inactive, soon to be removed), and aqueous makeup tank vents. The $296-\mathrm{B}-10$ Stack has a real-time monitor. Radionuclide constituents of interest include ${ }^{90} \mathrm{Sr}$ and ${ }^{137} \mathrm{Cs}$.

\section{Liquid Effluents}

The liquid effluent streams at B Plant include steam condensate (currently inactive), process condensate (currently inactive), chemical sewer (currently inactive), combined cooling water (currently inactive), sanitary sewer systems, and french drains.

The liquid effluent streams from the Waste Encapsulation and Storage Facility include the former B Plant chemical sewer, cooling water, sanitary sewer, and french drains. The chemical sewer and cooling water streams have real-time $\mathrm{pH}$ and flow monitors.

\section{FEMP Determination}

A FEMP is required because of the potential for radionuclide concentrations in the airborne effluents from the 291-B-1 and 296-B-10 Stacks to cause a dose to the maximally exposed individual $>0.1 \mathrm{mrem} / \mathrm{yr}$ EDE. The FEMP (HNF-EP-0467-2) was issued in November 1997. 


\section{Plutonium Finishing Plant}

This plant is located in the 200-West Area and consists of one primary processing facility and several ancillary buildings (i.e., 234-5Z, 236-Z, 231-Z, 232-Z, 241-Z, 242-Z, 243-Z, 270-Z, 291-Z, 2736-Z, 2736-ZA, and 2736-ZB). Hazardous material inventories include acetone, carbon tetrachloride, oxides of nitrogen, hydrogen chloride, hydrochloric acid, and nitric acid. Radionuclide inventories include ${ }^{90} \mathrm{Sr}$, ${ }^{137} \mathrm{Cs},{ }^{238} \mathrm{Pu},{ }^{239} \mathrm{Pu},{ }^{241} \mathrm{Pu}$, and ${ }^{241} \mathrm{Am}$.

\section{Airborne Effluents}

One gaseous effluent stream (291-Z-1 Stack), which has a real-time monitor, was determined to require a FEMP based on the potential for the calculated EDE to the maximally exposed individual to exceed $0.1 \mathrm{mrem} / \mathrm{yr}$.

\section{Liquid Effluents}

One liquid effluent stream (216-Z-20 Crib) was discontinued in 1995.

\section{FEMP Determination}

A FEMP is required for the Plutonium Finishing Plant because of the potential for radionuclide concentrations in airborne effluents from the 291-Z-1 Stack to cause a dose to the maximally exposed individual >0.1 mrem/yr EDE. The FEMP (HNF-EP-0476-2) was issued in November 1997. 


\section{Plutonium-Uranium Extraction (PUREX) Plant}

The PUREX Plant is located in the 200-East Area and is a collection of buildings and facilities for the processing by chemical separation of irradiated fuel elements for use in nuclear weapons production. The primary components of the plant are the 202-A Building (main canyon building) in which fuels were reprocessed, 203-A Pumphouse and Tank Farm, 211-A Pumphouse and Tank Farm, 206-A Acid Fractionator Building, 291-AE Building, 293-A Building (backup facility), effluent-monitoring buildings, and railroad tunnel. The plant has been deactivated (i.e., prepared for long-term, safe, unstaffed surveillance).

\section{Airborne Effluents}

The PUREX Plant is the source of one active, principal, airborne effluent stream (i.e., 291-A-1 Stack). Gaseous effluents continue to be discharged during its deactivation mode to provide control of trace quantities of contamination. The stack has the potential to exceed 40 CFR 61, Subpart H criteria requiring continuous emissions measurement and will require selective air monitoring for ${ }^{239,240} \mathrm{Pu}$ and ${ }^{241} \mathrm{Am}$.

\section{Liquid Effluents}

All liquid effluent streams have been eliminated.

\section{FEMP Determination}

A FEMP is required for the PUREX Plant because of the potential for radionuclide concentrations in the airborne effluent from the 291-A-1 Stack to cause a dose to the maximally exposed individual $>0.1 \mathrm{mrem} / \mathrm{yr}$ EDE. The FEMP will be reissued by Bechtel Hanford, Inc. after transition from Fluor Daniel Hanford, Inc. 


\section{Tank Farm Complex}

The tank farm complex is located within the 200-East and 200-West Areas. A total of 177 singleshell and double-shell tanks with transfer, receiving, and treatment facilities make up the complex. Major components evaluated for the FEMP include the single- and double-shell tank farms, 204-AR Unloading Station, 244-CR Vault, double-contained receiver tanks, and waste transfer lines. No upset scenarios considered for the transfer lines would produce a release requiring a FEMP. Chemical constituents include iron(III) hydroxide, sodium aluminate, sodium carbonate, sodium hydroxide, sodium nitrate, sodium nitrite, sodium phosphate, sodium sulfate, and various organic compounds. Radionuclides include ${ }^{14} \mathrm{C},{ }^{63} \mathrm{Ni},{ }^{90} \mathrm{Sr},{ }^{93} \mathrm{Zr},{ }^{99} \mathrm{Tc},{ }^{106} \mathrm{Ru},{ }^{126} \mathrm{Sn},{ }^{129} \mathrm{I},{ }^{135} \mathrm{Cs},{ }^{137} \mathrm{Cs},{ }^{151} \mathrm{Sm},{ }^{226} \mathrm{Ra},{ }^{230} \mathrm{Th},{ }^{233} \mathrm{U},{ }^{234} \mathrm{U},{ }^{235} \mathrm{U}$, ${ }^{237} \mathrm{~Np},{ }^{238} \mathrm{U},{ }^{238} \mathrm{Pu},{ }^{239} \mathrm{Pu},{ }^{240} \mathrm{Pu},{ }^{241} \mathrm{Pu},{ }^{241} \mathrm{Am},{ }^{243} \mathrm{Am}$, and ${ }^{244} \mathrm{Cm}$.

\section{Airborne Effluents}

Sixteen stacks were identified in the stack source assessment (WHC-EP-0894) and each requires a FEMP, based on the calculated potential for each stack of $>0.1 \mathrm{mrem}$ EDE to the maximally exposed offsite individual.

\section{Liquid Effluents}

The liquid effluents include those from the 241-AY/AZ Tank Farm steam coil condensate to 216-A-8 Crib, 241-A Tank Farm surface condenser cooling water to the 216-B-3 Pond, 241-SX Tank Farm sludge cooler to the 216-S-25 Crib, and 244-AR Vault coolant water to the 216-B-3 Pond. These effluents are routinely sampled.

\section{FEMP Determination}

A FEMP is required for the tank farm complex because of the potential for radionuclide concentrations in airborne effluents from each of several stacks to cause a dose to the maximally exposed individual >0.1 mrem/yr EDE. The FEMP (HNF-EP-0479-1) was updated in 1997. 


\section{Waste Receiving and Processing Facility (Module 1)}

This facility is located in the 200-West Area and is housed in the 2336-W Building just north of the Central Waste Complex. The facility is a metal building, consisting of preinsulated, prefinished metal, interlocking roof, and wall sandwich panels. The facility will become operational in the fall of 1997 and provide waste processing; shipping and receiving; mechanical, electrical, heating, ventilating, and cooling rooms; as well as administrative areas.

\section{Airborne Effluents}

The gaseous effluent-monitoring/-sampling system operates to collect near-isokinetic samples for compliance with 40 CFR 61, Subpart $\mathrm{H}$ and WAC 246-247. The stack has sample probes that divert a. representative sample of the exhaust stream via transport tubing to the sampling/monitoring cabinet. 'The transport lines are heat traced to prevent condensation within the tubing. A record sampler inside the sampling/monitoring cabinet collects a sample for laboratory analysis. A continuous air monitor scans the sample for alpha/beta contamination that exceeds concentration limits. The stack also houses a temperature probe and a velocity probe. The flow through the systems is established and maintained by vacuum pumps and is measured by flow-measuring sensors.

\section{Liquid Effluents}

The facility is equipped with a TRUPACT-II (transuranic package transporter) loading and unloading bay with a full-length floor drain to divert melting snow and ice to the proper disposal location. The TRUPACT bay also has potable water for hosing off vehicles. The drain runs out of the east side of the facility to a sand interceptor. From the sand interceptor, the stream is discharged to a gravel drain basin. The discharge stream from the TRUPACT bay has been listed in the site inventory of miscellaneous streams. The sludge that accumulates in the drain is sampled for hazardous and radioactive constituents, and any liquid is sampled for hazardous and radioactive material during clean out.

The facility has a mechanical room that houses two compressors, an air dryer, several pumps, and a domestic water heater. The condensate that builds up in the compressor is combined with the air dryer condensate and discharged to a gravel basin on the north side of the facility. The condensate passes through an oil/water separator prior to discharge to the environment. The effluent will be periodically sampled, pending the establishment of State of Washington Department of Ecology guidelines on sampling and analysis.

\section{FEMP Determination}

The estimated potential hazardous material quantities do not exceed their respective 40 CFR 302 reportable quantities on a $24-\mathrm{h}$ basis. Therefore, no federal, state, and local effluent regulations, as well as DOE Orders, require any special regulated material-monitoring requirements. However, the potential EDE for radioactive constituents does exceed the continuous emission measurement criteria listed in 40 CFR 61, Subpart H. Therefore, full compliance is required and a FEMP (HNF-EP-0885, Rev. 1) was issued in 1997. 


\section{2-S Laboratory}

The 222-S Laboratory complex is located in the 200-West Area. The laboratory complex provides analytical and radiological chemistry services for the Hanford Site. The principal components include the 222-S Main Laboratory, 222-SA Laboratory (nonradioactive standards and "cold" process development), 2716-S Storage Facility, 222-S Annex, 207-SL Retention Basin, 219-S Waste Handling Facility, 222-SD Solid Waste Handling and Storage System, 222-SC Filter Building, 222-SB Filter Building, 218-W-7 Dry Waste Burial Vault, and 216-S-26 Crib. Because of the nature of the laboratory complex, the inventories of both radionuclides and hazardous materials are extensive.

\section{Airborne Effluents}

Calculations and real-time monitoring show no gaseous effluent streams that would exceed 40 CFR 61, Subpart H criteria.

\section{Liquid Effluents}

Three liquid effluent streams, all of which have real-time monitors, were identified as requiring a FEMP based on their potential for releasing hazardous waste under upset conditions. The facilities from which these streams originate include the 207-SL Retention Basin (part of 222-S), 222-SA Laboratory, and 219-S Waste Handling Facility.

\section{FEMP Determination}

A FEMP is required for the 222-S Laboratory because of the potential, during upset conditions, for liquid effluents from each of the three liquid effluent streams to exceed the reportable quantity in 40 CFR 302. The FEMP (HNF-EP-0480-2) was updated in 1997. 


\section{Facility}

The 324 Facility in the 300 Area primarily supports the research and development of radioactive and nonradioactive waste vitrification technologies (i.e., ceramic melters, in situ vitrification, and Hanford Waste Vitrification Program design support), biological waste remediation technologies, spent nuclear fuel studies, waste mixing and transport studies, and tritium development programs. All of the abovementioned programs deal with and have the potential to release hazardous and/or radioactive material. The potential for discharge would primarily result from 1) conduct of research activities using the hazardous materials, 2) storage of radionuclides and hazardous chemicals, 3) archive storage of programmatic samples, and 4) waste accumulation and storage.

\section{Airborne Effluents}

Potential radioactive airborne effluents in the 324 Facility have been characterized, and all release pathways have been verified. Stack monitors (samplers) were upgraded to meet 40 CFR 61 criteria. The primary stack (EP-324-01-S) is currently registered with the State of Washington as required by WAC 246-247. Potential nonradioactive airborne effluents have been characterized for compliance with WAC 173-401 (i.e., the air operating permit regulations) and a permit is expected to be issued in February 1998.

\section{Liquid Effluents}

This facility discharges to four sewer systems (radioactive liquid waste system, retention process sewer, process sewer, and sanitary sewer). Liquid effluent releases are either administratively or physically controlled. Most connections to the process sewer that have the potential to release regulated effluent have been plugged. Floor and sump drains have been modified with standpipes to prevent uncontrolled discharge. Selected floor drains in facility service tunnels that must remain open in the event of main service line leaks or ruptures are posted to control liquid effluent disposal. Verification of the radioactive liquid waste system, retention process sewer, and process sewer liquid effluent lines is proceeding as part of an ongoing program. Liquid effluent lines from the facility enter the 300 Area liquid effluent system. This system is monitored before release to the environment. The radioactive liquid waste system is not released to the environment but is transferred to the 340 Complex and then to the 200 Area tank farms.

A sampling program for liquid effluents from this facility is under way. Liquid effluent-monitoring instruments are being installed, including a flow-proportional liquid sampler, in-line $\mathrm{pH}$ meter, and conductivity meter. Sampling of the liquid effluents will commence when the samplers are installed.

\section{FEMP Determination}

An inventory-based method was used to estimate the maximum potential offsite dose if airborne releases from the facility were unmitigated. The projected unmitigated dose met the criterion $(>0.1 \mathrm{mrem} / \mathrm{yr}$ EDE) for preparing a FEMP. A list of chemicals in the facility was obtained; chemicals in greater-than-reportable quantities were identified to characterize the potential for emissions of nonradioactive hazardous materials. The FEMP (PNL-MA-660) was updated in 1994. 


\section{Building}

This building (the Applied Chemistry Laboratory) in the 300 Area houses radiochemistry research, radioanalytical service, radiochemical process development, and hazardous and mixed hazardous wastetreatment activities. The laboratories and specialized facilities enable work, ranging from that with nonradioactive materials to that with picogram-to-kilogram quantities of fissionable materials and up to megacurie quantities of other radionuclides. The special facilities include two shielded hot cell areas that provide for process development or analytical chemistry work with highly radioactive materials and a waste-treatment facility for processing hazardous, mixed, low-level, and transuranic wastes.

Radioactive material storage and usage occur throughout the building and include a large number of isotopes. This material is in several forms, including solid, liquid, particulate, and gaseous. Some of these materials are also heated during testing.

\section{Airborne Effluents}

Potential radioactive airborne effluents have been characterized, and all release pathways have been verified. Stack monitors (samplers) were upgraded to meet 40 CFR 61 criteria. The primary stack (EP-325-01-S) is currently registered with the State of Washington Department of Health as required by WAC 246-247. Potential nonradioactive airborne effluents have been characterized for compliance with WAC 173-401 (i.e., the air operating permit regulations) and a permit is expected to be issued in February 1998.

\section{Liquid Effluents}

Liquid effluent release pathways are either administratively or physically controlled. Most connections to the process sewer that have the potential to release regulated effluents have been plugged. The remaining drains (primarily laboratory sink and hood drains) have been posted with labels identifying the type of drain and liquid effluent-disposal controls.

This building has three liquid effluent systems (i.e., radioactive liquid waste system, retention process sewer, and sanitary sewer). Because of the age of the building and the out-of-date drawings, some lines were found to be labeled (and used) inappropriately during liquid effluent line verification. Modifications were completed as soon as the lines were correctly identified. The retention process sewer and radioactive liquid waste system lines from the building enter the 300 Area liquid effluent system. The system is monitored before release to the environment. The radioactive liquid waste system is not released into the environment but is transferred to the 340 Complex and then to the 200 Area tank farms.

Liquid effluent-monitoring instruments, including a flow-proportional liquid sampler, in-line $\mathrm{pH}$ meter, and conductivity meter, are maintained for sampling in response to potential concerns at the 300 Area Treated Effluent Disposal Facility.

\section{FEMP Determination}

An inventory-based method was used to estimate the maximum potential offsite dose if airborne releases from the building were unmitigated. The projected unmitigated dose met the criterion $(>0.1 \mathrm{mrem} / \mathrm{yr}$ EDE) for preparing a FEMP. A list of chemicals in the building was obtained; chemicals in greater-than-reportable quantities were identified to characterize the potential for emissions of nonradioactive hazardous materials. The FEMP (PNL-MA-661) was updated in 1994. 


\section{Facility}

The 327 Facility in the 300 Area provides office and laboratory space for scientific and engineering staff who conduct multidisciplinary research in the areas of postirradiated fuels and structural materials. The building is designed to accommodate the use of radioactive and hazardous materials in the conduct: of these research activities.

\section{Airborne Effluents}

The potential radioactive airborne effluents from this facility have been characterized, and all release pathways have been verified. Stack monitors (samplers) were upgraded to meet 40 CFR 61 criteria. Two stacks (EP-327-01-S and EP-327-02-V) are currently registered with the State of Washington Department of Health as required by WAC 246-247. Potential nonradioactive airborne effluents have been characterized for compliance with WAC 173-401 (i.e., the air operating permit regulations) and a. permit is expected to be issued in February 1998.

\section{Liquid Effluents}

This facility discharges liquid effluents to four sewer systems (i.e., radioactive liquid waste system, retention process sewer, process sewer, and sanitary sewer). Liquid effluent releases are either administratively or physically controlled. Most connections to the process sewer that have the potential to release regulated effluent have been plugged; the remaining (primarily laboratory sink and hood drains) have been posted with labels identifying the type of drain and liquid effluent-disposal instructions. Floor and sump drains have been modified with standpipes to prevent uncontrolled discharge. Selective floor drains in facility service tunnels that must remain open in the event of main service line leaks or ruptures are also posted to control disposal of liquid effluents. Verification of the liquid effluent lines is nearing completion.

Liquid effluent lines from the facility enter the 300 Area liquid effluent system. The retention process sewer, process sewer, and sanitary sewer are monitored before release to the environment. The radioactive liquid waste system is not released to the environment but is transferred to the 340 Complex and then to the 200 Area tank farms.

A program to characterize the liquid effluents from this facility is under way. Liquid effluentmonitoring instruments are being installed, including a flow-proportional liquid sampler, in-line $\mathrm{pH}$ meter, and conductivity meter. Sampling the liquid effluents will commence when the samplers are installed.

\section{FEMP Determination}

An inventory-based method was used to estimate the maximum potential offsite dose if airborne releases from the building were unmitigated. The projected unmitigated dose met the criterion $(>0.1 \mathrm{mrem} / \mathrm{yr}$ EDE) for preparing a FEMP. A list of chemicals in the building was obtained; chemicals in greater-than-reportable quantities were identified to characterize the potential for emissions of nonradioactive hazardous materials. The FEMP (PNL-MA-662) was updated in 1994. 


\section{Complex}

The 340 Complex is located in the 300 Area near the Columbia River. Buildings that can discharge waste directly into the 340 Complex include $324,325,326,327$, and 329 . Wastes from other facilities can be transferred to the complex via 208-L (55-gal) drums, carboys, or other containers to a floor sump in the 340 Building. Two waste streams are managed by the 340 Complex, the radioactive liquid waste system and the retention process sewer. Inventories of both radionuclides and hazardous materials are extensive and are itemized in the FEMP.

\section{Airborne Effluents}

The radioactive liquid waste system, which has real-time monitors, has the potential to release gaseous/ particulate radioactive contaminants to the atmosphere. The system receives wastes from several sources and stores the wastes in one of the two belowground 56,775-L (15,000-gal) storage tanks. The stored waste is then transported quarterly to the 204-AR Unloading Facility in the 200-East Area for long-term storage/disposal.

\section{Liquid Effluents}

The retention process sewer receives potentially radioactive liquid effluents. The liquid effluents from this sewer are monitored for gross beta and gamma radiation with real-time monitoring instruments. If radiation is not detected, the waste stream is disposed to the soil column via an unlined trench. The disposal to the soil column was eliminated in January 1995 and the waste stream diverted to the 300 Area Treated Effluent Disposal Facility.

\section{FEMP Determination}

A FEMP is required for the 340 Complex because of the potential for radionuclides in airborne emissions stacks to cause a dose to the maximally exposed individual $>0.1-\mathrm{mrem} / \mathrm{yr}$ EDE. The FEMP (HNF-EP-0469-2) was issued in 1997. 


\section{Facility}

This facility (the Materials Science Laboratory) provides office and laboratory space for scientific and engineering staff who conduct multidisciplinary research in the areas of materials characterization and testing and waste management. The facility is designed to accommodate the use of radioactive and hazardous materials in the conduct of these activities.

Chemical storage and usage are well dispersed throughout the facility and consist of bulk materials (solvents, acids/bases), specimen materials used in materials characterization (e.g., beryllium alloys), substrate materials used in the conduct of laboratory experiments (e.g., chelating agents, nitrate, chromium and arsenic salts, inorganic oxides), and standards used for instrument calibration. A number of environmental or fabricated materials (i.e., grouts, coal, asphalts) are used in the conduct of leaching experiments or materials-testing activities.

\section{Airborne Effluents}

Potential radioactive airborne effluents in the 3720 Facility have been characterized, and all release pathways have been verified. Stack monitors (samplers) were upgraded to meet 40 CFR 61 criteria. The primary stack at the 3720 Facility (EP-3720-01-S) is currently registered with the State of Washington Department of Health as required by WAC 246-247. Potential nonradioactive airborne effluents have been characterized for compliance with WAC 173-401 (i.e., the air operating permit regulations) and a permit is expected to be issued in February 1998.

\section{Liquid Effluents}

This facility discharges to the process sewer and the sanitary sewer. Liquid effluent releases are either administratively or physically controlled. Most connections to the process sewer that had the potential to release regulated effluent have been plugged; the remaining (primarily laboratory sink and hood drains) have been posted with labels identifying the type of drain and liquid effluent-disposal controls.

Process sewer effluent lines from the facility enter the 300 Area Treated Effluent Disposal Facility. Sanitary sewer effluent lines from the facility join with the sanitary sewer lines from other 300 Area facilities and enter the City of Richland's publicly owned treatment works. Liquids in the process and sanitary sewers are treated and monitored before release to the environment. Results of the program are documented in PNNL-11552. Liquid effluent-monitoring instruments, including a flow-proportional liquid sampler, in-line $\mathrm{pH}$ meter, and conductivity meter, are maintained for sampling in response to potential concerns at the 300 Area Treated Effluent Disposal Facility.

\section{FEMP Determination}

An inventory-based method was used to estimate the maximum potential offsite dose if airborne releases from the building were unmitigated. The projected unmitigated dose met the criterion $(>0.1 \mathrm{mrem} / \mathrm{yr}$ EDE) for preparing a FEMP. A list of chemicals in the facility was obtained; chemicals in greater-than-reportable quantities were identified to characterize the potential for emissions of nonradioactive hazardous materials. The FEMP (PNL-MA-663) was updated in 1994. 


\section{References}

ASME (The American Society of Mechanical Engineers) NQA-1-1989 Edition. 1989. Quality Assurance Program Requirements for Nuclear Facilities, An American National Standard. New York.

Clean Air Act Amendments of 1990, Public Law 101-549, 42 USC 7401-7671Q.

(Draft) 10 CFR 834, Code of Federal Regulations, Title 10, Part 834. Radiation Protection of the Public and the Environment: Proposed Rule. 58 FR 56:16268-16322, March 25, 1993.

40 CFR 61, Code of Federal Regulations, Title 40, Part 61, Subpart H. National Emission Standards for Emissions of Radionuclides Other Than Radon From Department of Energy Facilities.

40 CFR 122, Code of Federal Regulations, Title 40, Part 122. EPA Administered Permit Programs: The National Pollutant Discharge Elimination System.

40 CFR 141, Code of Federal Regulations, Title 40, Part 141. National Primary Drinking Water Standards.

40 CFR 302, Code of Federal Regulations, Title 40, Part 302. Designation, Reportable Quantities, and Notification.

DOE/EH-0173T. 1991. Environmental Regulatory Guide for Radiological Effluent Monitoring and Environmental Surveillance. Assistant Secretary for Environment, Safety and Health, U.S. Department of Energy, Washington, D.C.

DOE Order 5400.1. "General Environmental Protection Program.”

DOE Order 5400.5. "Radiation Protection of the Public and the Environment."

HNF-EP-0467-2. 1997. Facility Effluent Monitoring Plan for the B Plant/Waste Encapsulation and Storage Facility. B\&W Hanford Company, Richland, Washington.

HNF-EP-0469-2. 1997. Facility Effluent Monitoring Plan for the 340 Waste Handling Facility. Waste Management Federal Services of Hanford, Inc., Richland, Washington.

HNF-EP-0476-2. 1997. Facility Effluent Monitoring Plan for the Plutonium Finishing Plant. B\&W Hanford Company, Richland, Washington.

HNF-EP-0479-1. 1997. Facility Effluent Monitoring Plan for the Tank Farms. Lockheed Martin Hanford Corporation, Richland, Washington.

HNF-EP-0480-2. 1997. Facility Effluent Monitoring Plan for the 222-S Laboratory. Waste Management Federal Services of Hanford, Inc., Richland, Washington.

HNF-EP-0885, Rev. 1. 1997. Facility Effluent Monitoring Plan for the Waste Receiving and Processing Facility. Waste Management Federal Services of Hanford, Inc., Richland, Washington. 
PNL-10061. 1994. Pacific Northwest Laboratory Facilities Radionuclide Inventory Assessment CY 199.21993. M. J. Sula and S. J. Jette, Pacific Northwest Laboratory, Richland, Washington.

PNL-MA-660. 1994. Facility Monitoring Plan for the 324 Facility. Pacific Northwest Laboratory, Richland, Washington.

PNL-MA-661. 1994. Facility Monitoring Plan for the 325 Facility. Pacific Northwest Laboratory, Richland, Washington.

PNL-MA-662. 1994. Facility Monitoring Plan for the 327 Facility. Pacific Northwest Laboratory, Richland, Washington.

PNL-MA-663. 1994. Facility Monitoring Plan for the 3720 Facility. Pacific Northwest Laboratory, Richland, Washington.

PNNL-11552. 1997. Characterization and Monitoring of 300 Area Facility Liquid Waste Streams During 1994 and 1995. C. J. Thompson, M. Y. Ballinger, E. G. Damberg, and R. G. Riley, Pacific Northwest National Laboratory, Richland, Washington.

QAMS-005/80. 1983. Interim Guidelines and Specifications for Preparation of Quality Assurance Project Plans. Office of Exploratory Research, U.S. Environmental Protection Agency, Washington, D.C.

Resource Conservation and Recovery Act of 1976, as amended, Public Law 94-580, 90 Stat. 2795, 42 USC 6901 et seq.

WAC 173-200, Washington Administrative Code. Water Quality Standards for Ground Waters of the State of Washington. Olympia, Washington.

WAC 173-401, Washington Administrative Code. Operating Permit Regulation. Olympia, Washington.

WAC 173-480, Washington Administrative Code. Ambient Air Quality Standards and Emission Limits for Radionuclides. Olympia, Washington.

WAC 246-247, Washington Administrative Code. Radiation Protection - Air Emissions. Olympia, Washington.

WHC-EP-0438-1. 1992. A Guide for Preparing Hanford Site Facility Monitoring Plans. Westinghouse Hanford Company, Richland, Washington.

WHC-EP-0439. 1991. Facility Effluent Monitoring Plan Determinations for the 100 Area Facilities. Westinghouse Hanford Company, Richland, Washington.

WHC-EP-0440. 1991. Facility Effluent Monitoring Plan Determinations for the 200 Areas Facilities. Westinghouse Hanford Company, Richland, Washington.

WHC-EP-0441. 1991. Facility Effluent Monitoring Plan Determinations for the 300 Area Facilities. Westinghouse Hanford Company, Richland, Washington. 
WHC-EP-0442. 1991. Facility Effluent Monitoring Plan Determinations for the 400 Area Facilities. Westinghouse Hanford Company, Richland, Washington.

WHC-EP-0443. 1991. Facility Effluent Monitoring Plan Determinations for the 600 Area Facilities. Westinghouse Hanford Company, Richland, Washington.

WHC-EP-0446-1. 1994. Quality Assurance Project Plan for Facility Effluent Monitoring Plan Activities. Westinghouse Hanford Company, Richland, Washington.

WHC-EP-0491. 1991. Management Plan for Facility Effluent Monitoring Plan Activities. Westinghouse Hanford Company, Richland, Washington.

WHC-EP-0497, Rev. 2. 1996. Facility Effluent Monitoring Plan for K Area Fuel Storage Basins: Westinghouse Hanford Company, Richland, Washington.

WHC-EP-0498. 1991. Unit Dose Calculation Methods and Summary of Facility Effluent Monitoring Plan Determinations. Westinghouse Hanford Company, Richland, Washington.

WHC-EP-0528-1. 1996. Quality Assurance Project Plan for Radioactive Airborne Emissions Data Compilation and Reporting. Westinghouse Hanford Company, Richland, Washington.

WHC-EP-0894. 1995. Hanford Site Radionuclide National Emission Standards for Hazardous Air Pollutants Registered and Unregistered Stack (Powered Exhaust) Source Assessment. W. E. Davis, Westinghouse Hanford Company, Richland, Washington. 


\section{Hanford Site Environmental Monitoring Plan}

\section{Section II.B. Near-Facility Environmental Monitoring}

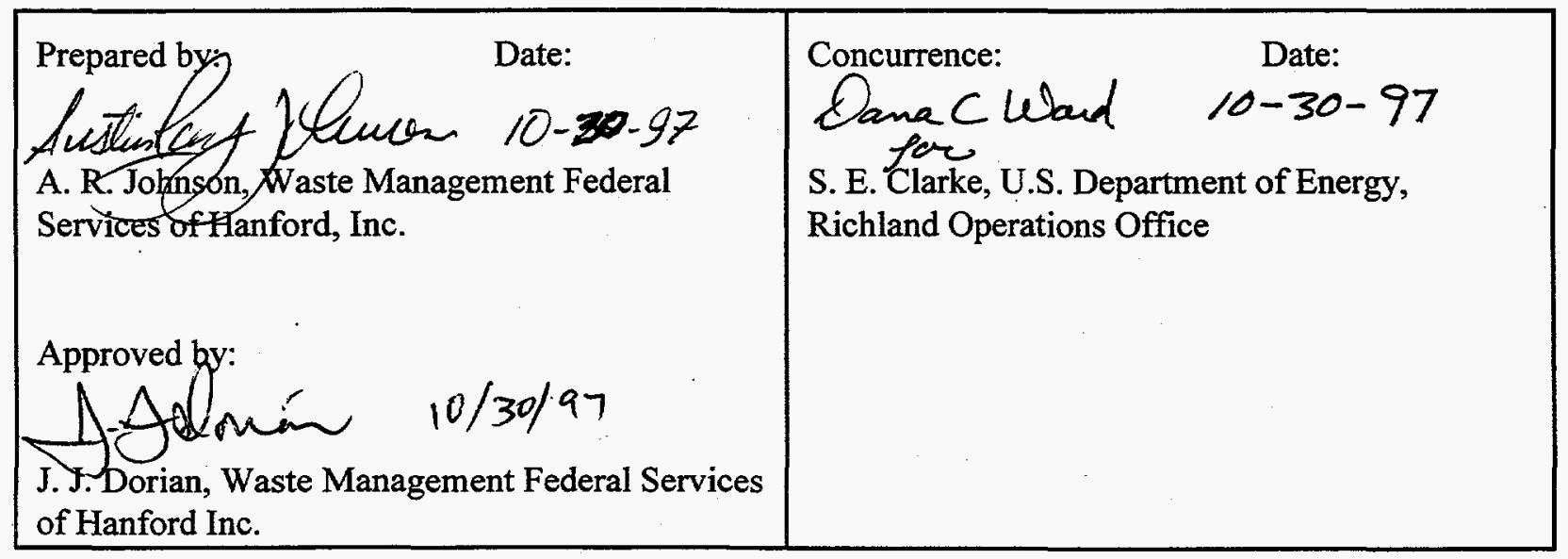




\section{Introduction}

Near-facility environmental monitoring is an important element of the Effluent and Environmental Monitoring Program managed by Waste Management Federal Services of Hanford, Inc. and is performed by Waste Management Federal Services, Inc., Northwest Operations in accordance with U.S. Department of Energy (DOE) Order 5400.1 and quality assurance criteria specified in HNF-EP-0538-3. Hanford Site facilities and operations with potential for significant environmental impact are sampled during preoperational environmental monitoring to establish an environmental baseline upon which to design the routine near-facility environmental monitoring to be performed.

\section{Preoperational Environmental Survey}

A preoperational environmental survey is required by Chapter IV, Paragraph 3 of DOE Order 5400.1:

"An environmental study shall be conducted prior to startup of a site, facility, or process which has the potential for significant adverse environmental impact. The preoperational study should begin not less than one year, and preferably two years before startup to evaluate seasonal changes. The study shall serve to: characterize existing physical, chemical, and biological conditions that could be affected; establish background levels of radioactive and chemical components; characterize pertinent environmental and ecologic parameters; and identify potential pathways for human exposure and environmental impact as a basis for determining the nature and extent of the subsequent routine operational and emergency effluent monitoring and environmental surveillance programs. Where time and circumstance do not allow for completion of preoperational monitoring prior to startup, it shall be conducted concurrent with work on the new site, facility, or process. The preoperational study shall be consistent with NEPA compliance activities. Where appropriate, activities and documentation conducted for NEPA compliance may substitute for compliance with this requirement."

General guidelines for conducting the preoperational environmental survey can be found in DOE/ EH-0173T and DOE/LLW-13Tg, Rev. 2. Specific references for conducting the preoperational environmental survey can also be found in HNF-PRO-453 and WMNW-CM-004.

\section{User Identification}

There are five primary users of a preoperational environmental survey:

1) the planning and construction organization (to demonstrate compliance with DOE Order 5400.1)

2) the facility operating organization (to show that containment systems for stored chemicals and wastes remain adequate in compliance with DOE Order 5400.1)

3) the program staff (to provide adequate data for determining the need to modify the existing nearfacility monitoring objectives and to determine effluent trends and environmental conditions) 
4) the Surface Environmental Surveillance Project (managed by Pacific Northwest National Laboratory) to adjust monitoring locations if needed

5) legal counsel to provide input to plaintiff requests and demonstrate regulatory compliance.

\section{Survey Design}

A preoperational environmental survey is designed to monitor the media specified in DOE/EH-0173T and DOE/LLW-13Tg, Rev. 2. To assist in designing this survey, existing documents (e.g., unplanned release reports, occurrence reports, operational and site environmental reports, historical photographs, environmental impact statements, and preliminary safety analysis reports) are reviewed.

Before initiating preoperational sampling of any new or modified facility or process, a sampling and analysis plan is prepared and issued. The sampling and analysis plan contains a project description, media to be sampled, analyses to be performed, and sampling design rationale.

Once preoperational monitoring is completed and analytical data are available, the results are included in a final preoperational environmental monitoring report (e.g., WHC-SD-W058-RPT-001, WHC-SD-WM-TI-778).

\section{Routine Near-Facility Environmental Monitoring}

Facility-specific environmental monitoring is provided for the protection of the environment adjacent to nuclear facilities and waste-treatment, -storage, and -disposal sites in compliance with applicable federal, state, and local environmental regulations and requirements.

The objectives of this monitoring are to evaluate the following:

- compliance with federal, state, and local environmental radiation protection requirements and guides

- performance of radioactive waste-confinement systems

- concentration trends of radioactive materials in the environment at and adjacent to nuclear facilities and waste-disposal sites.

Specifically, near-facility environmental monitoring entails the following functions:

- monitoring all inactive, existing, and new low-level waste-disposal sites to assess both radiological and nonradiological hazards (DOE Order 5820.2A)

- determining the effectiveness of treatments and controls used to reduce effluents and emissions (DOE/EH-0173T) 
- detecting and quantifying unplanned releases (DOE/EH-0173T, 40 CFR 302, WAC 173-303-145, DOE Orders 5000.3A and 5484.1)

- monitoring fugitive emissions (i.e., diffuse sources) from contaminated areas for compliance with national emission standards for hazardous air pollutants (40 CFR 61, DOE/EH-0173T), toxic air emissions (40 CFR 265, Subparts AA and B13), state operating permits (40 CFR 70), and source registration (WAC 246-247)

- monitoring all surplus facilities before decontaminating or decommissioning (DOE Order 5820.2A)

- monitoring new and existing sites, processes, and facilities to determine potential environmental impacts and releases of contaminants (DOE Order 5484.1, DOE/EH-0173T)

- monitoring and assessing environmental radioactive contamination and potential exposure to employees and the public (DOE Orders 5400.1 and 5400.5).

The primary justifications for near-facility environmental monitoring include the following:

- provide a level of assurance that the effluent and contamination controls for the various facilities and waste sites are effective

- monitor a diversity of operations, activities, and programs managed by several different organizations (accordingly, direction and integration are needed to ensure consistency, technical quality, and cost effectiveness)

- provide data to ensure safe site access.

Near-facility environmental monitoring staff are responsible for planning, directing, and executing the effective, technically sound monitoring of all media (except groundwater) and for ensuring that the regulations and requirements are satisfied. This responsibility includes establishing the basis and scope, developing the sample and survey schedules, and ensuring that the schedules and procedures are followed by the performing organizations. The staff serve as the primary contact within and outside of Hanford Site contractors in technical matters pertaining to near-facility environmental monitoring and represent Hanford Site contractors at meetings with environmental regulators regarding this type of work.

Data obtained as a result of near-facility environmental monitoring are used to identify areas of noncompliance with regard to loss of contamination control. Radiological problem reports and compliance assessment reports are the formal mechanisms for documenting instances of noncompliance. Formal tracking of noncompliance is also performed. Near-facility environmental monitoring staff are integral to the process of developing compliance schedules for the noncompliant organization, which are then closely tracked to determine their effectiveness. These activities solidify the oversight function of near-facility environmental monitoring and perform the critical function of formally identifying areas of concern regarding unacceptable environmental conditions.

A list of federal, state, and Hanford Site documents regulating activities is given in Table II.B-1. 
Table II.B-1. Governing Documents

Document Number

DOE Order 5400.1

Chapter III, Environmental

Protection Program Plans

Chapter IV, Environmental

Monitoring Requirements

DOE Order 5400.5

Chapter I, General, Paragraph 8, Environmental Monitoring and

Surveillance

DOE Order 5820.2A

DOE Order 5484.1

DOE Order 5000.3A

DOE/LLW-13Tg, Rev. 2

DOE/EH-0173T

40 CFR 61

40 CFR 70

40 CFR 264

40 CFR 265

40 CFR 302

WAC 173-303-145

WAC 246-247

DOE/RL-91-50 (latest revision)

HNF-PRO-453

HNF-PRO-454

HNF-PRO-455

WMNW-CM-004

HNF-EP-0538-3
Title

General Environmental Protection Program

Radiation Protection of the Public and the Environment

Radioactive Waste Management

Environmental Protection, Safety, and Health Protection Information Reporting Requirements

Occurrence Reporting and Processing of Operational Information

Low Level Waste Management Handbook Series, Environmental Monitoring for Low Level Waste Disposal Sites

Environmental Regulatory Guide for Radiological Effluent Monitoring and Environmental Surveillance

National Emission Standards for Hazardous Air Pollutants

State Operating Permit Programs

Final Status Standards for Owners and Operators of Hazardous Waste Treatment, Storage, and Disposal Facilities

Interim Status Standards for Owners and Operators of Hazardous Waste Treatment, Storage, and Disposal Facilities

Designation, Reportable Quantities, and Notification

Dangerous Waste Regulations (Spills and Discharges into the Environment)

Radiation Protection - Air Emissions

Environmental Monitoring Plan, United States Department of Energy, Richland Operations Office

Environmental Notification and Reporting

Inactive Waste Sites

Solid Waste Management

Environmental Monitoring

Near-Facility Environmental Monitoring Program Quality Assurance Project Plan 


\section{User Identification}

There are five primary users of a preoperational environmental survey:

1) the planning and construction organization (to demonstrate compliance with DOE Order 5400.1)

2) the facility operating organization (to show that containment systems for stored chemicals and wastes remain adequate in compliance with DOE Order 5400.1)

3) the program staff (to provide adequate data for determining the need to modify the existing nearfacility monitoring objectives and to determine effluent trends and environmental conditions)

4) the Surface Environmental Surveillance Project (managed by Pacific Northwest National Laboratory) to adjust monitoring locations if needed

5) legal counsel to provide input to plaintiff requests and demonstrate regulatory compliance.

\section{Review}

The scope of near-facility environmental monitoring is reviewed by management and staff at least annually to ensure that the work complies with regulations, that appropriate effluents are being monitored, and that the monitoring locations are positioned to best determine and quantify potential releases.

\section{Design}

\section{Sampling Locations, Frequency, Media Sampled, and Parameters Monitored}

Media near active/inactive facilities to be sampled include ambient air particulates, soil, surface water, sediment, and biota. Parameters routinely monitored include, as appropriate, radionuclide concentrations, radiation exposure levels, radiation dose, hazardous constituent concentrations, $\mathrm{pH}$, and water temperatures. Sample types, collection and measurement frequencies, and analytes and parameters monitored are given in Table II.B-2.

\section{Monitoring Locations}

Information regarding specific sampling locations can be found in WMNW-CM-004. The criteria for establishing monitoring locations for each of the media in Table II.B-2 are as follows:

- soil - downwind and within a few meters of a source. Unless documented site-specific evidence exists to justify otherwise, the sample(s) will be collected in a location free from unusual localized effects or other conditions (i.e., near a large building, vehicular traffic, trees) that could result in artificially high or low concentrations. 
Table II.B-2. Near-Field Sampling Media, Frequency, Analytes, and Parameters

\begin{tabular}{llll}
\multicolumn{1}{c}{ Sample Types } & $\begin{array}{c}\text { Collection or } \\
\text { Measurement } \\
\text { Frequency }\end{array}$ & & \multicolumn{1}{c}{ Analytes/Parameters Monitored } \\
\cline { 1 - 2 } Air & $\begin{array}{c}\text { Biweekly } \\
\text { Semiannual }\end{array}$ & & $\begin{array}{l}\text { Total alpha and beta } \\
\text { Strontium, plutonium, uranium, gamma }\end{array}$ \\
Soil & Annual & & $\begin{array}{l}\text { Strontium, plutonium, uranium, gamma } \\
\text { Vegetation }\end{array}$ \\
Animals & Annual & & Strontium, plutonium, uranium, gamma \\
Thermoluminescent dosimeter & Annual & & Strontium, plutonium, uranium, gamma \\
Survey points & Quarterly & & Radiation dose \\
Surface water & Annual & & Radiation dose \\
River seepage & Weekly & & pH \\
Sediment & Monthly & & Total alpha, beta, strontium, gamma \\
Aquatic vegetation & Annual & Strontium, gamma, tritium \\
Annual & Strontium, plutonium, uranium, gamma
\end{tabular}

- vegetation - on or near sites and/or facilities with the potential for biological intrusion

- animals - on or near sites and/or facilities with the potential for biological intrusion. Animals are sampled opportunistically.

- surface water, sediment, and aquatic vegetation - at ponds or ditches used for disposal of, or potentially impacted by, liquid effluents from operating facilities

- background dose rate - at or near facilities that may cause elevated dose rates, including active/ inactive sites, access areas, waste-handling facilities, effluent-discharge points, and other suspected pathways for radiation exposure

- radiation surveys - at inactive waste sites; outdoor radiological control areas; tank farm perimeters and associated diversion boxes, lift stations, and vent stations; perimeters of active or uncovered waste sites (e.g., retention basins, ponds, process trenches, ditches); and road and rail surfaces.

\section{Sampling Frequency}

A routine near-facility environmental monitoring schedule is developed, reviewed, and approved by Waste Management Federal Services, Inc., Northwest Operations, Waste Management Federal Services of Hanford, Inc., Fluor Daniel Hanford, Inc., and Bechtel Hanford, Inc. The near-facility environmental monitoring staff reviews the radiological survey reports and files a copy for historical purposes and 
reference. Radiological conditions are tracked and trends are noted. The survey frequencies for particular sites are based on site history, radiological conditions, and general maintenance. All sites are surveyed at least once each year. Special surveys may be conducted at irregular frequencies if conditions warrant (e.g., growth of deep-rooted vegetation is noted at a waste site). Radiological surveys are conducted to detect surface contamination and to document changes in vegetation growth, biological intrusion, erosion, and general site-maintenance conditions. Survey data are compared with standards identified in HNF-PRO-453, HNF-PRO-454, and HNF-PRO-455, as well as previous surveys to recognize possible trends, to assess environmental impacts, and to help determine where corrective actions are needed.

\section{Sampling Methods}

Sampling methods are reviewed to determine equipment efficiency and to comply with current federal (U.S. Environmental Protection Agency) and industry (American National Standards Institute, American Society for Testing and Materials) standards. The following sampling methods are routinely used for near-facility environmental monitoring:

- ambient air - air-sampling stations collect samples at a height of $2 \mathrm{~m}$ above ground level and use a vacuum pump to provide air flow of $2 \mathrm{ft}^{3} / \mathrm{min}$. A timer and flow-rate meter are used to determine time and flow of the sampler. Samples are collected biweekly to prevent dust loading on the sample filter.

- soil - soil-sampling equipment may be one of three types: 1) a garden spade, 2) a core sampler (split spoon) for special soil sampling, or 3) a plug ("cookie cutter") sampler for routine samples. All equipment is easily decontaminated or is disposable. Samples are placed in a sealable plastic bag or other suitable container and, if necessary, into an appropriate container for shipment.

- vegetation - vegetation-sampling equipment consists of pruning shears, loppers, saws, core drill, or machete. Samples are cut to length, placed in a plastic bag, and, if necessary, into an appropriate container for shipment.

- animals - animal samples are usually collected by pest control staff. The animals are checked for radioactive contamination by radiation control staff; those animals found to be contaminated may be kept for analysis. The samples are put in a plastic bag and, if necessary, into an appropriate container for shipment.

- surface water - surface water-collection equipment consists of a clean cup $(\sim 1 \mathrm{~L})$ attached to the end of a sampling pole. The sample is taken at the designated sampling location by dipping the sampling cup into the surface water (being careful not to disturb the sediments). The sample is then poured into a larger sample container, and the process repeated until the sample container is full. One additional full cup of sample is then taken from the surface water, and a field $\mathrm{pH}$ reading is taken. This sample is then returned to the surface water.

- sediment - sediment samples are collected using two methods:

- a soil core sampler equipped with a sample liner. The core sampler is forced into the sediment to a depth of $30 \mathrm{~cm}$. The liner is withdrawn from the sampler, and the retained sediment is placed into a watertight plastic jar, sealed, and labeled appropriately for delivery to the designated laboratory for analyses. 
- a flat-bladed shovel and "cookie cutter"/spatula-type sampler. The sample is collected by skimming an approximate $2.54-\mathrm{cm}$-deep portion of sediment into the shovel and removing it carefully from the water. The cookie cutter is forced into the sediment. Excess sediment is removed by scraping it away with the spatula. The spatula is then carefully placed under the cookie cutter, trapping the sample. The sample is placed in a watertight plastic jar, sealed, and labeled appropriately for delivery to the designated laboratory for analyses.

- aquatic vegetation - aquatic vegetation samples are collected using various tools (e.g., shears, pruners, loppers). Vegetation is collected either directly from the water source or bank in 500-g samples and placed in a plastic bag. The sample is double bagged and labeled appropriately for delivery to the designated laboratory for analyses.

- background dose rates - background dose rates are taken by two methods: thermoluminescent dosimeters (TLDs) and micro-rem meters. The TLDs consist of four lithium fluoride (TLD-700) and one calcium fluoride dysprosium (TLD-200) chips in a plastic card supplied by Pacific Northwest National Laboratory. Three TLDs are placed at each sampling location on a post at $1 \mathrm{~m}$ from the surface. Micro-rem meters are used to measure relative background dose rates.

- radiation surveys - radiation surveys include road/railroad surfaces, cribs, stabilized burial grounds, covered ponds and ditches, tank farm perimeters, active burial ground perimeters, unplanned release sites, and other radiation areas.

Road surveys are performed with a mobile surface contamination monitor or a vehicle equipped with sodium iodide detectors or plastic scintillators. Railroad surveys are conducted with a vehicle equipped with sodium iodide detectors and "high railers," which allow the vehicle to travel both on the roads or railroads. The detector height is adjustable in all cases, and the average survey height is

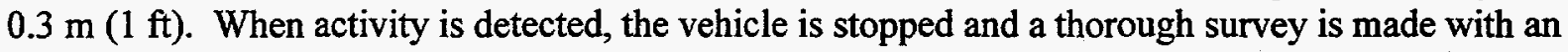
Eberline Model BNW-1 portable survey instrument equipped with a P-11 probe to identify the extent of the contamination.

Surveys at waste sites and other radiation areas may be conducted with vehicles equipped with radiation detection instruments or with hand-held field instruments. Wherever possible, smear surveys are made on the surface of exposed equipment within a radiation area. Vegetation, animal burrows, and animal feces are also monitored to detect biological transport. Detailed survey practices and procedures are described in WMNW-CM-004, HNF-CM-1-6, HSRCM-1, and HNF-IP-0718.

\section{Parameters Monitored}

The parameters to be monitored for each medium vary and may include the following:

- ambient air - isotopic or total gamma, strontium, plutonium, uranium, and tritium at selected locations

- soil - isotopic or total gamma, strontium, plutonium, and uranium

- vegetation - isotopic or total gamma, strontium, plutonium, and uranium

- animals - isotopic or total gamma, strontium, plutonium, and uranium 
- surface water, sediment, and aquatic vegetation - isotopic or total gamma, strontium, tritium, plutonium, uranium, nitrates, and $\mathrm{pH}$

- background dose rate - measured in the area where samples are taken to identify any increasing or decreasing trends in background radiation that may affect the environment, the workers, or the public

- radiation surveys - performed to measure the surface and background radiation in the area in which the measurement is taken.

Samples are typically analyzed for the constituents listed in facility effluent monitoring plans for the facility of concern (see Section II.A). Best professional judgment is used to locate initial sampling sites to monitor the near-facility environment.

\section{References}

40 CFR 61, Code of Federal Regulations, Title 40, Part 61. National Emission Standards for Hazardous Air Pollutants.

40 CFR 70, Code of Federal Regulations, Title 40, Part 70. State Operating Permit Programs.

40 CFR 264, Code of Federal Regulations, Title 40, Part 264. Final Status Standards for Owners and Operators of Hazardous Waste Treatment, Storage, and Disposal Facilities.

40 CFR 265, Code of Federal Regulations, Title 40, Part 265. Interim Status Standards for Owners and Operators of Hazardous Waste Treatment, Storage, and Disposal Facilities.

40 CFR 302, Code of Federal Regulations, Title 40, Part 302. Designation, Reportable Quantities, and Notification.

DOE/EH-0173T. 1991. Environmental Regulatory Guide for Radiological Effluent Monitoring and Environmental Surveillance. Assistant Secretary for Environment, Safety and Health, U.S. Department of Energy, Washington, D.C.

DOE/LLW-13Tg, Rev. 2. 1990. Low Level Waste Management Handbook Series, Environmental Monitoring for Low Level Waste Disposal Sites. U.S. Department of Energy, Washington, D.C.

DOE Order 5000.3A. “Occurrence Reporting and Processing of Operational Information."

DOE Order 5400.1. "General Environmental Protection Program."

DOE Order 5400.5. "Radiation Protection of the Public and the Environment."

DOE Order 5484.1. "Environmental Protection, Safety, and Health Protection Information Reporting Requirements."

DOE Order 5820.2A. "Radioactive Waste Management." 
DOE/RL-91-50, Rev. 1. 1994. Environmental Monitoring Plan, United States Department of Energy, Richland Operations Office. U.S. Department of Energy, Richland Operations Office, Richland, Washington.

HSRCM-1. 1977. Hanford Site Radiological Control Manual. Fluor Daniel Hanford, Inc., Richland, Washington.

HNF-IP-0718. 1977. Health Physics Procedures. Fluor Daniel Hanford, Inc., Richland, Washington.

HNF-CM-1-6. 1977. HNF Radiation Control Manual. Fluor Daniel Hanford, Inc., Richland, Washington.

HNF-EP-0538-3. 1997. Near-Facility Environmental Monitoring Program Quality Assurance Project Plon. S. M. McKinney, Waste Management Federal Services of Hanford, Inc., Richland, Washington.

HNF-PRO-453. 1997. Environmental Notification and Reporting. Fluor Daniel Hanford, Inc., Richland, Washington.

HNF-PRO-454. 1997. Inactive Waste Sites. Fluor Daniel Hanford, Inc., Richland, Washington.

HNF-PRO-455. 1997. Solid Waste Management. Fluor Daniel Hanford, Inc., Richland, Washington.

WAC 173-303-145, Washington Administrative Code. Dangerous Waste Regulations (Spills and Discharges into the Environment). Olympia, Washington.

WAC 246-247, Washington Administrative Code. Radiation Protection - Air Emissions. Olympia, Washington.

WHC-SD-W058-RPT-001. 1995. Preoperational Environmental Survey Report: 200 Areas Cross-Site Transfer Line Replacement (W-058). A. R. Johnson, R. M. Mitchell, and C. A. Rowley, Westinghouse Hanford Company, Richland, Washington.

WHC-SD-WM-TI-778. 1996. Preoperational/Operational Environmental Survey Report: Solid Waste Operations Complex. R. M. Mitchell and A. R. Johnson, Westinghouse Hanford Company, Richland, Washington.

WMNW-CM-004. 1997. Environmental Monitoring. Waste Management Federal Services, Inc., Northwest Operations, Richland, Washington. 


\title{
Hanford Site Environmental Monitoring Plan
}

\author{
Section III.A. Surface Environmental Surveillance
}

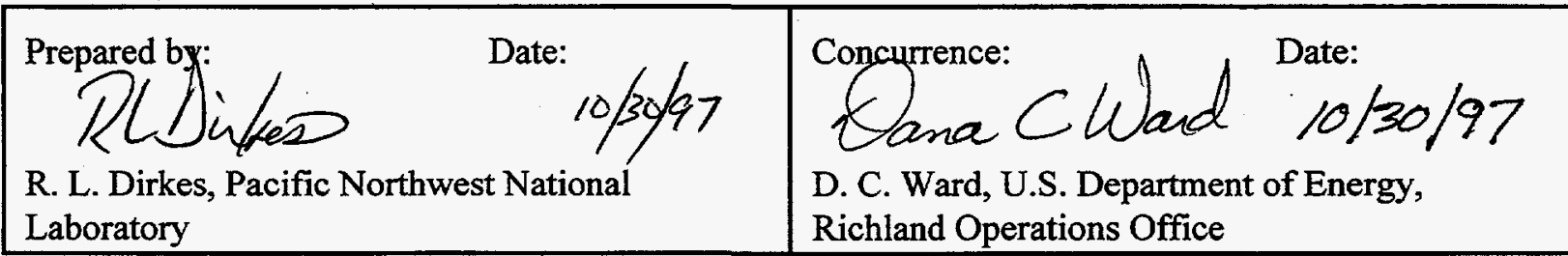




\section{Introduction}

This section describes the Hanford Site plan for surface environmental surveillance. Environmental surveillance includes all components of the surface environment. The purpose of this section is to describe how the surveillance requirements of U.S. Department of Energy (DOE) Orders 5400.1 and 5400.5 and the guidance of DOE/EH-0173T are to be met for the Hanford Site.

The Surface Environmental Surveillance Project, conducted by Pacific Northwest National Laboratory (PNNL) for DOE, is a multimedia environmental monitoring effort to measure the concentration of radionuclides and chemicals in environmental media and assess the integrated effects of these materials on the environment and the public. The project collects samples of air, surface water, sediments, soil and natural vegetation (approximately every $5 \mathrm{yr}$ ), agricultural products, fish, and wildlife. Analytical capabilities include the measurement of radionuclides at very low environmental concentrations and nonradiological chemicals, including metals, anions, thioureas, volatile organic compounds, semivolatile organic compounds, pesticides, and polychlorinated biphenyls. In addition, the project includes the capability to measure ambient external radiation.

Activities inherent in the operation of the Surface Environmental Surveillance Project include design and implementation, sample collection, sample analysis, database management, data review and evaluation, exposure assessment, and reporting. Other elements of the project include project management, quality assurance/control, training, and records management.

The project focuses on routine releases from DOE facilities on the Hanford Site; however, the project is also responsive to unplanned releases and releases from non-DOE operations on and near the site. Surveillance results are provided annually through the Hanford Site environmental report (e.g., PNNL-11472). In addition, unusual results or trends are reported to DOE and the appropriate facility managers when they occur. Whereas effluent and near-facility environmental monitoring are conducted by the facility operating contractor, environmental surveillance is conducted under an independent program and reports directly to the DOE-Richland Operations Office (RL) Environmental Assurance, Permits and Policy Division.

Although the scope of the Surface Environmental Surveillance Project has expanded during recent years to include hazardous chemical surveillance, this plan focuses on radiological surveillance in response to DOE requirements. This plan is written to comply with all should* statements in DOE/ EH-0173T unless noted otherwise in the Exceptions discussions. Should statements are described in DOE/EH-0173T as flexible guidance; this guidance has been considered in the development of this plan and incorporated where determined appropriate. However, lack of incorporation of such statements has not been noted in the Exceptions discussions.

This section (III.A) of the plan is related to other sections in several respects. The sampling design described is based on radiological and chemical pathway analyses that utilize the source data obtained under the effluent-monitoring program described in Section II.A and the near-facility environmental monitoring program described in Section II.B. The pathway analysis and dose assessment conducted for this plan and the dose assessments reported in the annual Hanford Site environmental report (e.g., PNNL-11472) use the dispersion data provided by the Meteorological and Climatological Services Project described in Section III.C. The pathway analyses and dose assessment conducted for this section include the contribution to dose from the groundwater pathway discussed in Section III.B. 
The environmental pathways carrying contaminants to humans and the significance of the media and contaminants to total dose are strongly influenced by the environmental setting. The Hanford Site's environmental setting is summarized in PNNL-6415 Rev. 9 and will not be described here.

\section{Requirements and Objectives}

The general requirements and objectives for environmental surveillance are contained in DOE Orders 5400.1 and 5400.5. The broad objectives (DOE Order 5400.1) are to demonstrate compliance with legal and regulatory requirements, to confirm adherence to DOE environmental protection policies, and to support environmental management decisions. These requirements are embodied in the surveillance objectives stated in the DOE Orders and DOE/EH-0173T and include the following:

- determine compliance with applicable environmental quality standards and public exposure limits and applicable laws and regulations; the requirements of DOE Orders 5400.1 and 5400.5; and the environmental commitments made in environmental impact statements, environmental assessments, safety analysis reports, or other official DOE documents: Additional objectives that derive from the DOE Orders and this primary objective include the following:

- conduct preoperational assessments

- assess radiological doses to the public and aquatic biota from site operations

- assess doses from other local sources

- report alarm levels and potential doses exceeding reporting limits (DOE Order 5400.5, Chapter II, Section 7)

- prepare an annual site environmental report

- maintain an environmental monitoring plan

- determine background levels and site contributions of contaminants in the environment

- determine long-term accumulation of site-related contaminants in the environment and predict trends; characterize and define trends in the physical, chemical, and biological condition of environmental media

- determine effectiveness of treatment and controls in reducing effluents and emissions

- determine validity and effectiveness of models to predict the concentrations of pollutants in the environment

- detect and quantify unplanned releases

- identify and quantify new or existing environmental quality problems. 
DOE/EH-0173T indicates that subsidiary objectives for surveillance should be considered. Subsidiary objectives applicable to the site include the following:

- obtain data and maintain the capability to assess the consequence of accidents

- provide public assurance; address issues of concern to the public, business, and regulators

- enhance public understanding of site environmental impacts, primarily through public involvement and by providing public information

- provide environmental data and assessments to assist DOE-RL in environmental management of the site.

The DOE Orders require that the content of surveillance programs be determined on a site-specific basis by DOE-RL. The surveillance programs must reflect facility characteristics; applicable regulations; hazard potential; quantities and concentrations of materials released; extent and use of affected air, land, and water; and specific local public interest and concern.

\section{Surface Environmental Surveillance Design}

DOE Orders 5400.1 and 5400.5 require that the content of surveillance programs be determined on a site-specific basis by DOE-RL. The surveillance programs must reflect facility characteristics; applicable regulations; hazard potential; quantities and concentrations of materials released; extent and use of affected air, land, and water; and specific local public interest and concern. Environmental surveillance is designed to meet the listed objectives while considering the environmental characteristics of the site and potential and actual releases from site operations. Surveillance activities focus on determining environmental impacts and compliance with public health and environmental standards or protection guides rather than on providing detailed radiological and chemical characterization. Experience gained from environmental surveillance activities and studies conducted at the Hanford Site for more than $50 \mathrm{yr}$ provide valuable technical background for planning the surveillance design.

This subsection discusses the rationale and criteria, surveillance design, and annual surveillance design-review process.

\section{Rationale and Design Criteria}

The rationale and criteria for environmental surveillance are based on the following:

- DOE Orders 5400.1 and 5400.5

- DOE/EH-0173T

- surveillance objectives

- results of the radiological and chemical pathway analyses

- other site commitments. 
The minimum objective criteria for determining the content of surveillance projects are contained in Tables 5-1 and 5-2 of DOE/EH-0173T and Table 4 of Section 7 of EPA-520/1-80-012.

Based on current doses and the above-referenced objective criteria alone, periodic surveillance measurements are required a minimum of every $5 \mathrm{yr}$ to confirm that the doses are below the objective criteria.

However, conducting only confirmatory surveillance measurements every $5 \mathrm{yr}$ at the site and in the surrounding region would not fully meet the primary surveillance objectives (see Requirements and Objectives) or satisfy the subsidiary objectives. The rationale and criteria for additional sampling in each medium will be discussed in the subsections that follow. First, there are some general considerations that will be factors in decisions about the content of the surveillance design.

The application of objective criteria from DOE/EH-0173T to the radiological pathway analyses results addresses only surveillance for routine releases and does not consider the inventory potentially available for release. The potential inventory of activity disposed to the ground is very large (5.6 million Ci). In addition, it is estimated that there are 209 million $\mathrm{Ci}$ in waste-storage tanks, 174 million $\mathrm{Ci}$ (cesium and strontium) in capsule storage, 63 million $\mathrm{Ci}$ in irradiated fuel, 651 thousand $\mathrm{Ci}$ in stored solids, and 16 million $\mathrm{Ci}$ in isotopic heat sources. Likewise, the inventory of hazardous chemicals onsite, while not well quantified or documented, is believed to be of considerable magnitude.

The need for routine surveillance independent of the operating contractor is reinforced by the recognition that expedited cleanup actions under the Hanford Federal Facility Agreement and Consent Order (also known as the Tri-Party Agreement; Ecology et al. 1989) have begun and that cleanup actions will increase and continue over the next few decades. This activity, in some cases applying cleanup technologies that have never been used before, increases the potential for the release to and migration within the environment of materials that are currently well contained. The design for routine surveillance must address the need to establish baselines to measure the integrated effects of various cleanup actions across the site and to monitor the trends that may result from these operations.

Design rationale and criteria that apply to most media are summarized below.

\section{Media Selection}

Highest priority is to be given to sampling media that are directly ingested or inhaled by the public. Additional media are selected based on their sensitivity as indicators of loss of control, for their ability to predict accumulations and trends, or as indicators of environmental quality.

\section{Sampling Locations}

Background sampling locations are to be established for all media-contaminant combinations routinely sampled or that would likely have to be sampled to assess the effects of unusual or accidental releases. Sampling locations are selected near potential sources to maximize the probability of detecting losses of containment, to establish baselines, and to assess the effects of releases. Sampling stations are positioned at the site perimeter (near or just inside the site boundary) to estimate conditions at the nearest points at which members of the public reside or could reside. Exposures at these locations are typically the maximum that any member of the public could receive. Finally, sampling is conducted in the community locations where the highest potential chronic impacts are expected to occur, both to provide measurements where the most people are potentially exposed and to provide assurance to the communities that levels are well below standards established to protect public health. 


\section{Sampling and Analysis Frequencies}

Sampling frequency selection is based on the rate at which significant changes are expected and the need to obtain time-representative samples. In general, sampling near onsite effluents will be the most frequent, sampling at the perimeter will be less frequent, and sampling at distant offsite locations will be the least frequent. The exposure or sample integration period may be up to $1 \mathrm{yr}$ but no more than twice the radionuclide half-life. The minimum exposure period must be constrained to the operating limits (flow, breakthrough, etc.) of the sampling medium necessary to obtain a sample representative of the exposure period. Periodic samples are composited for longer-lived radionuclides to increase time representativeness and to lower detection limits.

\section{Detection and Precision}

The general surveillance criterion is to use the lowest level of detection practical, utilizing standard analytical procedures and considering practical sampling strategy tradeoffs (e.g., time and location compositing versus discrete samples and practical sampling trains). Where technically feasible and practical, the minimum objective for a given medium-radionuclide combination is to detect concentrations at or below the concentration that would result in a dose to humans of $1 \mathrm{mrem} / \mathrm{yr}$ effective dose equivalent (EDE) if that concentration were sustained for a year. This dose estimate assumes that the radionuclide is being transported to subsequent compartments of the pathway and that the individual is exposed to all subsequent compartments. For example, the limit for air assumes not only inhalation but also exposure from deposition, vegetation uptake, consumption, etc. One millirem is selected as the minimum criterion because it is $10 \%$ of the level at which potential doses to the public must be reported to DOE-Headquarters (HQ), as well as being 10\% of the dose limit (Code of Federal Regulations, Title 40, Part 61 [40 CFR 61]) for the air pathway, thereby providing a high level of assurance that these requirements will be met.

The current detection criteria (by radionuclide and medium) are contained in the subsection entitled Laboratory Procedures. Except for ${ }^{14} \mathrm{C}$ in air, these detection limits are well below the $1-\mathrm{mrem}$ level and are driven by the goal of obtaining the lowest practical level of detection using standard methods. Analytical precision criteria are contained in the subsection entitled Quality Assurance and Quality Control.

The rationale, design criteria; and plan for surveillance measurements to meet the primary and subsidiary objectives are described in the media-specific subsections.

\section{Dose Assessment}

Pathway and dose assessments are conducted as follows:

- annually to assess compliance with DOE Order 5400.5 public limit and 40 CFR 61 criteria

- annually to determine the minimum needs for environmental surveillance as defined in DOE/EH-0173T

- at least every $5 \mathrm{yr}$ to assess compliance with DOE Order 5400.5 interim aquatic biota limit or when exposure conditions have changed significantly, at the discretion of the cognizant PNNL manager.

The need for updates to dose assessment codes or input data is controlled through procedures established by the Hanford Environmental Dose Overview Panel (discussed in the subsection entitled 
Dosimetry Coordination). The Panel establishes a site policy for reviewing and updating population and pathway data, a frequency for the review of input data, and guidelines for when new data must be incorporated into dose calculations.

\section{Surveillance Design}

The Hanford Site Surface Environmental Surveillance Project historically has focused on radionuclides in various media and nonradiological water quality parameters. In recent years, surveillance for nonradiological constituents, including hazardous chemicals, has been expanded significantly. A detailed chemical pathway and exposure analysis for the Hanford Site was completed in 1994 (PNNL-10714). The analysis helped guide the selection of chemical surveillance media, sampling locations, and chemical constituents.

Each year, a radiological pathway analysis and exposure assessment is performed. The pathway analysis is based on source-term data and on the comprehensive pathway and dose assessment methodology included in the Generation II (GENII) computer code (PNL-6584) used for estimating radiation doses to the public from Hanford Site operations. The CRITR computer code (PNL-8150) was used to calculate doses to animals, and manual calculations were used to compute the doses not addressed in the computer codes. The results of the pathway analysis and exposure assessment serve as a basis for future years' surveillance program design.

Exposure is defined as the interaction of an organism with a physical or chemical agent of interest. Thus, exposure can be quantified as the amount of chemical or physical agent available for absorption at the organism's exchange boundaries (i.e., dermal contact, lungs, gut, etc.). An exposure pathway is identified based on 1) examination of the types, location, and sources (contaminated soil, raw effluent, etc.) of contaminants; 2) principal release mechanisms; 3) probable environmental fate and transport (including persistence, partitioning, and intermediate transfer) of contaminants of interest; and, most important, 4) location and activities of the potentially exposed populations. Mechanisms that influence the fate and transport of a chemical through the environment and influence the amount of exposure a person might receive at various receptor locations are listed below.

Once a radionuclide or chemical is released into the environment it may be:

- transported (e.g., migrate downstream in solution or on suspended sediment, travel through the atmosphere, or be carried offsite in contaminated wildlife)

- physically or chemically transformed (e.g., deposition, precipitation, volatilization, photolysis, oxidation, reduction, hydrolysis, or radionuclide decay)

- biologically transformed (e.g., biodegradation)

- accumulated in the receiving media (e.g., sorbed strongly in the soil column, stored in organism tissues).

The primary pathways for movement of radioactive materials and chemicals from the site to the public are the atmosphere and surface water. Figures III.A-1 and III.A-2 illustrate these potential routes and exposure pathways to humans and biota, respectively. 


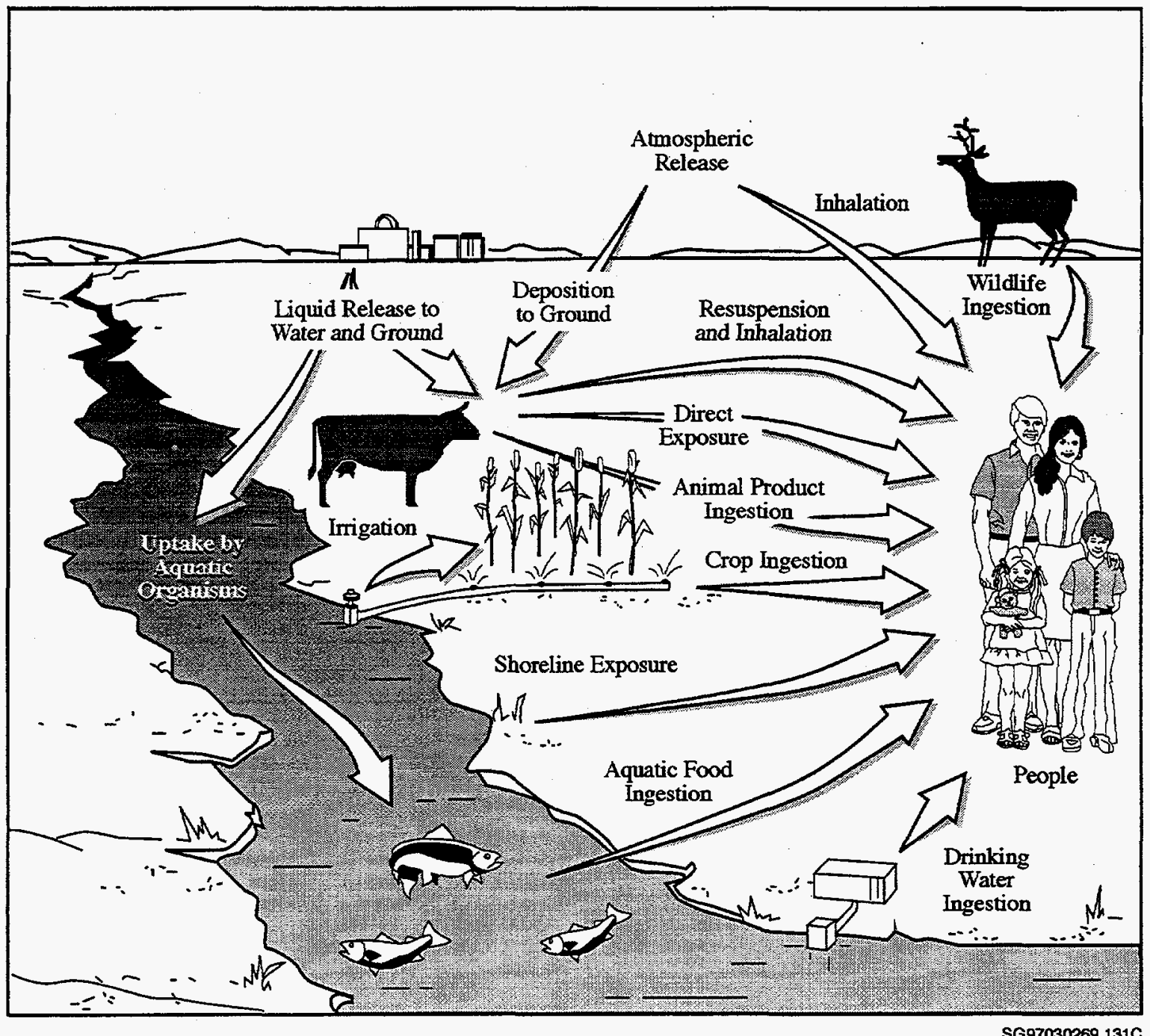

Figure III.A-1. Primary Exposure Pathways to Man

The significance of each pathway is determined from measurements and calculations that estimate the amount of radioactive material or chemical transported along each pathway and by comparing the concentrations or potential doses to environmental and public health-protection standards or guides. Pathways are also evaluated based on prior studies and observations of radionuclide and chemical movement through the environment and food chains. Calculations based on effluent data show the expected concentrations off the Hanford Site to be low for all Hanford-produced radionuclides and chemicals and to be frequently below the level that can be detected by monitoring technology. To ensure that radiological and chemical analyses of samples are sufficiently sensitive, minimum detectable concentrations of key radionuclides and chemicals have been established at levels well below applicable health standards.

Environmental and food-chain pathways are monitored near facilities releasing effluents and at potential offsite receptor locations. The surveillance design uses a stratified sampling approach to monitor these pathways. Samples are collected, and radionuclide and chemical concentrations are measured in three general surveillance zones that extend from onsite operational areas to the offsite environs. 


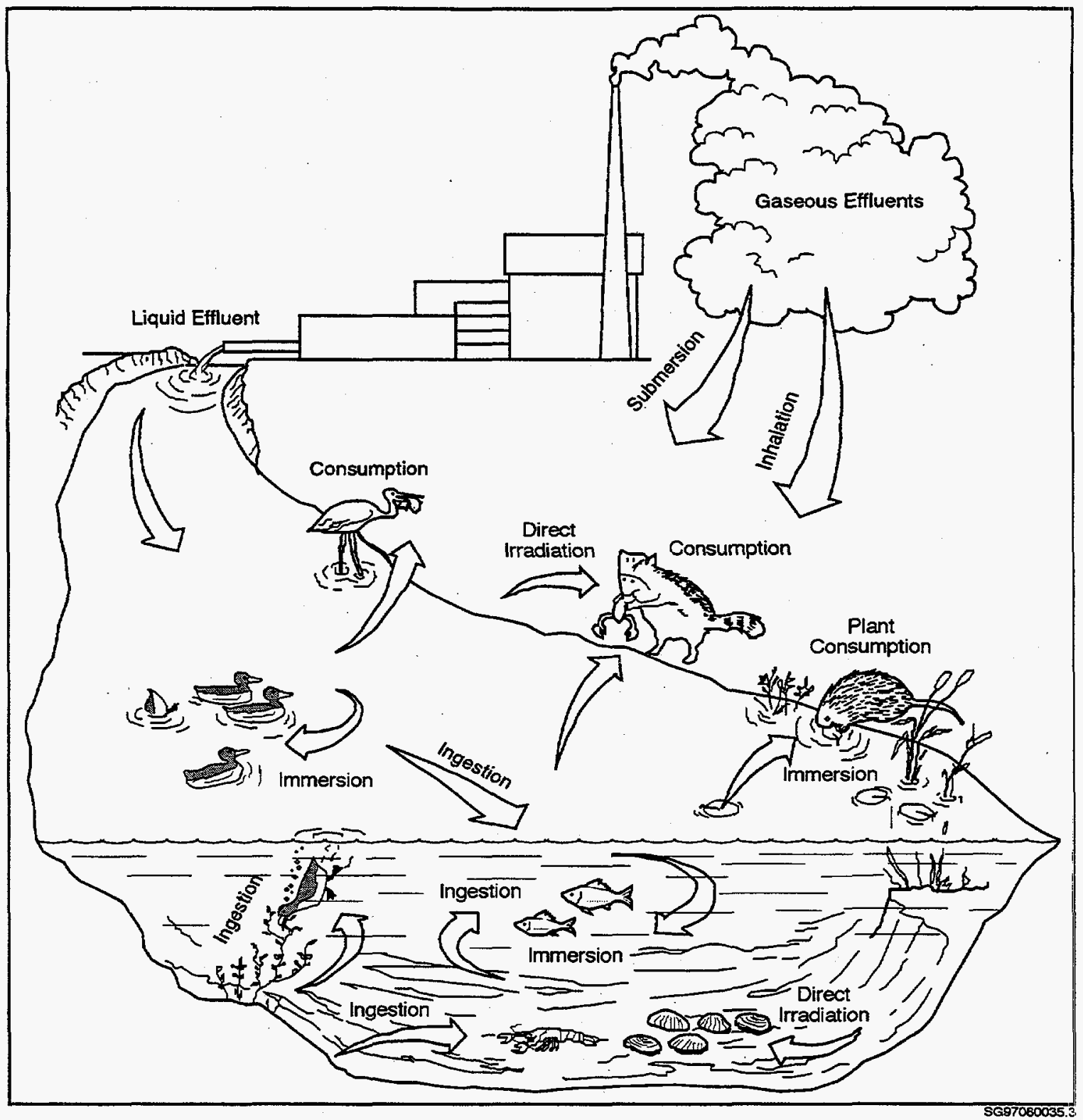

Figure III.A-2. Radiation and Chemical Exposure Pathways to Biota

The first surveillance zone extends from near the operational areas to the site perimeter. The environmental concentrations of releases from facilities and fugitive sources (those released from other than monitored sources such as contaminated soils) generally would be the highest and, therefore, most easily detected in this zone. The second surveillance zone consists of a series of perimeter sampling stations positioned near or just inside the site boundary, along Highway 240 , which runs through the site from Richland to the Vernita Bridge, and along the Columbia River. Exposures at these locations are typically the maximum that any member of the public could receive. The third surveillance zone consists of nearby and distant community locations within an $80-\mathrm{km}$ radius of the site. Surveillance is conducted in communities to obtain measurements at locations where a large number of people potentially could be exposed to Hanford Site releases and to document that contaminant levels are well below standards established to protect public health. 
Background concentrations are measured at distant locations and compared with concentrations measured onsite and at perimeter and community locations. Background locations are essentially unaffected by site operations (i.e., these locations could be used to measure ambient environmental levels of chemicals and radionuclides). Comparing background concentrations to concentrations measured on or near the site indicates the impact of site operations.

To the extent possible, radiological dose assessments should be based on direct measurements of dose rates and radionuclide concentrations in environmental media. However, the amounts of most radioactive materials released from site operations in recent years generally have been too small to be measured directly once dispersed in the offsite environment. For the measurable radionuclides, often it was not possible to distinguish levels resulting from worldwide fallout and natural sources from those associated with Hanford Site releases. Therefore, offsite doses are estimated using the following methods:

- Doses from monitored air emissions and liquid effluents released to the Columbia River are estimated by applying environmental transport and dose-calculation models to measured effluentmonitoring data and selected environmental measurements. Pathway-modeling results are compared to measurable surveillance results to assess model performance, and the results of the comparison are documented. When measured results exceed model results, the measured results are used to adjust the dose results.

- Doses from fugitive air emissions (e.g., from unmonitored resuspended contaminated soils) are estimated from measured airborne concentrations at site perimeter locations.

- Doses from fugitive liquid releases (e.g., unmonitored groundwater seeping into the Columbia River) are estimated by evaluating differences in measured concentrations upstream and downstream from the Hanford Site.

\section{Annual Design-Review Process}

The design of surface environmental surveillance is reviewed annually based on the above considerations as well as an awareness of planned waste-management and environmental restoration activities. The process by which the design is evaluated is both continuous and cyclic. The need for changes in the surveillance design is evaluated continuously during the year in response to changing operations and/or environmental conditions. The design-review process repeats itself each year, using information generated during the previous year as the basis for the evaluation. The final sampling design and schedule are documented annually in the master sampling schedule (e.g., PNNL-11464). Key steps in the process are discussed below.

- pathway analysis - The process starts with the radiological pathway analysis performed by PNNL for the calendar year just ended. This analysis is based on a review and report of facility emissions and effluents provided by Waste Management Federal Services of Hanford, Inc. and PNNL facility managers and the environmental surveillance results from the previous year. The pathway analysis serves as the basis for the annual Hanford Site environmental report (e.g., PNNL-11472) as well as the design review.

- Hanford Site environmental report - The annual environmental report (e.g., PNNL-11472) summarizes the findings of the surveillance activities conducted during the previous calendar year. The 
evaluation of these results plays an integral part in the design evaluation, both in comparisons with the radiological and chemical pathway analyses conclusions and in identifying changes in environmental conditions that may indicate a need for modifications to the sampling plan. The distribution list for the annual report is reviewed to ensure that potentially affected federal, state, and local governments and agencies; Indian Nations; environmental interests; business interests; and owners of Hanford Reach islands are notified concerning the environmental status of the Hanford Site and its surroundings. Feedback on report contents and areas of concern relative to project design are considered in the design-review evaluation.

- site activity projection - Because the pathway analyses and the annual report are retrospective, an activity projection from the Hanford Site contractors identifies future activities to be considered in terms of surveillance needs. Resources useful in anticipating future environmental surveillance needs include DOE/RL-96-92, DOE/EM-0327, Ecology et al. (1989), various contractor effluent and operational environmental monitoring plans and results from previous years' monitoring, and bimonthly environmental monitoring and characterization technical exchanges between environmental surveillance personnel within each contractor.

- annual surveillance-design evaluation - The above information is considered in the annual surveillance-design evaluation as the basis for planning the surveillance program for the following few fiscal years and/or calendar years. Results of field inspections of sampling and measurement locations conducted during the current year are reviewed to determine whether conditions at sampling locations continue to meet siting and/or sampling design criteria. The design evaluation also includes a review for new surveillance-compliance requirements (e.g., DOE Orders, directives, or other applicable federal or state requirements) and DOE/EH-0173T updates. Plans for the following years are discussed with appropriate Hanford Site contractors to ensure that any assumptions implicit in the surveillance project about the availability of related ambient monitoring data are valid and to determine whether recent ambient data indicate conditions or trends that must be considered in the design of the surveillance project. The results of this annual surveillance-design evaluation and the action, if any, to be taken in response to changes are documented in the administrative files.

- submit scope and budget for upcoming fiscal years - Based on the results of the annual surveillancedesign evaluation, the scope and budget information is prepared and submitted for the following few fiscal years. Detail in the out-year scope and budget information is necessarily general in nature; however, it does provide targets on which to base future, more-detailed planning and specific scope and budget development.

- project documentation package for next fiscal year - Specific surveillance objectives, work scope, and budget are provided in the project-specific documentation package written for the upcoming (next) fiscal year. The package sets forth the plans and organization that will be used to conduct, control, and document the project and represents an agreement between DOE-RL and PNNL on the objectives, scope, and work to be performed during that fiscal year.

- scope and budget approval - As defined in the project-specific documentation package, the scope and budget are reviewed and approved by DOE-RL typically during the first half of the current fiscal year. Approval of the scope and budget is documented through DOE-RL signature on the current fiscal year package.

- surveillance design update - The annual surveillance-design evaluation is documented through updates to the project documentation package and the environmental surveillance master sampling 
schedule (e.g., PNNL-11464). Plans for the following calendar year are developed and discussed with other contractors to coordinate related activities. Plans are also discussed with representatives from the State of Washington Department of Health to identify those samples to be included in the cooperative duplicate sampling program.

- develop next calendar year master surveillance schedule - The master sampling schedule (e.g., PNNL-11464) for the next calendar year, based on the results of the annual design-review process, is prepared and issued.

- environmental monitoring plan update - This Environmental Monitoring Plan is reviewed annually and updated every $3 \mathrm{yr}$ (DOE Order 5400.1). Minor annual adjustments in sampling schedules, locations, or methodologies do not warrant revision of the plan but are documented in the project documentation package and master sampling schedule.

\section{Air Surveillance}

Radioactive particles and gases are released from point sources (stacks and vents) during routine operations in the $100,200,300$, and 400 Areas. Diffuse sources consist primarily of contaminated soil in the $100,200,300$, and 600 Areas that can be resuspended by wind. These materials are diluted to low concentrations as they are transported offsite where people may be directly exposed to radionuclides through inhalation or by deposition onto farm crops, native vegetation, and surface soil.

Each year, a radiological pathway analysis and exposure assessment is performed. Recent pathway analyses indicate that the site dose to the maximally exposed individual (below 0.05 mrem in 1996) is well below the level at which routine surveillance is recommended (DOE/EH-0173T). The predominant air pathways are inhalation and air-food.

The pathway analysis does not include the effects of resuspension of radionuclides from contaminated surfaces. Fission product and transuranic surface contamination exists in the 200 Areas, and uranium surface contamination exists in and around the 300 Area. There is also a large inventory of buried wastes in the 100,200, and 300 Areas that represents a potential source not addressed in the pathway dose assessment. Past monitoring data indicate that these sources currently do not represent significant sources for the air pathway. However, because of the large inventory, the potential for biointrusion, and the desire to provide a high level of public assurance, continued routine air surveillance of these source areas is considered necessary to provide an early indication of any loss of control. Each of these areas also contains Comprehensive Environmental Response, Compensation, and Liability Act of 1980 (CERCLA) operable units at which buried wastes will potentially be treated or removed in the future. Air surveillance at the margins of these operable units will provide baseline data before restoration actions (preoperational data) are taken, as well as data to assess the effects of restoration activities.

A review of DOE's site emergency response plans indicates that each of the four operating areas $(100,200,300$, and 400 Areas) has the potential to initiate a site emergency. Under that designation, there is a potential for an offsite dose of 50 to $1,000 \mathrm{mrem}$ EDE. At this level, there exists a need for near-facility air data to assess impacts resulting from potential accidents and unusual occurrences. To meet these special sampling needs, air samplers must be operated continuously. 
Public assurance is an essential element of surveillance at the Hanford Site. Although pathway modeling using operating facility source-term data is a useful tool, the public inherently has more confidence in actual environmental measurements. Sampling near the site perimeter, especially in the downwind sectors, provides data that are compared to background data to estimate the effect of the site at the closest point of actual or potential public residence, as well as to evaluate the pathway models and to estimate doses directly. Measurements in nearby communities provide assurance at those locations where the greatest number of people reside. In many cases, the environmental levels are currently below analytical detection limits. Exposures at the detection limits would result in doses that are a very small fraction of the dose standards.

\section{Objectives}

The objectives of air surveillance are the following:

- obtain air-concentration measurements at locations of actual and potential public residence to verify that doses to the public through the air pathway from DOE operations remain low relative to standards

- provide early detection of potential increases in public exposures and contamination of the environment through measurements of actual and potential emissions to the air from facilities and areas with surface contamination and buried wastes

- obtain preoperational baseline data and environmental surveillance data for areas near waste units scheduled for treatment and/or restoration to assess the integrated effects of individual site actions and over time

- obtain measurements at the site perimeter and in nearby communities to provide public assurance that the degree of contamination from DOE operations is known

- sample air onsite and offsite continuously to assess the environmental effects and doses from unusual releases

- provide data to evaluate and improve pathway models used to predict and assess public dose compliance and environmental contamination

- conduct surveillance for Fast Flux Test Facility technical specifications (HEDL 1981).

\section{Plan Rationale and Criteria}

The criteria for air sampling consist of those identified in DOE/EH-0173T. The actual level of surveillance and specific criteria to meet the site objectives are described below.

The locations, media, sampling frequencies, temporal and spatial compositing, analyses, and analysis frequencies to meet air-surveillance objectives and criteria are given in the annual sampling schedule (e.g., PNNL-11464). The 1997 sampling locations are provided in Figure III.A-3. Sample locations may change annually. The rationale and any additional specific criteria for these selections are discussed below. 


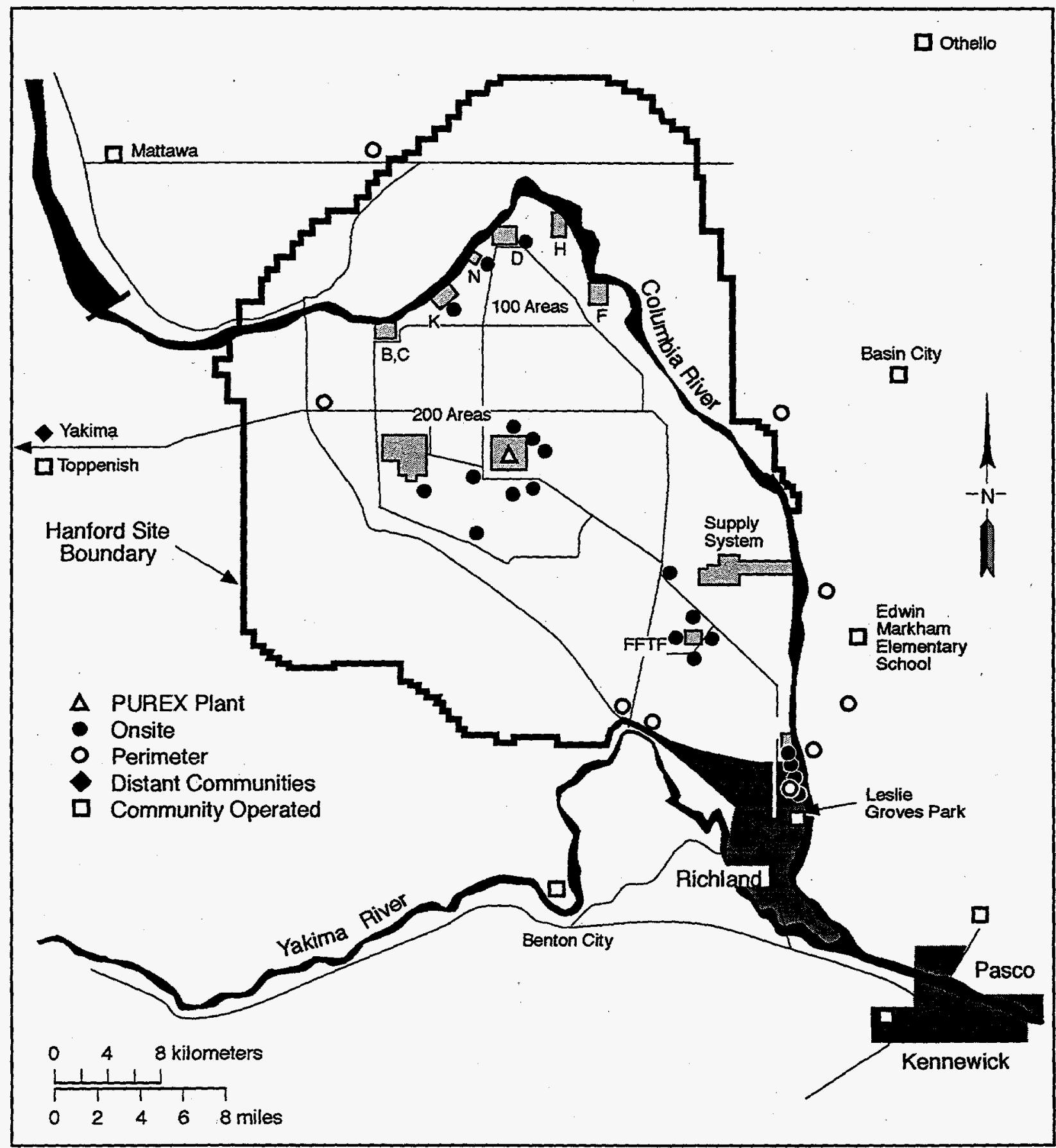

SG97090082.2

Figure III.A-3. Air-Sampling Locations

\section{Media Selection}

Air is sampled according to the primary form in which the radionuclides occur. Most of the radionuclides of interest occur in particulate form at the site. Past measurements indicate that iodine occurs predominantly as a gas and tritium as water vapor. 


\section{Analyte Selection}

Onsite. Air samples collected downwind near each operating area are field surveyed for alpha and beta-gamma radioactivity with hand-held instruments at the time of collection to verify normal conditions or to detect unusual conditions should they occur. These samples are then analyzed for gross alpha and beta activity after natural activity has decayed to provide an indication of the levels of contaminants present. The samples are then composited and analyzed for those radionuclides routinely released in measurable quantities as indicated by facility emissions data, for those with potential to be released under plausible abnormal conditions, for those calculated to contribute more than $10 \%$ of the maximally exposed individual dose, and for those of special public or agency interest. These criteria encompass those radionuclides considered necessary to meet technical and public assurance objectives. Compositing and screening techniques may be used to improve detection levels and reduce analysis requirements where screening provides adequate surveillance.

Perimeter. Additional samples are collected near the perimeter of the site, in the downwind direction, and are used to assess operational control and effects of unusual events. These samples are field surveyed and laboratory analyzed for gross alpha and gross beta and are composited to enhance detection sensitivity for gamma-emitting radionuclides and other radiochemical analyses.

Offsite. Samples from the historical maximally exposed individual locations and downwind contaminants are analyzed for measurable radionuclides, those contributing more than $10 \%$ of the maximally exposed individual dose, and those of special public or agency interest.

\section{Sampling and Analysis Frequency}

Sample locations are visited every other week. Site experience indicates that particulate filters must be collected at this frequency to avoid excess particulate buildup on the filters. Particulates are analyzed for gross alpha and gross beta every other week to provide early indication of any loss of control that may require expedited analysis of samples and/or additional or special sampling. Gamma scans are analyzed quarterly to track trends that are not likely to be detectable in gross activity measurements. Radiochemical analyses (i.e., isotopic uranium, isotopic plutonium, and ${ }^{90} \mathrm{Sr}$ ) of filters are performed annually to provide data to estimate or bound the human annual dose standards.

Iodine-131 charcoal cartridge samples are no longer routinely collected. With the shutdown of all reactors and fuel reprocessing, there is no active DOE source of this radioisotope. Any ${ }^{131} I$ released to the environment from past DOE operations would have decayed to undetectable amounts.

Iodine-129 charcoal cartridges and tritium silica gel columns are collected monthly. This is an operationally practical sampling period and has been observed to be short enough to preclude significant breakthrough and loss of sample. Samples are analyzed monthly for tritium. Iodine-129 is the leading contributor to dose through the air pathway. Monthly samples are composited and analyzed quarterly near the source (200-East Area) and at the perimeter and background locations to track shorter-term. trends.

Background locations are sampled for a given constituent at the highest frequency the constituent is sampled onsite or offsite so that data can be compared and analyzed on the same time scale. The sampling schedule is evaluated and prepared annually. 


\section{Sampling Location Selection}

Onsite. Downwind of each operating area with significant inventories of nuclear materials, an air sampler is located as near the climatologically predicted maximum impact area as is practical (considering access, power availability, and costs). Additional samplers are located around those areas to increase the likelihood of detecting an unusual occurrence. These additional samplers are distributed azimuthally by wind-direction sector, balancing considerations of wind-direction frequencies, geometric distribution, and practicality. Radial placement is based on the predicted distance of maximum ground-level impact for Class E atmospheric stability (slightly stable) (from Turner 1970, Figure 3-9) to the extent practical. The goal of placing samplers at the Class E stability maximum ground-level impact distance is a compromise between the desire to sample at the point of maximum ground-level concentration for all stabilities; the desire to be far enough away that an elevated plume will reach the ground at the sampler under all conditions; and the practical recognition that, in general, power is available near the facilities and much less available at increasing distance from the facilities.

Samplers are located with the goal of providing measurements representative of the integrated effects of the areas being monitored, a goal that may require a tradeoff with the goal of measuring the maximum effects.

Perimeter. Additional stations at the perimeter of the site are located to reflect the distribution of source areas across the site.

Offsite. Offsite samplers are located near the maximally exposed individual location to attempt to verify such exposures; in the nearest downwind population center, the Tri-Cities, to bound the maximum exposures at the nearest population center and at the highest frequency wind-direction sectors. In addition, samplers are located in a few selected downwind communities to provide means for public involvement, education, and assurance.

At least one background location a minimum of $20 \mathrm{~km}$ from the site in a predominantly upwind direction is sampled for each radionuclide, form, and species sampled onsite or offsite.

Proximity to Obstructions. Samplers are located to obtain concentration measurements representative of open areas (i.e., avoiding significant local effects on the radionuclide concentrations of interest such as those caused by building wake entrainment and vegetation filtration). This approach is expected to provide better comparability of data between locations.

Samplers are placed outside building wake zones, where aerodynamic effects could significantly affect the observed concentrations. This can occur when elevated plumes pass over structures and are entrained and mixed into the wake or when plumes are of the same order or size as the structures they impinge upon. In the latter case, plumes will have a strong concentration gradient, and mixing by a wake can significantly change the concentrations that would otherwise have been observed. After elevated plumes have contacted the ground and at distances where the lateral dimensions of the plume are large compared to structures, the effects of the structures on air concentrations about the structures can be expected to be small because the concentration gradients in the air approaching the structure are small. To implement this qualitative model, samplers are located at a distance that is at least three times the height of the building away from the nearest building unless:

- the sampling point is farther from the source than the predicted distance for the ground-level maximum concentration for the applicable effective stack height under Class $\mathrm{F}$ atmospheric stability (from Turner 1970, Figure 3-9) 
- the lateral plume width (4 $x$ oy from Turner 1970, Figure 3-2) under Class $\mathrm{F}$ atmospheric stability (moderately stable) conditions is at least 10 times $\mathrm{L}$, where $\mathrm{L}$ is the largest dimension of the building.

Samplers near trees or other elevated vegetation can be influenced by the same effects. Isolated trees can be expected to cause less flow obstruction but can represent greater sinks for some radionuclides. Based on these considerations, samplers are placed at a distance at least two times the height of isolated trees and at three times the height of rows or stands of trees at all locations.

Application of these criteria is necessarily constrained by accessibility and the cost of providing electrical power. At some locations, it may not be practical to meet the desired criteria.

Sampling inlets are located $2 \mathrm{~m}$ above the ground to provide measurements representative of radionuclide concentrations inhaled by humans.

\section{Sampling or Measurement Method Selection}

Particle sampling is accomplished with glass fiber filters with manufacturer's documentation of a sampling efficiency of at least $99 \%$ for 0.3 -micron dioctyl phthalate particles at the flow rate being used $\left(2.6\right.$ to $\left.5.2 \mathrm{~m}^{3} / \mathrm{h}\right)$.

When ${ }^{131}$ I analysis might be necessary, samples are collected on activated charcoal with manufacturerdocumented collection efficiencies for the flow rate $\left(2.6 \mathrm{~m}^{3} / \mathrm{h}\right)$, bed depth $(2.5 \mathrm{~cm})$, and exposure periods used (14 d). Samples for ${ }^{129} \mathrm{I}$ analysis are collected on petroleum-based (low-background) charcoal specially prepared by PNNL; the collection efficiency is verified; and the flow rate is $2.6 \mathrm{~m}^{3} / \mathrm{h}$, with a bed depth of $2.5 \mathrm{~cm}$, and an exposure period of $28 \mathrm{~d}$. Both types of iodine sample traps are preceded in the sampling train by a disposable filter to remove particles.

Samples for tritium analysis are collected on silica gel for identifying the tritiated water in air component. Flow rates $\left(0.011 \mathrm{~m}^{3} / \mathrm{h}\right)$, media volumes, and exposure periods ( $28 \mathrm{~d}$ ) are such that the media are not likely to be saturated during the sampling period. Silica gel saturation is monitored using a colorchange indicator, which is useful in diagnosing sampling problems.

Flow rates for air samples are measured at the beginning and end of each sampling period with a device with a documented accuracy of $\pm 20 \%$.

\section{Sample-Handling/-Treatment Methods}

Air samples are collected in a manner that avoids loss of sample mass, crosscontamination, or misidentification. This is accomplished by exchanging whole sample collection media containers, rather than handling the collection media in the field, and by labeling and sealing or storing each sample so that sample integrity as it is collected in the field is maintained. Sample-collection and -handling procedures are described in PNL-MA-580, Rev. 2.

\section{Analytical Methods}

Analytical methods are selected to meet the minimum goal of detecting levels equivalent to a dose of $1 \mathrm{mrem}$ if that concentration were sustained for a year. An additional goal is to achieve the lowest detection levels available using standard state-of-the-art analytical methods. The detection levels and analytical methodology are summarized in the subsection entitled Laboratory Procedures. 


\section{Quality Control Methods}

Air surveillance is controlled under the overall project quality assurance and analytical control program described in the subsection entitled Quality Assurance and Quality Control.

\section{Reporting/Alarm Levels}

Anomalous results are flagged by computer screening of reported data as they are entered into the project database. Levels for reporting to DOE-RL have been established and are listed in the subsection entitled Records Management and Reporting. Reporting levels are equivalent to the concentration that might lead to a maximally exposed individual dose of $1 \mathrm{mrem}$ EDE if it were sustained for a year. This reporting level provides early indication of conditions that might eventually require reporting to DOE-HQ, as required by DOE Order 5400.5 .

\section{Exceptions}

No exceptions have been taken to should* statements in DOE/EH-0173T.

\section{Surface-Water Surveillance}

The Columbia River flows through the northern edge of the Hanford Site and forms part of the site's eastern boundary. The Hanford Reach of the Columbia River extends from Priest Rapids Dam to the head of Lake Wallula (the impoundment created by McNary Dam). Priest Rapids Dam is the nearest dam upstream of the site and McNary Dam is the nearest downstream.

In addition to the Columbia River, other surface waters exist at the Hanford Site. These include a naturally occurring pond (West Lake), Rattlesnake Springs, and two intermittently flowing streams (Dry and Cold Creeks), as well as other small springs on the Fitzner/Eberhardt Arid Lands Ecology Reserve. Riverbank springs (i.e., groundwater discharge) occur along the Hanford Reach of the Columbia River as well. Other surface waters include several artificial waste-disposal ponds and a series of ditches also associated with waste-disposal practices at the Hanford Site.

The Columbia River has been developed extensively for hydroelectric power, flood control, navigation, irrigation, and industrial water supplies. The river is used as a source of drinking water at onsite facilities as well as at communities located downstream of the site. In addition, the river and its shoreline are used for a variety of recreational activities, including hunting, fishing, boating, water skiing, wind surfing, picnicking, and swimming.

Pollutants resulting from past and current operations at the Hanford Site, both radiological and nonradiological, are known to enter the Columbia River. In addition to U.S. Environmental Protection Agency (EPA)-permitted direct discharges of liquid effluents from onsite facilities, contaminants from past waste-disposal practices seep into the river through riverbank springs and subsurface groundwater discharges. 
The surface-water pathway (Columbia River) has consistently been one of the primary contributors to the potential dose received by the public as a result of operations at the Hanford Site.

Discharges to the Columbia River and onsite waste-disposal ponds are monitored by Fluor Daniel Hanford, Inc. (and its enterprise companies). Requirements of DOE/EH-0173T identify the need for monitoring two media in the pathway of concern (one of which can be the effluent) as part of the routine surveillance program. As such, periodic sampling of the onsite waste-disposal ponds is conducted as part of the surface surveillance conducted by PNNL. Such sampling also provides a means of verifying existing effluent-control and effluent-monitoring systems. Unplanned releases may also be detected through routine sampling of these media.

Site-specific surveillance identified the need to maintain elements of the program to evaluate longterm trends and to detect changes in environmental conditions as a result of Hanford Site operations. In addition, it is essential that the location and concentrations of contaminants entering the Columbia River be known. Periodic sampling of riverbank springs verifies the levels of contaminants identified in the local groundwater and confirms the discharge of certain constituents into the river. Activities designed to provide these capabilities are maintained as appropriate.

The State of Washington classified the stretch of the Columbia River from Grand Coulee Dam to the Washington-Oregon border, which includes the Hanford Reach, as Class A, Excellent (Washington Administrative Code [WAC] 173-201A). Water quality criteria and water use were established in conjunction with this designation. Water quality monitoring is necessary to determine compliance with these criteria.

The Columbia River and the potential impact of Hanford Site operations on the quality of river water have received increasing public scrutiny and concern during recent years. Public-interest groups conducted surveillance along the Hanford Reach and raised many questions and concerns. Surface watersurveillance activities initiated in the past to address such public concerns and to provide public reassurance will be continued.

\section{Objectives}

The objectives of the surface water-surveillance activities include the following:

- assess impacts of Hanford Site operations on the water quality of the Columbia River

- identify significant changes in the concentrations of contaminants (radiological and chemical) in surface water

- verify adequacy of effluent monitoring and controls

- characterize contaminants in the surface-water environment

- determine status of compliance with applicable water quality standards

- provide public reassurance that risks associated with the use of the Columbia River are low and are being evaluated on a continuous basis. 


\section{Plan Rationale and Criteria}

The basis for the design of the surface water-surveillance program is discussed in DOE/EH-0173T. In addition, other environmental monitoring guides and references were considered in the development of the Hanford Site's surface water-surveillance program. Similarly, references and guidance specific to water quality monitoring and water sample collection were used in sampling protocols.

The surface water-sampling plan is summarized annually (e.g., PNNL-11464). The media, locations, sample types, frequency, and analyses are included in the sampling schedule.

All surface-water samples are collected in accordance with documented, reviewed, and approved collection procedures. Applicable sample-collection procedures are described in PNL-MA-580, Rev. 2. As part of the overall Hanford Site environmental monitoring effort, selected duplicate samples are collected with the State of Washington Department of Health (see PNNL-11464).

\section{Media Selection}

As previously discussed, contaminants are known to enter the Columbia River as a result of past and current operations at the Hanford Site. Consumption of water or biota from the Columbia River or foodstuffs produced on land irrigated with river water could expose the public to these contaminants. Similarly, public exposure could occur by direct exposure from water recreation. The Columbia River is routinely monitored to measure the potential exposure from these pathways.

Riverbank springs (groundwater discharge) containing contaminants enter the river along the Hanford Reach. The springs are monitored periodically to document the locations and levels of contaminants entering the river. Such monitoring also confirms the findings of the Groundwater Monitoring Project relative to the extent of the contaminated groundwater plumes at the Hanford Site.

Onsite ponds, while not directly accessible to the public, are used by migratory waterfowl and wildlife that could migrate off the site and be harvested and consumed by the public. Onsite ponds are monitored to determine the potential for exposure to the public from this pathway.

Offsite irrigation water may be impacted by site operations. Public concerns with respect to the quality of irrigation water systems and the potential for degradation as a result of site activities have been expressed. Periodic monitoring provides reassurance that irrigation water quality is not impacted by Hanford Site operations.

The following provides a description of the monitoring activities specific to each medium identified above.

\section{Columbia River}

Analyte Selection. Columbia River water samples are analyzed for those constituents that, as determined by pathway analyses, represent a significant fraction of the potential dose from the water pathway. In addition, contaminants of public concern are included in the analyses. In general, analyses include those contaminants known or suspected to be present in the river water as a result of past or 
current Hanford Site operations. In those cases where constituents have been documented to be consistently below measurable levels, they have been removed from the sampling plan.

Radiological analyses of water samples include gross alpha, gross beta, gamma scan, tritium, isotopic uranium, ${ }^{90} \mathrm{Sr},{ }^{99} \mathrm{Tc},{ }^{129} \mathrm{I}$, and ${ }^{239,240} \mathrm{Pu}$. Gross alpha and gross beta measurements provide a general indication of the radioactive contamination. Gamma scans provide the ability to monitor for numerous specific gamma-emitting radionuclides, including ${ }^{60} \mathrm{Co},{ }^{106} \mathrm{Ru},{ }^{125} \mathrm{Sb},{ }^{137} \mathrm{Cs}$, and ${ }^{154} \mathrm{Eu}$, as well as others. Highly sophisticated radiochemical analytical techniques and, in some cases, special sampling techniques are used to determine the concentrations of tritium, ${ }^{90} \mathrm{Sr},{ }^{99} \mathrm{Tc},{ }^{129} \mathrm{I},{ }^{234} \mathrm{U},{ }^{235} \mathrm{U},{ }^{238} \mathrm{U}$, and ${ }^{239,240} \mathrm{Pu}$ in river water. Radionuclides of interest are selected based on their importance in determining water quality, in verifying effluent-control and -monitoring systems, and in determining compliance with applicable standards. Where warranted, the half-lives of specific radionuclides are considered in determining sampling and analysis frequencies.

Chemical contaminants analyzed for in water samples include volatile organic compounds, metals, and anions. In addition to monitoring conducted by PNNL, water quality measurements are also performed by the U.S. Geological Survey in conjunction with the National Stream Quality Accounting Network (NASQAN). The U.S. Geological Survey samples are analyzed for numerous physical, biological, and chemical constituents, including temperature, $\mathrm{pH}$, turbidity, dissolved oxygen, suspended solids, dissolved solids, conductivity, hardness, alkalinity, phosphorus, chromium, iron, and nitrate.

Sampling Location Selection. Routine Columbia River water sample-collection locations are identified in Figure III.A-4. Samples are collected upstream of Hanford Site facilities at Priest Rapids Dam and near the Vernita Bridge to provide background data from locations unaffected by site operations. Samples are collected downstream of Hanford Site facilities at the Richland Pumphouse to identify any increase in contaminant concentrations caused by site operations. The Richland Pumphouse, operated by the City of Richland, is the first downstream point of river-water withdrawal for a public drinking water supply. As such, this location provides an upper estimate of the amount of radioactive material in the water supply of the potentially affected population group(s) downstream of the Hanford Site.

Priest Rapids Dam is located $\sim 8 \mathrm{~km}$ upstream of the site boundary and $20 \mathrm{~km}$ upstream of the 100-B,C Area. The water sampler at Priest Rapids Dam is positioned approximately midstream within the dam and collects water from the reservoir behind the dam. The Vernita Bridge sampling location is $\sim 6 \mathrm{~km}$ upstream of the 100-B Area.

The Richland Pumphouse is located $\sim 3 \mathrm{~km}$ downstream of the site boundary and $\sim 5 \mathrm{~km}$ downstream of the effluent discharge farthest downstream. The water-sampling intake is located with the City of Richland drinking water supply intake on the Benton County shoreline, $\sim 9 \mathrm{~m}$ into the river. Historical environmental monitoring reports indicate this to be the drinking water supply having the maximum radionuclide concentrations downstream of the Hanford Site (BNWL-90, BNWL-316, BNWL-439, BNWL-983, BNWL-1341, BNWL-1505, BNWL-1669, HW-80991). Past sampling along transects near this location indicated that concentrations of gross beta activity and tritium are slightly elevated near the Benton County shoreline (HW-69369, PNL-8531). In 1997, water samples collected at the Richland Pumphouse had statistically elevated concentrations of tritium and ${ }^{129} \mathrm{I}$ compared to samples collected at Priest Rapids Dam (PNNL-11472).

Transect sampling is conducted near the Vernita Bridge, 100-N Area, 100-F Area, Old Hanford Townsite, 300 Area, and Richland Pumphouse. Transect sampling is performed to determine the 


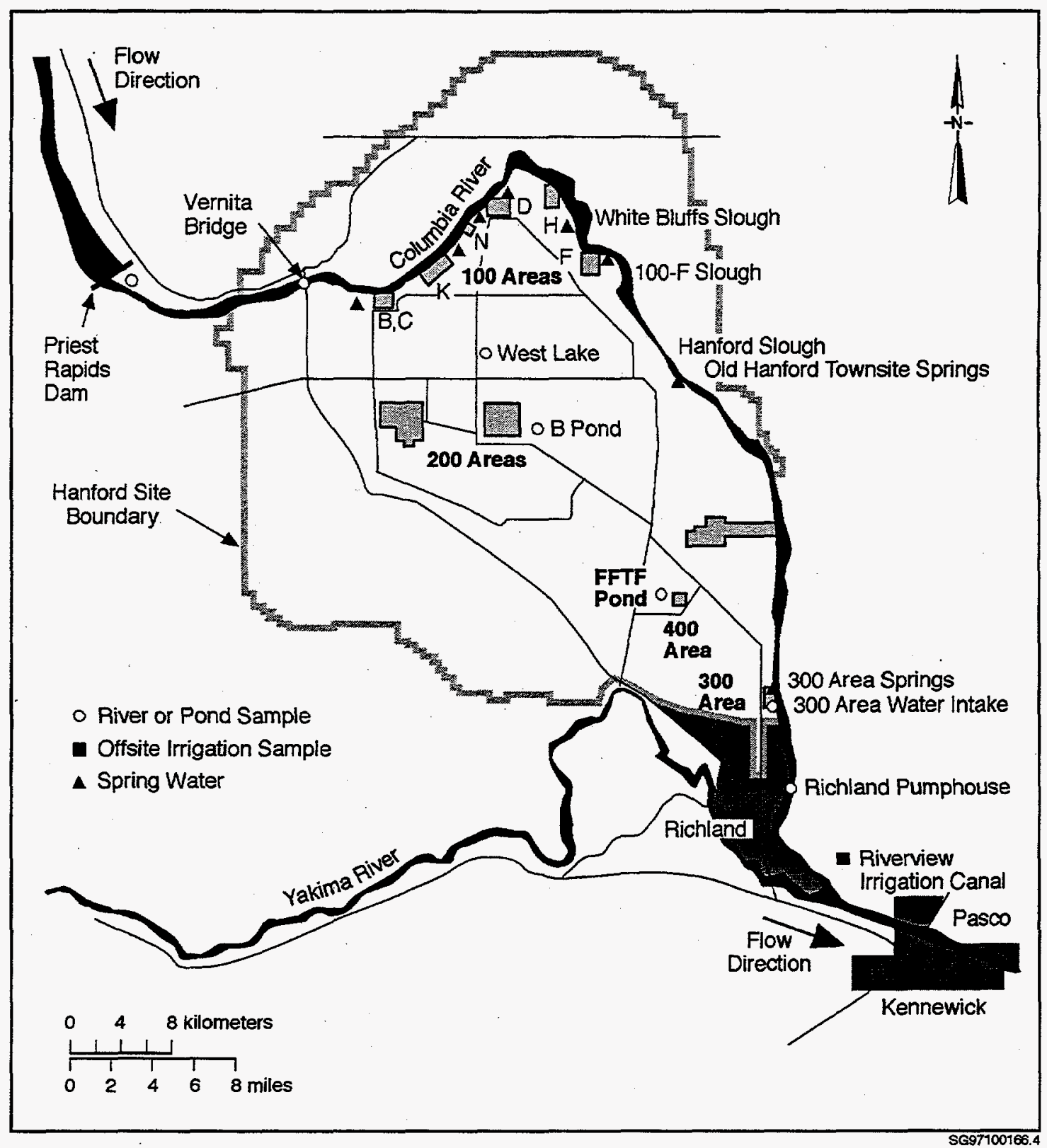

Figure II.A-4. Surface Water-Sampling Locations

distribution of contaminants across the river at these locations. In addition, transect sampling is used to determine the localized zone of influence near known discharges of contaminated groundwater via riverbank springs. The representativeness of the single-point-intake sampling system located at the Richland Pumphouse is also evaluated using results of the transect sampling. Samples along the transects are collected at approximately mid-depth and at several points (up to 10) across the river. Transect sampling will identify those contaminants that are measurable in the river and which may be influenced by proximity to the contaminated groundwater plume.

Sampling or Measurement Methods Selection. The sample types, collection method, sample size, and sample and analysis frequency are discussed below. The selection of sampling methods and 
equipment depends on the potential for fluctuations in contaminant concentrations, variability in the effluent release into the receiving water, potential for significant environmental or human impact, and characteristics of the contaminant of interest.

Two types of water-sampling systems are used to collect radiological samples: 1) a cumulative system that collects a fixed volume of water at set intervals at each location during each sample period and 2) a specially designed system that continuously collects waterborne radionuclides from the river on a series of filters and mixed-bed ion-exchange resin column. Flow-proportional sampling is desired; however, because of the extremely large size of the Columbia River, such a system is not practical. Manual composites are collected in those cases where the use of automatic units is not feasible and to cover periods of equipment downtime. Sample size is determined by the requirements of the analytical method to be used and the required levels of sensitivity.

Cumulative sampling systems are operated at Priest Rapids Dam and the Richland Pumphouse and consist of timer-activated units that periodically collect water from a continuously flowing substream of Columbia River water into a 10-L container. The sample sequence includes a pre- and post-subsample air purge to avoid crosscontamination between the individual sample aliquots. The cycle is repeated throughout a 1-wk sample period at Priest Rapids Dam and Richland Pumphouse, such that $\sim 55 \mathrm{~mL}$ of water are collected every hour. The 10-L sample container is changed every week, and the sample is taken to the laboratory, where water from each location is composited over a 4-wk period, resulting in a total sample size of $\sim 40 \mathrm{~L}$. Analyses are performed on these samples according to the current sampling schedule (e.g., PNNL-11464).

Continuous sampling systems are located at Priest Rapids Dam and Richland Pumphouse. A special, continuously flowing system is used to separate radionuclides from the river water before analysis. A large volume of water is required to allow the extremely small concentrations of these radionuclides to be detected. River water is pumped through the collection system at a rate of $\sim 50 \mathrm{~mL} / \mathrm{min}$, resulting in a total sample volume of $\sim 1,000 \mathrm{~L}$ during each 2 -wk sampling period. Suspended particles $>0.45 \mu \mathrm{m}$ in diameter are removed on a series of filters. Soluble radionuclides, except tritium, are collected on a mixed-bed ion-exchange resin column. The filters and ion-exchange resin are changed every 2 wk, composited by location, and analyzed on a quarterly basis according to the current sampling schedule (e.g., PNNL-11464).

Grab samples of Columbia River water are collected quarterly or annually along crosssections at transect sites near the Vernita Bridge, 100-N Area, 100-F Area, Old Hanford Townsite, 300 Area, and Richland Pumphouse for analyses of various radiological and nonradiological water quality parameters. The requirement for minimum holding and transport times prohibits the use of composite systems for these analyses. Special care is taken to obtain water from a flowing portion of the river, avoiding stagnant backwater areas. Surface debris and bottom sediment are also avoided during sampling by collecting the samples from approximately mid-depth. Samples are delivered to the laboratory, where processing is initiated promptly to ensure sample integrity. Samples are analyzed according to the current sampling schedule (e.g., PNNL-11464).

In addition to monitoring conducted by PNNL, water quality measurements are also performed by the U.S. Geological Survey at Vernita Bridge and Richland. These samples are collected every other month at the Vernita Bridge and quarterly at Richland. Numerous physical, biological, and chemical constituents are analyzed for by their laboratory in Denver, Colorado. In addition to sampling, the U.S. Geological Survey provides flow-rate measurements at the Priest Rapids Dam gauging station, near the upstream boundary of the site. 
Sample-Handling/-Transport Methods. Surface-water samples are collected in such a manner as to ensure that the sample is representative of the body of water being sampled. Steps are incorporated in the sampling procedure to avoid misidentification and crosscontamination of the samples being collected. Quality assurance is established and implemented by PNNL's Standards-Based Management System (PNNL 1997). Chain-of-custody procedures, to ensure the integrity of the sample throughout the collection-transport-analysis process, are detailed in PNNL (1997) and PNL-MA-580, Rev. 2.

Analytical Methods. Analytical methods are selected to meet the minimum goal of detecting levels equivalent to a dose of $1 \mathrm{mrem}$ if that concentration were sustained for a year. An additional goal is to achieve the lower detection levels available using standard state-of-the-art analytical methods. These goals are summarized in the Laboratory Procedures subsection. In some cases, special techniques have been developed and are used to measure specific contaminants known to be discharged into the surface waters. Analytical methods and detection limits are summarized in the Laboratory Procedures subsection.

\section{Riverbank Springs}

Routine riverbank spring sample locations were given in Figure III.A-4. Samples are collected annually along the shoreline of the 100-B,C Area, 100-K Area, 100-N Area, 100-D Area, 100-H Area, 100-F Area, downstream of the Old Hanford Townsite, and at the 300 Area. Groundwater enters the Columbia River at these locations, with contaminant levels significantly higher than background.

Water samples collected at these locations are analyzed for those constituents known or suspected to be present in the local groundwater. The primary radionuclides of concern include tritium, uranium, ${ }^{60} \mathrm{Co},{ }^{90} \mathrm{Sr},{ }^{99} \mathrm{Tc}$, and ${ }^{129} \mathrm{I}$. Chemical contaminants of concern include metals (primarily chromium), volatile organic compounds, and anions.

Samples are typically collected using a siphon pump directly in an improved discharge zone to avoid agitation of the sediments. The sampling zone of the riverbank spring is improved by scooping the sediment away from the discharge area and allowing the disturbed sediments to settle before the siphon pump is used. Riverbank spring samples are handled and transported in a manner similar to the riverwater samples discussed above.

\section{Onsite Ponds}

Sampling Locations. Three onsite ponds (see Figure III.A-4), located near operating areas, are routinely sampled. B Pond, located near the 200-East Area, was excavated in the mid-1950s for disposal of process cooling water and other liquid wastes occasionally containing low levels of radionuclides. West Lake, located north of the 200-East Area, is recharged from groundwater (ARH-CD-775). This lake has not received direct effluent discharges from site facilities, and radionuclide concentrations are influenced by the local groundwater. The Fast Flux Test Facility Pond, located near the 400 Area, was excavated in 1978 for the disposal of water from various facilities in the 400 Area. The volume of water present in all of the onsite ponds has been decreased significantly during recent years as a result of changes in liquid effluent-disposal practices. In addition, site plans call for the elimination of discharges of liquid effluents to the ground in the near future. As such, sampling of these ponds is becoming more difficult with time and the need for continued monitoring may be diminished, if not eliminated.

Fluor Daniel Hanford, Inc. (and its enterprise companies) is responsible for monitoring effluents discharged to the ponds and for operational surveillance of the ponds (HNF-EP-0573-5). 
Sample Collection and Analysis. Grab samples $(10 \mathrm{~L})$ are collected quarterly from each pond. Care is taken to avoid surface debris and resuspension and inadvertent collection of bottom sediments. Unfiltered aliquots of the samples are analyzed for gross alpha and gross beta activities, gamma-emitting radionuclides, tritium, ${ }^{90} \mathrm{Sr}$, and ${ }^{99} \mathrm{Tc}$ according to the current sampling schedule (e.g., PNNL-11464).

\section{Offsite Irrigation Water}

Samples are collected from an irrigation canal that obtains water from the Columbia River downstream of the Hanford Site (see Figure III.A-4). Consumption of food irrigated with Columbia River water from downstream of the site was identified as a pathway contributing to the potential dose to the hypothetical maximally exposed individual in 1996 (PNNL-11472).

The Riverview Irrigation Canal is sampled and analyzed for total alpha, total beta, gamma emitters, tritium, ${ }^{90} \mathrm{Sr} ;{ }^{234} \mathrm{U},{ }^{235} \mathrm{U}$, and ${ }^{238} \mathrm{U}$ according to the current sampling schedule (e.g., PNNL-11464). Strontium- 90 is the primary radionuclide of concern because it was identified as one of the primary contributors to the calculated hypothetical dose to the public via the water pathway (PNL-6464).

\section{Quality Control Methods}

Surface-water surveillance is controlled under the overall project quality assurance and analytical control program described in the subsection entitled Quality Assurance and Quality Control.

\section{Reporting/Alarm Levels}

Anomalous results are flagged by computer screening of reported data as they are entered into the project database. Levels for reporting to DOE-RL have been established and are listed in the Records Management and Reporting subsection. Reporting levels are equivalent to the concentration that might lead to a dose of 1 mrem EDE to the maximally exposed individual if it were sustained for a year. This reporting level provides early indication of conditions that might eventually require reporting to DOE-HQ as required by DOE Order 5400.5 .

\section{Exceptions}

No exceptions have been taken to should* statements in DOE/EH-0173T.

\section{Sediment Surveillance}

As a result of Hanford Site operations, large quantities of radioactive materials were discharged to the Columbia River. On release to the river, the radioactive materials were dispersed rapidly, sorbed onto inorganic particles and detritus, incorporated into aquatic biota, and deposited on the riverbed as 
sediment. Fluctuations in the river-flow rate, as a result of the operation of hydroelectric dams, annual spring freshets, and occasional floods, have resulted in the resuspension, relocation, and redeposition of the contaminated sediments.

Since the shutdown of the original single-pass cooling reactors, the radionuclide burden in the riversurface sediments has been decreasing as a result of radioactive decay and subsequent deposition of uncontaminated material. However, discharges of some radionuclides to the Columbia River still occur through the seepage of contaminated groundwater into the river. It is expected that some of these radionuclides are either deposited directly or sorbed onto the sediment materials and deposited on the river bottom.

The accumulation of radioactive materials in sediment can lead to exposure of humans through ingestion of aquatic species, through sediment resuspension into drinking water supplies, or as an external radiation source irradiating people fishing, wading, sunbathing, or participating in other recreational activities associated with the river and shoreline.

Public exposures are well below the level at which routine surveillance of the sediments is required (DOE/EH-0173T). However, periodic sampling is necessary to confirm the low levels and to ensure that no significant changes have occurred over time that may increase the potential exposure to the public through this pathway.

Sampling on a routine basis is necessary to meet site-specific surveillance requirements (DOE/ EH-0173T). It is imperative that the whereabouts and fate of the contaminants known to enter the river along the Hanford Reach be understood. Because the source of radionuclides entering the river is predominantly the seepage of contaminated groundwater, sampling of the sediments and river water near the discharge zones provides an indication of the levels entering the river and also confirms findings of the Groundwater Monitoring Project conducted at the Hanford Site.

Public concern about the levels of contamination in the river sediments and the potential for these contaminants to be resuspended and relocated, perhaps in areas of public use, is evident in the Hanford Site area. Routine sampling of the sediment material provides the public a degree of assurance that both the potential problem (resuspension and redistribution of contaminated sediment) and their concerns are being considered and addressed appropriately.

\section{Objectives}

The objectives of the sediment-surveillance activities, consistent with overall surface environmental surveillance, include the following:

- verify that doses caused by Hanford Site operations through this pathway remain low, by means of periodic river-system evaluation, sampling, and analysis

- provide an indication of changes in environmental conditions with potential for increases in public exposures

- provide public assurance in the credibility of site surveillance and that the radiological conditions and potential exposure pathways are understood and receive appropriate attention. 


\section{Plan Rationale and Criteria}

The basis for sampling sediments from surface waters is discussed in DOE/EH-0173T. In addition, other environmental monitoring guides and references have been considered in the development of the sediment-sampling plan. The locations, sampling frequency, and analyses performed routinely on sediment samples are summarized annually (e.g., PNNL-11464). Additional rationale and specific criteria are described below.

\section{Media Selection}

Sediments along the Hanford Reach are known to contain elevated concentrations of radionuclides and produce higher-than-normal levels of external radiation. Contaminants in sediments may lead to public exposure through the ingestion of aquatic species, through sediment resuspension into drinking water systems, and as an external radiation source. Sediment sampling and the measurement of external radiation emanating from the sediments provide indications of the potential for human exposure from this pathway. Sediments are sometimes more sensitive indicators of waterborne contaminants than water or aquatic biota because some contaminants may accumulate in sediments.

All sediment samples are collected in accordance with documented, reviewed, and approved collection procedures contained in PNL-MA-580, Rev. 2. Analytical methods are summarized in the subsection entitled Laboratory Procedures.

\section{Analyte Selection}

Sediment samples are analyzed for contaminants known or suspected to be present as a result of past or current operations at the Hanford Site. Effluent discharge reports are reviewed to identify contaminants currently entering the river. Groundwater-monitoring reports identify those contaminants near the river and potentially entering the river that must be considered in the sampling plan. Historic reports, documenting past releases or sediment-contaminant concentrations, are reviewed to determine contaminants of concern as a result of past operations.

Sediment samples are routinely analyzed for gamma-emitting radionuclides (gamma scan), ${ }^{90} \mathrm{Sr},{ }^{235} \mathrm{U}$, ${ }^{238} \mathrm{U}$, ${ }^{238} \mathrm{Pu}$, and ${ }^{239,240} \mathrm{Pu}$, according to the current sampling schedule (e.g., PNNL-11464). Such analyses are consistent with past and current releases and historical data relative to contaminants in the sediments. In addition, sediment samples are routinely analyzed for metals.

\section{Sampling Frequency}

Sampling of sediments is conducted on an annual basis. This is deemed satisfactory because the sediments are not in a critical exposure pathway to the public. Sampling is conducted consistent with spring freshets (i.e., sampling occurs after the spring high water to provide a consistent and more easily interpreted information base).

Core samples, to determine the fate and buildup of contaminants in the sediment over time, may be collected periodically, commensurate with findings of past core-sampling activities and in consideration of future activities that may resuspend and redistribute the sediment. 


\section{Sampling Location Selection}

Samples of Columbia River sediment are collected at the locations shown in Figure III.A-5. Samples are collected upstream of the Hanford Site (beyond the influence of Hanford Site facilities) behind Priest Rapids Dam. Samples are collected downstream of the Hanford Site at Richland and behind McNary Dam (the nearest downstream impoundment). Four samples are collected behind each of the dams at approximately equal distances along a sample transect. This provides additional information relative to the distribution of contaminants in the sediments across the river. In addition, samples are collected along the Hanford Reach, at locations nearer the discharges (past and current), in areas where material is known to be deposited, and in areas commonly used by the public. These locations include the White Bluffs, 100-F, and Hanford Sloughs.

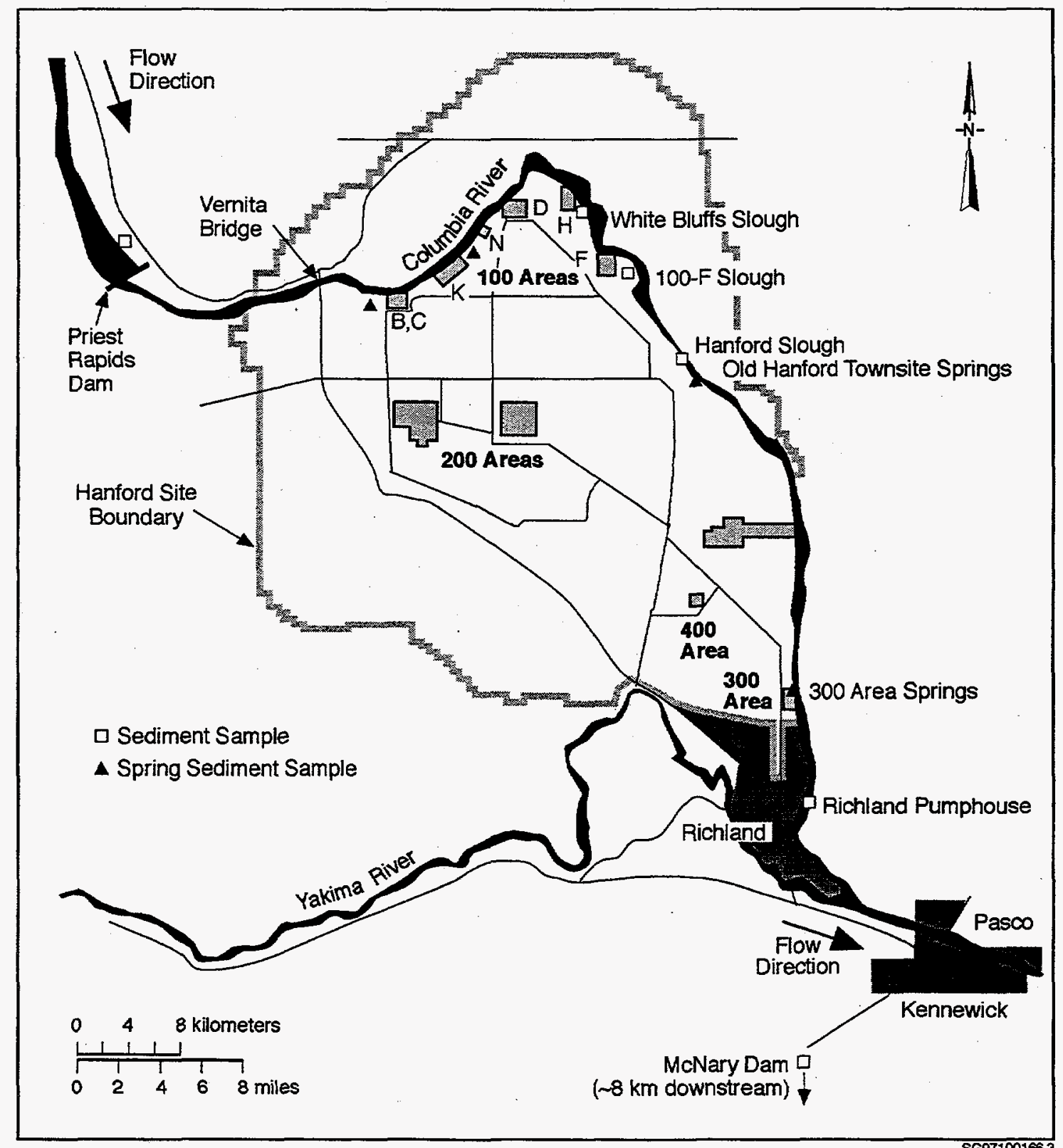

Figure II.A-5. Sediment-Sampling Locations 
In addition to the routine sediment-sampling activities, core samples are collected periodically from the upstream and downstream impoundments to determine the distribution and fate of the contaminants present as a result of past Hanford Site operations. The frequency of this sampling is dependent on the findings of past sampling activities and in consideration of future river and/or downstream impoundment activities.

\section{Sample-Collection Methods}

Because of the depth and swiftness of the river at some of the sediment-sampling locations, samples are collected using a dredge-type mechanical sampler. In some cases, primarily in the shallow-water sloughs along the Hanford Reach, the dredge is used manually to better control the sample depth. Samples are collected according to PNL. MA-580, Rev. 2.

\section{Analytical Methods}

Analytical methods are selected to meet the minimum goal of detecting levels equivalent to a human dose of $1 \mathrm{mrem}$ EDE if that concentration were sustained for a year. An additional goal is to achieve the lower detection levels available using standard state-of-the-art analytical methods. These goals and the analysis methods and detection limits are summarized in the subsection entitiled Laboratory Procedures.

\section{Quality Control Methods}

Sediment surveillance is controlled under the overall project quality assurance and analytical control program, described in the Quality Assurance and Quality Control subsection.

\section{Reporting/Alarm Levels}

Anomalous results are flagged by computer screening of reported data as they are entered into the project database. Levels for reporting to DOE-RL have been established and are listed in the Records Management and Reporting subsection. Reporting levels are equivalent to the concentration that might lead to a dose of 1 mrem EDE to the maximally exposed individual if it were sustained for a year. This reporting level provides early indication of conditions that might eventually require reporting to DOE-HQ as specified by DOE Order 5400.5 .

\section{Exceptions}

No exceptions have been taken to should* statements in DOE/EH-0173T.

\section{Biota and Soil Surveillance}

This subsection details the former tasks of agricultural products, vegetation and soil, and fish and wildlife. Surveillance of these media provides the baseline data to address and evaluate the occurrence of both onsite and offsite radiation contamination. 
A master schedule for all routine sampling is published annually (e.g., PNNL-11464). The resulting analytical data are reviewed individually and collectively, summarized, and published in the annual environmental monitoring report (e.g., PNNL-11472). That report compares the trends in the monitoring data collected over the previous $5 \mathrm{yr}$, and the information is used to reevaluate sample-site selection, media to be sampled, and radionuclides that require monitoring.

The data collected from the biota and soil surveillance activities are maintained in the Hanford Environmental Information System (HEIS), a comprehensive computer database that allows comparisons with previously collected data from the same location or from designated control sites. Maintenance of these data is important as long as accident scenarios indicate the potential for significant offsite contamination.

The biota and soil surveillance activities are outlined below.

- Agricultural products are major contributors to the economy of the Columbia Basin. The Hanford Site is surrounded by large tracts of arable land, and surveillance of agricultural products grown on this land is an important element of surface environmental surveillance. Radioactivity of Hanford Site origin can reach agricultural areas by two pathways: atmospheric dispersion and application of irrigation water from the Columbia River. The Riverview area of Pasco is serviced by the Franklin County Irrigation District and the area north of Richland, designated the Horn Rapids area, is serviced by the Port of Benton pump station. Both facilities provide irrigation water that is removed from the Columbia River immediately downstream of the Hanford Site. Agricultural products are grown in downwind areas around the site perimeter and can be potentially affected by atmospheric deposition.

In most cases, current levels of key radionuclides are at or below analytical detection limits. Assurance that regional agricultural products are not contaminated is important to the public, the region's agribusinesses, and the DOE. Therefore, periodic sampling must be done in a manner and frequency that provide the ability to estimate the contribution from site operations.

- Soils and vegetation at publicly accessible areas near and downwind of the site must be monitored to provide assurance to the DOE and the public that these media are not significantly contaminated by Hanford-originated emissions. Surveillance of soils and vegetation is designed to monitor atmospheric deposition of contaminants at offsite locations not influenced by agriculture and at onsite locations adjacent to potential sources of environmental radioactivity. Atmospheric data and modeling indicate that Hanford Site effluents can be carried offsite and deposited onto the land, where there is then the potential for accumulation. Airborne radioactive materials can be either gaseous or particulate and can originate from operational facilities or from resuspension of contaminated soil by wind.

Soils and vegetation on portions of the Columbia River shoreline bordering the Hanford Site are also monitored because they may be exposed to contaminants present in Hanford Site groundwater. Data collected from these media samples are used to maintain continuity in the environmental database in support of any possible emergency response, to compare to historical data, to evaluate trends, and to provide reassurance to the public that Hanford Site effluents do not pose a threat to public health. In many cases, there is little difference between onsite and offsite concentrations at upwind or downwind locations; however, some samples collected near onsite operational areas may have slightly elevated concentrations. 
- Fish and wildlife on and off the site are valued natural and recreational resources. Fish in the Columbia River and game that cross the river or found on islands in the Hanford Reach may be harvested by the public for consumption. It is important, therefore, that fish and wildlife be sampled to document levels of radioactivity in the edible tissues. Hanford Site fish and wildlife may be exposed to radioactive materials from a number of sources. Fish and other aquatic life may be exposed to low levels of radionuclides present in Hanford Site groundwater entering the Columbia River via shoreline springs (i.e., 100-N Area, Old Hanford Townsite, and 300 Area). Exposure to Hanford Site effluents, unplanned releases, and releases from cleanup activities may also lead to low-level contamination of edible tissues.

A large inventory of radioactive waste is found in the $100,200,300$, and 600 Areas, and there is a potential at some of these sites for biointrusion. The collection of species with small home ranges adjacent to operating areas assists in the verification of facility controls. Most waste ponds onsite have been decommissioned and no longer provide a significant habitat for ducks.

Because of the potential for exposure to contaminants and the offsite migration of some animals, continued annual surveillance is considered necessary to provide reassurance to the hunting and fishing public.

Background samples are collected from distant locations, so that the contribution of Hanford-related radionuclides in wildlife tissues can be determined.

\section{Objectives}

The objectives of the biota and soil surveillance activities are the following:

- verify that doses (through the agricultural products pathway and consumption of edible fish and wildlife) caused by Hanford Site operations remain low and quantifiable through periodic sampling as required by $\mathrm{DOE} / \mathrm{EH}-0173 \mathrm{~T}$

- provide assurance to producers and consumers of agricultural products that the degree of contamination caused by site operations is known and documented in the annual Hanford Site environmental report (e.g., PNNL-11472) and special reports as required

- provide baseline data to quantify any incremental effects of unexpected releases of radionuclides and long-term buildup of radionuclides in biota and soil

- monitor the buildup and inventory of long-lived radionuclides onsite and offsite from deposition of aqueous and airborne releases

- monitor contaminated, or potentially contaminated, areas along the Columbia River shoreline

- provide assurance to the public that the degree of contamination from Hanford Site operations is known and quantified

- evaluate radionuclides in wildlife near operational areas as indicators of biointrusion or inadvertent exposure. 


\section{Plan Rationale and Criteria}

The surveillance criteria for biota and soil are based on should* statements found in DOE/EH-0173T. Pathway analyses indicate that effluents of Hanford origin can reach agricultural products through atmospheric deposition at downwind locations and through irrigation with contaminated Columbia River water. Specific agricultural pathways target a variety of local, representative products identified in $\mathrm{DOE} / \mathrm{EH}-0173 \mathrm{~T}$ and emphasize the concern for public assurance.

Soil and vegetation sampling supports air-monitoring efforts to document fugitive radioactive effluents that settle on the ground. Additionally, special sampling is conducted as needed to address sitecleanup actions, decommissioning, and transfer of property to other federal, state, or local agencies. This approach is consistent with guidance given in DOE/EH-0173T.

Vegetation sampling has been reduced in recent years because environmental concentrations of routinely monitored radionuclides have fallen below detection limits. Consequently, monitoring has been focused on those onsite locations that have indicated potentially elevated concentrations, on perimeter downwind locations, and on an upwind location. Special onsite vegetation sampling will emphasize sample collection along the Columbia River shoreline, aquatic vegetation in the river, and selected terrestrial location sites associated with cleanup activities.

Fish and wildlife sampling is based on the potential for consumption by hunters or fishers, the likelihood of exposure, and the possibility of accumulation of radionuclides by fish and wildlife. The species of fish and wildlife selected for sampling are found in sufficient abundance that sampling will not affect population stability. Species that may possibly be consumed as harvestable fish or wildlife are preferred; however, consideration is also given to species that have a high potential for exposure to site effluents or that may intrude into waste sites. Consideration is also given to species that may be specifically consumed by ethnic groups.

Sampling procedures are designed to ensure that sample collection is performed in an unbiased manner. Sampling and data quality objectives are continuously reviewed, as are scheduling or media substitutions depending on availability of farm products and current interests and issues regarding agribusiness and site activities. The data from these samples are also used to support offsite dose estimates based on effluent monitoring.

\section{Media Selection}

Selection of specific media is based on their significance to human dose. Specific agricultural products are selected because they are potentially exposed to atmospheric deposition, irrigation with Columbia River water containing Hanford Site effluents, or naturally contaminated groundwater; consumed by farmers; sold commercially; or are known to contribute to a human dose through a specific pathway. The media that are routinely monitored include the following:

- milk - Whole raw milk is collected from control locations (generally upwind and distant from the Hanford Site) and from dairies closer and downwind of the site.

- farm produce - Surveillance of farm produce involves the collection of 10 samples distributed among fruit (apples, grapes, cherries), vegetables (potatoes), and leafy vegetables. Specific foodstuffs are collected by area (Figure III.A-6), and not all areas yield the same types of produce. 


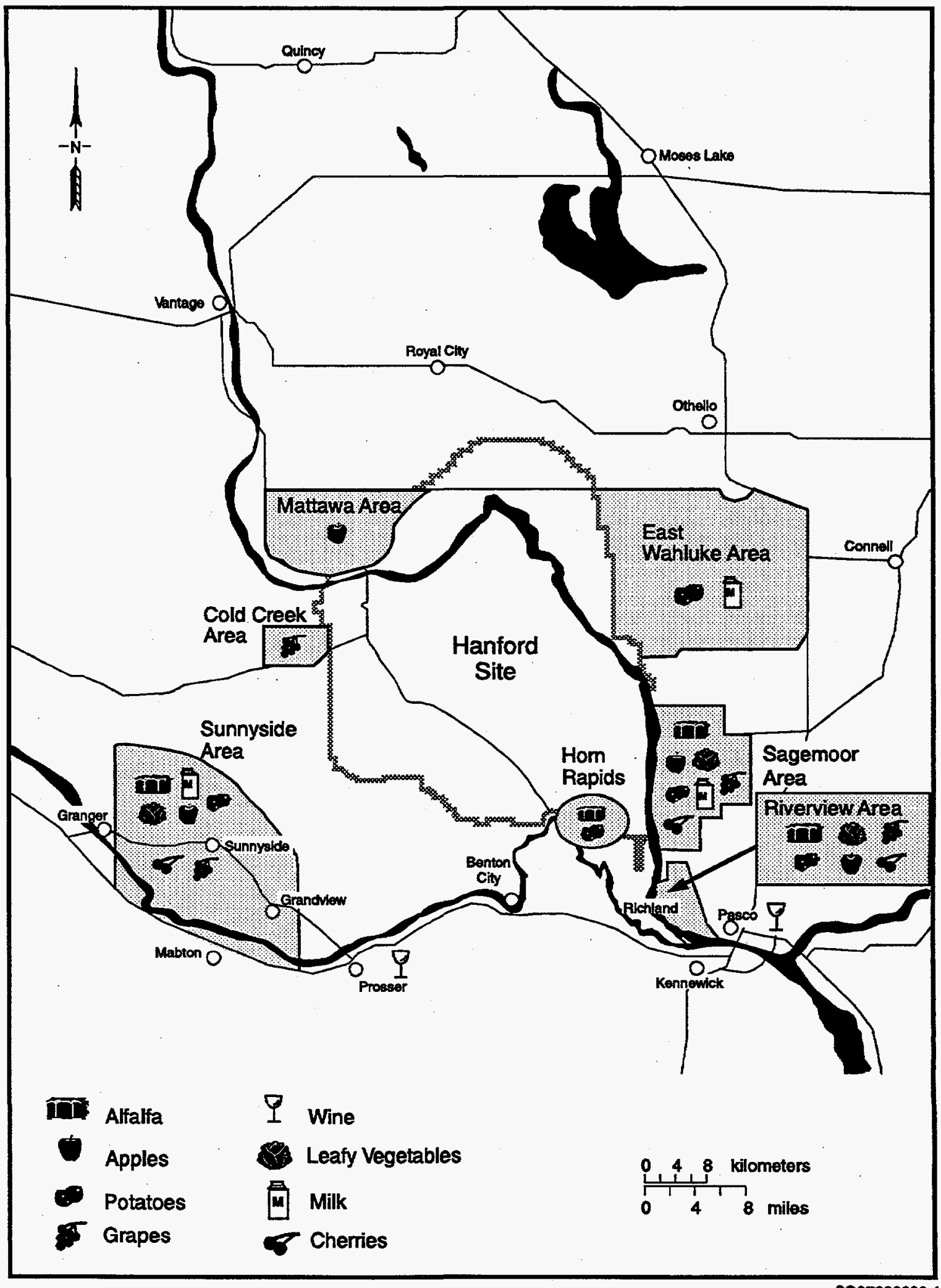

Sa97090080.1

Figure III.A-6. Food- and Farm Product-Sampling Locations 
- alfalfa - Alfalfa samples are collected from one upwind control location and three locations adjacent to the Hanford Site.

- wine - Red and white varieties of wine are collected from upwind and downwind locations. Only wines that have been prepared from grapes grown in the designated sampling areas are analyzed.

- soil and vegetation - Soil samples consist of cores taken to a depth of $2.5 \mathrm{~cm}$. Vegetation is removed before coring, and the sample is sieved before analysis at the analytical laboratory. Routine vegetation samples consist of the prevalent natural plants, usually rabbit brush and sagebrush, at the sampling locations.

- fish - Whitefish have historically been sampled because of their propensity to accumulate radionuclides; however, carp and bass are also sampled. Two sample types are obtained: fillet, representing the edible portion; and offal, the eviscerated remnants including the head, skin, fins, and bones.

- game - The species collected include deer, rabbits, geese, and upland game birds (usually pheasants, but may include chukars). Resident Canada geese are sampled from the Columbia River. Muscle and bone samples are collected.

\section{Analyte Selection}

Radionuclides are selected based on monitored effluent releases, degree to which the radionuclide contributes to the dose associated with the pathway, and public and agribusiness concerns (DOE/ EH-0173T). Cleanup and other site activities that occur in the future may require analyses for specific radionuclides in biota and soil. These will be addressed on a case-by-case basis as they occur. Analytes routinely monitored for in specific media are given in the master sampling schedule (e.g., PNNL-11464).

Agricultural products are analyzed for tritium, ${ }^{90} \mathrm{Sr}$, ${ }^{129} \mathrm{I}$, and gamma emitters (including ${ }^{137} \mathrm{Cs}$ ). These radionuclides are important because of their biological activity: ${ }^{129} \mathrm{I}$ concentrates in the thyroid via the milk pathway, ${ }^{137} \mathrm{Cs}$ is found in muscle, ${ }^{90} \mathrm{Sr}$ accumulates in bone and alfalfa (compared to other crops), and tritium is usually incorporated into liquids within meat or plant material as tritiated water. Principal radionuclides associated with atmospheric fallout are monitored to partition Hanford-related impacts from background and fallout. Generally, fallout radionuclides include ${ }^{90} \mathrm{Sr}$ and ${ }^{137} \mathrm{Cs}$. Last, radionuclides must have a sufficiently long half-life to pose a realistic hazard by the food-chain pathway.

Soil samples are analyzed for the radionuclides common to Hanford Site operations: gamma emitters, ${ }^{90} \mathrm{Sr},{ }^{235} \mathrm{U},{ }^{238} \mathrm{U},{ }^{239,240} \mathrm{Pu}$, and, for selected samples, ${ }^{241} \mathrm{Am}$. Vegetation samples are analyzed for gamma emitters, uranium, ${ }^{90} \mathrm{Sr}$, and ${ }^{239,240} \mathrm{Pu}$. These radionuclides are selected because they persist in the environment, given their long half-lives, and because they are indicative of past site operations.

Fish and wildlife samples are analyzed for ${ }^{90} \mathrm{Sr}$ and ${ }^{137} \mathrm{Cs}$. Gamma spectrometry, which is used to measure ${ }^{137} \mathrm{Cs}$, also measures ${ }^{7} \mathrm{Be},{ }^{40} \mathrm{~K},{ }^{60} \mathrm{Co},{ }^{125} \mathrm{Sb},{ }^{152} \mathrm{Eu},{ }^{154} \mathrm{Eu},{ }^{155} \mathrm{Eu}$, and ${ }^{134} \mathrm{Cs}$. Radionuclide concentrations in wildlife during the past $10 \mathrm{yr}$ have indicated little need to conduct routine analyses for other radionuclides.

\section{Sampling Frequency}

Agricultural products are collected during the harvest season. Sampling locations that represent the potential for the highest environmental dose from Hanford Site effluents are sampled more frequently 
than others. Specific fruits and vegetables are sampled in alternating years or on a 3-yr cycle as indicated in the master sampling schedule (e.g., PNNL-11464). Approximately 20 milk samples are collected from several locations on a quarterly or semiannual basis.

Soil and vegetation samples have been collected on a 5-yr cycle since 1994, and are scheduled for collection in 1999. The sampling program will be reevaluated/adjusted to reflect current conditions and data quality objectives in 1999. This cycle is adequate to detect long-term trends in environmental radioactivity. This sampling schedule is consistent with DOE/EH-0173T requirements and the change in the site's mission from production to cleanup.

Fish and wildlife are collected on a rotating schedule, as indicated in the master sampling schedule (e.g., PNNL-11464). This schedule exceeds the minimum requirements of DOE/EH-0173T; however, the current level of effort is consistent with meeting DOE concerns for public reassurance relative to contamination levels in fish and game in the region, emphasis on cleanup activities on the site, and recent concerns about contaminants in the Columbia River.

Fish collections have been placed on a 2- to 3-yr rotating schedule, including collections at background locations. Whitefish and carp are collected in alternating years from Hanford Reach locations (in particular, the $100-\mathrm{N}$ to $100-\mathrm{D}$ section of the river) and at background locations every $5 \mathrm{yr}$. The more frequent collection of carp and whitefish is justified because both species are bottom-feeding omnivores and are prone to accumulate radionuclides associated with benthic food chains. Bottom-feeding fish generally accumulate higher levels of contaminants than do species with other feeding preferences. Bass are sampled from the 100-F and Hanford Sloughs every $3 \mathrm{yr}$ because of their popularity with local fishers.

Wildlife samples are collected in alternating years, with rabbits alternating with deer and pheasants alternating with geese. Wildlife populations undergo natural fluctuations, and routinely scheduled species are not always abundant or easily collected. When this occurs, the sampling and data quality objectives are reviewed and scheduling or species substitutions are considered. Offsite control wildlife are collected on a 5-yr schedule. All collections of fish and wildlife are conducted under permit with the State of Washington Department of Wildlife, the U.S. Fish and Wildlife Service, and PNNL's animal care committee, which oversees all PNNL activities dealing with vertebrate animals.

\section{Sampling Location Selection}

Locations are selected to provide samples that are likely to contain the maximum offsite concentrations of radionuclides from Hanford Site-originated atmospheric and liquid effluents (see DOE/ EH-0173T). Control or background locations are upwind of the Hanford Site or are independent of the Hanford Reach and Hanford Site groundwater.

The Riverview area and the Horn Rapids area are sampled for farm products because they are the first agricultural areas located downstream of the Hanford Site that use Columbia River water for irrigation. The remaining agricultural sites are located primarily on the site perimeter in downwind locations (see Figure III.A-6).

Sites for soil and vegetation sampling are located in undisturbed areas to facilitate monitoring of long-term accumulation (Figure III.A-7). Generally, soil and vegetation samples are collected near airand external radiation-sampling locations to facilitate interpretation of results (see DOE/ET-0173T). Sampling locations along the Columbia River shoreline are selected to monitor potential public exposures to contaminated vegetation. Onsite soil- and vegetation-sample locations are selected to provide close-in monitoring of operational areas that can release radioactive materials. 


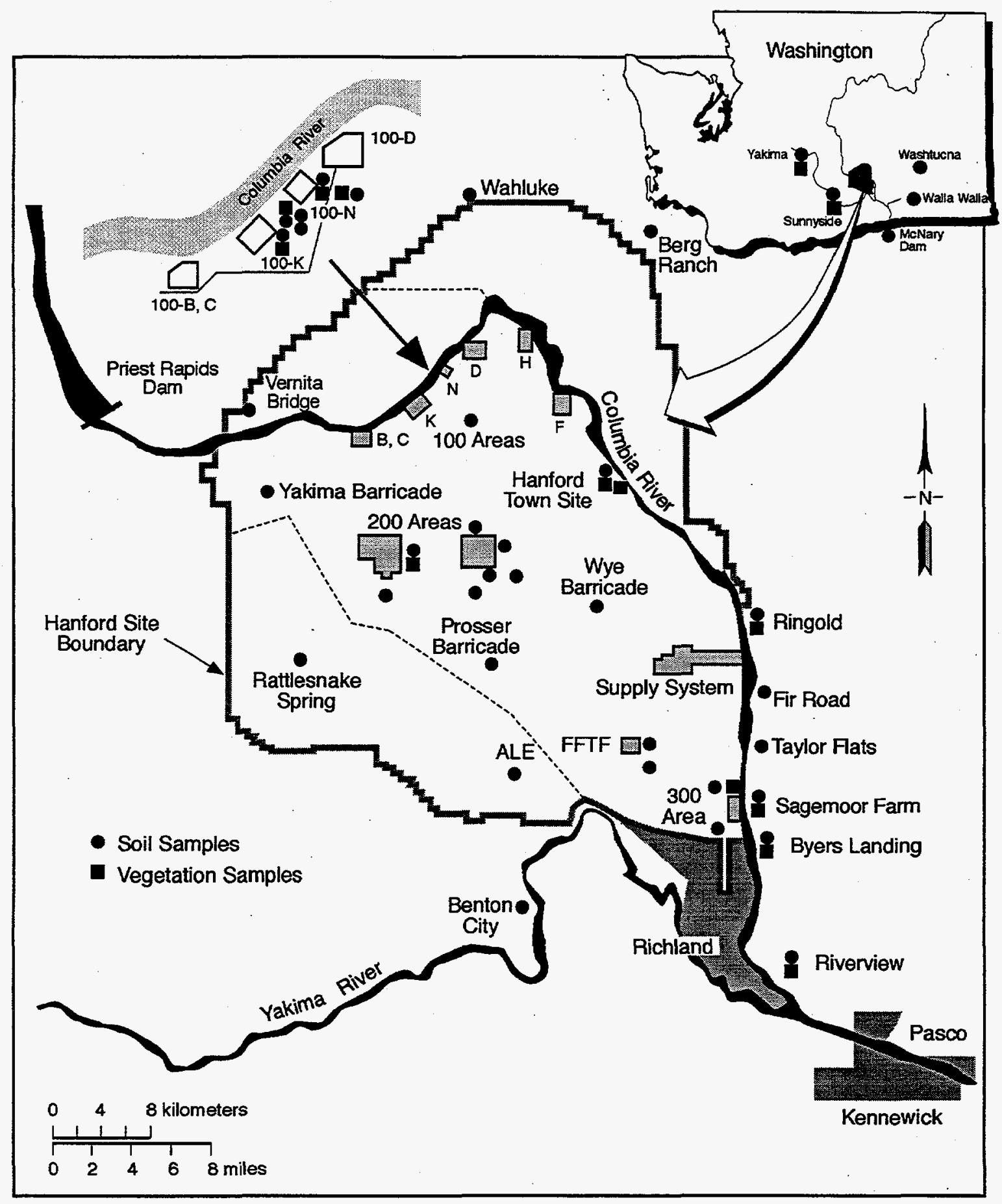

Figure III.A-7. Soil- and Vegetation-Sampling Locations

59412049.8

Samples of fish are collected immediately adjacent to and downstream of locations where potentially contaminated spring water is known to enter the Columbia River (Figure III.A-8). Wildlife are collected from locations with the highest potential exposure to Hanford Site radioactive effluents (e.g., the $100-\mathrm{N}$ Area springs). Special nonroutine analyses are anticipated for elk on the Hanford Site because the population has moved onto the central plateau and toward the Columbia River. 


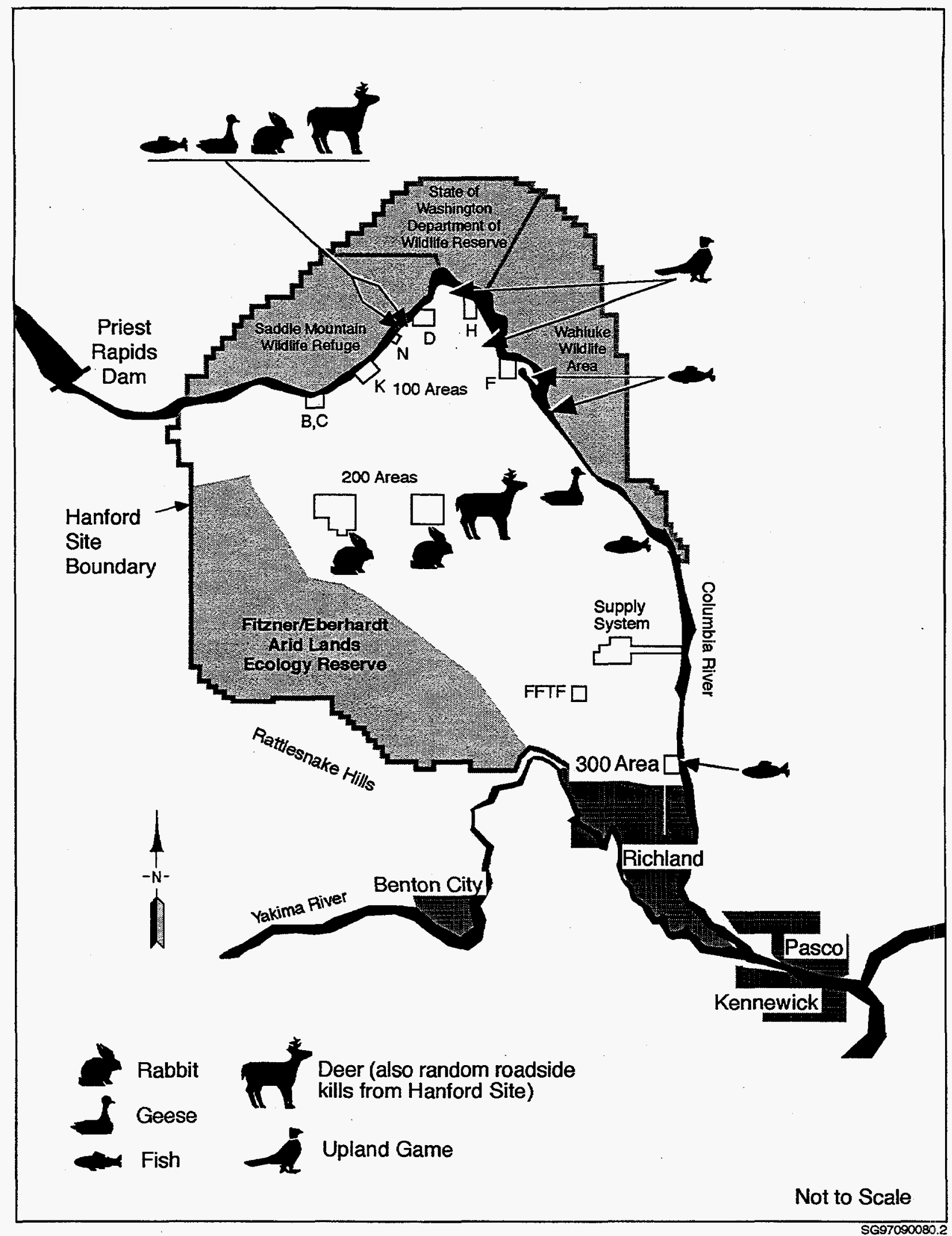

Figure III.A-8. Wildlife-Sampling Locations, Excluding Background Area 
Control samples are collected from areas expected to receive approximately the same contribution of fallout radioactivity as is found on the Hanford Site. For fish, these controls are distant upstream residents that have a low probability of passing over upstream dams. Control sites for game species are distant, generally considered upwind of Hanford (e.g., Boardman, Oregon, for rabbits and remote arid locations for deer).

\section{Sampling or Measurement Methods}

Sampling methods are described in PNL-MA-580, Rev. 2, which also addresses sample preparation. Agricultural products are collected in a manner to ensure that adequate amounts of sample are obtained to meet analytical detection limits. Care is taken to ensure that the produce sample is not contaminated with soil.

Soil is sampled to a depth of $2.5 \mathrm{~cm}$ and a diameter of $10 \mathrm{~cm}$ with a shallow coring device ("cookie cutter") and composited to form one sample from five cores. Vegetation samples consist of the current year's growth collected from shrub species present in proportion to their estimated abundance at the sample site.

Fish and wildlife are collected by trapping, hunting, and several methods of fishing, including rod and reel, electroshocking, and seining. Disposal of animal waste is performed in accordance with state regulatory agency and PNNL waste-management guidance.

\section{Sample-Handling/-Treatment Methods}

Perishable agricultural samples, such as milk, are stored in ice chests when collected and during transport to the analytical laboratory (see PNL-MA-580, Rev. 2). Usually, samples are delivered to the analytical laboratory on the day of collection. If they must be stored before delivery, they are refrigerated or frozen as needed to minimize spoilage.

Soil and vegetation samples are double bagged when collected to minimize the potential for crosscontamination. Some soil samples are taken with a "riffle splitter," producing two homogeneous subsamples that are sent to different analytical laboratories as part of a cooperative sampling program with the State of Washington Department of Health.

Samples of fish and wildlife are processed to obtain bone and edible tissue. Special care is taken to ensure that flesh and organs are not contaminated by the skin or hair or by piercing the gastrointestinal tract when cleaning the animal. Whenever possible, a sample mass adequate to meet the minimum detectable concentration is collected; however, at times, sample masses are less than the required amount and the minimum detectable concentration increases proportionally. Tissue samples must also be kept free of dirt because background levels in the soil can lead to erroneously high values.

\section{Analytical Methods}

Analytical methods are selected to meet the minimum goal of detecting a radionuclide concentration that would yield a dose of 1 mrem EDE if that concentration were sustained in the medium and the medium were consumed for a year. An additional goal is to achieve the lower detection levels available using standard state-of-the-art analytical methods. These goals and the analysis methods are discussed in the subsection entitled Laboratory Procedures. 


\section{Quality Control Methods}

Surveillance of biota and soil is controlled under the overall project quality assurance and analytical control program described in the Quality Assurance and Quality Control subsection. Duplicate samples of selected farm products are sent to the State of Washington Department of Health and/or the U.S. Food and Drug Administration for comparative analysis.

\section{Reporting/Alarm Levels}

Anomalous analytical results are flagged by computer screening as data are entered into the HEIS database. Concentrations requiring DOE-RL notification have been established and are listed in the subsection entitled Records Management and Reporting. Reporting levels are equivalent to the concentration that might lead to a dose of $1 \mathrm{mrem}$ EDE to the maximally exposed individual if it were sustained for a year. For consumable media, this is a function of the concentration in the edible portion of the medium. For soil, it is external exposure, with the exceptions of ${ }^{90} \mathrm{Sr}$ and ${ }^{137} \mathrm{Cs}$. Reporting levels for these radionuclides are nominally equivalent to a dose of $10 \mathrm{mrem}$ if sustained for $1 \mathrm{yr}$ because the large natural variability in such samples makes it impractical to detect a 1-mrem difference. This reporting level provides early indication of conditions that might require reporting to DOE-HQ as required by DOE Order 5400.5 .

\section{Exceptions}

No exceptions have been taken to should* statements in DOE/EH-0173T.

\section{External Radiation Surveillance}

External radiation exposure can be produced by various sources on and around the Hanford Site. The environmental pathways through air and surface water can transport radionuclides from effluent sources (point or diffuse) to locations near the public and other biota. Many of these released radionuclides produce penetrating particles and photons (i.e., beta and gamma radiations) during decay processes in media external to an organism. These media include cloud passage, surface water, soil, sediment, and vegetation. Other actual or potential sources of external radiation on the Hanford Site include radioactive waste-handling, -storage, and -processing activities and radiation-generating facilities and equipment.

Several actual or potential sources could lead to external radiation exposure of the public or onsite biota from radiation or radioactive materials. These sources include waste-process streams, waste sites, diffuse sources, and onsite transport of sources or wastes. Various radiological emergency scenarios may result in significant levels of external radiation in the environment. Because of continuing changes in site operations, and land use, the significance of each of these pathways continues to vary.

Each year, a radiological pathway analysis and exposure assessment is performed. The pathway analysis, based on effluent data, does not address existing and potential external radiation from sources such as contaminated surface sediments, soil, and waste sites. However, background and elevated levels of external radiation have been studied extensively in the Hanford Site environment (PNL-3127, PNL-7124, 
PNL-8789), with detection of measurable increases caused by Hanford Site operations at various onsite locations and on the Hanford Reach of the Columbia River. An aerial survey (EGG 10617-1062) confirmed most of these findings, indicating several onsite locations and locations along the Hanford Reach that have above-background gamma levels. These elevated terrestrial exposure locations are mainly to the south and west of the Columbia River (onsite operational areas) and are generally not accessible to the public for extended periods of time. The elevated radiation locations along the river, islands, and state/federal wildlife land of the Hanford Site are areas with access restrictions; however, the public occasionally occupies these areas for varying lengths of time. The highest exposure rate at a publicly accessible location occurs near the 100-N Area shoreline. At this location, exposure levels are approximately twice the natural terrestrial background for the area. These studies and other data indicate that Hanford operations, in recent history, have not caused detectable increased levels of offsite external radiation.

Generally, it can be expected that slight increases in offsite external exposure rates from current routine releases will be difficult if not impossible to detect above background using cost-effective conventional monitoring (thermoluminescent dosimeters [TLDs], survey meters, etc.).

\section{Objectives}

The objectives of external radiation monitoring are the following:

- obtain external exposure measurements for actual and potential external radiation levels at locations of actual and potential public access to support the verification that doses to the public through all potential pathways from Hanford Site operations remain low relative to standards

- provide confirmatory measurements of actual or potential increases in exposures of the public or biota to radiation or radioactive materials from nuclear operations, waste-process streams, waste sites, diffuse sources, or onsite transport of sources or waste

- obtain preoperational baseline data and environmental data near waste units scheduled for treatment and/or restoration to assess the integrated effects of individual operations

- obtain measurements at the site perimeter and in nearby communities to provide public assurance that the degree of external radiation exposure from site operations is known

- measure onsite and offsite external radiation exposure for emergency response to accidents and provide measurements to assess the environmental effects and doses from unusual releases

- support the evaluation of the effectiveness of Hanford Site effluent controls and models for predicting the concentrations of pollutants in the environment

- conduct surveillance to meet Fast Flux Test Facility technical specifications (HEDL 1981).

\section{Plan Rationale and Criteria}

The criteria for external radiation monitoring consist of those identified as the should ${ }^{*}$ statements in DOE/EH-0173T. Any exceptions to those criteria are identified in the Exceptions discussion below. The level of surveillance and the specific criteria to meet the above objectives are described below. 
The monitoring locations, measurements, methods, and frequencies for meeting external radiation surveillance objectives and criteria are given each year in the sampling schedule published for that year (e.g., PNNL-11464). The rationale and any specific criteria for these selections are discussed below.

\section{Media Selection}

External radiation exposures are measured with consideration for the types and levels of exposure expected from the various pathway transport media and other direct radiation sources. Some of the critical environmental media or sources causing potential external radiation exposure are airborne cloud passage, immersion in surface water, vegetation (i.e., contaminated tumbleweeds), shoreline sediments, and facilities at waste-handling sites.

Most of the types of radiation causing external exposures are gamma photons and beta particles. External neutron and alpha particle exposures to the public have negligible potential. Historical data support the approach of designing the measurement methods mainly for photon sources, but pure beta emitters exist in the environment unaccompanied by gamma emitters (e.g., ${ }^{90} \mathrm{Sr}$ ). Exposure levels at publicly accessible locations are typically in a range from the natural background level to possibly two to three times greater than the natural terrestrial background.

\section{Analyte Selection}

Whole-body and skin doses from external radiation fields caused by gamma (i.e., ${ }^{137} \mathrm{Cs}$ ) and "hard" beta emitters (i.e., ${ }^{90} \mathrm{Sr}$ ) are estimated using a variety of methods.

\section{Sampling and Analysis Frequency}

Sampling frequencies are determined based on the potential for detecting elevated external radiation levels and for public exposure. Equipment limitations can be important, as in the case of the widely used TLD. The minimum detectable integrated exposure of the currently used system is $\sim 5 \mathrm{mR}$, and exposure times that produce at least 15 to $20 \mathrm{mR}$ are recommended for the desirable " 2 sigma" ( $95 \%$ confidence level) values. The potential for detecting external radiation levels caused by current onsite operations is insignificant at most offsite locations, as opposed to onsite locations that have variable and greater potential. Sampling frequencies for onsite surveys and TLDs require adjustments that reflect changes such as potential for loss of control of radiation and modifications in operations or transportation of radiation sources. If intermittent or sporadic operations have significant potential for elevating environmental exposures, survey frequencies are adjusted. Established communication channels with Hanford Site contractors are used to acquire current operational information.

The exchange frequency for all TLDs is quarterly because approximately this much exposure time is needed to generate statistically confident results above the limit of detection. Frequencies for TLDs in significantly elevated exposure areas such as the $100-\mathrm{N}$ Area shoreline were monthly because this exposure period was long enough to provide statistically confident results and because this is an area of significance for detecting potential public exposures. The frequency has been changed to improve the statistical confidence (longer exposures), to reflect the slight decrease in exposure levels along the 100-N Area shoreline, and to make the TLD collection cost efficient. If sampling periods shorter than $1 \mathrm{mo}$ are needed, pressurized ionization chambers or exposure meter measurements are used.

The pressurized ionization chamber measurements are continuously taken at prevailing downwind offsite locations. "Running" average exposure rates are displayed on a liquid crystal display, and 
averages are transferred to a removable data cartridge. The exposure rate data on the cartridge are collected monthly and transferred to a spreadsheet file for evaluation by PNNL staff. The data are plotted and posted at community-operated environmental surveillance stations for public information.

Frequencies for instrument surveys vary and are set to be approximately proportional with the potential for detecting elevated exposure to the public. Some onsite surveys, such as all waste-site, road, and rail surveys, are performed by Waste Management Federal Services of Hanford, Inc. and will be considered in establishing frequencies. Shoreline surveys are performed quarterly to coincide with TLD exchange dates for efficiency.

\section{Sampling Location Selection}

External radiation sampling locations are selected to accomplish the surveillance objectives. Several sources of information are used to help determine the potential for detecting increased exposures to the public. Some important factors that influence the determination of sampling locations are the radiation source characteristics, meteorology, geography, hydrology and sedimentation, population distribution, and recreational activities or lifestyles.

Although it appears that for public dose assessment there is little need to perform distant offsite external radiation monitoring for effects from airborne routine effluents or diffuse sources, selected sampling sites are maintained and concentrated around the local communities. There is a continual need for emergency preparedness dosimetry, confirmation of effluent controls, dose modeling, public assurance, and background monitoring. The fulfillment of these needs requires placement in strategic offsite locations that are generally upwind for the background location(s) and in population centers weighted toward prevailing wind directions (BNWL-SA-4534, BNWL-SA-4676). Because of the size of the Hanford Site, maximum predicted concentrations from airborne effluents are typically onsite, and sampling at these locations should continue even though the data do not indicate public exposures.

The effects of the river-transport pathway on external radiation levels have been studied because of the significant amount of radionuclides released into the Columbia River from past operations (PNL-3127). Liquid effluents from waste-water treatment, groundwater, and contaminated springs have generally continued to decrease, causing lower levels of external exposure-producing radionuclides in the Columbia River. At the same time, most of the elevated exposure areas on the shoreline and islands from radionuclides that have accumulated in the sediment have decreased because of physical decay. Although significant external exposure potential at accessible locations along the river appears to be decreasing, it is assumed that elevated radiation levels to which the public could be exposed will be detectable for many years. Because of extensive river usage by local inhabitants, exposure monitoring will continue with emphasis on characterizing potential radiation fields that may expose the public. The $100-\mathrm{N}$ Area shoreline has the greatest potential for the detection of increased external exposure levels from onsite operations. A technical consideration in selecting associated sampling locations along the river is the fact that the shoreline levels change significantly with water-level fluctuations. This creates a variable when estimating a dose, based on stationary sampling points, to someone standing at the shoreline. This is addressed by intermittent exposure surveys (survey meter, pressurized ionization chamber, etc.) during seasons of recreational use. Selecting sampling locations is coordinated with water- and sedimentsampling locations for data comparability and support to the extent possible.

Before starting a new TLD sampling location, an initial survey is performed and documented to determine the natural radiation levels. Gamma spectroscopy, pressurized ionization chamber measurements, micro-rem meters, and/or soil-sample analyses are considered in initial survey characterizations. 
A 1989 study (PNL-7124) confirmed the importance of characterizing the radionuclides contributing external dose at sample locations. That study determined that naturally occurring higher concentrations

of ${ }^{40} \mathrm{~K}$ and thorium caused some perimeter TLD results to be consistently higher than typical onsite or offsite samples.

Sampling locations for pressurized ionization chamber systems are not near large structures, in valleys, near atypical geologic strata, or at an unrepresentative altitude unless it is determined that such characteristics do not jeopardize the surveillance objective for that location.

\section{Sampling or Measurement Methods Selection}

Ambient whole-body external radiological dose integrations are currently performed using the Harshaw 8807 environmental dosimeter, consisting of two lithium fluoride (TLD-700) chips and two calcium fluoride dysprosium (TLD-200) chips (reserved for emergencies). The TLD-700 chips are preferred over others because of their relatively energy-independent response, tissue-equivalent atomic: mass, and minimal fade when deployed for extended periods.

The pressurized ionization chamber system is used at various offsite and onsite locations to accurately measure instantaneous whole-body exposure rates from gamma photons or X-rays with energies greater than $70 \mathrm{keV}$. The system has computer memory capability to record average exposure rates over varying lengths of time and to integrate total exposures. The manufacturer-published accuracy for the system is $\pm 5 \%$ at background levels, with a range extending to $100 \mathrm{mR} / \mathrm{h}$.

Routine external exposure-rate surveys along the Columbia River are performed using micro-rem meters. The Bicron micro-rem meter detector utilizes a tissue-equivalent organic scintillator to measure dose rate. The energy response of the micro-rem meter is approximately flat for photon energies above $40 \mathrm{keV}$.

Routine contamination surveys by hand-held instruments are performed using the Geiger-Müller survey meter. Geiger-Müller meters are used for measuring surface contamination levels for beta or gamma emitters; results are reported in counts per minute and used to interpret compliance with regulatory limits. Although alpha-emitting radionuclides typically do not pose significant external radiation problems, the use of portable alpha survey equipment, such as an alpha scintillation probe/meter, is required when there is a concern about isolated alpha-emitter contamination.

\section{Sample-Handling/-Treatment Methods}

The TLDs are collected in a manner to ensure accurate exposures by appropriately shielding them in lead containers before and after deployment. The TLDs are handled in transport with consideration for keeping them unexposed to significant external radiation fields that would generate false-positive data. Comments describing any unusual handling of TLDs or any findings that may affect TLD results are recorded on the Environmental Monitoring Trip Log. Sample-collection and -handling procedures are documented in PNL-MA-580, Rev. 2.

\section{Analytical Methods}

Ambient dose is measured at TLD stations using one Harshaw 8807 environmental dosimeter, consisting of two lithium fluoride (TLD-700) chips and two calcium fluoride dysprosium (TLD-200) chips. The Harshaw card is contained in a sealed plastic holder. This dosimeter provides both shallow- and 
deep-dose measurement capability. The TLD is mounted on a plastic pipe attached to a metal post at $\sim 1 \mathrm{~m}$ above the ground. The two TLD-700 chips at each site are read and averaged to determine the routine exposure (or dose). The two TLD-200 chips are read and reported only as necessary following emergency conditions.

Harshaw series 8800 automated reader systems are used to process all Hanford Site environmental dosimeters. A specific time-temperature profile processing protocol is followed for environmental dosimeters. Only the dosimetric portions of the respective TLD-200 and TLD-700 glow curves are used to calculate dose.

\section{Quality Control Methods}

The most important quality control features in this task are the calibration, maintenance, and audits of the TLD reading/recording system; calibration and maintenance of survey instruments; anomalous data-tracking system; Radiation Protection Technologist training; and procedures and records maintenance. The quality control for TLDs is established pursuant to the Standards-Based Management System (PNNL 1997). Intercomparison studies have been conducted to determine and document TLD processing performance. Some stations are collocated with the State of Washington Department of Health TLDs for intercomparison of results. Survey instruments are calibrated to American National Standards Institute N42.17, using radiation sources and standards traceable to the National Institute of Standards and Technology. Check source tests of detection equipment are routinely performed before, during, and after (when required) surveys. The pressurized ionization chamber system is returned to the factory for calibration and maintenance periodically. The anomalous data-tracking system in the environmental database is used to perform initial screening of TLD data (discussed in the subsection entitled Quality Assurance and Quality Control).

\section{Reporting/Alarm Levels}

Anomalous TLD results are flagged by computer screening of reported data as they are entered into the project database. Investigation into an anomalous result includes, as necessary, verification of the quality of the result (sampling and analytical aspects), questioning the operators of facilities near the location with anomalous results about unusual situations, reviewing nearby air-sampling results, and possibly following up with immediate portable instrument measurements and/or gamma spectroscopy. Reporting levels for TLDs and pressurized ionization chambers have not been set because these instruments are not capable of reliably detecting an annual incremental dose of $1 \mathrm{mrem}$ EDE above background, and measurements of environmental media are more capable of detecting events that could lead to a 1-mrem EDE incremental external dose.

\section{Exceptions}

Neutron dose detection currently is not of concern in environmental measurements because no significant potential sources for public exposure have been identified. Facility construction, security, and distances to public access points eliminate the potential for any public exposure to significant neutron fields.

Potential submersion skin doses to members of the public are estimated from effluent data and are included in dose calculations for the EDE to members of the public. Although TLDs do perform some beta detection, potential skin dose to the public is currently not considered significant and is not reported in TLD results. 
Onsite or offsite continuous gamma spectroscopy has not been used to detect environmental exposures because the cost has not been justified by current operations and effluent levels. Gamma spectroscopy has been used and is available for the characterization of photon-emitting radionuclides at various onsite and offsite locations.

Shoreline exposure measurement locations are not typically established at key water-sampling locations at the site boundary (along the Columbia River) because concentrations of radionuclides in water are routinely low enough not to cause any significant external exposure. If water sampling is performed in areas where the concentration levels are suspected to be high enough to cause external exposures, exposure measurements are made.

\section{Dose Assessment Methods}

The radiological dose that the public potentially receives during a calendar year from Hanford Site operations is calculated in terms of the "effective dose equivalent" (EDE). These dose quantities are given in units of millirem (mrem) (millisievert [mSv]) for individuals and in units of person-rem (person-Sv) for the collective dose received by the total population within an $80-\mathrm{km}$ radius of the site. These quantities provide a way to uniformly express the radiological dose, regardless of the type or source of radiation or the means by which it is delivered. This subsection describes how the doses are calculated.

Releases of radionuclides from Hanford Site activities are usually too low to be measured in offsite air, drinking water, and food crops. Therefore, in most cases, the dose calculations are based on measurements made at the point of release (stacks and effluent streams), and environmental concentrations are estimated from these effluent measurements by environmental transport models.

The transport of radionuclides from the release source to the point of exposure is predicted by empirical models of exposure pathways. These models calculate concentrations of radionuclides in air, water, and food. Radionuclides taken into the body by inhalation or ingestion may be distributed among different organs and retained for various times. In addition, long-lived radionuclides deposited on the ground become possible sources for long-term external exposure and uptake by agricultural products. Dietary and exposure parameters are applied to calculate radionuclide intakes and radiological doses to the public. Standardized computer programs are used to perform the calculations. These programs contain internally consistent mathematical models that use site-specific dispersion and uptake parameters. These programs are incorporated in a master code, GENII (PNL-6584), which employs the dosimetry methodology described in reports by the International Commission on Radiological Protection(1979a, 1979b, $1980,1981 \mathrm{a}, 1981 \mathrm{~b}, 1982 \mathrm{a}, 1982 \mathrm{~b}, 1988)$. The assumptions and input data used in these calculations are described below.

\section{Types of Dose Calculations Performed}

Calculations of radiological doses to the public from radionuclides released into the environment are performed to demonstrate compliance with applicable standards and regulations. 
The DOE requires that estimates of radiation exposure to the general public be in EDE terms. The EDE represents the total risk of potential health effects from radiation exposure. The adoption and use of the EDE were previously recommended by the International Commission on Radiological Protection (1977). In addition to implementing the EDE requirement for offsite population dose calculations, DOE has also adopted the biokinetic models and metabolic parameters for radionuclides given by the International Commission on Radiological Protection in 1977 for estimating radiological dose. As in the past, when concentrations of radionuclides in the environment are too low to measure, DOE specifies that the doses are to be calculated from effluent data using environmental transport and dosimetry models.

The calculation of the EDE takes into account the long-term (50-yr) internal exposure from radionuclides taken into the body during the current year. The EDE is the sum of individual committed (50-yr) organ doses multiplied by weighting factors that represent the proportion of the total health-effect risk that each organ would receive from uniform irradiation of the whole body. Internal organs may also be irradiated from external sources. The external exposure received during the current year is added to the committed internal dose to obtain the total EDE. The EDE is frequently expressed in rem (or millirem), with the corresponding value in sievert (or millisievert) in parentheses. The numerous transfer factors used for pathway and dose calculations have been documented in GENII (PNL-6584) and in PNL-3777 Rev. 2.

The following types of radiological doses are estimated:

- "boundary" dose rate (millirem per hour and millirem per year) - The external radiological dose rates during the year in areas accessible by the general public are determined from measurements obtained near operating facilities.

- "maximally exposed individual" dose (millirem) - The maximally exposed individual is a hypothetical person living at a particular location who has a postulated lifestyle conducive to receiving higher radiological doses than other members of the public would be likely to receive. All potentially significant exposure pathways to this hypothetical individual are considered, including the following:

- inhalation of airborne radionuclides

- submersion in airborne radionuclides

- ingestion of foodstuffs contaminated by radionuclides deposited on vegetation and the ground by both airborne deposition and irrigation water drawn from the Columbia River downstream of Hanford Site discharges

- exposure to ground contaminated by both airborne deposition and irrigation water

- ingestion of fish taken from the Hanford Reach of the Columbia River

- recreation along the Hanford Reach of the Columbia River, including boating, swimming, and shoreline activities.

- 80-km population doses (person-rem) - Regulatory limits have not been established for population doses. However, evaluation of the collective population doses to all residents within an $80-\mathrm{km}$ radius of the Hanford Site is required by DOE Order 5400.5 . The $80-\mathrm{km}$ population dose represents the summed products of the individual doses for the number of individuals involved for all potential exposure pathways. 
The pathways assigned to the maximally exposed individual are assumed to be applicable to the offsite population. Consideration is given, however, to the fraction of the offsite population actually affected by each pathway. The exposure pathways for the population are as follows:

- drinking water - The Cities of Richland and Pasco obtain their municipal water directly and Kennewick indirectly from the Columbia River downstream of the Hanford Site. A total population of $\sim 70,000$ in the three cities drinks water derived from the Columbia River.

- irrigated food - Columbia River water is withdrawn for irrigation of small vegetable gardens and farms in the Riverview area of Pasco in Franklin County. Enough food is grown in this district to feed an estimated 2,000 people. Commercial crops are also irrigated by Columbia River water in the Horn Rapids area of Benton County.

- river recreation - These activities include swimming, boating, and shoreline recreation. An estimated 125,000 people who reside within $80 \mathrm{~km}$ of the Hanford Site are assumed to be affected by these pathways.

- fish consumption - Population doses from the consumption of fish obtained locally from the Columbia River were calculated from an estimated total annual catch of $15,000 \mathrm{~kg} / \mathrm{yr}$ (without reference to a specified human group of consumers).

\section{Data}

The data that are needed to perform dose calculations based on measured effluent releases include information on initial transport through the atmosphere or river, transfer or accumulation in terrestrial and aquatic pathways, and public exposure. By comparison, radiological dose calculations based on measured concentrations of radionuclides in food require data describing only dietary and recreational activities and exposure times. These data are discussed in the following sections.

\section{Population Distribution and Atmospheric Dispersion}

Geographic distributions of the population residing within an $80-\mathrm{km}$ radius of the four Hanford Site operating areas are based on 1990 Bureau of the Census data (PNL-7803). These data influence the population dose by providing estimates of the number of people exposed to radioactive effluents and their proximity to the points of release.

Atmospheric dispersion data are recalculated each year and are given in the annual Hanford Site environmental data report for that calendar year (e.g., PNNL-11473). These data describe the transport and dilution of airborne radioactive material, which influences the amounts of radionuclides being transported through the air to specific locations.

\section{Terrestrial and Aquatic Pathways}

Important parameters affecting the movement of radionuclides within potential exposure pathways, such as irrigation rates, growing periods, and holdup periods, are provided in the annual environmental report (e.g., PNNL-11472). Certain parameters are specific to the lifestyles of either "maximally exposed" or "average" individuals. 


\section{Public Exposure}

The potential offsite radiological dose is related to the extent of external exposure to or intake of radionuclides released from Hanford Site operations. Parameters describing the diet, residency, and river recreation assumed for "maximally exposed" and "average" individuals are tabulated in the annual environmental report (e.g., PNNL-11472).

\section{Dose Calculation Documentation}

The Hanford Environmental Dose Overview Panel has the responsibility for defining standard, documented computer codes and input parameters to be used for radiological dose calculations for the public near the Hanford Site. Only those procedures, models, and parameters previously defined by the Panel are used to calculate the radiological doses (PNL-3777 Rev. 2). The calculations are then reviewed by the Panel. Summaries of dose calculation documentation for this report are shown in Tables D.5 through D.9 in PNNL-11472 and Tables Dose.1 through Dose.8 in PNNL-11473.

\section{Exceptions}

No exceptions have been taken to should* statements in DOE/EH-0173T.

\section{Dosimetry Coordination}

Dosimetry coordination is an ongoing activity that was initiated in 1975 to support DOE in developing and implementing methods for health and environmental risk assessment. Radiation dose and chemical exposure evaluations are required by DOE to be performed whenever potential environmental exposures exist. These evaluations are typically performed by the individual Hanford Site contractors for a variety of purposes. As directed by DOE, the approach used in risk evaluations and the presentation of the results must be technically consistent across the Hanford Site and in accordance with applicable regulations and DOE Orders.

Dosimetry coordination supports DOE by assessing regulatory requirements, recommending methods for implementing those requirements, and in providing an overview function to ensure that the requirements are met in a technically defensible and consistent manner across the site. Support to develop or maintain software, databases, and other methods used to assess environmental risks is provided. In addition, special projects are undertaken at the request of DOE to aid in resolving risk-related issues or assessing impacts of activities that take place at the site. The major activities are described below.

\section{Hanford Environmental Dose Overview Panel}

Administrative and technical support is provided to the Hanford Environmental Dose Overview Panel, which is comprised of representatives from Hanford Site contractors. The Panel strives to ensure that all environmental and health-risk assessments performed are conducted in a technically defensible 
and consistent manner. The Panel serves as the technical representative for DOE-RL in matters related to environmental and health-risk assessments for operations and facilities on the site.

The purposes of the Panel are the following:

- ensure that appropriate methods (as required by DOE or other regulatory agencies) are used for radiological and nonradiological risk assessments

- ensure that all environmental and health-risk assessments are technically consistent

- foster communication among the contractors regarding environmental and health-risk assessments.

The Panel normally meets quarterly and conducts other activities through working groups that meet as needed to resolve specific issues that arise during onsite risk-assessment activities. The working groups consist of Panel members and other onsite experts, as needed, to address the topics under consideration.

The Panel also supports a group of contractor staff members who serve as Panel-approved reviewers. The reviewers (who are not restricted to Panel members) are called on to review assessments by staff members who perform radiation-dose and chemical-exposure calculations with the use of computer codes or other methods. The reviewers ensure that appropriate methods, assumptions, and associated parameters were utilized in the calculations. Current recommendations approved by the Panel are documented in PNL-3777 Rev. 2. That document is revised periodically to reflect Panel-approved changes in methods and data used for risk assessments at the Hanford Site.

\section{Support for Software, Databases, and Other Risk-Assessment Methods}

This task is designed to provide an up-to-date, technically peer-reviewed, documented set of computer codes for calculating potential radiation doses resulting from radionuclides in the environment. Staff assigned to this task are responsible for maintaining and upgrading the environmental dosimetry codes and databases that are used to assess routine and accidental releases of radionuclides to the environment from Hanford Site facilities and operations. Master copies of the computer codes and libraries are maintained in protected storage with access on a use-only basis. This includes the master files for the GENII software system (PNL-6584) and the Panel-approved version of the CAP-88 code (EPA-402-B-92-001), an updated version of AIRDOS-EPA that is mandated by the EPA for use in some types of radiation dose calculations.

This task supported the production of the GENII software system, which represents the currentgeneration environmental dosimetry code developed for use at the Hanford Site. Distribution of the GENII software to Hanford Site users is provided on request, and a list of the current Hanford Site users is maintained. The code is also distributed to offsite users by the Radiation Safety Information Computational Center in Oak Ridge, Tennessee. The task logs all problem reports that are received from any GENII user and also provides information in the form of summary presentations to organizations or educational institutions regarding risk analysis methods used at the Hanford Site.

The GENII software package has been in use since 1988 , and items that need updating in the code continue to be identified. As part of recent recommendations from national and international radiation. 
protection organizations, the dosimetry models currently in use have been updated, and the revised models are expected to become part of the regulatory framework in the future. In anticipation of new regulatory requirements and to incorporate the results of other recent research in the field of environmental transport and effects of hazardous materials, cooperation is maintained with projects funded by other federal agencies to upgrade the GENII software package. Input from the Panel is critical to ensuring that the code upgrade meets the current needs of onsite users and that it implements models and assumptions required by regulatory standards.

\section{Regulatory Review}

It is important for the effective functioning of the Panel that the staff maintain their knowledge of current DOE Orders and other regulations published in the Federal Register. DOE Orders and other regulations that relate to the need for human health and environmental risk assessments are the focus of the regulatory review. The DOE Orders and other regulations, as well as DOE-HQ and DOE-RL guidance on human health protection, are used to help outline the necessary modifications to risk-assessment methods used at the Hanford Site.

\section{Special Projects}

Issues are routinely identified by DOE-RL or the Panel that may impact the data or methods used for Hanford Site risk assessments. These issues may be technical or regulatory in nature and are investigated by the project at the request of DOE or other onsite contractors.

\section{Quality Assurance}

Quality assurance is established and implemented through the Standards-Based Management System (PNNL 1997).

Independent surveillances and audits may be conducted by PNNL to ensure compliance.

\section{Exceptions}

No exceptions have been taken to should* statements in DOE/EH-0173T.

\section{Data Management, Analysis, and Statistical Treatment}

Described herein are the objectives for management, analysis, and statistical treatment of surface environmental surveillance data. These objectives are primarily achieved through the use of HEIS. HEIS provides computer-based access to Hanford Site environmental sample data and is used to manage the data generated by the ongoing sampling efforts conducted on and around the Hanford Site. 


\section{Objectives}

Good data management, data analysis, and statistical treatment practices are essential for the production of quality results. The objectives for analyzing environmental surveillance data are the following:

- manage data in a manner that ensures their timely collection, analysis, reporting, and validation in accordance with the master sampling schedule (e.g., PNNL-11464) and the traceability of results from scheduling to archiving in the environmental database

- estimate constituent-of-concern concentrations at each sampling and/or measurement point for each sampling and/or measurement time and estimate accuracy and precision

- compare the constituent-of-concern concentrations at each sampling and/or measurement point to previous concentrations measured at the same point to recognize changes or inconsistencies in concentration levels

- compare the constituent-of-concern concentrations at each sampling and/or measurement point to reporting limits

- compare the constituent-of-concern concentrations at individual sampling and/or measurement points to those measured at control or other points and evaluate the results of those comparisons.

\section{Data Management Overview}

HEIS is an operational system specifically designed for handling Hanford Site environmental information and data. HEIS is used to effectively manage data gathered during environmental monitoring activities at the Hanford Site. HEIS includes an integrated database and is intended to provide consistent and current information and data to its users; it enables the sharing of data by all Hanford Site personnel. The major components of HEIS are a database and a geographic information system (GIS). HEIS is implemented using current industry standards including a UNIX ${ }^{\mathrm{TM}}$ operating system, an Oracle databasemanagement system, and a structured query language. The HEIS computer system is managed by Bechtel Hanford, Inc.

In accordance with the annual master sampling schedule (e.g., PNNL-11464), a schedule for collecting samples is established in the database at the beginning of each calendar year. Most samples for environmental surveillance are collected on a routine basis. Sample-identification labels and chain-ofcustody forms are generated weekly by the database steward to facilitate sample collection. The database steward also generates laboratory composite sheets that identify individual samples to be combined to form composite samples. Analytical results are provided by the laboratories and reported in either electronic or hard-copy formats and entered into the database either electronically or manually. The database can also be used to produce various status and result reports to assist personnel in the review of data and to ensure the prompt identification of unusual results. Finally, analytical results stored in the database can be retrieved for review or for use in preparing reports (e.g., PNNL-1 1472).

UNIX is a registered trademark of Novell, Inc., San Jose, California. 


\section{Sample Scheduling}

The cognizant PNNL manager and staff revise the calendar year sampling schedule to meet monitoring needs each year. The sampling locations, sample types, sample analyses, and frequencies of collection are identified and documented (e.g., PNNL-11464). In accordance with that schedule, the database steward establishes the scheduling information in the database at the beginning of each calendar year. Based on this information, the database-scheduling program interrogates itself to determine when a sample must be collected. The scheduled dates are automatically recalculated, based on the collection frequency, and are updated in the computer each week as the database steward generates the sample labels and chain-of-custody forms.

When a new sampling event is identified, the appropriate scheduling information is established in the database so that collection and analyses of the sample can occur.

\section{Sample Collection}

Most samples for environmental monitoring are collected on a routine basis. Sample-identification labels and chain-of-custody forms are generated weekly by the database steward to facilitate sample collection. The sample label identifies the task code (i.e., air, water, biota, soil, sediment, TLDs), HEIS sample-identification number, collection date, and analyses required. Once the sample is collected, the sample label is attached to the sample container and the sample is delivered to the analytical laboratory. The chain-of-custody form lists the samples to be collected on a given day and also identifies the task code, HEIS sample-identification number, sampling location, and date of collection. The chain-ofcustody form accompanies the samples to the analytical laboratory, where the samples are relinquished into the custody of laboratory personnel. Laboratory personnel retain one copy of the signed chain-ofcustody form; the other copy is returned to the database steward and becomes a permanent record that verifies sample collection, delivery, and receipt by the analytical laboratory. Sample-collection and -handling procedures are contained in PNL-MA-580, Rev. 2.

Each month, the database steward also generates composite sheets that identify individual samples to be combined to form composite samples. This information is forwarded to the analytical laboratory responsible for compiling the composite samples. On completion of the compositing process, laboratory personnel return the completed composite sheets to the database steward and they become a permanent record in the project files.

\section{Tracking Sample Collection}

The database is capable of tracking samples from the time the sample labels are produced until the sample results are entered into the database. This allows for accountability of both sample collection and sample analysis. When a sample label is generated (in the case of TLDs, when the chain-of-custody is generated), an accountability file is created for each analysis scheduled (i.e., radiochemical or chemical). After the sample is collected, the collection date, as identified on the chain-of-custody form, is entered into the database, satisfying the sample-collection portion of the accountability file.

The date the sample is submitted to the laboratory is also entered into the database. This date activates the sample-analysis-tracking feature in the accountability file (see Tracking Sample Analysis below). 


\section{Reporting of Analytical Data}

Samples are analyzed for the constituents identified on the sample label, which can include radiochemical or chemical analyses. External radiation surveillance also occurs with the collection of TLDs. Results are reported in association with a 2 -sigma overall propagated uncertainty. In the case of radiochemical results, a 2-sigma counting uncertainty is also reported. Data are reported by diskette or hard copy and are entered into the database either electronically or manually.

The minimum required data that are stored in the database include the following:

- HEIS sample-identification number

- sample location

- sample-collection date

- analysis

- result

- result unit

- sample volume

- comments as appropriate.

\section{Data Validation}

As radiochemical and TLD results are entered into the database, several mathematical tests are performed to determine whether the result is within the range of the established limits. The tests and supporting data include the following:

- Test 1: Was the minimum detectable concentration met?

- Test 2: Was the low limit exceeded?

- Test 3: Was the high limit exceeded?

- Statistics A: The maximum, minimum, and mean of the last 10 results of the same type for this sampling location are...

- Statistics B: The maximum, minimum, and mean of results for this same type at all locations for the previous 12 mo are...

As data are collected, the results are compared to previous results to help identify unusual measure-ments that require investigation or further statistical evaluation. If the result is unusual and fails any of the above tests, it is considered an anomaly and a 1-page anomalous data report is generated.

Outliers can represent a true extreme value or can indicate errors in sample collection, preparation, measurement, or equipment malfunctions. On request, the analytical laboratory will perform a data recheck, recount, or reanalysis to assist the task leader in determining the value of a questionable result. Following these investigations, the task leader, with the approval of the project manager, decides how to handle the suspect data. These decisions are documented on the anomalous data report, which becomes a permanent record in the project files. 


\section{Tracking Sample Analysis}

To aid in the tracking of sample analyses, a maximum turnaround for reporting of results is established with the analytical laboratories. This turnaround, coupled with the sample submit date, provides an estimated due date for each analytical test ordered. If no result has been reported by the estimated due date, the database steward can generate a "late results" report. The late results report also indicates results that were reported late. An outstanding result will continue to appear on the late results report until the result is received and the accountability record has been completely satisfied.

\section{Data Retrieval}

One of the primary reasons for using a data-management system is to store data and provide efficient and easy access to the thousands of analytical results recorded each year. The database contains analytical data back to 1971 , which can be retrieved by using Access ${ }^{\circledR}$.

\section{Database Security}

To prevent the loss of data because of fire, power failure, or other causes, HEIS undergoes a complete backup three times a week by the Bechtel Hanford, Inc. computer systems manager. This backup is stored in a locked fireproof safe.

\section{Quality Assurance}

Records of data and other information developed during the operation of the HEIS are controlled and managed in compliance with the requirements in the PNNL quality assurance plan, which conforms to the requirements of DOE Order 5700.6C and 10 CFR 830.120 as interpreted and implemented by the Standards-Based Management System (PNNL 1997). HEIS database integrity is ensured through the use of rules and constraints implemented directly by the database (refer to BHI-EE-09 regarding HEIS software control).

\section{Data Analysis and Statistical Treatment}

Analytical results are reported and recorded with estimates of their uncertainty. Data sets are not truncated and include negative numbers. The database contains the same number of significant figures reported by the analytical laboratories, but summaries and reports may only include the appropriate number of significant figures. Results are reported as less than the estimated quantitative detection limit.

Data contained in the database vary in sample type (i.e., air, water, biota, soil, sediment, TLDs), and any subset of data of a given sample type may or may not fit probability distributions typical of that type for a variety of potential reasons (e.g., sample size, mixed populations). Therefore, routine statistical summaries obtained from the database are normally based on the arithmetic mean or median as measures of central tendency and on the range, standard deviation, and standard error of the mean as measures of dispersion.

Microsoft Access is a registered trademark of Microsoft Corporation, Redmond, Washington. 
Statistical tests to determine differences and effects are based on parametric or nonparametric tests appropriate to the sample sizes, distributions of the particular data sets being tested, and hypothesis being tested.

Tests for precision and accuracy are addressed in the subsection entitled Quality Assurance and Quality Control.

\section{Exceptions}

No exceptions have been taken to should* statements in DOE/EH-0173T.

\section{Laboratory Procedures}

All routine environmental surveillance samples are analyzed according to written analytical proce-dures. These procedures are described in general terms in this subsection and in detail in the Quanterra Environmental Services laboratory procedures manual and in PNNL department-specific procedures manuals. Contractual minimum detectable concentrations and contract-required detection limits for the various matrix/analysis combinations and other analytical information are shown in Table III.A-1 for radiological analytes and in Table III.A-2 for chemical constituents. In practice, actual minimum detectable concentrations and method detection limits have historically been significantly lower for most analyses.

Table III.A-1. Radiological Monitoring Sampling Summary

\begin{tabular}{|c|c|c|c|c|}
\hline Type of Analysis & $\begin{array}{c}\text { Approximate } \\
\text { Sample Size }\end{array}$ & $\begin{array}{c}\text { Nominal } \\
\text { Count } \\
\text { Time }\end{array}$ & $\begin{array}{c}\text { Minimum } \\
\text { Detectable } \\
\text { Concentration }\end{array}$ & $\begin{array}{c}\text { Nominal Analysis } \\
\text { Aliquot Size }\end{array}$ \\
\hline \multicolumn{5}{|l|}{ Air } \\
\hline Gross alpha & $800 \mathrm{~m}^{3}$ & $50 \mathrm{~min}$ & $0.001 \mathrm{pCi} / \mathrm{m}^{3}$ & $800 \mathrm{~m}^{3}$ \\
\hline Gross beta & $800 \mathrm{~m}^{3}$ & $40 \mathrm{~min}$ & $0.003 \mathrm{pCi} / \mathrm{m}^{3}$ & $800 \mathrm{~m}^{3}$ \\
\hline $\mathrm{HTO}^{(\mathrm{a})}$ & $10 \mathrm{~m}^{3}$ & $250 \mathrm{~min}$ & $0.3 \mathrm{pCi} / \mathrm{m}^{3}$ & $5 \mathrm{~m}^{3}$ \\
\hline${ }^{14} \mathrm{C}^{(b)}$ & $40 \mathrm{~m}^{3}$ & $150 \mathrm{~min}$ & $1.0 \mathrm{pCi} / \mathrm{m}^{3}$ & $10 \mathrm{~g}$ of carbon \\
\hline${ }^{85} \mathrm{Kr}^{(\mathrm{b})}$ & $0.5 \mathrm{~m}^{3}$ & $150 \mathrm{~min}$ & $2.0 \mathrm{pCi} / \mathrm{m}^{3}$ & $0.5 \mathrm{~m}^{3}$ \\
\hline${ }^{90} \mathrm{Sr}$ & $20,000 \mathrm{~m}^{3} / \mathrm{station}$ & $100 \mathrm{~min}$ & $0.01 \mathrm{pCi} / \mathrm{m}^{3}$ & 1,500 to $20,000 \mathrm{~m}^{3}$ \\
\hline${ }^{129} \mathrm{I}^{(\mathrm{c})}$ & $1,500 \mathrm{~m}^{3} /$ station & -- & $0.00001 \mathrm{pCi} / \mathrm{m}^{3}$ & $800 \mathrm{~m}^{3}$ \\
\hline${ }^{131} \mathbf{I}$ & $800 \mathrm{~m}^{3}$ & $100 \mathrm{~min}$ & $0.01 \mathrm{pCi} / \mathrm{m}^{3}$ & $800 \mathrm{~m}^{3}$ \\
\hline Gamma scan $\left({ }^{137} \mathrm{Cs}\right)$ & $5,500 \mathrm{~m}^{3} /$ station & $100 \mathrm{~min}$ & $0.01 \mathrm{pCi} / \mathrm{m}^{3}$ & 1,500 to $7,700 \mathrm{~m}^{3}$ \\
\hline $\mathrm{Pu}$ (isotopic) & $20,000 \mathrm{~m}^{3} / \mathrm{station}$ & $1,000 \mathrm{~min}$ & $0.000005 \mathrm{pCi} / \mathrm{m}^{3}$ & 1,500 to $20,000 \mathrm{~m}^{3}$ \\
\hline${ }^{241} \mathrm{Am}^{(\mathrm{b})}$ & $1,500 \mathrm{~m}^{3} /$ station & $200 \mathrm{~min}$ & $0.00005 \mathrm{pCi} / \mathrm{m}^{3}$ & 1,500 to $20,000 \mathrm{~m}^{3}$ \\
\hline
\end{tabular}


Table III.A-1. (contd)

\begin{tabular}{|c|c|c|c|c|}
\hline Type of Analysis & $\begin{array}{c}\text { Approximate } \\
\text { Sample Size }\end{array}$ & $\begin{array}{l}\text { Nominal } \\
\text { Count } \\
\text { Time }\end{array}$ & $\begin{array}{c}\text { Minimum } \\
\text { Detectable } \\
\text { Concentration }\end{array}$ & $\begin{array}{c}\text { Nominal Analysis } \\
\text { Aliquot Size }\end{array}$ \\
\hline (isotopic) & $1,500 \mathrm{~m}^{3} /$ station & $1,000 \mathrm{~min}$ & $0.00005 \mathrm{pCi} / \mathrm{m}^{3}$ & 1,500 to $20,000 \mathrm{~m}^{3}$ \\
\hline
\end{tabular}

River and Surface Water

$\begin{array}{lllll}\text { Gross alpha } & 500 \mathrm{~mL} & 50 \mathrm{~min} & 4.0 \mathrm{pCi} / \mathrm{L} & 200 \mathrm{~mL} \\ \text { Gross beta } & 500 \mathrm{~mL} & 20 \mathrm{~min} & 4.0 \mathrm{pCi} / \mathrm{L} & 200 \mathrm{~mL} \\ { }^{3} \mathrm{H}(10) & 500 \mathrm{~mL} & 600 \mathrm{~min} & 10 \mathrm{pCi} / \mathrm{L} & 150 \mathrm{~mL} \\ { }^{3} \mathrm{H} & 100 \mathrm{~mL} & 250 \mathrm{~min} & 300 \mathrm{pCi} / \mathrm{L} & 10 \mathrm{~mL} \\ { }^{89} \mathrm{Sr}{ }^{(d)} & 10 \mathrm{~L} & 100 \mathrm{~min} & 0.6 \mathrm{pCi} / \mathrm{L} & 10 \mathrm{~L} \\ { }^{90} \mathrm{Sr} & 10 \mathrm{~L} & 100 \mathrm{~min} & 0.06 \mathrm{pCi} / \mathrm{L} & 10 \mathrm{~L} \\ { }^{99} \mathrm{Tc} & 4 \mathrm{~L} & 150 \mathrm{~min} & 1.0 \mathrm{pCi} / \mathrm{L} & 4 \mathrm{~L} \\ { }^{129} \mathrm{I} & 6,000 \mathrm{~L} \text { water } & -- & 0.000001 \mathrm{pCi} / \mathrm{L} & 1,500 \text { to } 3,000 \mathrm{~L} \\ \text { Gamma scan }\left({ }^{137} \mathrm{Cs}\right) & 750 \mathrm{~L} \text { water } & 1,000 \mathrm{~min} & 0.01 \mathrm{pCi} / \mathrm{L} & 750 \mathrm{~L} \\ \text { Gamma scan }\left({ }^{137} \mathrm{Cs}\right) & 4 \mathrm{~L} & 100 \mathrm{~min} & 6.0 \mathrm{pCi} / \mathrm{L} & 4 \text { to } 10 \mathrm{~L} \\ \text { Pu (isotopic) } & 750 \mathrm{~L} \text { water } & 1,000 \mathrm{~min} & 0.0002 \mathrm{pCi} / \mathrm{L} & 750 \mathrm{~L} \\ \text { U (isotopic) } & 1 \mathrm{~L} & 1,000 \mathrm{~min} & 0.06 \mathrm{pCi} / \mathrm{L} & 100 \text { to } 1,000 \mathrm{~mL}\end{array}$

Milk

$\begin{array}{lllll}{ }^{3} \mathrm{H} & 100 \mathrm{~mL} & 250 \mathrm{~min} & 300 \mathrm{pCi} / \mathrm{L} & 10 \mathrm{~mL} \\ { }^{90} \mathrm{Sr} & 4 \mathrm{~L} & 100 \mathrm{~min} & 2.0 \mathrm{pCi} / \mathrm{L} & 1 \mathrm{~L} \\ { }^{129} \mathrm{I} & 4 \mathrm{~L} & -- & 0.00001 \mathrm{pCi} / \mathrm{L} & 3 \text { to } 4 \mathrm{~L} \\ { }^{131} \mathrm{I}^{(\mathrm{e})} & 4 \mathrm{~L} & 100 \mathrm{~min} & 0.5 \mathrm{pCi} / \mathrm{L} & 4 \mathrm{~L} \\ \text { Gamma scan }\left({ }^{137} \mathrm{Cs}\right) & 4 \mathrm{~L} & 500 \mathrm{~min} & 8 \mathrm{pCi} / \mathrm{L} & 1 \mathrm{~L}\end{array}$

Fruit

$\begin{array}{lllll}{ }^{3} \mathrm{H} & 2 \mathrm{~kg} & 250 \mathrm{~min} & 300 \mathrm{pCi} / \mathrm{L} & 10 \mathrm{~mL} \text { (water) } \\ { }^{90} \mathrm{Sr} & 500 \mathrm{~g} & 200 \mathrm{~min} & 0.005 \mathrm{pCi} / \mathrm{g} & 100 \mathrm{~g} \\ { }^{129} \mathrm{I}(\mathrm{LEPD}){ }^{(e)} & 500 \mathrm{~g} & 200 \mathrm{~min} & 1.0 \mathrm{pCi} / \mathrm{g} & 50 \mathrm{~g} \\ \text { Gamma scan }\left({ }^{137} \mathrm{Cs}\right) & 500 \mathrm{~g} & 200 \mathrm{~min} & 0.02 \mathrm{pCi} / \mathrm{g} & 500 \mathrm{~g} \\ \mathrm{Pu} \text { (isotopic) } & 500 \mathrm{~g} & 1,000 \mathrm{~min} & 0.0004 \mathrm{pCi} / \mathrm{g} & 100 \mathrm{~g}\end{array}$

Produce and Farm Products

$\begin{array}{lllll}{ }^{90} \mathrm{Sr} & 500 \mathrm{~g} & 200 \mathrm{~min} & 0.005 \mathrm{pCi} / \mathrm{g} & 100 \mathrm{~g} \\ { }^{99} \mathrm{Tc} & 500 \mathrm{~g} & 150 \mathrm{~min} & 1.0 \mathrm{pCi} / \mathrm{g} & 5 \mathrm{~g}\end{array}$


Table III.A-1. (contd)

\begin{tabular}{|c|c|c|c|c|}
\hline Type of Analysis & $\begin{array}{c}\text { Approximate } \\
\text { Sample Size }\end{array}$ & $\begin{array}{c}\text { Nominal } \\
\text { Count } \\
\text { Time } \\
\end{array}$ & $\begin{array}{c}\text { Minimum } \\
\text { Detectable } \\
\text { Concentration }\end{array}$ & $\begin{array}{c}\text { Nominal Analysis } \\
\text { Aliquot Size }\end{array}$ \\
\hline Gamma scan $\left({ }^{137} \mathrm{Cs}\right)$ & $500 \mathrm{~g}$ & $200 \mathrm{~min}$ & $0.02 \mathrm{pCi} / \mathrm{g}$ & $500 \mathrm{~g}$ \\
\hline${ }^{239,240} \mathrm{Pu}$ & $500 \mathrm{~g}$ & $1,000 \mathrm{~min}$ & $0.0004 \mathrm{pCi} / \mathrm{g}$ & $100 \mathrm{~g}$ \\
\hline U (isotopic) & $500 \mathrm{~g}$ & $1,000 \mathrm{~min}$ & $0.02 \mathrm{pCi} / \mathrm{g}$ & $2 \mathrm{~g}$ \\
\hline
\end{tabular}

Beef

${ }^{90} \mathrm{Sr}$ $500 \mathrm{~g}$

$100 \mathrm{~min}$

$0.005 \mathrm{pCi} / \mathrm{g}$

$100 \mathrm{~g}$

Gamma scan $\left({ }^{137} \mathrm{Cs}\right) \quad 500 \mathrm{~g}$

$200 \mathrm{~min}$

$0.02 \mathrm{pCi} / \mathrm{g}$

$500 \mathrm{~g}$

Poultry

${ }^{90} \mathrm{Sr}$

$200 \mathrm{~g}$ (muscle)

$200 \mathrm{~min}$

$0.005 \mathrm{pCi} / \mathrm{g}$

$100 \mathrm{~g}$

Gamma scan $\left({ }^{137} \mathrm{Cs}\right)$

$500 \mathrm{~g}$ (muscle)

$200 \mathrm{~min}$

$0.02 \mathrm{pCi} / \mathrm{g}$

$500 \mathrm{~g}$

Eggs (without shells)

${ }^{90} \mathrm{Sr}$

Gamma scan $\left({ }^{137} \mathrm{Cs}\right)$

Wine

${ }^{3} \mathrm{H}$

Gamma scan $\left({ }^{137} \mathrm{Cs}\right)$

Fish Fillet

${ }^{90} \mathrm{Sr}$

${ }^{99} \mathrm{Tc}$

Gamma scan $\left({ }^{137} \mathrm{Cs}\right)$

$\mathrm{U}$ (isotopic)

Fish Carcass

${ }^{90} \mathrm{Sr}$

Gamma scan $\left({ }^{137} \mathrm{Cs}\right)$

Geese and Game Birds

${ }^{90} \mathrm{Sr}$

${ }^{99} \mathrm{Tc}$

Gamma scan $\left({ }^{137} \mathrm{Cs}\right)$
$500 \mathrm{~g}$

$500 \mathrm{~g}$

$500 \mathrm{~g}$

$500 \mathrm{~g}$

$500 \mathrm{~g}$

$500 \mathrm{~g}$

$500 \mathrm{~g}$ (bone)

$500 \mathrm{~g}$ (muscle)

$500 \mathrm{~g}$ (muscle)
$100 \mathrm{~min}$

$150 \mathrm{~min}$

$200 \mathrm{~min}$

$1,000 \mathrm{~min}$
$0.005 \mathrm{pCi} / \mathrm{g}$

$0.02 \mathrm{pCi} / \mathrm{g}$

$600 \mathrm{~min}$

$500 \mathrm{~min}$

$10 \mathrm{pCi} / \mathrm{L}$

$6.0 \mathrm{pCi} / \mathrm{L}$

$0.005 \mathrm{pCi} / \mathrm{g}$

$1.0 \mathrm{pCi} / \mathrm{g}$

$0.02 \mathrm{pCi} / \mathrm{g}$

$0.02 \mathrm{pCi} / \mathrm{g}$

$100 \mathrm{~min}$

$0.005 \mathrm{pCi} / \mathrm{g}$

$0.02 \mathrm{pCi} / \mathrm{g}$

$10 \mathrm{~g}$

$200 \mathrm{~min}$

$100 \mathrm{~min}$

$0.005 \mathrm{pCi} / \mathrm{g}$

$10 \mathrm{~g}$

$150 \mathrm{~min}$

$1.0 \mathrm{pCi} / \mathrm{g}$

$5 \mathrm{~g}$

$200 \mathrm{~min}$
$100 \mathrm{~g}$

$500 \mathrm{~g}$

$10 \mathrm{~mL}$ (distillate)

$1 \mathrm{~L}$

$100 \mathrm{~g}$

$5 \mathrm{~g}$

$500 \mathrm{~g}$

$2 \mathrm{~g}$ 
Table III.A-1. (contd)

\begin{tabular}{|c|c|c|c|c|}
\hline Type of Analysis & $\begin{array}{c}\text { Approximate } \\
\text { Sample Size }\end{array}$ & $\begin{array}{c}\text { Nominal } \\
\text { Count } \\
\text { Time }\end{array}$ & $\begin{array}{c}\text { Minimum } \\
\text { Detectable } \\
\text { Concentration }\end{array}$ & $\begin{array}{l}\text { Nominal Analysis } \\
\text { Aliquot Size }\end{array}$ \\
\hline $\mathrm{Pu}$ (isotopic) & $500 \mathrm{~g}$ (liver) & $1,000 \mathrm{~min}$ & $0.0004 \mathrm{pCi} / \mathrm{g}$ & $100 \mathrm{~g}$ \\
\hline U (isotopic) & $500 \mathrm{~g}$ (muscle) & $1,000 \mathrm{~min}$ & $0.02 \mathrm{pCi} / \mathrm{g}$ & $2 \mathrm{~g}$ \\
\hline
\end{tabular}

\section{Deer}

Gamma scan $\left({ }^{137} \mathrm{Cs}\right)$

$$
\begin{aligned}
& 500 \mathrm{~g} \text { (muscle) } \\
& 500 \mathrm{~g} \text { (bone) } \\
& 500 \mathrm{~g} \text { (liver) }
\end{aligned}
$$

$200 \mathrm{~min}$

$0.02 \mathrm{pCi} / \mathrm{g}$

$500 \mathrm{~g}$

${ }^{90} \mathrm{Sr}$

$100 \mathrm{~min}$

$0.005 \mathrm{pCi} / \mathrm{g}$

$10 \mathrm{~g}$

$\mathrm{Pu}$ (isotopic)

$1,000 \mathrm{~min}$

$0.0004 \mathrm{pCi} / \mathrm{g}$

$100 \mathrm{~g}$

\section{Rabbits}

${ }^{90} \mathrm{Sr}$

Gamma scan $\left({ }^{137} \mathrm{Cs}\right)$

$$
\begin{aligned}
& 500 \mathrm{~g} \text { (bone) } \\
& 500 \mathrm{~g} \text { (muscle) } \\
& 500 \mathrm{~g} \text { (liver) }
\end{aligned}
$$

$100 \mathrm{~min}$

$0.005 \mathrm{pCi} / \mathrm{g}$

$10 \mathrm{~g}$

$\mathrm{Pu}$ (isotopic)

$200 \mathrm{~min}$

$0.02 \mathrm{pCi} / \mathrm{g}$

$500 \mathrm{~g}$

$1,000 \mathrm{~min}$

$0.0004 \mathrm{pCi} / \mathrm{g}$

$100 \mathrm{~g}$

\section{Soil and Sediment}

${ }^{90} \mathrm{Sr}$

Gamma scan $\left({ }^{137} \mathrm{Cs}\right)$

Uranium (isotopic)

(LEPD) ${ }^{(\mathrm{e})}$

$\mathrm{Pu}$ (isotopic)

Native Vegetation

Gamma scan $\left({ }^{137} \mathrm{Cs}\right)$

${ }^{90} \mathrm{Sr}$

Total U

$\mathrm{Pu}$ (isotopic)
$1 \mathrm{~kg}$

$1 \mathrm{~kg}$

$1 \mathrm{~kg}$

$1 \mathrm{~kg}$

$500 \mathrm{~g}$

$500 \mathrm{~g}$

$500 \mathrm{~g}$

$500 \mathrm{~g}$
$100 \mathrm{~min}$

$0.005 \mathrm{pCi} / \mathrm{g}$

$100 \mathrm{~g}$

$200 \mathrm{~min}$

$1,000 \mathrm{~min}$

$0.02 \mathrm{pCi} / \mathrm{g}$

$650 \mathrm{~g}$

$100 \mathrm{~g}$

$1,000 \mathrm{~min}$

$0.0006 \mathrm{pCi} / \mathrm{g}$

$100 \mathrm{~g}$

\section{Direct Radiation Exposure}

Thermoluminescent

4 chips per holder

$500 \mathrm{~min}$

$0.02 \mathrm{pCi} / \mathrm{g}$

$500 \mathrm{~g}$

dosimeter

$200 \mathrm{~min}$

$0.005 \mathrm{pCi} / \mathrm{g}$

$100 \mathrm{~g}$

$-\quad: \quad 0.01 \mathrm{pCi} / \mathrm{g}$

$20 \mathrm{~g}$

$1,000 \mathrm{~min}$

$0.0004 \mathrm{pCi} / \mathrm{g}$

$100 \mathrm{~g}$

--- = Not applicable.
(a) Tritiated water vapor.
(b) Not routinely analyzed for.
(c) Four locations.
(d) Absolute sensitivity in the manner it is used is well below $1 \mathrm{mrem}$.
(e) LEPD $=$ low-energy photon detector. 
Table III.A-2. Chemical Monitoring Sampling Summary

\begin{tabular}{|c|c|c|}
\hline \multirow{2}{*}{ Constituent } & \\
\hline & Water, $\mu \mathrm{g} / \mathrm{L}$ & Solids, $\mu \mathrm{g} / \mathrm{Kg}$ \\
\hline \multicolumn{3}{|l|}{ Metals } \\
\hline Antimony & 0.02 & 10,000 \\
\hline Arsenic & 0.05 & 500 \\
\hline Beryllium & 0.1 & 200 \\
\hline Cadmium & 0.01 & 500 \\
\hline Chromium & 0.2 & 1,000 \\
\hline Copper & 0.1 & 2,000 \\
\hline Lead & 0.02 & 30 \\
\hline Mercury & 0.2 & 400 \\
\hline Nickel & 0.1 & 2,500 \\
\hline Selenium & 0.5 & 500 \\
\hline Silver & 0.05 & 1,000 \\
\hline Thallium & 0.02 & 500 \\
\hline Zinc & 0.3 & 1,000 \\
\hline \multicolumn{3}{|l|}{ Anions $^{(a)}$} \\
\hline Chloride & 200 & \\
\hline Fluoride & 100 & \\
\hline Sulfate & 500 & \\
\hline Nitrite & 20 & \\
\hline Nitrate & 20 & \\
\hline \multicolumn{3}{|l|}{ Volatile Organic Compounds ${ }^{(\mathbf{b})}$} \\
\hline Acetone & 5 & \\
\hline Benzene & 5 & \\
\hline Carbon tetrachloride & 5 & \\
\hline Chloroform & 5 & \\
\hline p-Dichlorobenzene & 5 & \\
\hline 1,1-Dichloroethane & 5 & \\
\hline 1,2-Dichloroethane & 5 & \\
\hline 1,2-Dichloroethylene (cis and trans) & 5 & \\
\hline Methylene chloride & 5 & \\
\hline 2-Butanone & 5 & \\
\hline 4-Methyl-2-pentanone & 5 & \\
\hline Tetrachloroethylene & 5 & \\
\hline Toluene & 5 & \\
\hline
\end{tabular}


Table III.A-2. (contd)

\begin{tabular}{lccr}
\multicolumn{1}{c}{ Constituent } & & Water, $\mu \mathrm{g} / \mathrm{L}$ & Solids, $\mu \mathrm{g} / \mathrm{Kg}$ \\
\cline { 1 - 1 } 1,1,1-Trichloroethane & 5 & \\
1,1,2-Trichloroethane & 5 \\
Trichloroethylene & 5 \\
Vinyl chloride & 5 \\
Total xylene & 5 \\
1-Butanol & 5 \\
Propionitrile & 5
\end{tabular}

(a) Method 300.0 (EPA-600/4-79-020).

(b) Method 8260 (SW-846).

\section{Air Samples}

Alpha- and beta-emitting radionuclides are measured by a direct count from the glass fiber filter ( $>99 \%$ efficient for $0.3-\mu \mathrm{m}$ particles). Alpha radiation is counted on a low-background, gas-flow proportional counter; beta radiation is counted on a gas-flow proportional counter.

Gamma-emitting radionuclides are counted directly from glass fiber filters using lithium-ion drifted germanium (Ge[Li]) or hyperpure germanium (HPGE) detectors with a multichannel, pulse-height analyzer. Listed below are the radionuclides that are reported for detectable concentrations (i.e., when net counts exceed the 2-sigma total propagated analytical uncertainty):

$\begin{array}{llllll}{ }^{7} \mathrm{Be}^{(a)} & { }^{54} \mathrm{Mn} & { }^{65} \mathrm{Zn} & { }^{106} \mathrm{Ru}^{(a)} & { }^{137} \mathrm{Cs}^{(a)} & { }^{152} \mathrm{Eu} \\ { }^{22} \mathrm{Na} & { }^{59} \mathrm{Fe} & { }^{95} \mathrm{ZrNb} & { }^{125} \mathrm{Sb}^{(a)} & { }^{140} \mathrm{BaLa} & { }^{154} \mathrm{Eu}^{(a)} \\ { }^{24} \mathrm{Na} & { }^{58} \mathrm{Co} & { }^{99} \mathrm{Mo} & { }^{131} \mathrm{I} & { }^{140} \mathrm{Ce} & { }^{155} \mathrm{Eu}^{(a)} \\ { }^{40} \mathrm{~K}^{(\mathrm{a})} & { }^{60} \mathrm{Co}^{(a)} & { }^{103} \mathrm{Ru} & { }^{134} \mathrm{Cs}^{(a)} & { }^{144} \mathrm{CePr} & \end{array}$

(a) Routinely reported for all samples.

Strontium-90 is leached from glass fiber filters with fuming nitric acid, scavenged with barium chromate and ammonium hydroxide, precipitated as a carbonate, transferred to a stainless-steel planchet, and counted with a low-background, gas-flow proportional counter. After $15 \mathrm{~d}$, the ${ }^{90} \mathrm{Sr}$ decay product is separated and counted with a proportional counter.

Uranium is leached from glass fiber filters with nitric acid, converted to the chloride form, and loaded onto an anion-exchange column. The effluent is then polonium decontaminated with ascorbic 
acid and copper disk treatment. The uranium is then extracted with anhydrous ether. The sample is then electrodeposited onto a stainless-steel planchet and counted with an alpha spectrometer to determine the uranium isotopic concentrations.

Plutonium is leached from glass fiber filters with nitric acid and passed through an anion-exchange resin. The plutonium on the resin column is eluted with hydrochloric acid containing ammonium iodide, electrodeposited on a stainless-steel disk, and then counted with an alpha spectrometer to determine the ${ }^{238} \mathrm{Pu}$ and ${ }^{239,240} \mathrm{Pu}$ concentrations.

Americium-241 concentrations are determined through the use of the eluate from the plutonium anion-exchange resin column. A calcium oxalate precipitation is performed. The americium is then extracted with dibutyl N,N-diethylcarbamylphosphate (DDCP) and passed through a cation-exchange resin column to remove iron and thorium. The americium is eluted from the resin with highconcentration hydrochloric acid, electrodeposited on a stainless-steel disk, and then counted by alpha spectrometry.

Tritium is collected as tritiated water vapor using silica gel. The water vapor is removed from the gel by heat and vacuum action, and then collected in a freeze trap. The tritium content of the water vapor is determined with a liquid scintillation spectrometer.

Iodine-131 is collected on triethylene-di-amine (TEDA)-treated activated charcoal ( $90 \%$ and $70 \%$ efficient for methyl iodine at 2.6 and $5.2 \mathrm{~m}^{3} / \mathrm{h}$, respectively) and then counted on either a $\mathrm{Ge}(\mathrm{Li})$ or HPGE detector with a multichannel, pulse-height analyzer.

Iodine-129 is collected on a special petroleum-based charcoal. Iodine is removed from the charcoal, purified, and determined by mass spectrometry.

Carbon-14 is collected as a carbon dioxide gas using soda lime. The carbon dioxide is released from the soda-lime sample with acid and injected into a benzene synthesizer instrument. The carbon dioxide is quantitatively converted to benzene through a series of catalytic reactions. The benzene product is mixed with scintillation solution and counted on a low-temperature, liquid scintillation counter.

Krypton-85 is collected using a gas cylinder. The air sample is purified using a specially constructed cryogenic chromatograph. The sample is passed through a series of cold traps to remove unwanted gases. The purified ${ }^{85} \mathrm{Kr}$ is then mixed with scintillation solution and counted on a low-temperature, liquid scintillation counter.

\section{Water Samples}

Alpha-emitting radionuclide (americium, neptunium, plutonium, and uranium) samples are treated with nitric acid and dried according to the methods given in SW-846. The residue is secured on a stainless-steel planchet using a collodion solution and counted with a low-background, gas-flow proportional counter.

Beta-emitting radionuclide samples are dried in the same way as the alpha-emitting radionuclides, and are then counted directly using a gas-flow proportional counter. 
Gamma-emitting radionuclides are counted directly from $500 \mathrm{~mL}$ of sample concentrate using either a $\mathrm{Ge}(\mathrm{Li})$ or HPGE detector with a multichannel, pulse-height analyzer. See air samples discussion for a list of radionuclides included in gamma scan analysis.

Strontium-90 in large-volume water samples is measured in the same manner as in air samples, but the sample is acidified and boiled down, neutralized with ammonium hydroxide, and precipitated as the carbonate before exposure to fuming nitric acid.

Technetium- 99 concentrations are determined using technetium separation by iron hydroxide precipitation followed by a carbonate precipitation. Further purification from interfering nuclides is performed by anion-exchange resin separation. The ${ }^{99} \mathrm{Tc}$ is counted by liquid scintillation spectrometry.

Tritium samples can be counted directly with a liquid scintillation spectrometer, or the sample can be enriched by alkaline electrolysis and then counted with a liquid scintillation spectrometer.

Uranium in the water sample is adsorbed onto anion resin following wet ashing, purified, electrodeposited onto a stainless-steel planchet, and then counted with an alpha spectrometer to determine uranium isotopic concentrations.

Filter-resin samples are analyzed for gamma-emitting radionuclides using either a Ge(Li) or HPGE detector with a multichannel, gamma-ray spectrometer. Aliquots of the resin samples are analyzed by chemical separation and alpha spectrometry for plutonium.

Iodine-129 analysis in water is determined by oxidation of the sample to "trap" the iodine on a charcoal absorber. The iodine is further processed and separated, loaded onto a thermal ionization mass spectrometer triple filament assembly, and counted on the mass spectrometer for iodine isotopic concentrations.

Volatile organic compounds are determined by SW-846 Methods $8010 / 8020,8240$ or 8260 . Volatile compounds are introduced in the gas chromatograph by the purge-and-trap method. The components may then be further separated via the gas chromatograph and detected using a mass spectrometer.

For the determination of metals, samples are first digested in nitric acid. Some metals are determined by inductively coupled plasma/mass spectrometry (ICP/MS) and others by graphite furnace atomic absorption (GFAA) spectrometry using EPA-821/R-96-005 Method 1638 or EPA-821/R-96-006 Method 1639.

Mercury is determined by oxidizing the samples with bromine monochloride, which breaks down organomercury bonds. Mercuric ions in the oxidized sample are reduced to elemental mercury with tin chloride, and then purged onto a gold trap as a means of preconcentration and interference removal. Mercury vapor is thermally desorbed into the fluorescence pathway. Mercury is analyzed using cold vapor atomic fluorescence (CVAF) spectroscopy according to EPA-600/R-94-111 Method 245.1.

The anions (nitrate, nitrite, chloride, fluoride, and sulfate) are determined using EPA-600/4-79-020 Method 300.0. The sample is introduced into an ion chromatograph, and the anions of interest are separated and measured. 
Milk

Gamma-emitting radionuclides in milk are counted directly using either a Ge(Li) or HPGE detector with a multichannel, pulse-height analyzer.

Tritium in water distilled from milk is counted directly with a liquid scintillation spectrometer.

Iodine- 129 is separated from milk with an anion-exchange resin, purified, and analyzed by mass spectrometry.

Iodine-131 is removed from milk with an anion-exchange resin. The iodine is eluted with sodium hypochlorite, purified, precipitated as palladium iodide, and beta counted with a low-background, gasflow proportional counter.

Strontium-90 is measured in the same manner as in air samples, but samples are purified with a cation resin, eluted with sodium chloride, and precipitated as a carbonate before exposure to fuming nitric acid.

\section{Foodstuffs}

Gamma-emitting radionuclides in foodstuffs are counted directly on either a Ge(Li) or HPGE detector with a multichannel, pulse-height analyzer.

Tritium in water distilled from farm produce is counted directly with a liquid scintillation spectrometer.

Iodine-129 in foodstuffs (other than milk) is determined after the sample is dried and weighed. The dried sample is counted directly with a low-energy photon detector (LEPD) system.

Plutonium-238 and ${ }^{239,240} \mathrm{Pu}$ in foodstuffs are measured in the same manner as in air samples, after samples have been dried, ashed in a furnace, and treated with nitric acid.

Strontium-90 is measured in the same manner as in air samples, but samples are dried, ashed in a furnace, and treated with nitric acid before exposure to fuming nitric acid.

For ${ }^{99} \mathrm{Tc}$ determination, the sample is digested to inorganic salts with nitric acid and hydrogen peroxide, and the digestate is processed in the same manner as for water samples.

Uranium isotopic concentrations in foodstuffs is dry and/or wet ashed to an inorganic salt. The salts are dissolved in nitric acid and extracted into hexone for purification. The sample is then electrodeposited onto a stainless-steel planchet and counted with an alpha spectrometer.

\section{Vegetation and Wildlife}

For ${ }^{99} \mathrm{Tc}$ determination, the sample is digested to inorganic salts with nitric acid and hydrogen peroxide and the digestate is processed in the same manner as for water samples. 
Plutonium, strontium, uranium (isotopic), and gamma-emitting radionuclides are measured using the procedures described for foodstuffs.

\section{Soil and Sediment}

All soil and sediment samples are pretreated by weighing, drying, and ball milling to a constant particle size of 300 microns or less. Samples not requiring further pretreatment are counted directly to detect gamma- and low-energy photon-emitting radionuclides. For plutonium and strontium analyses requiring chemical separations, $1-\mathrm{g}$ aliquots of samples are dissolved with concentrated acids by heating in pressurized containers in a microwave oven.

Gamma-emitting radionuclides are counted on either a $\mathrm{Ge}(\mathrm{Li})$ or HPGE detector with a multichannel, pulse-height analyzer after the sample is placed in a Marinelli beaker.

Plutonium and ${ }^{90} \mathrm{Sr}$ are measured after the sample is pretreated. Strontium is precipitated from the sample as strontium oxalate. The sample is then converted and precipitated as a carbonate; transferred to a planchet; and counted with a low-background, gas-flow proportional counter. After the strontium has been removed from the sample, the plutonium is coprecipitated with calcium oxalate, dissolved, and loaded onto an ion-exchange resin column. The plutonium is eluted from the resin column with nitric and hydrofluoric acids, deposited on a stainless-steel or platinum disk, and counted with an alpha spectrometer.

Uranium analysis is conducted after the sample is pretreated using an ion-exchange column. The sample is counted directly with an LEPD system.

Trace metals analysis is performed on designated soil and sediment samples by digestion using a nitric, perchloric, and hydorfluoric acid treatment with heating in a sealed teflon bomb. Methods 245.5 (cold vapor atomic adsorption [CVAA]) (EPA-600/4-79-020) and 200.9 (GFAA) (EPA-600/R-94-111) are used to determine mercury and other metals by GFAA and ICP/MS in the digestate.

\section{Exceptions}

No exceptions have been taken to should* statements in DOE/EH-0173T.

\section{Quality Assurance and Quality Control}

In achieving the surveillance objectives identified in previous subsections, it is imperative that knowledge is maintained about the accuracy, precision, traceability, and limitations of data and information supporting project documentation. It is also imperative that an appropriate methodology to ensure control and legitimacy of project documentation are maintained. The quality of results is dependent on the control and verification of all components that provide input into the generation of reports and documentation. All components of work performed within the project are under an appropriate level of quality assurance (QA) and quality control (QC) scrutiny. 
The goal of the QA/QC program is to ensure that accurate, defensible data are produced. This subsection describes the elements of the program and how they are implemented. In obtaining the QA/QC goal, a management commitment to operating a surveillance project that accurately reflects Hanford Site environmental impacts and radiation doses to the environment and public is required. Management commitment to QA/QC is ensured through PNNL-established management philosophies and is implemented through the Standards-Based Management System (PNNL 1997).

\section{Requirements}

The DOE QA requirements are contained in DOE Order 5700.6C, which replaced DOE Order 5700.6B as defined in DOE/EH-0173T. DOE Order 5700.6C requires that QA plans be developed and documented and recommends the judicious and selective application of appropriate and recognized standards. The DOE Order addresses 10 key elements but does not address environmental surveillance specifically. These requirements are implemented through the Standards-Based Management System (PNNL 1997), which gives direction for developing an activity-specific QA plan.

\section{Quality Assurance Plan}

Surface environmental surveillance is conducted under a project-specific QA plan. The QA plan addresses the 18 criteria of The American Society of Mechanical Engineers (ASME) NQA-1-1989 Edition, which meets the majority of the DOE Order $5700.6 \mathrm{C}$ requirements, and is approved by PNNL.

\section{Assessments}

Independent assessments are performed on project activities and procedures to ensure compliance with project, PNNL, and DOE QA requirements. These assessments are initiated by the DOE-RL program manager, the PNNL project manager, the media task leader, or the quality engineer on a routine and/or random basis. Assessment results are documented and then reported and reviewed by responsible management and media task leaders. Corrective actions are taken, documented, and verified as applicable.

\section{Quality Control}

\section{Procedures}

The QC for quality-affecting activities is maintained through written procedures. Quality-affecting activities and required written procedures are identified in the project-specific QA plan.

In addition, QA/QC for service functions is defined in statements of work issued to the performing functional organization, whether internal to PNNL or those of an external contractor. The PNNL service functions are performed according to the QA plan and procedures established for that function, unless the statement of work identifies special requirements.

\section{Analytical Quality Control Program}

Contracted analytical laboratories are required to maintain and participate in analytical QA programs to determine analytical precision and accuracy and to operate under written and approved procedures, as 
defined by a contract statement of work. Reports are generated periodically (monthly or quarterly) to summarize intralaboratory QC data and performance. The QC reports, minimum detectable concentrations, and method detection limit determinations are reviewed by the task leader; deficiencies are identified and investigated. Corrective actions are documented, implemented, and verified. In addition to the laboratory's internal QC program, participation in national intercomparison studies is required.

Radiochemistry. The majority of the intralaboratory QC program consists of analyzing blanks, replicates, and National Institute of Standards and Technology-traceable spike samples (which must comprise no less than $15 \%$ of all ordered tests) and maintaining data that validate determinations of current minimum detectable concentrations. Requirements for accuracy and precision for internal analytical QA are addressed below in Analytical Accuracy and Precision Criteria. Quarterly reports are generated to summarize intralaboratory QC data and performance. Use of Equation 37 from Chapter 6 in EPA 520/1-80-012 is designated for the determination of the minimum detectable concentration.

The contracted analytical laboratory participates in two national intercomparison studies. The laboratory is required to analyze applicable radionuclide-media samples from the DOE Quality Assessment Program operated by the Environmental Measurements Laboratory and the EPA Environmental Radioactivity Laboratory Intercomparison Studies Program. Additional QC data are generated by sending split or collocated (blind) duplicate samples to the laboratory and independent organizations (i.e., state, U.S. Food and Drug Administration, EPA) and challenging the laboratory with characterized (blind) reference samples as described in the project analytical QC plan. The characterized (blind) reference samples are developed to challenge the capabilities of the laboratory in areas of significance (important pathway radionuclide-media or historically weak analytical areas). Reference sample material is obtained from the National Institute of Standards and Technology, DOE, EPA, or other sources with a significant level of reliability and accountability. Criteria used for judging the performance on QC samples are derived from appropriate references (e.g., EPA-600/4-81-004, EML-587).

Reports of contractor performance in the DOE and EPA programs are required. Performances on blind samples (split or characterized reference) are evaluated by QC technical support personnel and reported to project management. These documents are reviewed and corrective actions (i.e., follow-up audits) taken if necessary.

The current radiochemistry analytical contract is with Quanterra Environmental Services, Richland, Washington, for all radiochemistry (except ${ }^{129} \mathrm{I}$ ) analyses. PNNL performs ${ }^{129} \mathrm{I}$ analyses under a statement of work.

Chemical (Nonradiochemical) Analysis. The QC program for the chemical laboratories providing services consists of analyzing blanks, replicates, matrix spikes, matrix spike duplicates, and laboratory control samples. The QC data are reported with the sample results.

The laboratories participate in the EPA Water Pollution and Water Supply Performance Evaluation studies. Additional QC data are generated by sending split or collocated (blind) duplicate samples to the laboratory and independent organizations (i.e., state, EPA) and challenging the laboratory with characterized (blind) reference samples as described in the project analytical QC plan. Reference sample material is obtained from the National Institute of Standards and Technology, DOE, EPA, or other sources with a significant level of reliability and accountability. 
Accuracy and precision requirements meet EPA reference procedure or program requirements or, in the case of a PNNL laboratory, the laboratory-specific QA plan requirements, which are:

$\begin{array}{lllc} & \text { Water } & & \text { Soil/Sediment } \\ \text { Accuracy } & \pm 25 \% & & \pm 25 \% \\ \text { Precision } & \pm 20 \% & & \pm 25 \%\end{array}$

The EPA intercomparison programs reports of performance are required for the commercial laboratory performing analytical services for the project. Performances on blind samples (split or characterized reference) are evaluated by QC technical support personnel and reported to project management. These documents are reviewed and corrective actions (i.e., follow-up audits) taken if necessary.

The current commercial chemical analysis contract is with Quanterra Environmental Services, St. Louis, Missouri. Some metals analyses are performed by PNNL.

\section{Analytical Accuracy and Precision Criteria}

Radiochemical data-accuracy criteria call for analytical results of spiked samples to be within $20 \%$ to $30 \%$ of the known spike value: Accuracy is assessed using spiked samples and the criterion that $95 \%$ of the spiked sample results fall within the accuracy range given in Table III.A-3 for the various analysis types.

Precision requirements are met when replicate results (above detectable concentrations) fall within $\pm 30 \%$ relative percent difference for water samples and within three standard deviations for all other media samples.

Table III.A-3. Accuracy Requirements

\begin{tabular}{lcc}
\multicolumn{1}{c}{ Type of Analysis } & Precision \\
\cline { 1 - 1 } Gamma spectrometry & & $\pm 20 \%$ \\
Liquid scintillation & $\pm 20 \%$ \\
Liquid scintillation with chemical separation & & $\pm 30 \%$ \\
Alpha spectrometry & & $\pm 25 \%$ \\
Beta proportional & & $\pm 30 \%$ \\
Alpha proportional & & $\pm 30 \%$ \\
Alpha-gamma coincidence & $\pm 25 \%$ \\
Beta-gamma coincidence & $\pm 25 \%$ \\
Uranium total, fluorimetry or phosphorimetry & $\pm 30 \%$ \\
Uranium isotopic, gamma (low-energy photon & $\pm 30 \%$
\end{tabular}

spectroscopy) 
Accuracy and precision of analytical results are assessed by analyzing spikes, blanks, and replicate samples. Such samples comprise no less than $15 \%$ of all ordered radiochemical tests. For nonradiochemical tests ordered, QC criteria are defined above in Chemical Analysis. Spikes and blanks are included in each batch of samples. Spikes have, insofar as possible, the matrix, volume, and other relevant characteristics of the actual samples being analyzed. Blanks are matrix or reagent blanks. Reagent and sample media blanks will be analyzed with each batch of samples.

\section{Field Radiation Survey Instruments}

Field survey instruments are calibrated with appropriate radiation sources and standards traceable to the National Institute of Standards and Technology. Calibration methods and frequencies for field survey equipment are determined and controlled by the PNNL Radiation Standards and Calibration Project, which provides radiation calibration service (including pick up and delivery) to the Hanford Site. Special studies are performed periodically by technical support personnel to characterize detection capabilities of more complex instruments. Instruments are performance tested with appropriate check sources before and during (if required procedurally) surveys. Instruments determined not to be performing adequately are returned to the PNNL Radiation Standards and Calibration Project for maintenance and calibration.

\section{Exceptions}

No exceptions have been taken to should* statements in DOE/EH-0173T.

\section{Records Management and Reporting}

This subsection identifies and outlines the plans for record keeping and reporting to meet applicable requirements.

General record-keeping and reporting requirements are outlined in DOE Orders 5400.1 and 5400.5 and DOE/EH-0173T. These DOE Orders and guidance specify the reporting responsibilities, timing, and distribution of routine reports and contain some details on the required content and format. Requirements for preparing and distributing accident and occurrence reports are outlined in DOE Orders 225.1, 232.1, and 5484.1.

\section{Record Keeping}

DOE Order 5400.1 (pp. IV-3 and IV-8) and DOE Order 5400.5 (p. II-15) require the maintenance and retention of auditable records relating to environmental surveillance, the fate of radioactive materials in the environment and their impact on radiation doses to the public, records of calculations, computer programs, raw data, procedures, etc. Records are to be protected against damage or loss; generally, this means separate storage of duplicates. DOE Guide 1324.5B establishes requirements for the retention and disposal of environmental contamination measurement records, which apply to surveillance records. DOE Order 5700.6C establishes QA requirements. 
These record-keeping requirements are implemented by the PNNL QA plan, which conforms to the requirements of DOE Order 5700.6C and 10 CFR 830.120 as interpreted and implemented by PNNL (1997).

\section{Reporting}

The reporting requirements applicable to environmental surveillance are contained in the following:

- DOE Orders 5400.1 and 231.1

- annual Hanford Site environmental report to be submitted to DOH-HQ and the public by October 1 of the following year

Surveillance results are formally reported through the annual Hanford Site environmental report (e.g., PNNL-11472). The distribution of the report is reviewed each year to ensure that potentially affected federal, state, and local governments and agencies; Indian Nations; environmental interests; business interests; and owners of Hanford Reach islands are notified concerning the environmental status of the site and surroundings.

- preoperational environmental survey report

- environmental monitoring plan to be reviewed annually and updated at least every 3 yr

The monitoring plan is maintained per DOE Order 5400.1 and DOE/EH-0173T; the preoperational report will be prepared as directed by DOE-RL. Topical reports describing the fate of radioactive materials in the environment are issued periodically, for information not reportable through the reports listed above, to meet site-specific and public assurance needs.

- DOE Orders 225.1, 232.1, and 5484.1

- occurrence reporting: submit emergency, unusual occurrence, or off-normal occurrence reports (e.g., environmental releases of significant offsite consequences, threatening or degrading to the environment, exceedances of compliance or administrative limits, or degradation of compliance monitoring systems)

- notifications: submit notifications (e.g., damages, releases to the environment, occurrences resulting in press releases, or discovery of significant contamination)

Occurrences are reported as required by the cited DOE Orders.

- DOE Order 5400.5

- noncompliance: requires reporting when requirements will not be or have not been met (p. I-4)

- potential doses exceeding reporting limits: requires reporting actual or potential exposures of the public that could result in either 1) a dose from DOE sources exceeding $10 \mathrm{mrem}$ EDE in a year, 
or exceeding any limit or failing to meet any other requirement specified, or any other legal or applicable limits; or 2) a combined dose equal to or greater than 100 mrem EDE in a year from DOE and other anthropogenic sources.

Noncompliances with the DOE Order are reported as required.

Unusual results or trends in surveillance data that occur between issuances of the annual Hanford Site environmental report (e.g., PNNL-1 1472) are reported when they occur to DOE-RL and to the appropriate facility managers. Unusual report levels have been established, based on the environmental concentrations that would lead to an offsite public dose of either 1 or $10 \mathrm{mrem} / \mathrm{yr}$, depending on the media, assuming that the condition persisted for an entire year. Unusual report levels to be utilized are shown in Table III.A-4.

\section{Exceptions}

No exceptions have been taken to should* statements in DOE/EH-0173T.

\section{References}

ANSI (American National Standards Institute) N42.17. 1989. Performance Specifications for Health Physics Instrumentation: (A) Portable Instrumentation for Use in Normal Environmental Conditions; (B) Occupational Airborne Radioactivity Monitoring Instrumentation; and (C) Portable Instrumentation for Use in Extreme Environmental Conditions. Institute of Electrical and Electronics Engineers, Inc., New York.

ASME (The American Society of Mechanical Engineers) NQA-1-1989 Edition. 1989. Quality Assurance Program Requirements for Nuclear Facilities, An American National Standard. New York.

ARH-CD-775. 1976. Geohydrologic Study of the West Lake Basin. R. E. Gephart, P. A. Eddy, R. C. Arnett, and G. A. Robinson, Atlantic Richfield Hanford Company, Richland, Washington.

BHI-EE-09. Environmental Data Management Procedures Manual. In Library, ERC Controlled Manual List [Online]. Available URL: http://www.erc.rl.gov/

BNWL-90. 1965. Evaluation of Radiological Conditions in the Vicinity of Hanford for 1964. R. F. Foster and R. H. Wilson, Pacific Northwest Laboratory, Richland, Washington.

BNWL-316. 1966. Evaluation of Radiological Conditions in the Vicinity of Hanford for 1965. R. F. Foster, Pacific Northwest Laboratory, Richland, Washington.

BNWL-439. 1967. Evaluation of Radiological Conditions in the Vicinity of Hanford for 1966. J. F. Honstead, Pacific Northwest Laboratory, Richland, Washington.

Issued: November 10, 1997 
Table III.A-4. Hanford Site Surface Environmental Surveillance Concentration Reporting Levels ${ }^{(a)}$

\begin{tabular}{|c|c|c|c|c|c|c|c|c|c|c|c|c|c|c|}
\hline & ${ }^{3} \mathrm{H}$ & ${ }^{60} \mathrm{Co}$ & ${ }^{85} \mathrm{Kr}$ & ${ }^{90} \mathrm{Sr}$ & ${ }^{99} \mathrm{Tc}$ & ${ }^{106} \mathrm{Ru}$ & ${ }^{129} \mathrm{I}$ & ${ }^{13} I_{I}$ & ${ }^{137} \mathrm{Cs}$ & ${ }^{154} \mathrm{Eu}$ & Natural U & ${ }^{234,5,8} \mathrm{U}$ & ${ }^{238,9 / 40} \mathrm{Pu}$ & ${ }^{241} \mathrm{Am}$ \\
\hline Air, $p C i / m^{3}$ & 1.2E+02 & $2.7 \mathrm{E}-01$ & $3.0 \mathrm{E}+04$ & $7.2 \mathrm{E}-02$ & (b) & $1.8 \mathrm{E}-01$ & $2.8 \mathrm{E}-03$ & 4.7E-02 & $1.1 \mathrm{E}-01$ & $\ldots$ & -.. & $8.0 \mathrm{E}-04$ & $3.9 \mathrm{E}-04$ & -- \\
\hline River water, $\mathrm{pCi} / \mathrm{L}$ & $1.0 \mathrm{E}+04$ & $1.7 \mathrm{E}+00$ & -- & $3.0 \mathrm{E}-01$ & $8.4 \mathrm{E}+00$ & $1.5 \mathrm{E}+00$ & 7.3E-01 & 2.7E-00 & $3.5 \mathrm{E}-02$ & -- & $3.3 \mathrm{E}+00$ & $3.3+00$ & $1.1 \mathrm{E}+00$ & -- \\
\hline $\begin{array}{l}\text { Drinking water, } \\
\text { pCi/L }\end{array}$ & $2.0 \mathrm{E}+04$ & $5.0 \mathrm{E}+01$ & --- & $1.0 \mathrm{E}+01$ & $6.2 \mathrm{E}+02$ & (c) & $5.0 \mathrm{E}+00$ & $3.0 \mathrm{E}+01$ & $3.0 \mathrm{E}+01$ & -- & (c) & $5.0 \mathrm{E}+00$ & (c) & $\cdots$ \\
\hline $\begin{array}{l}\text { Dairy products, } \\
\mathrm{pCi} / \mathrm{L}\end{array}$ & $5.4 \mathrm{E}+04$ & (c) & -- & $2.7 \mathrm{E}-01$ & $\cdots$ & (c) & $1.3 \mathrm{E}+01$ & $8.1 \mathrm{E}+01$ & $8.1 \mathrm{E}+01$ & $\ldots$ & $\cdots$ & (c) & (c) & $\cdots$ \\
\hline $\begin{array}{l}\text { Meats, poultry, } \\
\text { eggs, pCi/g wet } \\
\text { weight }\end{array}$ & $1.8 \mathrm{E}+02$ & (c) & $\cdots$ & $9.1 \mathrm{E}-02$ & --- & (c) & (c) & (c) & $2.7 \mathrm{E}-01$ & $\cdots$ & $\cdots$ & (c) & (c) & $\cdots$ \\
\hline $\begin{array}{l}\text { Cereals and } \\
\text { grains, pCi/g }\end{array}$ & $1.8 \mathrm{E}+02$ & (c) & $\cdots$ & $9.1 \mathrm{E}-02$ & -- & (c) & (c) & (c) & $2.7 \mathrm{E}-01$ & $\cdots$ & +- & (c) & $2.5 \mathrm{E}-01$ & -- \\
\hline $\begin{array}{l}\text { Leafy vegetables, } \\
\mathrm{pCi} / \mathrm{g}\end{array}$ & $5.0 \mathrm{E}+02$ & (c) & $\therefore$ & $2.7 \mathrm{E}-01$ & $1.5 \mathrm{E}+01$ & (c) & $1.3 \mathrm{E}-01$ & (c) & $6.0 \mathrm{E}-01$ & $\cdots$ & -- & (c) & (c) & $\cdots$ \\
\hline $\begin{array}{l}\text { Fruit and other } \\
\text { vegetables, pCi/g }\end{array}$ & $5.0 \mathrm{E}+01$ & (c) & $\cdots$ & $2.5 \mathrm{E}-02$ & $1.3 \mathrm{E}+00$ & (c) & $1.2 \mathrm{E}-02$ & (c) & $6.0 \mathrm{E}-02$ & $\cdots$ & $\cdots$ & $1.1 \mathrm{E}-01$ & $6.2 \mathrm{E}-02$ & - \\
\hline Wine, ${ }^{(d)} \mathrm{pCi} / \mathrm{L}$ & $2.0 \mathrm{E}+05$ & $\cdots$ & $\cdots$ & (c) & $\cdots$ & $\cdots$ & (c) & (c) & $3.0 \mathrm{E}+02$ & $\cdots$ & $\cdots$ & (c) & (c) & $\cdots$ \\
\hline $\begin{array}{l}\text { Wildlife meats, }{ }^{(e)} \\
\text { pCi/g }\end{array}$ & -- & $9.1 \mathrm{E}-01$ & $\cdots$ & $1.8 \mathrm{E}-01$ & $1.1 \mathrm{E}+01$ & $\cdots$ & $\cdots$ & $\ldots$ & $5.4 \mathrm{E}-01$ & -- & $\cdots$ & $9.5 \mathrm{E}-01$ & $5.0 \mathrm{E}-01$ & -- \\
\hline Soil, ${ }^{(1)} \mathrm{pCi} / \mathrm{g}$ & (c) & (c) & -- & $3.0 \mathrm{E}-01$ & $\cdots$ & (c) & (c) & (c) & $5.8 \mathrm{E}+00$ & $\cdots$ & $8.0 \mathrm{E}+00$ & $3 . E+00$ & $3.7 \mathrm{E}+00$ & $5.5 \mathrm{E}-01$ \\
\hline $\begin{array}{l}\text { Vegetation and } \\
\text { alfalfa, pCi/g }\end{array}$ & (c) & (c) & -- & $1.5 \mathrm{E}+00$ & $1.6 \mathrm{E}+02$ & (c) & (c) & (c) & 2.7E-01 & $\cdots$ & $1.3 \mathrm{E}+01$ & $6.6 \mathrm{E}+00$ & $4.2 \mathrm{E}+03$ & $\ldots$ \\
\hline Sediment, pCi/g & (c) & $1.4 \mathrm{E}+00$ & -- & $3.0 \mathrm{E}+04$ & (c) & $1.4 \mathrm{E}+011$ & (c) & (c) & $6.0 \mathrm{E}+00$ & $2.6 \mathrm{E}+00$ & (c) & $5.0 \mathrm{E}+01$ & $8.1 \mathrm{E}+04$ & -- \\
\hline
\end{tabular}

$\ldots=$ Not applicable.

(a) Concentrations are shown to two significant figures for consistency, but this does not imply the analytical precision, which varies with measurement type, or the precision of the dose model used. .

(b) Not routinely analyzed and/or not considered a significant dose contributor.

(c) Analysis is not typically reported, but determinations of other reportable levels included this medium-radionuclide pathway dose contribution.

(d) Based on estimated maximally exposed individual consumption rate of $70 \mathrm{~L}(\sim 100$ bottles) of wine per year.

(e) Based on estimated maximally exposed individual consumption rate of $40 \mathrm{~kg}$ of wildlife meat per year (from fish, deer, fowl, etc.); tritium concentrations are accounted for in fish only (not other wildlife types) from the river-water pathway calculation.

(f) Reporting levels for ${ }^{90} \mathrm{Sr}$ and ${ }^{137} \mathrm{Cs}$ in soil based on $\sim 10$ mrem effective dose equivalent. 
BNWL-983. 1969. Evaluation of Radiological Conditions in the Vicinity of Hanford for 1967. J. P. Corley and C. B. Woolridge, Pacific Northwest Laboratory, Richland, Washington.

BNWL-1341. 1970. Evaluation of Radiological Conditions in the Vicinity of Hanford for 1968. W. L. Fisher and C. B. Wilson, Pacific Northwest Laboratory, Richland, Washington.

BNWL-1505. 1970. Evaluation of Radiological Conditions in the Vicinity of Hanford for 1969. J. P. Corley, Pacific Northwest Laboratory, Richland, Washington.

BNWL-1669. 1973. Environmental Surveillance at Hanford for CY-1970. J. P. Corley, Pacific Northwest Laboratory, Richland, Washington.

BNWL-SA-4534. 1973. An Analytical Technique for Distributing Air Sampling Locations Around Nuclear Facilities. D. A. Waite, Battelle, Pacific Northwest Laboratories, Richland, Washington; presented at Health Physics Society Annual Meeting, June 17, 1973, Miami, Florida.

BNWL-SA-4676. 1973. Analysis of an Analytical Technique for Distributing Air Sampling Locations Around Nuclear Facilities. D. A. Waite, Battelle, Pacific Northwest Laboratories, Richland, Washington; presented at the Third International Congress on International Radiation Protection Association, September 9 through 14, 1973 in Washington, D.C.; published as CONF-73090-P1, pp. 406-410.

10 CFR 830.120, Code of Federal Regulations, Title 10, Part 830, Chapter 120. Nuclear Safety Management, Quality Assurance Requirements.

40 CFR 61, Code of Federal Regulations, Title 40, Part 61. National Emission Standards for Hazardous Air Pollutants.

Comprehensive Environmental Response, Compensation, and Liability Act of 1980, as amended, Public Law 96-510, 94 Stat. 2767, 42 USC 9601 et seq.

DOE/EH-0173T. 1991. Environmental Regulatory Guide for Radiological Effluent Monitoring and Environmental Surveillance. Assistant Secretary for Environment, Safety and Health, U.S. Department of Energy, Washington, D.C.

DOE/EM-0327. 1997. Accelerating Cleanup: Focus on 2006, Discussion Draft. Office of Environmental Management, U.S. Department of Energy, Washington, D.C.

DOE Guide 1324.5B. "Implementation Guide for Records Management."

DOE Order 225.1. “Accident Investigations.”

DOE Order 231.1. "Environment, Safety, and Health Reporting." .

DOE Order 232.1. "Occurrence Reporting and Processing of Operations Information."

DOE Order 5400.1. "General Environmental Protection Program."

DOE Order 5400.5. "Radiation Protection of the Public and the Environment." 
DOE Order 5484.1. "Environmental Protection, Safety, and Health Protection Information Reporting Requirements."

DOE Order 5700.6B. "Quality Assurance."

DOE Order 5700.6C. "Quality Assurance."

DOE/RL-96-92. 1996. Hanford Strategic Plan. U.S. Department of Energy, Richland, Washington.

Ecology (State of Washington Department of Ecology), EPA (U.S. Environmental Protection Agency): and DOE (U.S. Department of Energy). 1989. Hanford Federal Facility Agreement and Consent Order Between the U.S. Environmental Protection Agency, the U.S. Department of Energy, and the State of Washington Department of Ecology, May 15, 1989, as amended. Olympia; Seattle, and Richland, Washington.

EGG-10617-1062. 1990. An Aerial Radiological Survey of the Hanford Site and Surrounding Area, Richland Washington - Date of Survey: July-August 1988. Remote Sensing Laboratory operated for DOE by EG\&G/EM, Idaho Falls, Idaho.

EML-587. 1997. Semi-Annual Report of the Department of Energy, Office of Environmental Management, Quality Assessment Program. C. G. Sanderson, and P. Greenlaw, Environmental Measurements Laboratory, U.S. Department of Energy, New York.

EPA-402-B-92-001. 1992. User's Guide for CAP88-PC, Version 1.0. B. S. Parks, Office of Radiation Programs, U.S. Environmental Protection Agency, Las Vegas, Nevada.

EPA-520/1-80-12. 1980. Upgrading Environmental Radiation Data: Health Physics Society Committee Report HPSR-1. Office of Radiation Programs, U.S. Environmental Protection Agency, Washington, D.C.

EPA-600/4-79-020. 1983. Methods for Chemical Analysis of Water and Wastes. U.S. Environmental Protection Agency, Cincinnati, Ohio.

EPA-600/4-81-004. 1981. Environmental Radioactivity Laboratory Intercomparison Studies Program: Fiscal Year 1980-81. A. B. Jarvis and L. Siu, U.S. Environmental Protection Agency, Las Vegas, Nevada.

EPA-600/4-82-055. 1982. Methods for Chemical Analysis of Water and Wastes. U.S. Environmental Protection Agency, Washington, D. C.

EPA-600/R-94-111. 1994. Methods for the Determination of Metals in Environmental Samples, Supplement I. U.S. Environmental Protection Agency, Washington, D.C.

EPA-821/R-96-005. 1996. Determination of Trace Elements in Ambient Waters by Inductively Coupled Plasma-Masss Spectrometry (Draft). U.S. Environmental Protection Agency, Washington, D.C.

EPA-821/R-96-006. 1996. Determination of Trace Elements in Ambient Waters by Stabilized Temperature Graphite Furnace Atomic Absorption (Draft). U.S. Environmental Protection Agency, Washington, D.C. 
HEDL. 1981. Chapter 18, FFTF Technical Specifications, FFTF Final Safety Analysis Report. Hanford Engineering Development Laboratory, Richland, Washington.

HNF-EP-0573-5. 1997. Hanford Site Near-Facility Environmental Monitoring Annual Report, Calendar Year 1996. C. J. Perkins, A. R. Johnson, B. M. Markes, S. M. McKinney, R. M. Mitchell, and R. K. Price, Fluor Daniel Hanford, Inc., Richland, Washington.

HW-69369. 1962. A Compilation of Basic Data Relating to the Columbia River Section 8 - Dispersion of Reactor Effluent in the Columbia River. J. K. Soldat, General Electric, Richland, Washington.

HW-80991. 1964. Evaluation of Radiological Conditions in the Vicinity of Hanford for 1963.

R. F. Foster and R. H. Wilson, U.S. Atomic Energy Commission, Washington, D.C.

International Commission on Radiological Protection. 1977. ICRP Publication 26, Recommendations of the International Commission on Radiological Protection. Annals of the ICRP, Vol. 1, No. 3, Pergamon Press, Elmsford, New York.

International Commission on Radiological Protection. 1979a. ICRP Publication 30, Part 1, Limits for Intakes of Radionuclides by Workers. Annals of the ICRP, Vol. 2, No. 3/4, Pergamon Press, Elmsford, New York.

International Commission on Radiological Protection. 1979b. ICRP Publication 30, Supplement to Part 1, Limits for Intakes of Radionuclides by Workers. Annals of the ICRP, Vol. 3, No. 1-4, Pergamon Press, Elmsford, New York.

International Commission on Radiological Protection. 1980. ICRP Publication 30, Part 2, Limits for Intakes of Radionuclides by Workers. Annals of the ICRP, Vol. 4, No. 3/4, Pergamon Press, Elmsford, New York.

International Commission on Radiological Protection. 1981a. ICRP Publication 30, Supplement to Part 2, Limits for Intakes of Radionuclides by Workers. Annals of the ICRP, Vol. 5, No. 1-6, Pergamon Press, Elmsford, New York.

International Commission on Radiological Protection. 1981b. ICRP Publication 30, Part 3 Including Addendum to Parts 1 and 2, Limits for Intakes of Radionuclides by Workers. Annals of the ICRP, Vol. 6, No. 2/3, Pergamon Press, Elmsford, New York.

International Commission on Radiological Protection. 1982a. ICRP Publication 30, Supplement $A$ to Part 3, Limits for Intakes of Radionuclides by Workers. Annals of the ICRP, Vol. 7, No. 1-3, Pergamon Press, Elsmford, New York.

International Commission on Radiological Protection. 1982b. ICRP Publication 30, Supplement B to Part 3 Including Addendum to Supplements to Parts 1 and 2, Limits for Intakes of Radionuclides by Workers. Annals of the ICRP, Vol. 8, No. 1-3, Pergamon Press, Elmsford, New York.

International Commission on Radiological Protection. 1988. ICRP Publication 30, Part 4, Limits for Intakes of Radionuclides by Workers: An Addendum. Annals of the ICRP, Vol. 19, No. 4, Pergamon Press, Elmsford, New York. 
PNL-3127. 1980. Radiological Survey of Exposed Shorelines and Islands of the Columbia River Between Vernita and the Snake River Confluence. M. J. Sula, Pacific Northwest Laboratory, Richland, Washington.

PNL-3777 Rev. 2. 1993. Recommended Environmental Dose Calculation Methods and HanfordSpecific Parameters. R. G. Schreckhise, K. Rhoads, J. S. Davis, B. A. Napier, and J. V. Ramsdell, Pacific Northwest Laboratory, Richland, Washington.

PNL-6464. 1988. Environmental Monitoring at Hanford for 1987. R. E. Jaquish and P. J. Mitchell, Pacific Northwest Laboratory, Richland, Washington.

PNL-6584. 1988. GENII - The Hanford Environmental Radiation Dosimetry Software System. B. A. Napier, R. A. Peloquin, D. L. Strenge, and J. V. Ramsdell, 3 volumes, Pacific Northwest Laboratory, Richland, Washington.

PNL-7124. 1989. The Determination of the Penetrating Radiation Dose at Hanford. L. A. Rathbun, Pacific Northwest Laboratory, Richland, Washington.

PNL-7803. 1991. Hanford Area 1990 Population and 50-Year Projections. D. M. Beck, B. A. Napier, M. J. Scott, A. G. Thurman, M. D. Davis, D. B. Pittenger, S. F. Shindle, and N. C. Batishko, Pacific Northwest Laboratory, Richland, Washington.

PNL-8150. 1992. Methods for Estimating Doses to Organisms from Radioactive Materials Released into the Aquatic Environment. D. A. Baker and J. K. Soldat, Pacific Northwest Laboratory, Richland, Washington.

PNL-8531. 1993. Columbia River Monitoring: Distribution of Tritium in Columbia River Water at the Richland Pumphouse. R. L. Dirkes, Pacific Northwest Laboratory, Richland, Washington.

PNL-8789. 1993. Investigation of Exposure Rates and Radionuclide and Trace Metal Distributions Along the Hanford Reach of the Columbia River. A. T. Cooper and R. K. Woodruff, Pacific Northwest Laboratory, Richland, Washington.

PNL-MA-580, Rev. 2. 1996. Surface Environmental Surveillance Procedures Manual. R. W. Hanf and R. L. Dirkes, eds., Pacific Northwest National Laboratory, Richland, Washington.

PNNL. 1997. "Subject Areas (Standards, Procedures and Guidelines), A-Manuals." In StandardsBased Management System [Online]. Available URL: http://wwwi.pnl.gov:2080/.

PNNL-6415 Rev. 9. 1997. Hanford Site National Environmental Policy Act (NEPA) Characterization. D. A. Neitzel (ed.), C. J. Fosmire, D. W. Harvey, D. J. Hoitink, D. A. Neitzel, P. D. Thorne, B. N. Bjornstad, R. A. Fowler, P. L. Hendrickson, D. J. Hostick, T. M. Poston, and M. K. Wright, Pacific Northwest National Laboratory, Richland, Washington.

PNNL-10714. 1995. Nonradiological Chemical Pathway Analysis and Identification of Chemicals of Concern for Environmental Monitoring at the Hanford Site. M. L. Blanton, A. T. Cooper, and K. J. Castleton, Pacific Northwest National Laboratory, Richland, Washington. 
PNNL-1 1464. 1997. Environmental Surveillance Master Sampling Schedule. L. E. Bisping, Pacific Northwest National Laboratory, Richland, Washington.

PNNL-1 1472. 1997. Hanford Site Environmental Report for Calendar Year 1996. R. L. Dirkes and R. W. Hanf (eds.), Pacific Northwest National Laboratory, Richland, Washington.

PNNL-11473. 1997. Hanford Site Environmental Data Report for Calendar Year 1996. Pacific Northwest National Laboratory, Richland, Washington.

SW-846. 1986. Test Methods for Evaluating Solid Wastes: Physical/Chemical Methods, 3rd ed. Office of Solid Waste and Emergency Response, U.S. Environmental Protection Agency, Washington, D.C.

Turner, B. D. 1970. Workbook of Atmospheric Dispersion Estimates. U.S. Environmental Protection Agency, Research Triangle Park, North Carolina.

WAC 173-201A, Washington Administrative Code. Water Quality Standards for Surface Waters of the State of Washington. Olympia, Washington. 


\title{
Hanford Site Environmental Monitoring Plan
}

\author{
Section III.B. Groundwater Monitoring
}

\begin{tabular}{|l|l|}
\hline Prepared by: Date: & Date: \\
P. D. Thorne, Pacific Northwest National \\
Laboratory
\end{tabular}




\section{Introduction}

Groundwater monitoring is a critical element of the U.S. Department of Energy's (DOE's) environmental monitoring program at the Hanford Site because an unconfined aquifer and a system of deeper confined aquifers underlie the site. Groundwater from the unconfined aquifer entering the Columbia River is a significant pathway for transport of contaminants.

Groundwater monitoring is conducted at the Hanford Site for a variety of purposes: near-field monitoring of specific facilities, sitewide monitoring of existing contaminant plumes, and monitoring to assess the effectiveness of groundwater-remediation activities. Because the Hanford Site has multiple, extensive, and unique groundwater-pollution problems, DOE has established an integrated groundwatermonitoring project to ensure protection of the public and the environment while improving the efficiency of monitoring operations.

\section{Regulatory Drivers}

The regulatory framework governing groundwater monitoring at the Hanford Site consists of integrated federal and state regulations, orders, and agreements. DOE Order 5400.1 establishes a groundwatermonitoring program that meets the requirements of DOE Order 5400.5, which deals with radiation protection of the public and the environment, and other applicable federal and state regulations. According to DOE Order 5400.1, groundwater-monitoring programs shall be conducted onsite and in the vicinity of DOE facilities for the following purposes:

- obtaining data for determining baseline conditions of groundwater quality and quantity

- demonstrating compliance with and implementation of all applicable regulations and DOE Orders

- providing data to permit the early detection of groundwater pollution or contamination

- identifying existing and potential groundwater-contamination sources and maintaining surveillance of these sources

- providing a reporting mechanism for detected groundwater pollution or contamination

- providing data on which decisions can be made concerning land-disposal practices and the management and protection of groundwater resources.

DOE Order 5400.1 also stipulates that, where applicable, groundwater monitoring around facilities be designed and implemented in accordance with regulations in Title 40, Code of Federal Regulations, Part 264 (40 CFR 264) or 265, Subpart F (pursuant to the Resource Conservation and Recovery Act of 1976 [RCRA]). DOE Order 5820.2A, which deals with radioactive waste management, also requires groundwater monitoring; specifically, a system of groundwater- or vadose zone-monitoring wells meeting RCRA requirements ( 40 CFR 264) shall be installed, as a minimum, around clusters of liquid wastestorage tanks. DOE Order 5820.2A also stipulates that groundwater be monitored around low-level waste facilities. 
RCRA establishes regulatory standards for the generation, transportation, storage, treatment, and disposal of hazardous waste and applies to active waste-management facilities and facilities undergoing closure. As authorized by the U.S. Environmental Protection Agency (EPA), State of Washington regulations Washington Administrative Code (WAC) 173-303 implement RCRA groundwater requirements in lieu of the federal regulations. WAC 173-304, which deals with solid waste, and WAC 173-216, which deals with permitted liquid discharges, also contain groundwater-protection and -monitoring requirements that apply to activities at the Hanford Site. RCRA corrective action requirements apply to inactive sites that have received RCRA permits. The Comprehensive Environmental Response, Compensation, and Liability Act of 1980 (CERCLA) and the Superfund Amendments and Reauthorization Act of 1986 (SARA), which are implemented through EPA regulations in 40 CFR 300, establish groundwatermonitoring requirements for other inactive "past-practice" waste sites. Under these laws, three areas of the Hanford Site (100, 200, and 300 Areas) are currently listed on the National Priorities List (40 CFR 300 Appendix B).

To coordinate the actions of various regulatory authorities and provide a strategy for achieving regulatory compliance and waste-site cleanup, the Hanford Federal Facility Agreement and Consent Order (also known as the Tri-Party Agreement) (Ecology et al. 1989) was established. This agreement between DOE, EPA, and the State of Washington Department of Ecology (Ecology) provides for the interface of overlapping regulatory programs. The agreement specifies that both active and inactive treatment, storage, or disposal (TSD) units that have received RCRA permits will be managed and closed under RCRA regulations, including groundwater-monitoring requirements. Other past-practice waste sites will be addressed under CERCLA regulations. Contaminated groundwater will be addressed as a CERCLA source of contamination. However, all CERCLA actions will meet RCRA corrective action standards under the agreement. In addition, CERCLA remedial actions at groundwater operable units designated as RCRA past-practice units will be incorporated into the Hanford Facility RCRA Permit (Ecology 1994). Under criteria established in the Tri-Party Agreement, a "lead regulatory agency" is designated for each operable unit to avoid inconsistency and duplication of effort.

\section{Project Management and Objectives}

In the past, groundwater programs were independently developed to address the needs of various programs, including CERCLA, RCRA, WAC 173-216, operational monitoring, and sitewide environmental surveillance (DOE Order 5400.1). Because of increasing groundwater program overlap, regulatory complexity, and conflicting management issues, DOE recognized the need for a more effective, consistent, and objective project. Therefore, in 1996, DOE directed its contractors to integrate the various groundwater programs into one consolidated project. The Groundwater Monitoring Project is designed to address all groundwater-monitoring needs at the site, eliminate regulatory program redundancy, and establish a cost-effective hierarchy for groundwater-monitoring activities. Specific objectives of the Groundwater Monitoring Project are the following:

- maintaining and verifying compliance with all applicable groundwater regulations

- characterizing and defining hydrogeologic, physical, and chemical trends in the groundwater system

- establishing baselines of groundwater quality

- providing continuing, independent assessment of groundwater-remediation activities

- identifying and quantifying new or existing groundwater problems.

The Hanford Site groundwater-protection management plan (DOE/RL-89-12, Rev. 2) summarizes groundwater-protection policies, project-integration activities, program scope, and responsibilities. The 
groundwater-protection management plan includes near-field monitoring at RCRA and other facilities, sitewide and offsite monitoring of groundwater-contaminant migration conducted under the environmental surveillance program, and monitoring conducted to support groundwater-remediation projects under CERCLA or RCRA corrective actions.

The Groundwater Monitoring Project is managed by Pacific Northwest National Laboratory (PNNL) in accordance with an established quality assurance plan, which conforms to the requirements of 10 CFR 830.120 as interpreted and implemented by the Standards-Based Management System (PNNL 1997).

Monitoring-well networks are located and constructed based on data quality objectives and/or criteria established in site-specific or regional monitoring plans. Groundwater monitoring at RCRA TSD units is conducted in accordance with site-specific groundwater-monitoring plans prepared and maintained by PNNL that conform to RCRA regulatory requirements. A project scientist is assigned to each site or logical grouping of sites and is responsible for ensuring execution of the plan. RCRA corrective action and CERCLA past-practice groundwater-monitoring requirements are documented in interim and final records of decision (RODs) and implementing plans. As required by DOE Orders, additional wells across the Hanford Site are sampled to monitor movement of existing contaminant plumes and to determine the impact of facilities not specifically addressed by other regulations. These wells comprise the sitewide environmental surveillance network.

\section{General Groundwater-Monitoring Information}

This section provides general information for all Hanford Site groundwater-monitoring activities performed by the Groundwater Monitoring Project regardless of the specific purpose or regulatory . driver. This is followed by sections with information that is applicable to RCRA groundwater monitoring, monitoring to support CERCLA and RCRA corrective actions, and sitewide environmental surveillance monitoring of groundwater.

\section{Construction and Maintenance of Wells}

Both older wells and newer wells built to WAC 173-160 standards are used by the Groundwater Monitoring Project. Most older monitoring wells on the Hanford Site are 10,15, or $20 \mathrm{~cm}$ in diameter and are constructed of carbon-steel casing. A number of newer wells are constructed of 10-cm stainlesssteel casing. Most unconfined aquifer wells are completed with well screens or perforations in the upper 3 to $6 \mathrm{~m}$ of the aquifer.

For older existing wells, a fitness-for-use evaluation is conducted, and appropriate limitations are designated. Wells with limitations are sampled for a limited set of constituents or are used only for water-level measurements.

New wells are installed so as to maintain the integrity of the monitoring well borehole and prevent crosscontamination from the surface or other zones into the aquifer. The well casing isolates the sampled interval of the well from the vadose zone and nonsampled intervals of the aquifer. Screens are used to filter out solids and enhance collection of representative groundwater samples from the aquifer. All new wells meet the requirements of WAC 173-160. Groundwater-monitoring wells are located, designed, and constructed based on data quality objectives and criteria established in groundwatermonitoring plans. 
Groundwater-monitoring wells require periodic maintenance to ensure that representative samples are obtained. Wells are typically scheduled for routine inspection and maintenance every 3 to 5 yr. Where a dedicated pump is installed, the pump is inspected and tested. A downhole video survey is then performed to verify integrity of the casing. The inside of the casing is usually brushed to remove deposits before replacing the pump. Nonroutine well maintenance may be scheduled when a problem is identified during sampling.

\section{Hydrologic Characterization and Modeling}

Hydrologic characterization activities are conducted to gain understanding of hydrogeologic conditions and controls on groundwater and contaminant movement. Characterization activities include geologic sampling, geophysical logging of boreholes, and hydraulic and tracer testing of wells to determine aquifer-flow and -transport properties. These activities are directed toward developing site-specific and regional hydrogeologic models of the Hanford Site. A three-dimensional, multilayer, numerical, groundwater model of the unconfined aquifer has been constructed in conjunction with characterization. The model is used to predict the movement of groundwater and contaminants under present and future Hanford Site conditions. The model is also used to help determine impacts on the monitoring network. and the best location for monitoring wells as Hanford Site activities and groundwater conditions change. Other modeling activities support groundwater-remediation and waste-management activities.

\section{Water-Level Monitoring}

Water-level monitoring is performed to help characterize the direction and velocity of groundwater flow, to determine the impact of Hanford Site operations on the groundwater-flow system, and to assess the adequacy of point-of-compliance wells to detect groundwater impacts from specific monitored facilities. Routine water-level measurements in the unconfined aquifer are made annually to construct a sitewide water-table map and to determine flow directions in the vicinity of facilities that require groundwater monitoring. Water-table maps are published in the annual groundwater-monitoring report (e.g., PNNL-11470). The sitewide water-level information for the unconfined aquifer is used for the following:

- identification of recharge and discharge areas

- evaluation of physical influence of wastewater discharges on groundwater-flow directions

- determination of potential for water movement between adjacent groundwater and surface-water bodies

- determination of horizontal hydraulic gradient, which is needed to estimate the average linear velocity of groundwater flow and contaminant migration

- improvement of design of the water-level monitoring-well network

- maintenance of knowledge of groundwater-flow conditions at the site

- calibration of and verification of numerical groundwater-flow models. 
The distribution of hydraulic head in the upper basalt-confined aquifer system is also monitored to assess the potential for contaminants to migrate off the Hanford Site through this aquifer and to evaluate the hydraulic relationship between the unconfined aquifer and upper basalt-confined aquifer systems.

In addition to the annual regional water-level measurements, site-specific measurements are also collected. The frequency of site-specific water-level measurements is determined by a variety of factors. Annual, semiannual, or quarterly monitoring is conducted for most wells. Near-continuous water-level monitoring is maintained in areas likely to experience rapid or significant changes in the water table. These areas are generally located near known recharge or discharge sources (e.g., waste-disposal facilities, public water-supply wells, and wells near the Columbia River). Water levels are measured routinely in wells before any groundwater sampling is performed.

\section{Groundwater Sampling and Analysis}

Wells to be sampled each year by the Groundwater Monitoring Project will be documented in a separately published sampling schedule (i.e., PNNL-11464). The distribution of wells sampled during fiscal year 1996 is shown in Figures III.B-1 and III.B-2. This distribution is expected to change slightly from year to year, depending on changing groundwater conditions and project requirements.

Groundwater-sampling and associated quality control (QC) procedures are administered by PNNL through annual statements of work (SOWs) to other contractors. The SOWs specify wells to be sampled, analytes, sampling frequencies, quality requirements, analytical and sampling procedures, and reporting requirements. Analysis of groundwater samples is managed by Waste Management Federal Services of Hanford, Inc. through SOWs to commercial analytical laboratories. These SOWs specify analytical and $\mathrm{QC}$ procedures and reporting requirements pertaining to sample analysis.

The Groundwater Monitoring Project operates in accordance with a quality assurance plan that defines the controls, procedures, and documentation that are required. That plan implements the requirements of 10 CFR 830.120. Trained staff members collect samples according to written procedures. Samples are analyzed according to documented standard analytical procedures (e.g., SW-846). The quality of analytical data is verified by a continuing program of internal laboratory QC, which consists of participation in interlaboratory crosschecks, replicate sampling and analysis, submittal of blind standard samples and blanks, and splitting samples with other laboratories. Letters of instruction are prepared as needed to meet specific program requirements.

Data Quality Objectives. Data quality objectives are defined in the QC plan, an appendix of the quality assurance plan. As specified in the SOW for sampling and analysis, all groundwater monitoring is covered by the same set of quality procedures.

Five basic data quality criteria are applied: precision, accuracy, representativeness, completeness, and comparability, along with applicable project-specific quality parameters to evaluate the data and the laboratories analyzing the samples. Evaluation of the sampling and analysis results with respect to the five basic data quality criteria are summarized below.

- Precision is evaluated using data results from laboratory duplicates, matrix spike duplicates, field duplicates, and blind samples. 


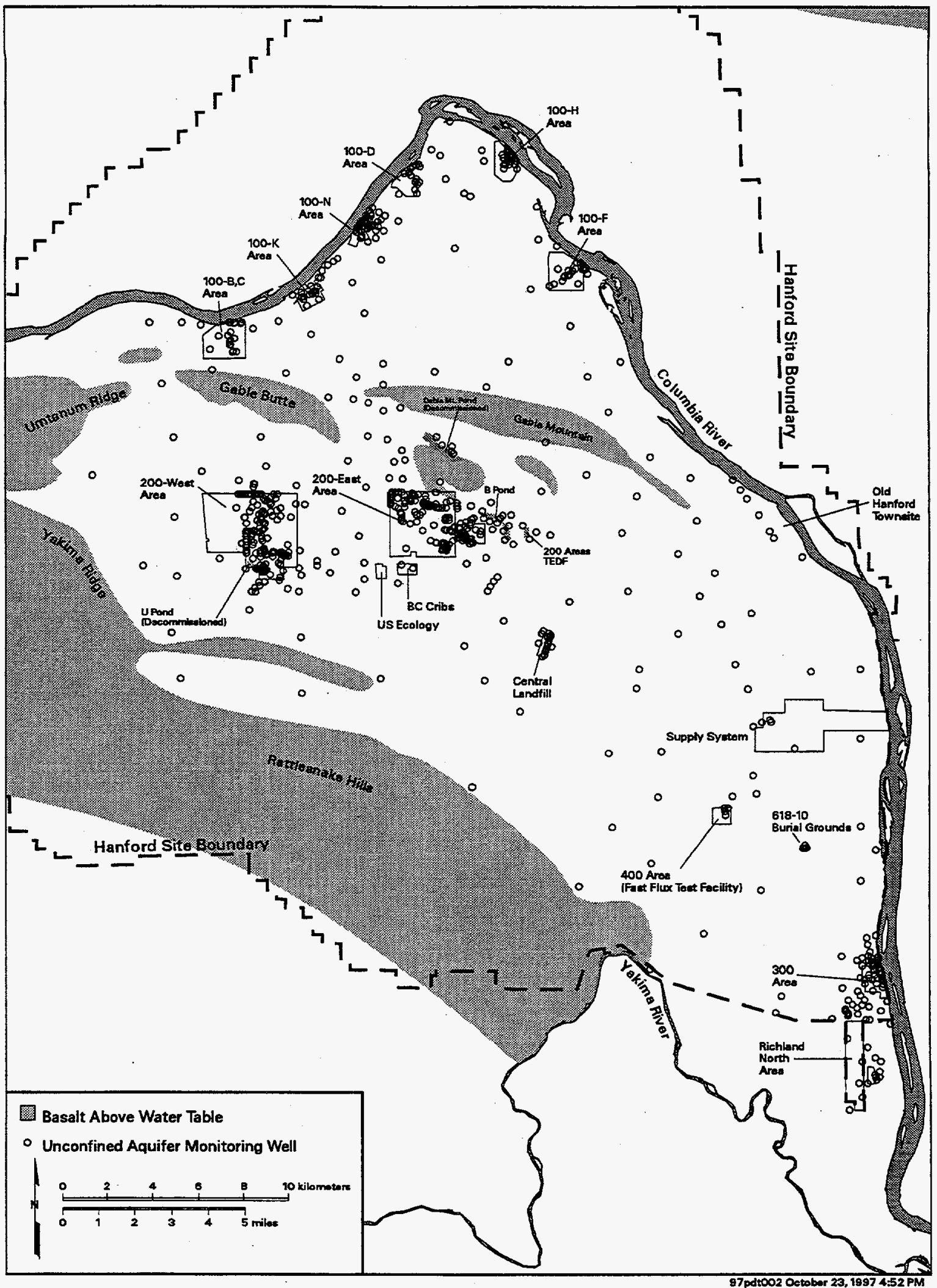

Figure III.B-1. Unconfined Aquifer-Monitoring Wells Sampled in Fiscal Year 1996 


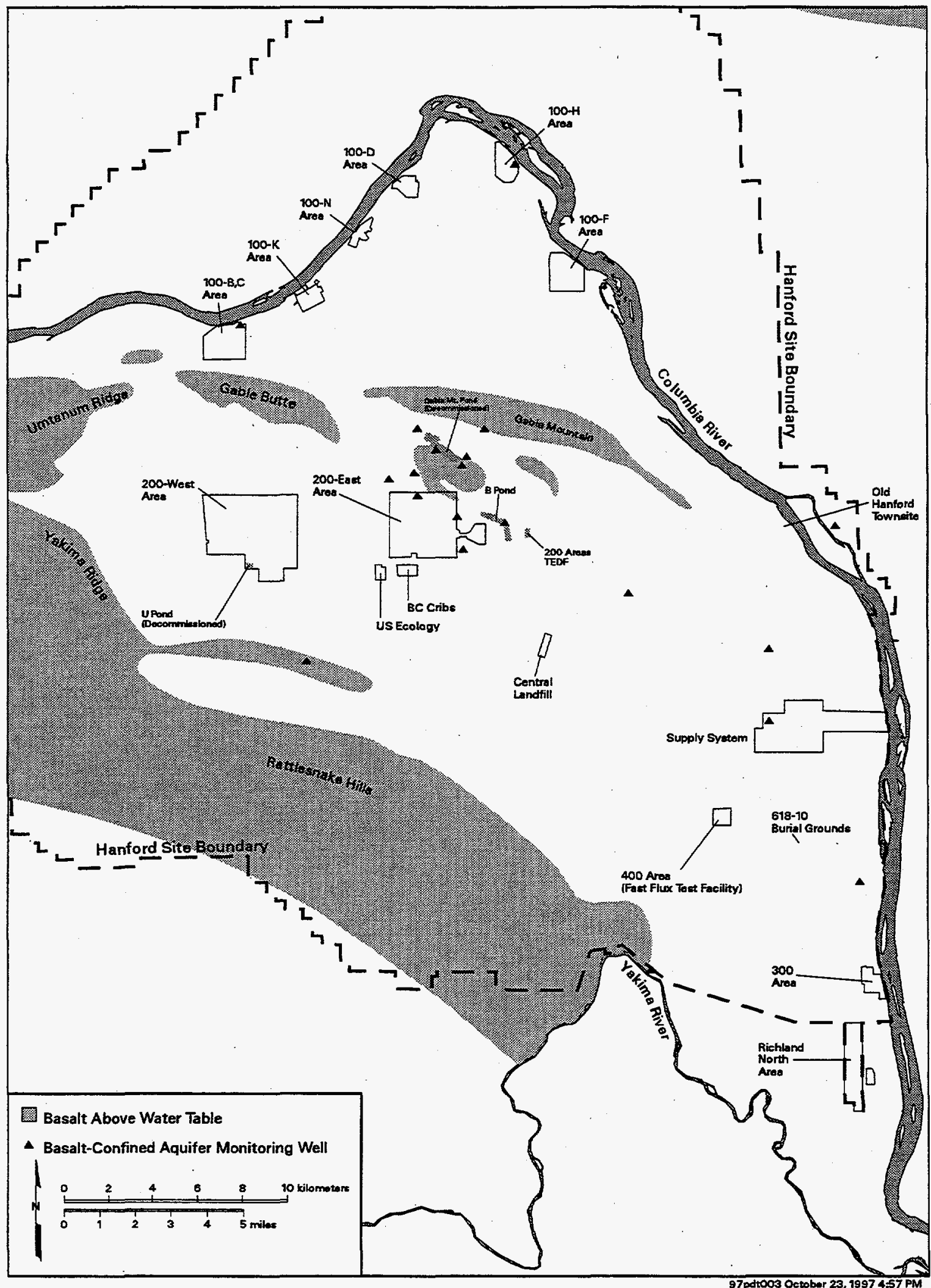

Figure III.B-2. Basalt-Confined Aquifer-Monitoring Wells Sampled in Fiscal Year 1996 
- Accuracy is evaluated using data results from laboratory matrix spikes; laboratory control samples; EPA water-pollution, water-supply, and interlaboratory-performance-evaluation programs; and blind samples.

- Representativeness expresses the degree to which facility groundwater-monitoring data represent the real composition of the groundwater in the aquifer. Goals for data representativeness for groundwatermonitoring programs are addressed qualitatively by the specification of well construction, sampling locations, sampling intervals, and sampling and analysis techniques identified in the groundwatermonitoring plan for each RCRA facility.

- Completeness is defined as the percentage of measurements made that are judged to be valid. Completeness is determined by the number of data not flagged as invalid divided by the total number of data validated multiplied by 100 . The calculated percentages used in reporting completeness are conservative figures and are based on data flags. For each method, the percent complete each quarter should be at least $90 \%$.

- Comparability is used to ensure that samples analyzed by different laboratories or by the same laboratory over different time periods are comparable. Samples are analyzed in accordance with SW- $\$ 46$ and other applicable approved methods. Comparability of field measurements is determined by following approved sampling procedures that ensure consistency among sampling events.

Limits for reporting, precision, accuracy, and completeness are presented in the QC plan. Sitespecific groundwater-monitoring or -assessment plans specify whether a particular site has more stringent data quality objectives than those specified in the QC plan.

Objectives for precision and accuracy for chemical analyses are based on criteria stipulated in the methodology (e.g., SW-846, EPA-600/4-79-020). Guidelines for precision and accuracy for chemical $\mathrm{QC}$ data are provided in the QC plan.

Detection limits for chemical and radiological constituents are defined in the laboratory contract. For radiological constituents, reporting limits as low as 1/3 the derived 4-mrem 1-yr effective dose equivalent are preferred but are not always achievable. Preferred reporting limits and actual reporting: limits for radiological constituents are listed in the QC plan. For chemical constituents, detection limits as low as $1 / 3$ of the EPA primary drinking water standards are preferred. In some cases, detection limits that are $1 / 3$ of drinking water standards are not feasible (e.g., pentachlorophenol and cadmium). Because detection limits change frequently, these values are not provided in the QC plan.

QC Program. The QC program helps to ensure the reliability and validity of field and laboratory measurements conducted in support of the Groundwater Monitoring Project. QC practices are defined in the QC plan for the project. Field and laboratory QC components and reporting requirements are included in the plan. Laboratory QC includes analysis of method blanks, matrix spikes, matrix duplicates, matrix spike duplicates, surrogate spikes, and laboratory-control samples. Blind standards are also forwarded to the laboratory each quarter. The results from field and laboratory QC samples are evaluated to determine whether the contracted laboratories are performing satisfactorily.

\section{Data Management and Interpretation}

Groundwater data are managed using computer databases and hard-copy files. Water-level and analytical data are currently stored in the Hanford Environmental Information System (HEIS) computer 
database. Well logs, effluent data, hydraulic parameters, field/sampling records, hard-copy analytical results, and other related information are assembled and stored in project files by the contractors responsible for the work.

Data from wells that monitor waste-disposal facilities are reviewed for compliance with applicable internal guidelines and state and federal regulations. If monitoring indicates that a facility is out of compliance, or that groundwater is being impacted, an investigation is initiated to determine the causes and evaluate remedial actions. The details of these types of investigations are discussed in later sections on facility-specific monitoring.

Interpretation activities include observing trends in contaminant concentrations of individual wells, mapping contaminant plumes, determining groundwater-flow directions, computing aquifer properties such as hydraulic conductivity, compiling effluent-source information, and modeling the groundwater system to make predictions. Interpretation results are documented in the annual groundwater-monitoring report (e.g., PNNL-11470) and in other topical reports.

\section{Groundwater-Monitoring Reports}

All Hanford Site groundwater-monitoring activities are summarized in a comprehensive annual groundwater-monitoring report (e.g., PNNL-11470). That report discusses groundwater-chemistry results and suspected sources of groundwater contaminants. Maps are provided for most of the groundwatercontaminant plumes. Water-table maps for the unconfined and upper basalt-confined aquifer systems and a discussion of site hydrogeology are also provided. Data are tabulated and included in an electronic format. A summary description of the QC program for sample analysis and a summary of the fiscal year's activities, together with the required statistical evaluations, are appended to the report.

Results of operational and RCRA TSD monitoring are also included in the groundwater annual report. RCRA regulations require that measured constituent concentrations and any changes in parameters for each groundwater-monitoring well must be reported. Any significant differences from the initial background levels found in the upgradient well(s) are separately identified in the annual report (e.g., PNNL-11470). In addition to the annual report, quarterly RCRA letter reports, summarizing major findings for that quarter, are prepared and submitted to Ecology. A list of the quarterly reports is included in each annual report for the respective report year. The quarterly reports consist of regulatory notification letters that indicate that the data have been validated and made available electronically. The annual report provides an interpretive analysis of all the available data. For assessment-level RCRA monitoring, a report of the results of the groundwater quality assessment program must be submitted annually. This may be included in the annual groundwater report or issued as a separate report.

The annual report (e.g., PNNL-11470) also summarizes groundwater-monitoring activities at the Solid Waste Landfill as required by WAC 173-304. Special project reports are issued periodically that include groundwater impact assessments (e.g., WHC-SD-EN-EV-008), data evaluation reports, journal articles, and presentations.

\section{RCRA and Operational Groundwater Monitoring}

The primary purposes of RCRA and operational groundwater monitoring are 1) to comply with the intent of state and federal RCRA requirements, 2) to assess potential impact on groundwater quality, and 3 ) to provide an early warning of unexpected occurrences and trends. Ecology and EPA issued the 
Hanford Facility RCRA Part B Permit in September 1994 (Ecology 1994). In the permit, Ecology and EPA designated the Hanford Site as a single RCRA facility with over 60 individual liquid and solid waste TSD units. The Tri-Party Agreement (Ecology et al. 1989) recognized that all of the TSD units cannot be permitted simultaneously and set up a schedule for submitting unit-specific Part B RCRA/ dangerous waste permit applications and closure plans to Ecology and EPA. Of the 60 TSD units, 26 require groundwater monitoring to determine if operations are impacting the uppermost aquifer. The locations of these RCRA TSD units are shown in Figure III.B-3.

RCRA groundwater-monitoring requirements fall under one of two categories: interim status or final status. A permitted (Part B) or closed RCRA TSD unit requires final-status groundwater monitoring as specified in 40 CFR 264 and WAC 173-303-645. RCRA TSD units without completed Part B permits or closure plans require interim-status groundwater monitoring as specified in 40 CFR 265 and WAC 173-303-400. Table III.B-1 lists the RCRA facilities requiring groundwater monitoring and the status of the each unit as of October $1,1997$.

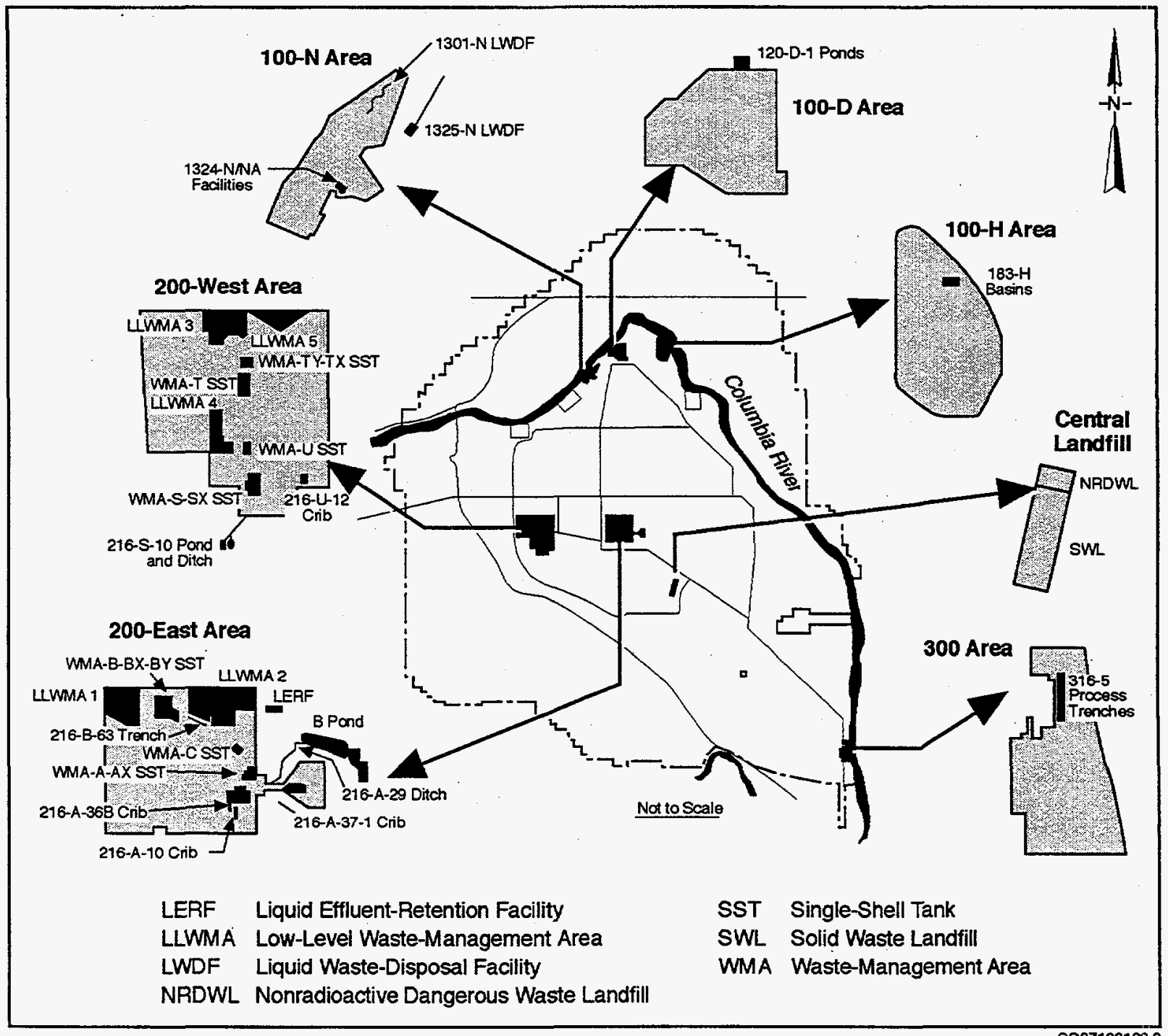

Figure II.B-3. Hanford Site RCRA Facilities Requiring Groundwater Monitoring 
Table III.B-1. Hanford Site Interim- and Final-Status Groundwater-Monitoring Projects (as of October 1, 1997)

\begin{tabular}{|c|c|c|c|c|c|c|}
\hline \multirow[b]{2}{*}{$\begin{array}{l}\text { TSD Unit, Date } \\
\text { Initiated }\end{array}$} & \multicolumn{2}{|c|}{$\begin{array}{c}\text { Interim-Status TSD Unit Groundwater } \\
\text { Monitoring } \\
\end{array}$} & \multicolumn{2}{|c|}{$\begin{array}{c}\text { Final-Status TSD Unit } \\
\text { Groundwater Monitoring } \\
\end{array}$} & \multirow[b]{2}{*}{$\begin{array}{c}\text { Associated } \\
\text { (CERCLA) } \\
\text { Groundwater } \\
\text { Operable Units } \\
\end{array}$} & \multirow[b]{2}{*}{$\begin{array}{c}\text { Year } \\
\text { Scheduled for } \\
\text { Part B or } \\
\text { Closure } \\
\end{array}$} \\
\hline & $\begin{array}{c}\text { Indicator } \\
\text { Parameter }^{(2)} \\
\text { Evaluation }^{(2)}\end{array}$ & $\begin{array}{c}\text { Groundwater } \\
\text { Quality } \\
\text { Assessment, Date } \\
\text { Initiated } \\
\end{array}$ & $\begin{array}{l}\text { Detection } \\
\text { Evaluation } \\
\end{array}$ & $\begin{array}{l}\text { Compliance } \\
\text { Evaluation }\end{array}$ & & \\
\hline $\begin{array}{l}\text { 120-D-1 Ponds, } \\
\text { April } 1992\end{array}$ & $\mathrm{x}$ & & & & 100-HR-3 & $1998^{(0)}$ \\
\hline $\begin{array}{l}\text { 183-H Solar } \\
\text { Evaporation } \\
\text { Basins, June } 1985\end{array}$ & & & & $\mathrm{x}$ & $100-\mathrm{HR}-3$ & $1994^{(b)}$ \\
\hline $\begin{array}{l}\text { 1301-N LWDF, } \\
\text { December } 1987\end{array}$ & $\mathrm{X}$ & & & & $100-N R-2$ & $1999^{(b)}$ \\
\hline $\begin{array}{l}\text { 1324-N/NA Pond, } \\
\text { December } 1987\end{array}$ & $\mathrm{x}$ & & & & $100-N R-2$ & $1998^{(b)}$ \\
\hline $\begin{array}{l}\text { 1325-N LWDF, } \\
\text { December } 1987\end{array}$ & $\mathrm{X}$ & & & & $100-N R-2$ & $1999^{(0)}$ \\
\hline $\begin{array}{l}\text { 216-B-3 Pond, } \\
\text { November } 1988\end{array}$ & $\mathrm{X}$ & & & & 200-PO-1 & $2000^{(6)}$ \\
\hline $\begin{array}{l}\text { 216-A-29 Ditch, } \\
\text { November } 1988\end{array}$ & $\mathrm{X}$ & $\cdot$ & & & 200-PO-1 & $2000^{(6)}$ \\
\hline $\begin{array}{l}\text { 216-A-10 Crib, }{ }^{(c)} \\
\text { November } 1988\end{array}$ & $\mathrm{X}$ & $X, 1997$ & & & $200-\mathrm{PO}-1$ & $>2000^{(b)}$ \\
\hline $\begin{array}{l}\text { 216-A-36B Crib, }{ }^{(c)} \\
\text { May } 1988\end{array}$ & $\mathrm{X}$ & $\mathrm{X}, 1997$ & & & $200-\mathrm{PO}-1$ & $>2000^{(b)}$ \\
\hline $\begin{array}{l}216-\mathrm{A}-37-1 \mathrm{Crib}^{(c)} \\
1997\end{array}$ & & $X, 1997$ & & & $200-\mathrm{PO}-1$ & $>2000^{(b)}$ \\
\hline $\begin{array}{l}\text { 216-B-63 Trench, } \\
\text { August } 1991\end{array}$ & $\mathrm{X}$ & & & & $200-\mathrm{PO}-1$ & $2000^{(b)}$ \\
\hline $\begin{array}{l}\text { 216-S-10 Pond, } \\
\text { August } 1991\end{array}$ & $\mathrm{x}$ & & & & & $>2000^{(b)}$ \\
\hline $\begin{array}{l}\text { 216-U-12 Crib, } \\
\text { September } 1991\end{array}$ & & $\mathrm{X}, 1993$ & & & 200-UP-1 & $>2000^{(b)}$ \\
\hline LERF, July 1991 & $\mathrm{X}$ & & & & & $1997^{(\mathrm{d})}$ \\
\hline $\begin{array}{l}\text { LLBG WMA-1, } \\
\text { September } 1988\end{array}$ & $\mathrm{x}$ & & & & & $1997^{(\mathrm{d})}$ \\
\hline $\begin{array}{l}\text { LLBG WMA-2, } \\
\text { September } 1988\end{array}$ & $\mathrm{X}$ & & & & & $1997^{(\mathrm{d})}$ \\
\hline $\begin{array}{l}\text { LLBG WMA-3, } \\
\text { October } 1988\end{array}$ & $\mathrm{X}$ & & & & & $1997^{(\mathrm{d})}$ \\
\hline $\begin{array}{l}\text { LLBG WMA-4, } \\
\text { October } 1988\end{array}$ & $\mathrm{x}$ & & & & $200-Z P-1$ & $1997^{(\mathrm{d})}$ \\
\hline $\begin{array}{l}\text { LLBG WMA-5, } \\
\text { March } 1992\end{array}$ & $\begin{array}{c}\text { Discontinued in } \\
1995\end{array}$ & & & & & $1997^{(\mathrm{d})}$ \\
\hline
\end{tabular}


Table III.B-1. (contd)

\begin{tabular}{|c|c|c|c|c|c|c|}
\hline \multirow[b]{2}{*}{$\begin{array}{l}\text { TSD Unit, Date } \\
\text { Initiated }\end{array}$} & \multicolumn{2}{|c|}{$\begin{array}{c}\text { Interim-Status TSD Unit Groundwater } \\
\text { Monitoring }\end{array}$} & \multicolumn{2}{|c|}{$\begin{array}{l}\text { Final-Status TSD Unit } \\
\text { Groundwater Monitoring }\end{array}$} & \multirow[b]{2}{*}{$\begin{array}{c}\text { Associated } \\
\text { (CERCLA) } \\
\text { Groundwater } \\
\text { Operable Units }\end{array}$} & \multirow[b]{2}{*}{$\begin{array}{c}\text { Year } \\
\text { Scheduled for } \\
\text { Part B or } \\
\text { Closure }\end{array}$} \\
\hline & $\begin{array}{c}\text { Indicator } \\
\text { Parameter } \\
\text { Evaluation }^{(2)}\end{array}$ & $\begin{array}{c}\text { Groundwater } \\
\text { Quality } \\
\text { Assessment, Date } \\
\text { Initiated } \\
\end{array}$ & $\begin{array}{c}\text { Detection } \\
\text { Evaluation } \\
\end{array}$ & $\begin{array}{c}\text { Compliance } \\
\text { Evaluation } \\
\end{array}$ & & \\
\hline $\begin{array}{l}\text { WMA-A-AX SST, } \\
\text { February } 1990\end{array}$ & $\mathrm{x}$ & & & & & $>2000^{(0)}$ \\
\hline $\begin{array}{l}\text { WMA-B-BX-BY } \\
\text { SST, February } \\
1990\end{array}$ & & X, 1996 & & & & $>2000^{(b)}$ \\
\hline $\begin{array}{l}\text { WMA-C SST, } \\
\text { February } 1990\end{array}$ & $\mathrm{X}$ & . & & & 200-PO-1 & $>2000^{(b)}$ \\
\hline $\begin{array}{l}\text { WMA-S-SX SST, } \\
\text { October } 1991\end{array}$ & & $\mathrm{X}, 1995$ & & & 200-UP-1 & $>2000^{(b)}$ \\
\hline $\begin{array}{l}\text { WMA-T SST, } \\
\text { February } 1990\end{array}$ & & X, 1993 & & & $200-Z P-1$ & $>2000^{(b)}$ \\
\hline $\begin{array}{l}\text { WMA-TX-TY } \\
\text { SST, September- } \\
\text { October } 1991\end{array}$ & & $\mathrm{X}, 1993$ & & & $200-Z P-1$ & $>2000^{(b)}$ \\
\hline $\begin{array}{l}\text { WMA-U SST, } \\
\text { October } 1990\end{array}$ & $\mathrm{X}$ & & & & $200-\mathrm{ZP}-1$ & $>2000^{(\mathrm{b})}$ \\
\hline $\begin{array}{l}316-5 \text { Area } \\
\text { Process } \\
\text { Trenches }{ }^{(e)} \text {, June } \\
1985\end{array}$ & & $\mathrm{x}$ & & $\begin{array}{l}X(1996 \text { to } \\
\text { final status })\end{array}$ & $300-F F-5$ & $1996^{(\mathrm{b})}$ \\
\hline $\begin{array}{l}\text { NRDWL, October } \\
1986\end{array}$ & $\mathrm{X}$ & & & & $200-\mathrm{PO}-1$ & $>2000^{(b)}$ \\
\hline
\end{tabular}

(a) Specific parameters ( $\mathrm{pH}$, specific conductance, total organic carbon, and total organic halogen) used to determine if a facility is affecting groundwater quality. Exceeding the established limits means that additional evaluation and sampling are required (groundwater quality assessment). An X in the column indicates whether an evaluation was needed or an assessment was required.

(b) Closure/postclosure plan; TSD unit will close under final status.

(c) 216-A-10, 216-A-36B, and 216-A-37-1 Cribs will be combined in fiscal year 1997 into one RCRA monitoring unit. RCRA monitoring will be performed according to interim-status groundwater quality assessment requirements.

(d) Part B permit; TSD unit will operate under final-status regulations beginning in year indicated.

(e) At the end of calendar year 1996, these will move from an interim-status assessment-monitoring evaluation (required by regulatory consent agreement and compliance order [Ecology and EPA 1986]) to a final-status compliance-monitoring evaluation.

CERCLA = Comprehensive Environmental Response, Compensation, and Liability Act of 1980.

LERF = liquid effluent retention facility.

LLBG = low-level burial ground.

LWDF = liquid waste-disposal facility.

NRDWL = Nonradioactive Dangerous Waste Landfill.

RCRA = Resource Conservation and Recovery Act of 1976.

SST $\quad=$ single-shell tanks.

TSD = treatment, storage, or disposal.

WMA = waste-management area.

$>\quad=$ Beyond the year 2000 . 
In addition to RCRA facilities, there are non-RCRA operational facilities on the Hanford Site that are regulated under the requirements of DOE Orders, State of Washington regulations, and the Tri-Party Agreement. Many of these are disposal facilities that receive treated effluents derived from liquid wastes associated with nuclear material processing, refining, and waste-treatment activities. All major discharges of untreated wastewater were terminated in June 1995. In December 1991, an agreement was reached to include all miscellaneous waste streams and/or any new waste-stream discharges to the ground under the waste-discharge permit system defined in WAC 173-216. Groundwater monitoring is conducted at three of these sites: 400 Area Process Pond, 200 Areas Treated Effluent Disposal Facility, and 200 Areas Effluent Treatment Facility disposal site. The Solid Waste Landfill is another non-RCRA facility that requires groundwater monitoring. This disposal facility is not addressed under the Tri-Party Agreement. Current operations and groundwater-monitoring activities conducted at the Solid Waste Landfill are regulated by WAC 173-304-490. Current groundwater-monitoring plans for these four facilities will be referenced in the annual groundwater-monitoring report (e.g., PNNL-11470).

\section{RCRA Interim Status}

Interim-status RCRA facilities are monitored under one of three phases: background monitoring phase, indicator parameter-evaluation phase, or groundwater quality assessment phase. A groundwatermonitoring plan for each RCRA facility describes the monitoring network, sampling and analysis procedures, analytes, and sampling frequency.

As specified in 40 CFR 265, groundwater samples from all RCRA monitoring wells must be obtained and analyzed quarterly for $1 \mathrm{yr}$ to establish background concentrations for future data comparisons. Sitespecific analytes (including radionuclides) are determined from evaluation of the waste stream or source associated with the facility. Additional site-specific constituents may be included to aid in tracking groundwater movement and the influence of other facilities. In some cases, the list of constituents from 40 CFR 264 Appendix IX is analyzed to establish a baseline for future comparisons. All of the RCRA facilities have completed their initial background monitoring phases.

After background levels of groundwater constituents are established, the indicator parameterevaluation program commences. Samples are collected semiannually to determine whether groundwater contamination from the facility is present. Sample data are compared with background data for selected indicator parameters. If a statistically significant change over background has occurred in a downgradient well, Ecology must be notified and a groundwater quality assessment-monitoring plan must be prepared and implemented. That plan defines steps to be taken to determine if the facility is the contaminant source and, if so, to determine the magnitude and extent of the contamination. RCRA facilities under the groundwater quality assessment phase may require an expanded groundwater-monitoring network and be monitored quarterly. Ecology may require corrective action through an administrative order if the results of the assessment indicate significant hazards to human health and the environment.

To determine whether a statistically significant change has occurred, the sample results from upgradient wells during the first year of monitoring are averaged, and summary statistics (mean, standard deviation, and coefficient of variation) are developed for each RCRA facility. Once the background summary statistics have been developed, the averaged-replicate t-test (OSWER-9950.1) is used to calculate the test statistic for each contaminant indicator parameter. The test statistic is reformulated in such a way that a critical mean can be obtained for each indicator parameter. These critical means have been adjusted to control the overall facility false-positive rate at $1 \%$, which is consistent with the performance standard required for RCRA facilities operated under interim status (40 CFR 265.93[b]). 


\section{RCRA Final Status}

Site-specific groundwater-monitoring requirements (e.g., well networks, analyte lists) for final-status RCRA facilities are negotiated and included in the Hanford Facility RCRA Permit (Ecology 1994). These requirements are incorporated into the permit as site-specific groundwater-monitoring plans, which are prepared according to the permit-modification schedule. Facilities currently conducting finalstatus groundwater monitoring and the date that current interim-status facilities are scheduled to become final status were listed in Table III.B-1.

Three phases of groundwater monitoring are specified under final-status regulations: detection monitoring, compliance monitoring, and corrective action.

In a detection-monitoring program, groundwater-sampling results from downgradient wells for parameters listed in the unit-specific groundwater-monitoring plan are compared with those from background wells to determine whether there has been a statistically significant change from background concentrations. Statistical methods appropriate for a final-status detection-monitoring program include analysis of variance, tolerance intervals, prediction intervals, control charts, test of proportions, or other statistical methods approved by Ecology. The distribution(s) of monitoring parameters; the nature of the data; the proportions of nondetections; and seasonal, temporal, and spatial variations are important factors to consider when selecting appropriate statistical methods. The statistical evaluation procedures chosen are based on PB89-151047, EPA/530-R-93-003, Gibbons (1992), and ASTM (1996). Specifics are addressed in the unit-specific permit applications.

A compliance groundwater-monitoring program is established if detection monitoring reveals a statistically significant change in an indicator parameter. The objective of compliance-level monitoring is to determine if the monitored facility is in compliance with groundwater-protection standards. This is accomplished by comparing the concentrations of constituents of concern to groundwater-protection standards such as the risk-based maximum concentration limit; an alternate concentration limit; natural background; or applicable, relevant, and appropriate requirements.

Maximum concentration limits are identified for each of the groundwater-monitoring parameters listed in Table 1 of WAC 173-303-645. Alternate concentration limits may be proposed after considering the observed concentrations of chemical constituents in the groundwater that might originate from the regulated unit in question. The area background, natural background, and other standards and requirements that are applicable, relevant, and appropriate are evaluated when proposing an alternate concentration limit.

If, during compliance-level monitoring, the referenced concentration limit(s) for a given groundwater parameter(s) is significantly exceeded, a corrective action program is developed and implemented to protect human health and the environment. Details for the corrective action program are specified in the unit-specific permit applications or closure plans. Additionally, a groundwater-monitoring plan used to assess the effectiveness of the corrective action measures is submitted. That monitoring plan is similar in scope to the compliance-level groundwater-monitoring program and includes all relevant information pertaining to the location and description of monitoring wells, monitoring network, well construction and development, sampling and analysis plans, statistical methods, and quality procedures.

Under final-status regulations, all wells at each TSD unit must be sampled at least semiannually. Two sampling procedures are allowed: a sequence of at least four samples is taken over a time interval that ensures, to the greatest extent technically feasible (default sampling procedure), that an independent 
sample is obtained or an alternate sampling procedure approved by the regulator(s) that is protective of human health and the environment (40 CFR 264.97, WAC 173-303-645). Specific sampling frequencies and statistical evaluation methods are provided in the unit-specific groundwater-monitoring plan.

\section{CERCLA Past-Practice/RCRA Corrective Action Groundwater Monitoring}

Groundwater monitoring is conducted to support the CERCLA past-practice and RCRA corrective action characterization and remediation activities at inactive sites. For the purpose of conducting these activities, the waste sites (called past-practice sites) and associated contaminated groundwater have been grouped into operable units (OUs). There are 63 source (waste site), 10 groundwater, and 1 combined source/groundwater OUs. Groundwater OUs are linked to numerous source OUs, which may have contributed to regional plumes of contamination but are treated separately from the source units for remediation. The locations of the groundwater OUs are shown on Figure III.B-4.

The OUs are designated as either RCRA past-practice units or CERCLA past-practice units. This designation ensures that only one past-practice program is applied to each OU. The same groundwatermonitoring activities are conducted at the OUs regardless of the applicable regulatory past-practice program.

Characterization-phase monitoring is performed to support decisions leading to a ROD or permit modification for the OU. Surveillance-phase monitoring is conducted to meet the objectives of the final ROD or permit modification issued for the OU. One OU (1100-EM-1) has received a final ROD (ROD 1993), which requires surveillance-phase monitoring. Maintenance-phase monitoring is conducted at OUs where characterization monitoring has been completed but the ROD or permit modification has not yet been issued. Maintenance-phase monitoring is also conducted at sites where an interim ROD or expedited response action is in effect. As of September 1997, characterization monitoring is complete but RODs or permit modifications have not been issued for OUs 100-BC-5, 100-FR-3, 200-BP-5, and 200-PO-1. Requirements for maintenance-phase monitoring at these sites is specified in letters to Ecology that are part of the administrative record. OUs where an interim ROD has been issued include 200-UP-1 (ROD 1997), 200-ZP-1 (ROD 1995), 300-FF-5 (ROD 1996a), 100-HR-3 and 100-KR-4 (ROD 1996b). An expedited response action is being conducted at OU 100-NR-2 (ERA 1994). Characterization-, maintenance-, and surveillance-phase monitoring conducted at these sites also meet the objectives of DOE Order 5400.1.

Additional groundwater monitoring is conducted outside of but consistent with this Environmental Monitoring Plan. This type of monitoring is focused strictly on evaluating the performance of groundwater-remediation activities at an expedited response action site (e.g., 100-NR-2) and at interim ROD sites (e.g., 100-HR-3, 100-KR-4, 200-UP-1, and 200-ZP-1).

A listing of the groundwater. OUs, the regulatory classification, the current status of each relative to ROD/RCRA permit modification, and the general category of environmental monitoring is given in Table III.B-2. The sampling schedules and constituent lists for all groundwater OUs will be published in a separate annual sampling schedule (e.g., PNNL-11464) and the results will be reported in the annual report (e.g., PNNL-11470). 


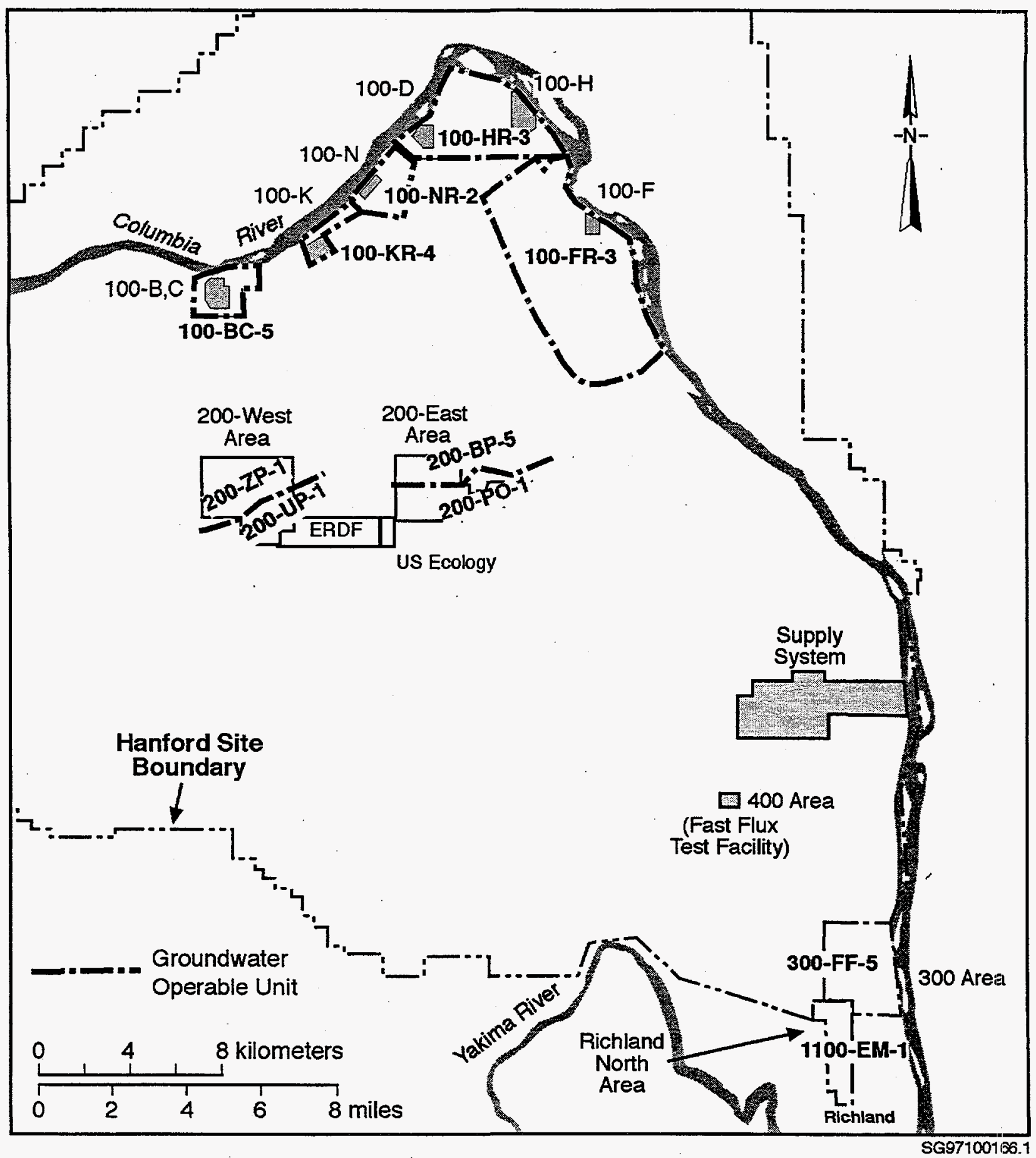

Figure III.B-4. Groundwater Operable Units on the Hanford Site 
Table III.B-2. Groundwater Operable Unit Summary - Environmental Monitoring

\begin{tabular}{|c|c|c|c|}
\hline Operable Unit Designation & $\begin{array}{l}\text { Regulatory Program } \\
\text { Classification } \\
\end{array}$ & $\begin{array}{l}\text { Status Relative to } \\
\text { ROD/RCRA Permit }\end{array}$ & $\begin{array}{c}\text { Monitoring } \\
\text { Category }\end{array}$ \\
\hline $\begin{array}{l}1100-E M-1 \text { (Groundwater and } \\
\text { Source Operable Unit) }\end{array}$ & $\mathrm{CPP}$ & Post-ROD & Surveillance \\
\hline $300-F F-5$ & $\mathrm{CPP}$ & Interim ROD & Maintenance \\
\hline $100-B C-5$ & $\mathrm{CPP}$ & Pre-ROD & Maintenance \\
\hline 100-FR-3 & CPP & Pre-ROD & Maintenance \\
\hline $100-H R-3$ & CPP & Interim ROD & Maintenance \\
\hline $100-K R-4$ & CPP & Interim ROD & Maintenance \\
\hline $100-N R-2$ & RPP & Pre-Permit \& ERA & Maintenance \\
\hline $200-\mathrm{BP}-5$ & $\mathrm{CPP}$ & Pre-ROD & Maintenance \\
\hline 200-PO-1 & RPP & Pre-Permit & Maintenance \\
\hline 200-UP-1 & CPP & Interim ROD & Maintenance \\
\hline $200-Z P-1$ & CPP & Interim ROD & Maintenance \\
\hline
\end{tabular}

CERCLA = Comprehensive Environmental Response, Compensation, and Liability Act of 1980.

CPP = CERCLA past-practice.

ERA = expedited response action.

RCRA = Resource Conservation and Recovery Act of 1976.

ROD $=$ record of decision.

RPP = RCRA past-practice.

\section{Sitewide Environmental Surveillance of Groundwater}

Additional sitewide monitoring of groundwater is required to meet the environmental surveillance program objectives stated in DOE Order 5400.1 and described in DOE/EH-0173T. The primary objectives addressed by sitewide groundwater monitoring are the following:

- evaluation of existing and potential offsite impacts of groundwater contaminants from the Hanford Site

- providing an integrated assessment of groundwater quality

- characterizing and defining hydrogeologic, physical, and chemical trends in the sitewide groundwater system

- establishing baselines of groundwater quality

- assessing existing and emerging groundwater quality problems.

The movement of existing widespread contaminant plumes is tracked, and flow-system characterization and modeling are conducted to predict future plume movement. These activities allow actual and 
potential impacts to offsite water users to be evaluated. This section identifies the rationale and design criteria for sitewide monitoring of radiological and chemical contaminants in groundwater.

Data from operational and compliance monitoring (e.g., RCRA, CERCLA) of groundwater near specific facilities are integrated with information from the sitewide monitoring network. Data from wells that supply water to the Fast Flux Test Facility water system are also used in the sitewide interpretation. The sitewide monitoring network is designed to supplement these data to meet the objectives listed above. Additional wells selected for sampling each year generally fall into the following categories:

- contaminant source areas - Source areas include regions with active waste-disposal facilities or with facilities that have generated or received waste in the past. These data are generally provided by facility-specific monitoring networks. However, additional wells may be identified to characterize contaminant sources and to supplement operational monitoring networks.

- known contaminant plumes - Wells located within known contaminant plumes are monitored to characterize and define trends in the concentrations of radiological or chemical constituents. These wells are also monitored to meet the objective to quantify existing groundwater quality problems and to provide a baseline of environmental conditions against which future changes can be assessed.

- near water supplies - Water-supply wells on and near the site potentially provide a route for human exposure to contaminants in groundwater. Three water supplies exist onsite: Fast Flux Test Facility, Yakima Barricade guardhouse, and Hanford Patrol academy. Water-supply wells for the City of Richland are adjacent to the southern boundary of the Hanford Site. Wells near these water supplies and, in some cases, the water-supply wells themselves, are monitored to identify potential water quality impacts.

- Hanford Site perimeter - Wells along the Hanford Site perimeter are monitored to assess the quality of groundwater as it leaves the site. Wells along the northern, eastern, and southern boundaries of the site have been identified. Data from these wells help address objectives, including evaluation of existing and potential offsite impacts of groundwater contaminants, establishment of baselines of groundwater quality, and assessment of existing and emerging groundwater quality problems.

- offsite - Groundwater is utilized as a source for domestic and agricultural water outside the Hanford Site. Offsite wells may be monitored periodically to ensure that contaminants from Hanford Site sources are not present and to maintain a baseline of information on offsite water quality.

- background areas - Wells in areas upgradient from Hanford Site operations are sampled to provide information on background groundwater quality. These data are needed to assess the impact of site operations on groundwater and also to identify contaminants contributed by offsite upgradient sources.

Wells planned for sampling and constituents to be analyzed during each fiscal year will be published in a separate sampling schedule (e.g., PNNL-11464). Results of sitewide groundwater monitoring are discussed in the annual groundwater report (e.g., PNNL-11470). Figure III.B-1 showed the distribution of wells sampled during fiscal year 1996 for the unconfined aquifer system. Wells completed in the upper basalt-confined aquifer system are sampled to monitor groundwater conditions and the movement of contaminants found in this aquifer near the 200 Areas. Basalt-confined aquifer wells near the perimeter of the site are also monitored periodically. Wells completed in the basalt-confined aquifer and 
sampled during fiscal year 1996 were identified in Figure III.B-2. The monitoring well network may change from year to year based on groundwater-flow conditions, movement of contaminant plumes, and project objectives.

Analytes for the sitewide monitoring network wells are selected based on the constituents present in nearby plumes and the inventories of potential groundwater contaminants at upgradient sources. Sampling frequencies vary from monthly to less than annually based on observed plume movements and expected changes in constituent concentrations. The analytes selected for each well will be listed in the sampling schedule and results will be presented in the annual groundwater report.

\section{Exceptions}

No exceptions have been taken to should* statements in DOE/EH-0173T.

\section{References}

ASTM (American Society for Testing and Materials). 1996. Provisional Standard Guide for Developing Appropriate Statistical Approaches for Ground-Water Detection Monitoring Programs. PS 64-96, West Conshohocken, Pennsylvania.

10 CFR 830.120, Code of Federal Regulations, Title 10, Part 830, Chapter 120. Nuclear Safety Management, Quality Assurance Requirements.

40 CFR 264, Code of Federal Regulations, Title 40, Part 264. Standards for Owners and Operators of Hazardous Waste Treatment, Storage, and Disposal Facilities.

40 CFR 265, Code of Federal Regulations, Title 40, Part 265. Interim Status Standards for Owners and Operators of Hazardous Waste Treatment, Storage, and Disposal Facilities.

40 CFR 300, Code of Federal Regulations, Title 40, Part 300. National Oil and Hazardous Substances Pollution Contingency Plan.

40 CFR 300, Code of Federal Regulations, Title 40, Part 300, Appendix B. National Priorities List.

Comprehensive Environmental Response, Compensation, and Liability Act of 1980, as amended, Public Law 96-510, 94 Stat. 2767, 42 USC 9601 et seq.

DOE/EH-0173T. 1991. Environmental Regulatory Guide for Radiological Effluent Monitoring and Environmental Surveillance. Assistant Secretary for Environment, Safety and Health, U.S. Department of Energy, Washington, D.C.

DOE Order 5400.1. "General Environmental Protection Program."

DOE Order 5400.5. "Radiation Protection of the Public and the Environment."

DOE Order 5820.2A. "Radioactive Waste Management." 
DOE/RL-89-12, Rev. 2. 1995. Hanford Site Ground-Water Protection Management Plan. D. B. Barnett, J. S. Schmid, S. S. Lowe, W. L. Allen, N. A. Ballantyne, C. H. Dohrer, M. J. Hartman, F. N. Hodges, D. G. Horton, V. G. Johnson, K. L. Lueck, D. J. Ortiz, A. J. Knepp, B. H. Ford, S. P. Hope, D. K. Tyler, R. D. Hildebrand, D. E. Olson, R. E. Peterson, G. L. Kasza, D. A. Myers, S. P. Luttrell, P. D. Thorne, and K. R. Moser, U.S. Department of Energy, Richland Operations Office, Richland, Washington.

Ecology (State of Washington Department of Ecology). 1994. Hanford Facility RCRA Permit. Permit WA7890008967, effective September 28, 1994, Olympia, Washington.

Ecology (State of Washington Department of Ecology) and EPA (U.S. Environmental Protection Agency). 1986. Consent Agreement and Compliance Order. Ecology No. DE 86-133, Olympia and Seattle, Washington.

Ecology (State of Washington Department of Ecology), EPA (U.S. Environmental Protection Agency), and DOE (U.S. Department of Energy). 1989. Hanford Federal Facility Agreement and Consent Order Between the U.S. Environmental Protection Agency, the U.S. Department of Energy, and the State of Washington Department of Ecology, May 15, 1989, as amended. Olympia, Seattle, and Richland, Washington.

EPA/530-R-93-003. 1992. Statistical Analysis of Ground-Water Monitoring Data at RCRA Facilities Addendum to Interim Final Guidance (Draft). U.S. Environmental Protection Agency, Washington, D.C.

EPA-600/4-79-020. 1983. Methods for Chemical Analysis of Water and Wastes. U.S. Environmental Protection Agency, Cincinnati, Ohio.

ERA (Expedited Response Action). 1994. Action Memorandum: N Springs Expedited Response Action Cleanup Plan, U.S. Department of Energy Hanford Site, Richland WA. State of Washington Department of Ecology, Olympia, Washington to U.S. Department of Energy, Richland, Washington.

Gibbons, R. D. 1994. Statistical Methods for Groundwater Monitoring. John Wiley and Sons, Inc., New York.

OSWER-9950.1. 1986. Resource Conservation and Recovery Act (RCRA) Groundwater Monitoring Technical Enforcement Guidance Document. U.S. Environmental Protection Agency, Washington, D.C.

PB89-151047. 1989. Statistical Analysis of Ground-Water Monitoring Data at RCRA Facilities Interim Final Guidance. U.S. Environmental Protection Agency, Washington, D.C.

PNNL. 1997. "Subject Areas (Standards, Procedures and Guidelines), A-Manuals." In StandardsBased Management System [Online]. Available URL: http://wwwi.pnl.gov:2080/.

PNNL-1 1464. 1997. Environmental Surveillance Master Sampling Schedule. L. E. Bisping, Pacific Northwest National Laboratory, Richland, Washington.

PNNL-1 1470. 1997. Hanford Site Groundwater Monitoring for Fiscal Year 1996. M. J. Hartman and P. E. Dresel (eds.), Pacific Northwest National Laboratory, Richland, Washington.

Resource Conservation and Recovery Act of 1976, as amended, Public Law 94-580, 90 Stat. 2795, 42 USC 6901 et seq. 
ROD (Record of Decision). 1993. Record of Decision, USDOE Hanford 1100 Area, Hanford Site, Richland, Washington. Washington State Department of Ecology, U.S. Environmental Protection Agency, and U.S. Department of Energy, Richland Operations Office, Richland, Washington.

ROD (Record of Decision). 1995. Declaration of the Record of Decision, USDOE Hanford 200 Area, Hanford Site, Benton County, Washington (200-ZP-1). Washington State Department of Ecology, U.S. Environmental Protection Agency, and U.S. Department of Energy, Richland Operations Office, Richland, Washington.

ROD (Record of Decision). 1996a. Declaration of the Record of Decision for the 300-FF-1 and 300-FF-5 Operable Units. Washington State Department of Ecology, U.S. Environmental Protection Agency, and U.S. Department of Energy, Richland Operations Office, Richland, Washington.

ROD (Record of Decision). 1996b. Declaration of the Record of Decision, USDOE Hanford 100 Area, 100-HR-3 and 100-KR-4 Operable Units, Hanford Site, Benton County, Washington, April 1996. Washington State Department of Ecology, U.S. Environmental Protection Agency, and U.S. Department of Energy, Richland Operations Office, Richland, Washington.

ROD (Record of Decision). 1997. Declaration of the Record of Decision, U.S. DOE Hanford 200 Area, Hanford Site, Benton County, Washington (200-UP-1). Washington State Department of Ecology, U.S. Environmental Protection Agency, and U.S. Department of Energy, Richland Operations Office, Richland, Washington.

Superfund Amendments and Reauthorization Act of 1986, as amended, Public Law 99-499, 100 Stat. 1613, 42 USC 11001 et seq.

SW-846. 1986. Test Methods for Evaluating Solid Wastes: Physical/Chemical Methods, 3rd ed. Office of Solid Waste and Emergency Response, U.S. Environmental Protection Agency, Washington, D.C.

WAC 173-160, Washington Administrative Code. Minimum Standards for Construction and Maintenance of Wells. Olympia, Washington.

WAC 173-216, Washington Administrative Code. State Waste Discharge Program. Olympia, Washington.

WAC 173-303, Washington Administrative Code. Dangerous Waste Regulations. Olympia, Washington.

WAC 173-303-400, Washington Administrative Code. Interim Status Facility Standards. Olympia, Washington.

WAC 173-303-645, Washington Administrative Code. Releases from Regulated Units. Olympia, Washington.

WAC 173-304, Washington Administrative Code. Minimum Functional Standards for Solid Waste Handling. Olympia, Washington.

WAC 173-304-490, Washington Administrative Code. Ground Water Monitoring Requirements. Olympia, Washington. 
WHC-SD-EN-EV-008. 1991. A Methodology for Assessing Impacts to Groundwater from Disposal of Liquid Effluent to the Soil at the Hanford Site. Westinghouse Hanford Company, Richland, Washington. 


\title{
Hanford Site Environmental Monitoring Plan
}

\author{
Section III.C. Meteorological Monitoring
}

\begin{tabular}{|l|l|}
\hline Prepared by: & $\begin{array}{l}\text { Doncurrence: } \\
\text { D. J. Hoitink, Pacific Northwest National } \\
\text { Laboratory }\end{array}$ \\
\hline
\end{tabular}




\section{Introduction}

Meteorological monitoring is another aspect of the U.S. Department of Energy's (DOE's) requirements for environmental monitoring and is designed to meet the environmental and meteorological monitoring program objectives stated in DOE Order 5400.1 and described in DOE/EH-0173T. This section identifies the data required to support environmental monitoring activities and to represent other meteorological conditions important to these activities. Also, as an essential element of all environmental monitoring plans, a meteorological information/monitoring program has been developed and is reported on annually (e.g., PNNL-11471).

$\mathrm{DOE} / \mathrm{EH}-0173 \mathrm{~T}$ details the specific requirements of a meteorological monitoring program and addresses the following considerations:

- meteorological program basis

- meteorological data for dose assessment calculations

- meteorological measurements

- inspection, maintenance, and calibration

- data summarization and archiving

- quality assurance.

This section discusses the composition of the Hanford Site meteorological monitoring program as it relates to DOE Order 5400.1 and DOE/EH-0173T.

\section{Meteorological and Climatological Services Project}

The Pacific Northwest National Laboratory (PNNL) Meteorological and Climatological Services Project provides the DOE-Richland Operations Office (RL) and Hanford Site contractors with meteorological and climatological support for emergency response, weather forecasting, climatological data, and related special requests through the operation of the Hanford Meteorology Station (HMS). The project responds to Hanford Site needs through a program that includes the following:

- extensive data acquisition through a sitewide meteorological monitoring network

- site-specific forecasts, using weather satellite imagery and National Weather Service products (through the Automation of Field Operations and Services system)

- standard hourly surface weather observations and 6-h synoptic observations

- climatological data through monthly and annual summaries (e.g., PNNL-11471), meteorological input to annual environmental reports (e.g., PNNL-11472), and responses to ad hoc requests. 


\section{Meteorological Monitoring Network}

The Hanford Site covers a large area with significant variations in topography and with elevations ranging from approximately 100 to nearly $1,100 \mathrm{~m}$ above sea level. To characterize the meteorological conditions on and around the Hanford Site, 30 monitoring stations have been installed onsite and nearby offsite (Table III.C-1 and Figure III.C-1). Station locations were selected to reflect the influence of the varied topography, especially on wind speed and direction, and to provide appropriate data for atmospheric transport and diffusion modeling and for site characterization. The station-selection process was based on an understanding of the effects of synoptic- and meso-scale meteorological events on wind flow over the Hanford Site and also from model studies of atmospheric transport that were run specifically to indicate areas where additional wind data were required. The meteorological monitoring network was designed to perform the following functions:

- to represent implicitly the effect of the varying topography of the Hanford Site on atmospheric circulations by strategic siting of the individual stations

- to monitor and collect real-time meteorological data at locations where operations are conducted that could have a possible negative impact in the event of an emergency

- to provide meteorological data for daily operational forecasting for Hanford Site activities

- to provide real-time meteorological data for atmospheric transport and diffusion modeling

- to provide climatological data for environmental assessments, environmental impact statements, facilities planning, etc.

A $125-\mathrm{m}$ tower, located at the HMS, is instrumented at multiple levels for wind speed and direction and temperature. This tower has been used for collecting data since the mid-1940s. Three $60-\mathrm{m}$ monitoring stations, instrumented at multiple levels, are located in onsite areas where significant operations are conducted. These stations provide additional necessary information as input to atmospheric transport and diffusion models. Twenty-six 10-m towers are instrumented for wind speed and direction (at $10 \mathrm{~m}$ ) and temperature (at $2 \mathrm{~m}$ ). Most stations also record precipitation. Detailed descriptions of each meteorological monitoring site, including narrative and photographic depictions of the topography proximate to each, can be found in PNL-6684.

\section{Meteorological Instrumentation}

The meteorological instrumentation provides data, including wind speed and direction, temperature, vertical temperature difference, dew-point temperature, and precipitation. Other data are collected via the surface observation program, including sky condition, cloud type and amount, ceiling height, mixing depth, atmospheric pressure, weather and obstructions to visibility, relative humidity, and solar radiation (PNL-6509).

Wind. Wind speed and direction are measured at the $10-\mathrm{m}$ level at all of the remote meteorological monitoring stations, at the $25-$ and $60-\mathrm{m}$ levels on the three $60-\mathrm{m}$.towers onsite (see Table III.C-1), and at the 2.1-, 15.2-, 30.5-, 61.0-, 91.4-, and 121.9-m levels on the 125-m tower at the HMS.

Wind speed at most monitoring stations (except Stations 19, 20, 22, and 25) (see Figure III.C-1) is measured using sensors (3-cup heavy-duty aluminum anemometer) with a low starting threshold over a 
Table III.C-1. Hanford Site Meteorological Monitoring Towers

\begin{tabular}{|c|c|c|c|}
\hline Site Number & Site Name & Height, $m$ & Instrumentation \\
\hline 1 & Prosser Barricade & 10 & WS, WD, T, P \\
\hline 2 & Emergency Operations Center & 10 & WS, WD, T, P \\
\hline 3 & Army Loop Road & 10 & $\mathrm{WD}, \mathrm{T}, \mathrm{P}$ \\
\hline 4 & Rattlesnake Springs & 10 & WS, WD, T, P \\
\hline 5 & Edna & 10 & WS, WD, T \\
\hline 6 & 200-East Area & 10 & $\mathrm{WS}, \mathrm{WD}, \mathrm{T}, \mathrm{P}, \mathrm{AP}$ \\
\hline 7 & 200-West Area & 10 & $\mathrm{WS}, \mathrm{WD}, \mathrm{T}, \mathrm{P}$ \\
\hline 8 & Beverly & 10 & WS, WD, T, P \\
\hline 9 & Fast Flux Test Facility & 60 & WS, WD, T, TD, DP, P, AP \\
\hline 10 & Yakima Barricade & 10 & WS, WD, T, P, AP \\
\hline 11 & 300 Area & 60 & $\mathrm{WS}, \mathrm{WD}, \mathrm{T}, \mathrm{TD}, \mathrm{DP}, \mathrm{P}, \mathrm{AP}$ \\
\hline 12 & Wye Barricade & 10 & WS, WD, T, P \\
\hline 13 & $100-\mathrm{N}$ Area & 60 & WS, WD, T, TD, DP, P, AP \\
\hline 14 & WNP-2 & 10 & WS, WD, T, P \\
\hline 15 & Franklin County & 10 & WS, WD, T \\
\hline 16 & Gable Mountain & 10 & WS, WD, T \\
\hline 17 & Ringold & 10 & WS, WD, T, P \\
\hline 18 & Richland Airport & 10 & WS, WD, T, AP \\
\hline 19 & $\begin{array}{l}\text { 200-West (Plutonium Finishing } \\
\text { Plant) }\end{array}$ & 10 & $\mathrm{WS}, \mathrm{WD}, \mathrm{T}, \mathrm{AP}$ \\
\hline 20 & Rattlesnake Mountain & 10 & WS, WD, T, P \\
\hline 21 & Hanford Meteorology Station & 125 & $\mathrm{WS}, \mathrm{WD}, \mathrm{T}, \mathrm{P}, \mathrm{AP}$ \\
\hline 22 & Pasco & 10 & WS, WD, T, P \\
\hline 23 & Gable West & 10 & WS, WD, T \\
\hline 24 & 100-F Area & 10 & WS, WD, T, P \\
\hline 25 & Vernita Bridge & 10 & WS, WD, T \\
\hline 26 & Benton City & 10 & $\mathrm{WS}, \mathrm{WD}, \mathrm{T}, \mathrm{P}$ \\
\hline 27 & Vista & 10 & $\mathrm{WS}, \mathrm{WD}, \mathrm{T}, \mathrm{P}$ \\
\hline 28 & Roosevelt & 10 & WS, WD, T, AP, P \\
\hline 29 & K-Basin & 10 & WS, WD, T, AP, P \\
\hline 30 & HAMMER & 10 & WS, WD, T \\
\hline \multicolumn{4}{|c|}{$\begin{array}{l}\mathrm{AP}=\text { atmospheric pressure } \\
\mathrm{DP}=\text { dew-point temperature. } \\
\mathrm{P}=\text { precipitation. } \\
\mathrm{T}=\text { temperature. } \\
\mathrm{TD}=\text { temperature difference. } \\
\mathrm{WD}=\text { wind direction. } \\
\mathrm{WS}=\text { wind speed. }\end{array}$} \\
\hline
\end{tabular}




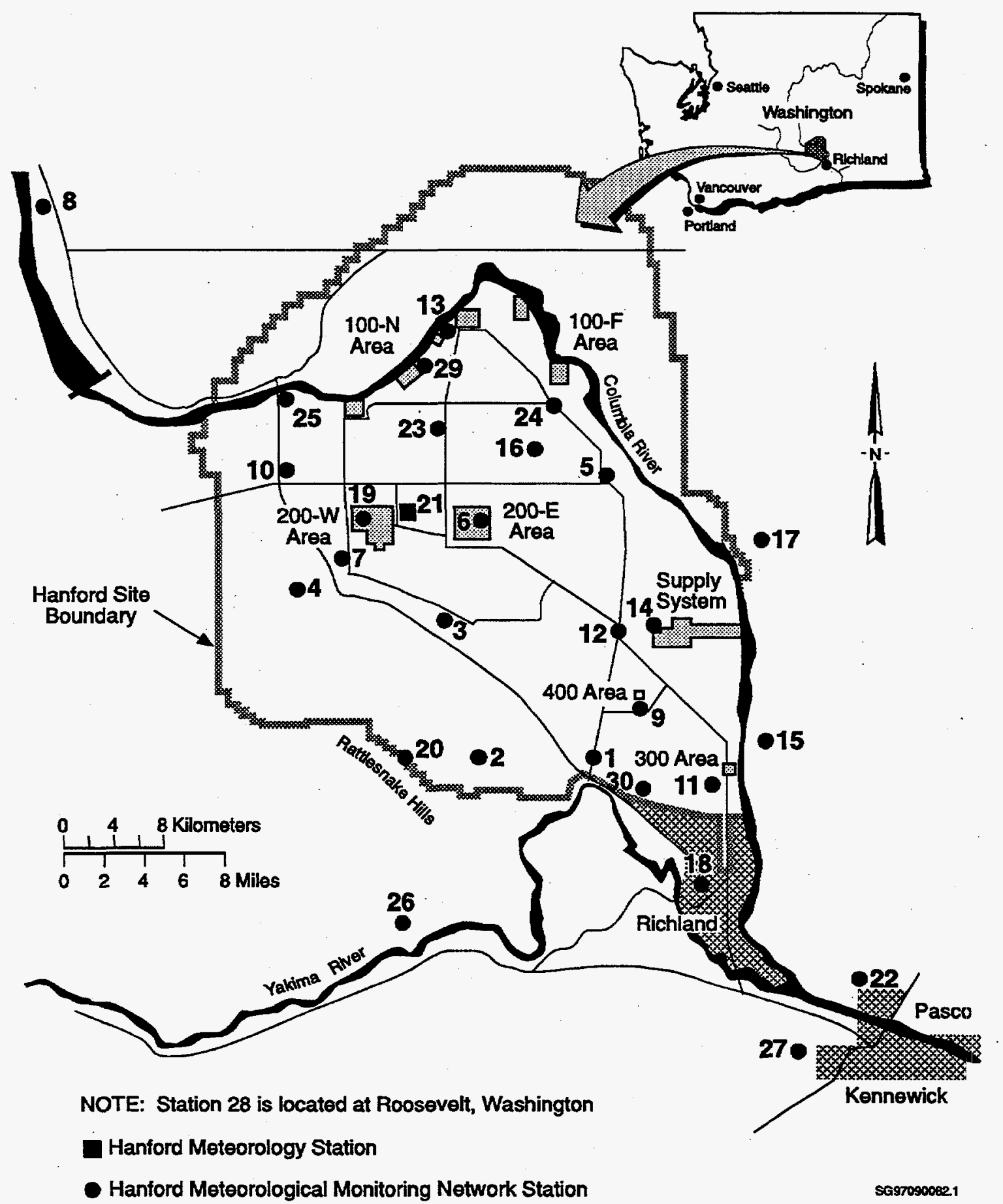

Figure III.C-1. Meteorological Monitoring Stations on the Hanford Site and in Surrounding Areas 
wide range of wind speeds. At Station 20, located on the top of Rattlesnake Mountain, where light winds are unusual and sustained wind speeds in excess of $45 \mathrm{~m} / \mathrm{s}$ are common, a sturdier anemometer (with a higher starting threshold but a greater range) is used. At Stations 19, 22, and 25, which are solar powered, a wind monitor (with a propeller, rather than a cup anemometer) is used because it is less susceptible to freezing (because of moisture and fog). The wind-speed sensor specifications, by station number, are indicated below:

- Stations 1 to $18,23,24,26$ to 30

Threshold

Operating range

Accuracy

- Station 19

Threshold

Operating range

$1.0 \mathrm{~m} / \mathrm{s}$

0 to $60 \mathrm{~m} / \mathrm{s}$ (gust survivability to $100 \mathrm{~m} / \mathrm{s}$ )

- Station 20

Threshold

Operating range

1 to $2 \mathrm{~m} / \mathrm{s}$

0 to $90 \mathrm{~m} / \mathrm{s}$ (gust survivability to $90+\mathrm{m} / \mathrm{s}$ )

- Station 22

Threshold

$1.0 \mathrm{~m} / \mathrm{s}$

Operating range

- Station 25

Threshold

$0.4 \mathrm{~m} / \mathrm{s}$

Operating range

0 to $40 \mathrm{~m} / \mathrm{s}$ (gust survivability to $45 \mathrm{~m} / \mathrm{s}$ ).

Wind-direction sensors at most of the monitoring stations, except Stations 19, 20, 22, and 25 where wind monitors are used, are counterbalanced, lightweight vanes attached to a shaft coupled to a precision low-torque potentiometer. These sensors have low starting thresholds and fast dynamic response. The wind-direction sensor specifications, by station number, are indicated below:

- Stations 1 to $18,23,24,26$ to 30

Threshold

$0.22 \mathrm{~m} / \mathrm{s}$

Operating range

0 to 360 degrees

Accuracy

\pm 2 degrees

Damping ratio

Distance constant

0.4 at 10 degrees initial angle of attack

$1.1 \mathrm{~m}$ 
- Station 19

Threshold

Operating range

Accuracy

- Station 20

Threshold

Operating range

Accuracy

- Station 22

Threshold

Operating range

Accuracy

- Station 25

Threshold

Operating range

Accuracy
$1.0 \mathrm{~m} / \mathrm{s}$

0 to 360 degrees

\pm 5 degrees

The wind-speed and wind-direction sensors at all monitoring locations, except Stations 19, 20, 22 , and 25 , are heated to minimize the accumulation of rime and/or freezing precipitation during the winter.

Temperature. Air temperature is measured at $1.7 \mathrm{~m}$ at all of the monitoring stations, with additional measurements at the 10 - and $60-\mathrm{m}$ levels (for measurement of $\Delta T$ for atmospheric stability designation) at the three $60-\mathrm{m}$ monitoring stations (see Table III.C-1). Temperature is measured at the 0.9-, 9.1-, 15.2-, 30.5-, 61.0-, 76.2-, 91.4-, and 121.9-m levels on the 125-m tower.

The temperature sensor (on all but the $125-\mathrm{m}$ tower) is an epoxy-coated thermistor composite that exhibits relatively large resistance changes in response to small temperature changes. Fast-response sensors (with a time constant of $0.6 \mathrm{~s}$ ) are used. All of the $10-\mathrm{m}$ monitoring stations have naturally aspirated radiation shields, and the three $60-\mathrm{m}$ stations have mechanically aspirated shields. The thermistor temperature sensor specifications are given below:

$\begin{array}{ll}\text { Probe accuracy } & \pm 0.15^{\circ} \mathrm{C} \\ \text { Range } & -30.0 \text { to } 50.0^{\circ} \mathrm{C} \\ \text { Time constant } & 0.6 \mathrm{~s} .\end{array}$

On the $125-\mathrm{m}$ tower, temperatures are measured using a platinum resistance temperature device contained in a 15-cm-long stainless-steel housing mounted in a mechanically aspirated radiation shield. The platinum resistance temperature sensor specifications are given below:

$\begin{array}{ll}\text { Probe accuracy } & \pm 0.1^{\circ} \mathrm{C} \\ \text { Range } & -50.0 \text { to } 100.0^{\circ} \mathrm{C} \\ \text { Time constant } & 15 \mathrm{~s} .\end{array}$


Temperature Differencing. Temperature differencing is one of several methods used to determine atmospheric stability, which is one of the parameters used in transport and diffusion calculations. Atmospheric stability is a measurement of the buoyancy of a parcel of air. The buoyancy of a parcel of air depends on its density relative to the density of the environment at the same level. If a parcel is heavier than its environment, it will tend to sink (stable); if a parcel is lighter than its environment, it will tend to rise (unstable); and if the weight is the same, it will remain at the same level as its environment (neutral). Stability classes can be determined by measuring the difference between air temperatures at two levels.

The $\Delta \mathrm{T}$ calculation at the $125-\mathrm{m}$ tower is made using the difference between actual temperatures measured at the 61.0- and 9.1-m levels of the tower. At the three $60-\mathrm{m}$ monitoring stations, which measure temperature difference rather than actual temperature between 10 and $60 \mathrm{~m}$, a $\Delta \mathrm{T}$ translator contains the electronics for converting the variable resistance from the temperature thermistor elements to low-impedance signals, then takes the difference between the two signals and converts this difference into a $\Delta \mathrm{T}$. The temperature sensors used are discussed above.

Dew-Point Temperature. Dew-point temperature is measured at the $1.7-\mathrm{m}$ level at the three $60-\mathrm{m}$ towers. The dew-point sensor is housed in a mechanically aspirated temperature/dew-point shield and consists of bifilar gold electrodes wound on a lithium chloride-impregnated glass fiber wick that encloses a thermistor temperature sensor. The dew-point sensor specifications are given below:

Operating range

Relative humidity

operating limits
-40 to $+50^{\circ} \mathrm{C}$

From $100 \%$ to the relative humidity at which the lithium chloride salt temperature is $2^{\circ} \mathrm{C}$ above the ambient temperature $(11 \%$ to $18 \%$ relative humidity).

At the HMS, a hygrothermometer system is used to measure the dew-point temperature. The monitor is located $1.5 \mathrm{~m}$ above the ground and uses a chilled-mirror system to monitor the dew point. The specifications for the hygrothermometer are the following:

Operating temperature

Relative humidity

Ambient temperature

Dew-point accuracy
-50 to $70^{\circ} \mathrm{C}$

$5 \%$ to $100 \%$

$\pm 0.6^{\circ} \mathrm{C}$ from -50 to $50^{\circ} \mathrm{C}$ accuracy

$\pm 0.6^{\circ} \mathrm{C}$ when $>0^{\circ} \mathrm{C}$.

Precipitation. Precipitation measurements, using recording rain gauges, are made at 22 of the 30 monitoring stations. Each rain gauge has a $20-\mathrm{cm}$-diameter opening to collect precipitation. Two compartments alternately fill with precipitation and tip (emptying the compartment), causing momentary closure of a mercury switch. The funnels are electrically heated for measuring the water equivalent of frozen precipitation. The heater is thermostatically controlled to be activated when the ambient temperature drops to $4^{\circ} \mathrm{C}$. These gauges are sensitive to $0.25 \mathrm{~mm}$ and are accurate to $0.5 \%$ for a rainfall rate of $12.70 \mathrm{~mm} / \mathrm{h}$. The average precipitation event at the HMS is only $2.3 \mathrm{~mm}$.

Atmospheric Pressure. Atmospheric pressure is measured at the $2-\mathrm{m}$ level at the 10 sites indicated in Table III.C-1. The sensors are located within the signal interface unit enclosures. The pressure sensor specifications are given below:
Scaling range
800 to $1,100 \mathrm{mb}$
Nonlinearity $\pm 0.05 \%$ of full scale
Full-scale accuracy
$\pm 0.1 \%$ of full scale or $\pm 0.3 \mathrm{mb}$. 


\section{Instrument Calibration and Maintenance}

All measurement and test equipment is calibrated on an annual basis, and the calibrations are spread throughout the year. The maintenance services calibration recall system is used to notify the project manager when instrument calibration is due. However, because data are reviewed hourly by the forecaster on duty, any apparent problems with data from a particular station are immediately noted and the instrument specialists are advised. Instruments are recalibrated after any repair before being returned to use. Because of the large number of monitoring locations and the distances involved, it is not practical to perform total system calibration on a more frequent basis. Again, because of the large number of monitoring locations that contribute data to the meteorological monitoring system, the temporary loss of data from one or two locations is not critical to the operation of the system as a whole. Even so, every attempt is made to keep the amount of downtime to a minimum.

In accordance with quality assurance requirements, PNNL maintains the procedures for calibration of all measurement and test equipment used by the Meteorological and Climatological Services Project. Primary, secondary, and traveling calibration standards are traceable through the Hanford Standards Laboratory to the National Institute of Standards and Technology. The procedures state that 2 mo before the expiration of calibration on any piece of equipment or instrument, a notice of instrument calibrations is generated that specifies the instrumentation scheduled for calibration. The notice is reviewed and signed by the instrument custodian (in this case the Meteorological and Climatological Services Project manager), authorizing the calibration of the equipment specified. On completion of calibration, a record of calibration is generated, and copies of the record are provided to the applicable instrument laboratory, the instrument custodian, and the PNNL Maintenance Services Department.

\section{Data Acquisition}

Data are acquired and processed at each monitoring station using a signal interface unit and a telemetry unit. Most of the signal interface and telemetry units are powered commercially; however, units at three sites $(7,8$, and 25$)$ are powered by batteries charged by solar panels. The signal interface unit acquires and processes the signals from the individual instruments, and the telemetry unit transmits the processed data to the HMS via a radio repeater on Rattlesnake Mountain. Inputs to the signal interface unit may be analog, counter, or digital. The unit scans its channels for information every $5 \mathrm{~s}$ (or every second for the tipping bucket rain gauge), stores the information for $15 \mathrm{~min}$, and sends the 15 -min-averaged values (made up of 180 samples) to the HMS. Values are transmitted on the hour and at 15 -min inter.vals. The output is a digital sequence of numbers transmitted at $416.5 \mathrm{MHZ}$ with $4 \mathrm{~W}$ of power.

The data transmitted from the remote monitoring stations are received at a base station located at the HMS and are sent to an International Business Machines (IBM) RISC System/6000 computer via an RS-232 serial data link.

\section{Atmospheric Transport and Diffusion}

Because the Hanford Site covers a large area with varying topographic characteristics, a meteorological monitoring system with a network of 29 remote stations and the HMS is used to estimate the meteorological conditions across the complex terrain of the site. 
Because of this varying terrain, use of a straight-line Gaussian model is not appropriate; instead, a trajectory model that treats atmospheric transport and diffusion as separate processes is used. An interactive Lagrangian puff dispersion model, MESOI Version 2.0 (NUREG/CR-3344, PNL-4753), was developed for use at the Hanford Site for estimating the transport and diffusion of effluents released to the atmosphere, and the Mesorad Dose Assessment Model (NUREG/CR-4000, PNL-5219) was developed for emergency response applications. Meteorological data (15-min averaged) are available on a network server that can be accessed by emergency response organizations to import data for their modeling needs.

\section{Quality Assurance}

Quality assurance for the Meteorological and Climatological Services Project is established and implemented by PNNL's formal quality assurance program, as contained in PNNL's Standards-Based Management System (PNNL 1997). The quality assurance program conforms to the requirements of DOE Order 5700.6C.

Independent surveillances and audits of the Meteorological and Climatological Services Project activities and procedures to ensure compliance with PNNL's Quality Management System and the project quality assurance plan are conducted by the PNNL Process Quality Department. These surveillances and audits can be initiated by the DOE-RL monitor, the PNNL program manager, the project manager, or the project quality engineer on either a routine and/or a random basis.

\section{Data Management}

Meteorological data from the monitoring network are collected, processed, and archived on an IBM RISC System $/ 6000$ computer system at the HMS. This system is a "nearly fault-tolerant" system, with dual central processing units and redundant mirrored disks. Incoming data are written to several independent hard disks on separate disk servers simultaneously, so that data are available even in the event of the failure of a disk or disk server. Each central processing unit also has a separate uninterruptible power supply in the event of a power outage. The operating system runs High Availability Clustered MultiProcessing (HACMPTM) software to help ensure that no single component or software failure will disable the system.

The Scientific Application, Visualization, and Initialization in Three Dimensions (savi3D ${ }^{\mathrm{TM}}$ ) environmental workbench commercial software is used for data management and display.

The 15-min-averaged data from the monitoring network are used as input to atmospheric transport and diffusion models for emergency response and are maintained for $10 \mathrm{~d}$ on the mainframe computer. At the beginning of the 11th day, the first day of the 15-min data is purged and 15-min data from the newly designated 10th day are stored.

savi3D is a registered trademark of Supercomputer Systems Engineering Services Company (SSESCO), Shoreview, Minnesota.

HACMP is a registered trademark of IBM, Austin, Texas. 
For permanent storage, the 15-min data are converted into hourly data. These data are processed daily using the ARCHIVE computer code (PNL-6279, Vol. 10). This computer program converts hourly binary meteorological data from the 10-, 60-, and 125-m towers into formatted (ASCII) data and organizes the converted data into appropriate monthly files.

At the beginning of every month, the monthly data on the IBM RISC System/6000 are processed prior to permanent storage. All data are reviewed using quality assurance computer programs (PNL-6279, Vol. 9). These programs check all data for the following types of potential errors:

- parameters out of range (e.g., January temperature $>16.7^{\circ} \mathrm{C}$ )

- unreasonable changes in parameter magnitude from one hour to the next (e.g., temperature change $\left.>5.6^{\circ} \mathrm{C}\right)$

- parameter conflict (e.g., visibility below a specific threshold value with no obstructing phenomena indicated [fog, snow, etc]).

These programs generate error listings that allow for the resolution of possible data irregularities. These computer-generated error listings are maintained on file; however, errors that can be readily resolved are corrected and archived. If they cannot be corrected, the data are indicated as "missing."

On completion of these monthly quality assurance checks, the final data are archived on multiple hard disks, and are available for additional processing (e.g., joint frequency distributions, wind roses, data summaries), as necessary.

\section{Exceptions}

No exceptions have been taken to should* statements in DOE/EH-0173T.

\section{References}

DOE/EH-0173T. 1991. Environmental Regulatory Guide for Radiological Effluent Monitoring and Environmental Surveillance. Assistant Secretary for Environment, Safety and Health, U.S. Department of Energy, Washington, D.C.

DOE Order 5400.1. "General Environmental Protection Program."

DOE Order 5700.6C. “Quality Assurance.”

NUREG/CR-3344, PNL-4753. 1983. MESOI Version 2.0: An Interactive Mesoscale Lagrangian Puff Dispersion Model with Deposition and Decay. J. V. Ramsdell, G. F. Athey, and C. S. Glantz, Pacific Northwest Laboratory for the U.S. Nuclear Regulatory Commission, Washington, D.C.

NUREG/CR-4000, PNL-5219. 1986. The Mesorad Dose Assessment Model. R. I. Scherpelz, T. J. Bander, G. F. Athey, and J. V. Ramsdell, Pacific Northwest Laboratory for the U.S. Nuclear Regulatory Commission, Washington, D.C. 
PNL-6279. 1989. Hanford Meteorological Station Computer Codes, Volume 9 - The Quality Assurance Computer Codes. K. W. Burk and G. L. Andrews, Pacific Northwest Laboratory, Richland, Washington.

PNL-6279. 1989. Hanford Meteorological Station Computer Codes, Volume 10 - The ARCHIVE Computer Code. G. L. Andrews and K. W. Burk, Pacific Northwest Laboratory, Richland, Washington.

PNL-6509. 1988. The Hanford Meteorological Data Collection System and Data Base. G. L. Andrews, Pacific Northwest Laboratory, Richland, Washington.

PNL-6684. 1988. The Data Collection Component of the Hanford Meteorology Monitoring Program. C. S. Glantz and M. M. Islam, Pacific Northwest Laboratory, Richland, Washington.

PNNL. 1997. "Subject Areas (Standards, Procedures and Guidelines), A-Manuals." In StandardsBased Management System [Online]. Available URL: http:/wwwi.pnl.gov:2080/.

PNNL-11471. 1997. Hanford Site Climatological Data Summary 1996, With Historical Data. D. J. Hoitink and K. W. Burk, Pacific Northwest National Laboratory, Richland, Washington.

PNNL-11472. 1997. Hanford Site Environmental Report for Calendar Year 1996. R. L. Dirkes and R. W. Hanf (eds.), Pacific Northwest National Laboratory, Richland, Washington. 


\section{Distribution}

No. of

Copies

\section{OFFSITE}

12 DOE/Office of Scientific and Technical Information

K. Campbell

Fish and Wildlife Service

U.S. Department of the Interior

P.O. Box 1157

Moses Lake, WA 98837

Confederated Tribes of the Umatilla Indian

Reservation

P.O. Box 638

Pendleton, OR 97801

Nez Perce Tribe

P.O. Box 365

Lapwai, ID 83540-0365

Oregon Department of Environmental Quality

811 SW Sixth Avenue

Portland, OR 97203

6 State of Washington Department of Health Division of Radiation Protection

P.O. Box 47827

Olympia, WA 98504-7827

Attn: A. W. Conklin (4)

D. McBaugh (2)

J. Stohr

State of Washington Department of Ecology

P.O. Box 47600

Olympia, WA $98504-7600$
No. of

Copies

A. Wallo III

Air, Water, and Radiation Division

Office of Environment

U.S. Department of Energy

1000 Independence Ave. S.W.

Washington, DC 20585

Yakama Indian Nation

Environmental Restoration

Waste Management Program

P.O. Box 151

Toppenish, WA 98948

\section{ONSITE}

12. DOE Richland Operations Office

G. M. Bell

A5-52

C. R. Briggs

A5-55

S. E. Clarke

A5-15

M. J. Furman

H0-12

J. B. Hall

R. D. Hildebrand

D. E. Olson

H. M. Rodriguez

K. M. Thompson

A5-15

$\mathrm{H} 0-12$

$\mathrm{H} 0-12$

A5-15

H0-12

A. C. Tortoso

H0-12

D. C. Ward

A5-15

Public Reading Room

H2-53

6 B\&W Hanford Company

T. A. Dillhoff

N2-57

K. A. Hadley

R3-56

G. J. LeBaron

S6-15

D. E. Rasmussen N1-47

J. R. Robertson T5-54

C. D. Wollam

R3-56 
DOE/RL 91-50

Rev. 2

No. of

Copies

10 Bechtel Hanford, Inc.

R. L. Biggerstaff

$\mathrm{H} 0-02$

K. R. Fecht

B. H. Ford

K. A. Gano

R. J. Landon

W. L. Pamplin

J. G. Woolard

J. P. Zoric

Environmental Restoration Program

Information Center (2)

\section{CH2M Hill Hanford}

E. T. Coenenburg

DE\&S Hanford, Inc.

D. J. Watson

4 DynCorp Tri-Cities Services, Inc.
B. J. Dixon
D. R. Herman
C. E. Marple
A. D. Poor

X3-79

G3-26

$\mathrm{S} 2-12$

S4-56

L6-55

4 Fluor Daniel Hanford, Inc.

W. D. Adair

H6-21

J. A. Bates

H6-23

K. A. Peterson

H6-23

L. K. Trent

H8-67

4 Lockheed Martin Hanford Corporation

G. M. Crummel

B. G. Erlandson

R1-51

P. C. Miller

R1-51

Central Files

R1-51

B1-07
No. of

Copies

2 State of Washington Department of Ecology
D. Teal
B5-18
N. Uziembo
B5-18

State of Washington Department of Health

J. W. Schmidt

B5-18

2 U.S. Environmental Protection Agency
L. E. Gadbois
B5-01
D. R. Sherwood
B5-01

3 Waste Management Federal Services, Inc., Northwest Operations

J. J. Dorian

H1-13

A. R. Johnson

H1-13

C. J. Perkins

H1-12

29 Waste Management Federal Services of Hanford, Inc.

R. J. Boom

T6-12

H. C. Boynton

T4-52

S. L. Brey

T6-12

L. P. Diediker (12)

H6-36

D. L. Flyckt

S6-71

T. P. Frazier

H6-25

D. W. Fritz

H6-36

B. P. Gleckler

H6-36

E. M. Greager

H6-36

J. J. Luke

D. L. Mitchell

H6-25

J. K. Perry

H6-29

D. L. Renberger

H6-25

R. W. Szelmeczka

T3-03

D. B. Van Leuven

L6.05

D. D. Volkman

H6-10

J. A. Winterhalder

T3-05

H6-21

M. T. Yasdick 
Rev. 2

No. of

Copies

34 Pacific Northwest Laboratory

\section{E. J. Antonio}

L. E. Bisping

W. J. Bjorklund

R. W. Bryce (10)
A. T. Cooper
P. E. Dresel
R. L. Dirkes
B. M. Gillespie
R. W. Hanf

$\mathrm{K} 3-54$

K6-75

P7-72

K6-91

K6-75

K6-96

K6-75

K6-75

K6-75
No. of

Copies

D. J. Hoitink

K9-30

V. G. Johnson

K6-96

K6-96

K6-75

K6-75

K6-96

K9-33

K6-81

P7-68

R. K. Woodruff

KI-06 